\title{
Debating Poverty Christian and Non-Christian Perspectives on the Social Question in Britain, 1880-1914
}

Dissertation

zur Erlangung des philosophischen Doktorgrades an der Philosophischen Fakultät der Georg-August-Universität Göttingen

vorgelegt von

Angelika Maser

aus München

Göttingen 2009 
1. Gutachter: Prof. Dr. Bernd Weisbrod

Seminar für Neuere und Neueste Geschichte Georg-August-Universität Göttingen

2. Gutachterin: Prof. Dr. Ilona Ostner Institut für Soziologie Georg-August-Universität Göttingen

3. Gutachter: Prof. Dr. Jan-Ottmar Hesse Institut für Wirtschafts- und Sozialgeschichte Georg-August-Universität Göttingen

Tag der mündlichen Prüfung: 04.08.2010 


\section{Eidesstattliche Erklärung}

Hiermit versichere ich an Eides statt, dass ich die eingereichte Dissertation „Debating Poverty. Christian and Non-Christian Perspectives on the Social Question in Britain, 1880-1914“ selbständig und ohne unerlaubte Hilfe verfasst habe. Anderer als der von mir angegebenen Hilfsmittel und Schriften habe ich mich nicht bedient. Alle wörtlich oder sinngemäß den Schriften anderer Autorinnen und Autoren entnommenen Stellen habe ich kenntlich gemacht. Die Abhandlung ist noch nicht veröffentlicht worden und noch nicht Gegenstand eines Promotionsverfahrens gewesen.

Angelika Maser

Göttingen, den 25.09.2009 


\section{Acknowledgements}

Like many doctoral theses, this one has taken a lot longer than planned. Along the way, many people have helped me with my work and supported me through difficult periods. To them it is owed that this study has finally become reality.

I started work on this thesis as a scholar at the graduate research group „The Future of the European Social Model“ (DFG-Graduiertenkolleg „Die Zukunft des Europäischen Sozialmodells“) at the Georg-August-Universität Göttingen. I would like to thank the German Research Foundation for the scholarship I received. I also benefitted from the lively discussions and friendly atmosphere within the research group and many of my fellow-graduate students have now become close friends.

My advisor, Prof. Dr. Bernd Weisbrod, accepted me as a $\mathrm{PhD}$ student and offered me the scholarship in the graduate research group without knowing me or my work and I am very grateful for his trust in me and for his readiness to embark with me on this undertaking. I am also very grateful to Prof. Jose Harris from St. Catherine's College, Oxford, for her advise and support and for making it possible for me to spend time at Oxford.

Lastly, I would like to mention the help I received from my father and my friends Kathrin and Tina who read through various parts of the thesis and gave valuable comments on them. My greatest thanks, however, go to my family and my friends - for bearing with me. 


\section{Table of Contents}

\section{Part I - The Setting}

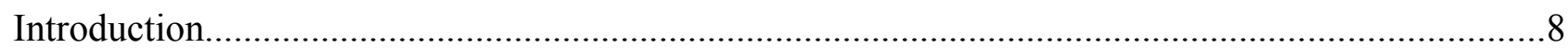

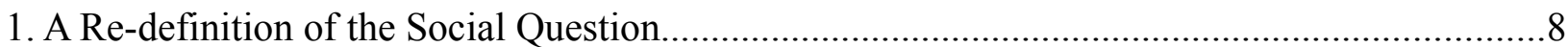

2. The Churches and their Roles in Modern Industrialised Society.........................................14

3. The Influence of Ideas and Values in Politics and the Role of Political Thought as Potential

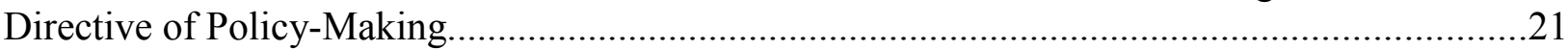

4. The Rise of Social Theology in Victorian Britain...............................................................30

5. Christian Socialism: A phenomenon of many shapes and variances.......................................35

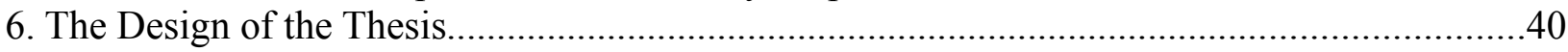

Chapter 1 - Some Aspects of the Intellectual Context of Late-Victorian and Early-Edwardian Social

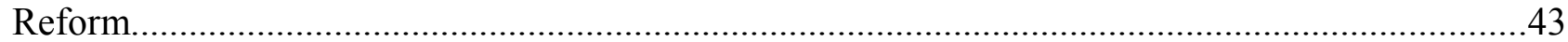

1. The Intellectual Context and the Contemporary Debate on Social Reform...........................43

2. The Political Setting: New Liberalism, Fabianism and the Rainbow Circle as Examples of the Institutionalised Progressive Movement......................................................................................54

\section{Part II - Debating Poverty: The Thinkers and their Arguments}

Chapter 2 - Stewart Duckworth Headlam and the Socialist Message of Christ ............................64

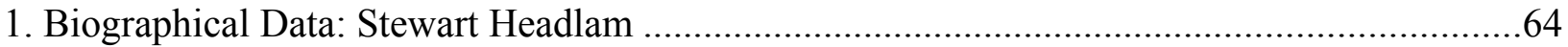

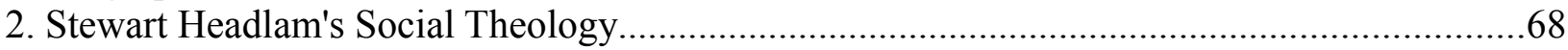

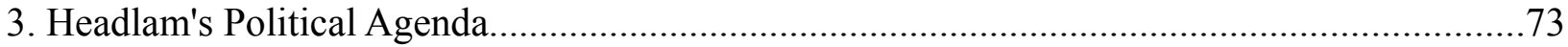

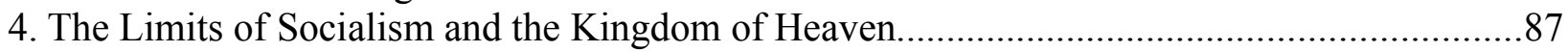

Chapter 3 - William Booth and In Darkest England.................................................................. 90

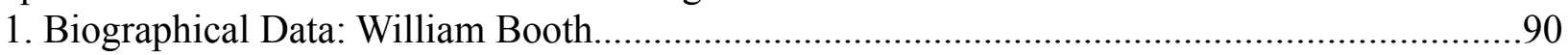

2. The Salvation Army: Caring for the Soul through the Body............................................... 92

3. In Darkest England and the Way Out: Booth's Social Scheme..........................................96

4. The Individual as Focal Point of Booth's Social Thought................................................102

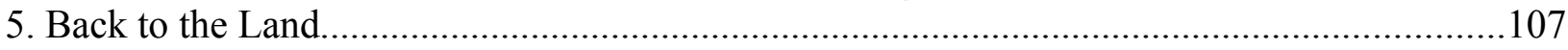

6. Education: An Essential in Social Reform.............................................................................113

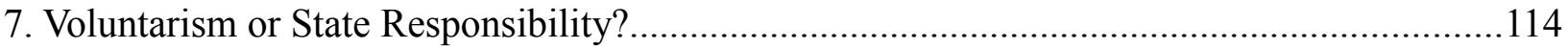

Chapter 4 - Henrietta Barnett and the Redeeming Powers of Community.....................................118

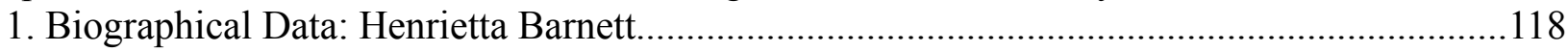

2. Barnett's Ideological Position: Between Individual Growth and National Wealth - Between

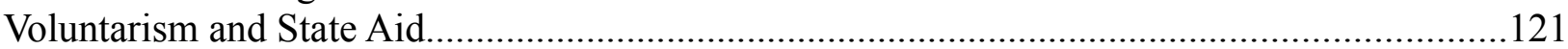

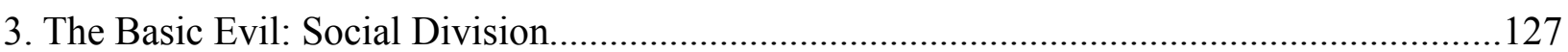

4. Towards Social Reform: The Magic Formula of Individuality in Community......................132

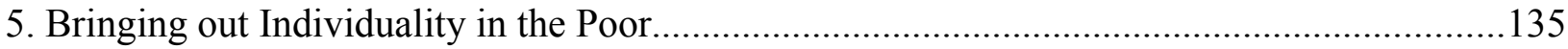

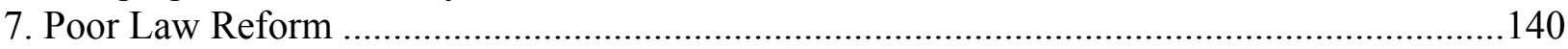

8. Housing as the Key to Social Salvation: Hampstead Garden Suburb..................................142 
Chapter 5 - Percy Alden and Poverty as a Complex National Question.....................................147

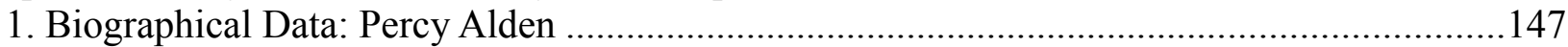

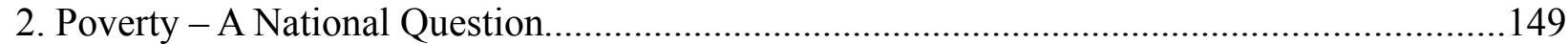

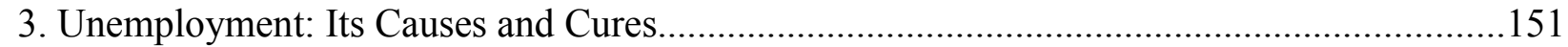

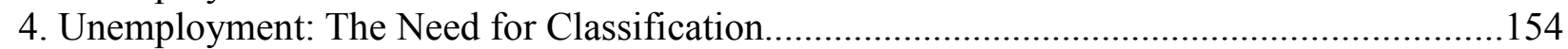

5. Housing: The National Repercussions of Destitute Housing................................................ 166

Chapter 6 - Clementina Black and Underpayment: The Root Evil of Modern Industrial Society...176

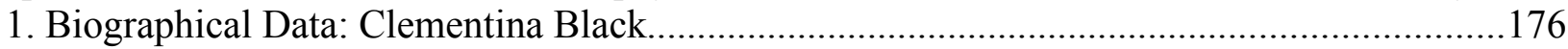

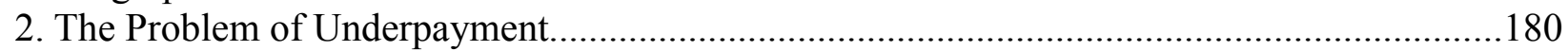

3. Some Mistaken Opinions on the Issue of Underpayment.....................................................183

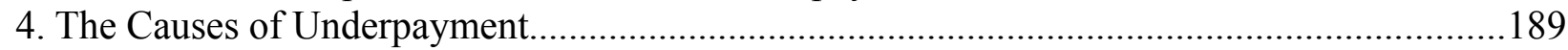

5. Alternative Models of Economic Organisation and Existing Checks Against Free Competition

6. The Costs to the Community and the Need for Collective Interference.................................195

7. Possible Solutions: Wage Boards and Courts of Arbitration..................................................200

Chapter 7 - Leo George Chiozza Money and the Error of Distribution........................................204

1. Biographical Data: Leo George Chiozza Money...............................................................204

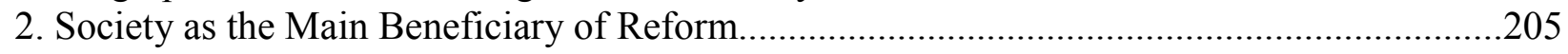

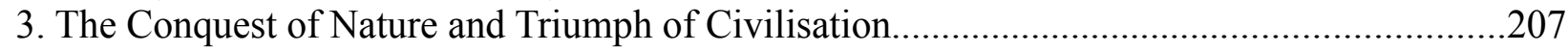

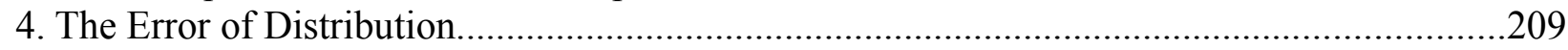

5. The Limits of Existent Checks on Unrestricted Competition and the Need for a Strong State

6. The State as Motor of Social Regeneration: Nationalisation and a State-Run Programme of

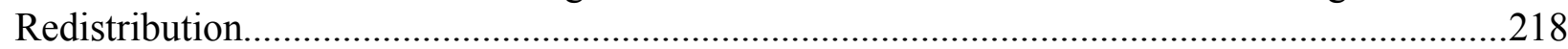

7. The Children: The Nation's Future ...........................................................................226

Chapter 8 - John Mackinnon Robertson on Social Progress ......................................................231

1. Biographical Data: John Mackinnon Robertson...............................................................231

2. The End of Human Evolution: Social and Cultural Growth..............................................234

3. Poverty and Social Fragmentation: The Double Bane of Civilisation..................................239

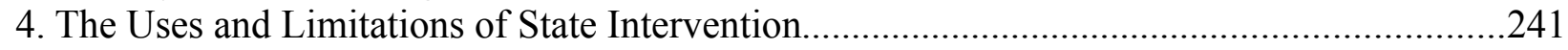

5. The Limits of State Intervention and the Need for Voluntary Action...................................250

6. Universal Suffrage as the Only Acceptable System in an Ideal State..................................258

\section{Part III - Conclusion and Outlook}

Chapter 9 - Conclusion.........................................................................................................262

1. Congruencies and Intersections in the Grievances Addressed and the Proposed Remedies for

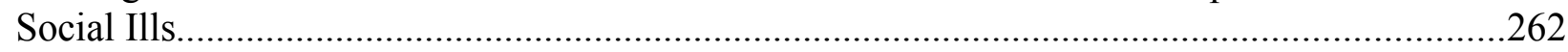

2. Voluntarism and State Help: A Carefully Negotiated Individual Balance.............................269

3. Individual versus Society: the Focal Points of Reform as Differentiator between Christian and

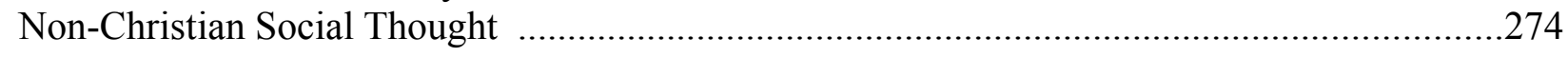

Outlook - Christian Socialism a Hundred Years On.............................................................283

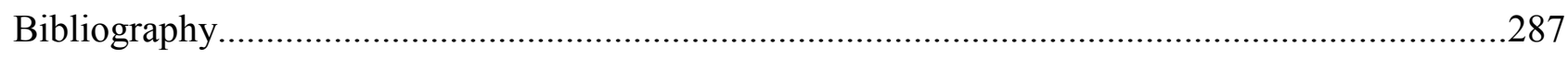




\section{Part I}

\section{The Setting}




\section{Introduction}

\section{A Re-definition of the Social Question}

In the second half of the nineteenth century, Britain saw a re-definition of the social question. The established system of poor relief based on self-help and private philanthropy as the main pillars, and on the New Poor Law of 1834 with its principle of Less Eligibility as a last resort, showed more and more holes and insufficiencies. The concurrent processes of industrialisation and urbanisation in the first half of the century had produced clusters of poverty, especially in the cities. The dirt, squalor and stink of slum neighbourhoods and the ugliness of overcrowded districts brought home to the nation very forcefully the reality and extent of the problem of poverty ${ }^{1}$. With the exodus from the rural village and the transition from small workshops to large-scale production in factories, traditional social networks in the family, village community or at the workplace had largely broken down. Support of the needy fell increasingly to the local authorities which, in certain districts, proved an inordinate financial and administrative burden. The unequal strain on local bodies also called into question the Poor Law principle of National Uniformity. The waves of mass unemployment in the wake of the alleged Great Depression of the 1870s and 80s contributed to the growing public unease. The experience of myriads of working men and women losing their jobs due to fluctuations in international trade cast doubt on the idea of poverty as a personal moral failure. It shook the liberal credo that the economy if left alone worked to everyone's greatest advantage and that in a free market economy everyone could strive if only they put in the effort.

The social and political system was out of joints, a development which shook up the middle and upper strata of Victorian society. Historians agree that compared to continental Europe, the threat of a violent social upheaval was relatively low in Britain. But fear of such unrest was nonetheless very real among contemporaries. The first half of the nineteenth century saw a series of challenges to the political and social establishment. Local and national disturbances such as the Peterloo massacre of 1819, Captain Swing (1830) and the rise of Chartism between 1838 and 1848 illustrated the disruptive potential of working class protest and raked the fears of the better-off ${ }^{2}$. The Trafalgar Square riots of 1848 when demonstrators and police put up a fight which resulted in smashed

Hunt, Tristram, Building Jerusalem: the rise and fall of the Victorian city, 2004

Harris, Bernard, The origins of the British welfare state, 2004, p.31f 
windows and ransacked shops along Pall Mall provoked much outrage in the press. The incident foreshadowed the "Socialist riots" of the 1880s, also on Trafalgar Square, which culminated in Bloody Sunday of $1887^{3}$. Fear of the violent and revolutionary potential of the working classes was reinforced among the socially higher strata of mid- and late-Victorian society through the franchise reforms of 1867 and 1884. The Reform Acts gave the vote to a considerable section of male workers equipping, as many feared, the ignorant and uncultured with the legal means to overturn the political establishment ${ }^{4}$.

The fear of upheaval was accompanied by an increasing moral outrage at the existence of abject poverty and destitution in the midst of a civilised and prosperous country like Great Britain. Since the 1830s, Charles Dickens had in his serialised novels brought before the public eye the suffering caused by poverty and destitution in highly memorable and touching form 5 . In 1849, Henry Mayhew launched his series of articles on the living conditions of the London poor for the Morning Chronicle. Mayhew ventured into the poorest districts of the metropolis to interview flower girls, street sweeps, prostitutes and petty criminals and his articles, compiled in 1851 as London Labour and the London Poor, gave authentic accounts of the daily lives of the poor in their own language. The greatest impact, however, probably had Andrew Mearns' The Bitter Cry of Outcast London: An Inquiry into the Conditions of the Abject Poor, published in 1883. His findings did not vary greatly from conditions described by Dickens or Mayhew. But the pamphlet was reprinted in parts and cleverly reviewed by W. T. Stead in the Pall Mall Gazette and thereby given a very wide publicity. Mearns shocked his readers with vivid descriptions of immorality and vice fostered by poverty and want.

In a less sensationalist vein, some of the early scientific investigations into social questions authenticated many aspects of the picture so lividly painted by writers such as Dickens, Mayhew and Mearns. The 1880s saw the beginnings of Charles Booth's first concerted social study of London. He published his first book Life and Labour of the People ${ }^{6}$ in 1889. In it, he showed that thirty-five percent of the population of London lived on or below a relatively low poverty line of about $20 \mathrm{~s}$ a week for a family of five. His results were confirmed a decade later when Benjamin Seebohm Rowntree conducted a similar door-to-door inquiry for York in Poverty: A Study in Town $\mathrm{Life}^{7}$. All of these factors helped to call into question traditional assumptions about the nature and causes of poverty, and the solution to the social problem and facilitated the emergence of a new order of social support.

Laybourn, Keith, The rise of socialism in Britain, 1997, p.12f

See e.g. Jones, H. Stuart, Victorian political thought, 2000, p.63ff

See e.g. Pritchard, Ron E., Dickens's England, 2002; Lenard, Mary, Preaching pity, 1999

Booth, Charles, Life and labour of the people in London, 1892

Rowntree, Benjamin Seebohm, Poverty: a study in town life, 1901 
The newly developing social regime rested upon three main pillars; one of them, and an important pier also of the old system, was a reformed system of charity. The New Poor Law of 1834 had always been supplemented by lavish amounts of private philanthropy, leaving the authorities to deal only with the very destitute. The Charity Commissioners of London estimated that in 1875, the income of charities in the metropolis ran to more than $£ 2 \mathrm{~m}$; their estimate included only about three quarters of London charities and excluded church-based funds ${ }^{8}$. Poor Law authorities paid out about the same sum to paupers in the course of that year. But the enormity of the problem of poverty in industrial cities brought out the disadvantages of a system which relied so heavily on private initiative. Critics pointed out the patchwork character of private philanthropy, its indiscriminate giving, its arbitrary nature and the failure to keep proper records and exchange information. They complained that the system invited fraud and sunk large amounts of money in the vast pool of poverty without appreciable results. Worse still, they argued, such a system undermined the networks of mutual aid and self-help among the poor and ultimately only aggravated the problem of pauperism.

Some private philanthropic endeavours therefore began to dispense with alms-giving and developed a more systematic approach to the alleviation of poverty. To counteract the excesses of overcrowding and unsanitary living in the East End, for instance, Octavia Hill ventured into her pioneering housing reform project at Paradise Place. With the financial support of John Ruskin, she acquired three tenements there in 1864 which she rented out as two- or three-room dwellings to poor families at affordable prices ${ }^{9}$. Hill believed that life in the overcrowded, dirty slum neighbourhoods of the metropolis was physically and morally corrupting. She placed great emphasis on sanitary and safe living conditions, putting most of the profits derived from already moderately low rents back into improvements. In order to fight the morally detrimental effects of slum life, she accompanied the provision of sound tenements with a rigorous visiting programme, designed to foster cleanliness and respectability among her tenants, to offer advise and help in practical questions and to encourage relations between neighbours within the buildings. At the time of her death, her enterprise managed approximately 6.000 such dwellings. Another example of a systematic effort to fight the suffering of the poor was Dr. Thomas Barnardo's work for the destitute children of London. Touched by the plight of homeless youngsters, he established children's homes and orphanages, offering a decent place to live as well as an education in order to give the children a chance on the labour market ${ }^{10}$. By the beginning of the twentieth century, there existed over one

\footnotetext{
McBriar, Alan M., An Edwardian mixed doubles, 1987, p.41

9 Octavia Hill (1838 - 1912), housing reformer. Hill, a close friend and collaborator of John Ruskin, was a moving force behind the development of social housing, including Council Housing, and an instigator behind the establishment of the National Trust. She was a member of the Royal Commission on the Poor Laws set up in 1905.

10 Thomas John Barnardo (1845 - 1905). Barnardo studied medicine at the London Hospital, initially to enter medical
} 
hundred Barnardo homes throughout the country.

The best-known instance of the new "scientific" and concerted approach at social reform is probably the formation of the Charity Organisation Society (COS). Founded in 1869 under the leadership of the philosopher, social agitator and university don Bernard Bosanquet and his wife Helen $^{11}$, it aimed to rectify some of the worst failings of private charity by organising and coordinating philanthropic bodies so as to make the best possible use of resources. The COS cultivated a case-study approach, investigating into the nature, causes and effects of an individual's poverty. The method ran counter to the indiscriminate almsgiving of traditional philanthropy and was designed to cut at the very roots of poverty instead of just treating its symptoms. With its work, the Charity Organisation Society aimed at fostering the virtues of thrift, prudence and self-help. Its benefits were meant to empower the individual to return to independence. The down-side of the method was the unfortunate distinction into deserving and undeserving poor which was meant to help the Charity Organisation Society to employ available resources to the most visible advantage ${ }^{12}$, but which has exposed the organisation to much abuse and criticism from both contemporaries as well as historians.

Despite the scepticism of the Charity Organisation Society as to the moral righteousness and will to independence of large sections of the so-called undeserving poor, self-help and mutual aid organisations, too, sprang up in the period in question. They formed arguably the strongest pillar of the welfare system before the First World War $^{13}$. Although no statistical data is available on the subject for obvious reasons, neighbourhood support and help from family members probably constituted the largest source of relief in situations of distress among the working classes ${ }^{14}$. Frank Prochaska among others has shown how working class women took over the care for the elderly and the sick, and how neighbours shared material possessions or offered help with nursing and child care. Mutual aid organisations such as burial societies, deposit societies and dividing societies offered a variety of benefits and services such as sick pay or small premiums payable upon a member's death for a small weekly contribution.

The enormous impetus among the working classes towards self-help and mutual aid is illustrated,

missionary work with the China Inland Mission. When he became aware of the misery and destitution among the homeless children and youths who camped out in the vicinity of the London Hospital, he turned to relief work at home. He opened his first home for destitute children in 1870. By the time of his death, there existed 112 such homes throughout the United Kingdom.

11 Bernard Bosanquet (1848 - 1923), philosopher and social reformer. Bosanquet was a leading exponent of English Idealism. He came to quite different conclusions in the application of Idealism to social questions than did his erstwhile mentor T. H. Green. With his wife Helen Bosanquet $(1860-1926)$, he became leader and chief political theorist of the Charity Organisation Society.

12 McBriar, Alan M., An Edwardian mixed doubles, 1987, p.54-85

13 See e.g. Prochaska, Frank K., The voluntary impulse: philanthropy in modern Britain, 1988

14 Prochaska, Frank K., The voluntary impulse: philanthropy in modern Britain, 1988 
for instance, by the phenomenal growth rate of friendly societies throughout the nineteenth century. Two of the largest and oldest societies, the Manchester Unity of Oddfellows and the Ancient Order of Foresters, grew from roughly 225.000 and 80.000 members respectively in 1850 to 713.000 and 666.000 members in $1899^{15}$. In 1912, membership in friendly societies ranged at over seven million men and women, collecting societies sported another roughly eight million members. Historians have estimated that up to seventy five percent of adult males in Britain belonged to a mutual aid organisation on the eve of the First World War $^{16}$. Alongside friendly and other mutual support societies, co-operative stores sprang up in the period in question. They, too, served some families as a means to subsidize their meagre incomes. The fees payable upon joining a co-operative society, however, tended to make them mostly suitable for the slightly better-off among the working population.

Another important element of self-help and mutual aid was trade unionism. The stormy history of unionism, especially towards the end of the century, mirrors some of the difficulties encountered by reformers and legislators in their attempt to re-define the social question and to improve the conditions of the toiling masses. The old unions of the pre-1850s had operated very much along the lines of trade-specific friendly societies and many unions continued to do so in the second half of the nineteenth century. Parliamentary papers for the year 1914 show that out of a total expenditure of $£ 4.2 \mathrm{~m}$ the roughly 700 trade unions on register paid about $£ 680.000$ in sickness and accident benefits and another $£ 540.000$ in superannuation payments and grants to members. Including the trade union-specific payments of strike money and unemployed insurance, the percentage of expenditure on benefits of the total expenditure was 66 percent $^{17}$.

But the 1880s saw a radicalisation of unionism. Some trade unions, the so-called new unions, acquired a political dimension and became the subject of public dispute. In addition to their function as trade specific friendly societies, the new unions aimed to give to the working classes a voice in politics. They considered themselves vehicles of labour emancipation. The Bryant and May strike of 1888 and the London Dock strike of the following year bear witness to the increasing militancy among certain groups of trade unionists and their readiness to fight for better living and working conditions. Many of the early labour leaders, among them James Keir Hardie, Ben Tillett, John Burns and Tom Mann, rose to their positions through union activity. Trade unions provided the working classes with their first representatives in Parliament by co-funding the early Lib-Lab candidates. But although hailed by some reformers as the epitome of self-help and working class

15 Hopkins, Eric, Working class self-help in nineteenth-century England, 1995, p.9-70

16 Harris, Bernard, The origins of the British welfare state, 2004, p.81ff; see also Gorsky, Martin, Patterns of philanthropy: charity and society in nineteenth century Bristol, 1999

17 Harris, Bernard, The origins of the British welfare state, 2004, p.86 
emancipation, trade unionism stood on shaky legal foundations. The Trade Unions Act of 1871 had legalised them, but the Criminal Law Amendment Act of the same year condemned picketing as illegal. Most famously, with the Taff Vale decision of 1901, unions were made liable for damages incurred by strike action ${ }^{18}$.

Alongside the re-organisation of private charity and the growth of formalised self-help grew an increasingly interventionist state as a third pillar of the new welfare system. At first, legislation was scattered, designed to patch up holes in the system or to curtail the worst excesses of an industrialised laissez-faire economy ${ }^{19}$. The earliest moves towards a more interventionist state happened in the area of factory legislation. With the Factory Act of 1833, the government assumed some degree of responsibility for working conditions and established the first independent factory inspectorate in the notoriously unhealthy textile trades. The Ten Hours Act of 1847 limited working hours in textile mills for women and adolescents. The Factory Acts of 1864 and 1878 bear witness to an increasingly confident government as a legislator on social issues. They introduced detailed standards of sanitation in factories and workshops, prescribing ventilation, an average temperature and certain safeguards to the workers' health. Public health with its various facets, too, increasingly came into the focus of governmental action. The Public Health Act of 1848 introduced a General Board of Health. The Sanitary Act of 1866 established compulsory enquiries into sanitary conditions in districts where the death rate was extraordinarily high.

With the Common Lodging Houses Act and the Labouring Classes Lodging Houses Act of 1851, the government began tackling the problem of housing. The Acts empowered the municipalities to build accommodation for the poorest strata of society. The Artizans' and Labourers' Dwelling Acts of 1868 and 1875 gave local authorities the power to demolish unsanitary houses and to draw up improvement schemes. In the area of education, a favourite field of action for private bodies, government intervention started relatively late. The 1870 Forster Education Act set out to fill the gaps in the extant system of elementary education which was provided by voluntary agencies and religious bodies. The Elementary Education Act of 1880 introduced compulsory attendance at elementary school for children aged five to ten. Although education was not yet provided for free, by 1891 most elementary school children were exempted from school fees on account of the low incomes of their parents.

The increasing responsibilities assumed by state and municipalities for their citizens with regard to health, housing and education bear witness to the changing conceptions of poverty and its causes and also, in turn, helped to facilitate and to accelerate the public re-thinking on the social question.

Hopkins, Eric, Working class self-help in nineteenth-century England, 1995, p. 73-182

19 Harris, Bernard, The origins of the British welfare state, 2004, see esp. Chapter 3 and Chapters 7-10 


\title{
2. The Churches and their Roles in Modern Industrialised Society
}

\author{
a) A Victorian Crisis of Faith?
}

In this changing world of welfare needs and welfare provisions, the churches in keeping with their century-old traditions continued to play an important part as providers of support. The religious landscape in Britain at the time was dominated by Anglicanism and Nonconformity. Among the Christian denominations, the religious census of 1851 showed 51 percent of the British churchgoing population to be members of the Church of England. 44 percent went to services at dissenting sects and four percent, mainly the Irish working class immigrants who clustered in the cities along the West Coast, were Roman Catholic. There existed a growing Jewish minority of about 0.2 percent of the religious population in Britain in $1851^{20}$. The influx of Russian refugees from the 1860s onwards strengthened the Jewish communities in big industrial cities like London and Manchester. Islam had not yet begun to make a significant impact upon the religious landscape in Britain. The percentage of Muslims, together with adherents to all other religious faiths, took up the small proportion of 0.8 percent of the population.

There is some debate on the health of churches and chapels at the time under scrutiny in this study ${ }^{21}$. Some historians have argued that in the wake of the Enlightenment and under the influence of industrialisation and its accompanying social changes, church and chapel lost their significance and gave way to the secularised society of modernity. Influential research in the 1960s and 1970s made out a crisis of faith in Victorian England, a view very much en vogue also among contemporaries during the nineteenth century. The argument about the crisis takes into account various aspects of established religion. Some historians such as Alan Gilbert or Robert Currie ${ }^{22}$ detected a sharp drop in attendance figures at Sunday service among Anglicans and Nonconformists and used data gathered in the religious census of $1851,1886 / 7$ and 1902/3 as well as parish records and local surveys to argue that the age of industrialisation was accompanied by a process of secularisation. In their interpretation, only Roman Catholicism continued to enjoy relative strength, in part because among the predominantly Irish congregations religious affiliation was linked to issues of national and cultural identity. Others, such as Bernard Lightman, emphasised the challenges to established dogma by the recent boom in the natural sciences and moral sentiment. All of them cast doubt on a

\footnotetext{
20 McLeod, Hugh, Religion and society in England, 1850 - 1914, 1996; for a discussion of these figures see esp. Chapter One "Patterns of Religious Belonging"

21 For a good overview, see e. g. McLeod, Hugh, Religion and the working class in nineteenth-century Britain, 1996

22 Currie, Robert and Alan D. Gilbert, Religion, 1972
} 
literal interpretation of Scripture and traditional Christian doctrine and helped to alienate an increasingly educated populace from established orthodox religion, they argue. ${ }^{23}$

More recent research has helped to paint a more balanced picture of the situation of institutionalised Christianity in turn-of-the-century Britain. New approaches to the question of the failing or continued health of churches and chapels in the Victorian period have unearthed evidence to suggest that not only were there considerable variations in the decline of outward signs of formal religion among Anglicans and Nonconformists, but that religious belief and private religious practice remained strong. The unilinear interpretation of church attendance figures has been called into question by local studies. Contrary to interpretations offered by advocates of the secularisation theory, some parish records suggest a rise in attendance figures in certain periods, for instance figures for Anglican middle class parishes quoted by Robert Currie for the period 1901 to $1912^{24}$. There were denominational variations, too. Particularly the new Nonconformist denominations such as the Salvation Army and the Churches of Christ experienced phenomenal growth during the decades around the turn of the century. Jeffrey Cox in a study of churches and chapels in the district of Lambeth between 1880 and 1914 has shown that while attendance at Sunday services did indeed drop in the area, special services such as Christmas and Easter services or watch night services to celebrate the new year still drew crowds. Rites of passage, too, continued to be celebrated by the people ${ }^{25}$. Cox showed that many who did not attend Sunday worship attached great importance to christenings and motherings.

The steadily growing attendance figures at Sunday schools throughout the second half of the nineteenth century also call into question the argument on a universal crisis of faith. The historian $\mathrm{J}$. N. Morris counted over 5000 attendees at Sunday School out of a total figure of just above 10.000 registered members of a church or chapel between the ages of five and fifteen in the small urbanity of Croydon in $1867^{26}$. Cox cites figures which indicate a continuing popularity of Sunday schools in Lambeth even after the Forster Education Act of $1870^{27}$. Cox questioned the idea of an intellectual or moral secularisation of British society in the Victorian and Edwardian period. He claimed that the working classes, the social group allegedly most alienated from church and faith, did not sway towards indifference or heathenism, but held an intricate set of beliefs derived from orthodox

\footnotetext{
23 Lightman, Bernard, The origins of agnosticism: Victorian unbelief and the limits of knowledge, 1987; Lightman, Bernard V., Robert Elsmere and the Agnostic Crisis of Faith, 1990; McLeod, Hugh, Religion and irreligion in Victorian England, 1993

24 Currie, Robert; Gilbert, Alan D. and Lee Horsley, Churches and churchgoers: patterns of church growth in the British Isles since 1700, 1977

25 Cox, Jeffrey, The English churches in a secular society, 1982; see esp. Chapter Four "Diffusive Christianity and the Churchgoing Nation"

26 Morris, Jeremy N., Religion and urban change: Croydon 1840-1914, 1992, p.57

27 Cox, Jeffrey, The English churches in a secular society, 1982, p.81
} 
Christianity, folklore and custom which Cox termed "diffusive Christianity"28. Sarah Williams supported and expanded Cox's argument in a study of religion and irreligion in the London district of Southwark. She showed that belief in Christian doctrine and rites such as weddings and christenings coexisted alongside popular superstitious beliefs and semi-magical practices ${ }^{29}$. Hugh McLeod argued that despite the decline of formal church attendance, in culture and outlook, Britain remained an essentially Christian country ${ }^{30}$.

The argument that churches and chapels lost their social significance in the wake of industrialisation can thus on closer inspection not be verified.

b) Religious Bodies as providers of welfare

Without doubt, religious institutions of all denominations continued to play a paramount role in British society as providers of welfare. Jeffrey Cox has stressed the important social function of the churches and chapels in his study of Lambeth. He found hardly a congregation or parish in the poor neighbourhoods which did not offer provident clubs, boot, blanket or coal clubs, lantern lectures, Bands of Hope or soup kitchens ${ }^{31}$. For the years 1899 and 1900, Cox counted fifty-eight church- or chapel-based thrift, slate and friendly societies, thirty-six literary and debating clubs and thirteen adult vocational classes in the four districts of Lambeth ${ }^{32}$. Mothers' meetings, or maternity classes, proved particularly successful. Cox found fifty-seven such meetings among the religious establishments of Lambeth around the turn of the century. Urban missions of all denominations which sprang up during the $1850 \mathrm{~s}$ and $60 \mathrm{~s}$ in the poor neighbourhoods of industrial towns provided similar services as part of their endeavours to cater for the needs of the working classes.

How should such social work on the part of religious bodies be appraised? The historian Edward Norman has insinuated that the churches undertook their social endeavours mainly out of selfinterest, trying to keep and win old and new members among the lower social strata. He has pointed out that by providing for the worldly needs of their parishioners, the local clergy did nothing but fulfil their vocational duties as they had been defined for centuries. ${ }^{33}$ It is true that there was nothing particularly revolutionary about coal and blanket clubs or the cheap dinners given out by parish

\footnotetext{
28 Cox, Jeffrey, The English churches in a secular society, 1982, p.97

29 Williams, Sarah Charlotte, Religious belief and popular culture: a study of the South London Borough of Southwark c1880-1939, 1993, p.10

30 McLeod, Hugh, Religion and society in England, 1850 - 1914, 1996

31 Cox, Jeffrey, The English churches in a secular society, 1982, p.58ff

Cox, Jeffrey, The English churches in a secular society, 1982, p.58

33 Norman, Edward R., Church and society in England, 1770-1970: a historical study, 1976; see esp. Introduction
} 
institutions. Very often, their aim was quietist, alleviating the immediate suffering of individuals in a dual attempt to back up the existing social order and to tie the lower classes to the $\operatorname{church}^{34}$. Nonetheless, philanthropic activities on the parish level changed gradually in order to meet the new challenges of industrial society and to target the evils of urban overcrowding and rural decay.

The vested interests of religious bodies and their commitment to social work can not easily be segregated. Their attempts at as well as their motives for relieving the suffering of the poor were varied and inventive. Frank Prochaska has shown how the ever-popular mothers' meetings acquired a reformatory tang when they metamorphosed from prayer meetings into expert lectures on childrearing, hygiene, domestic economy, healthy cooking or the current prices on the housing market, all of it glossed over, for the sake of respectability, with Bible readings and needle work ${ }^{35}$. The newly emerging boys' clubs such as the Anglican Cyprus Boys' Club in the parish of St. John the Divine, Kennington, not only kept working lads off the streets, but provided them with newspapers, journals and books for personal education, with lectures and discussion groups for intellectual stimulation, gyms and regular weekend outings to the countryside for physical recovery and personal development ${ }^{36}$.

The most significant contribution which organized religion made to relieving the ills of society from the late eighteenth well into the twentieth century, it has been argued, were visiting programmes ${ }^{37}$. District visitors assisted the poor with domestic advice, practical help in child care and hygiene, material gifts and spiritual edification all delivered through friendship and personal example. The earliest visiting society was the Methodist Benevolent or Stranger's Friend Society, founded in 1785. The Church of England sported 47.112 district visitors in 12.000 out of its 15.000 parishes in 1889. Nursing started as a natural outgrowth and logical continuation of the idea of district visiting and missionary work among the poor. It, too, became a favourite service supplied by religious institutions ${ }^{38}$. Anglican sisterhoods in particular played an important role in the field of nursing. Among the ten earliest sisterhoods, nine were devoted exclusively or partially to nursing ${ }^{39}$. The Nursing Sisters of St. John the Divine, for instance, staffed King's College Hospital. The nondenominational London Bible and Domestic Mission founded by Ellen Ranyard in 1857 employed the first trained full-time district nurses in London, the so-called Bible Nurses. The Bible Nurses cooperated with municipal authorities. From 1899, they took over the nursing care for school children in state-funded schools in London. When in 1912 the London County Council opened the

\footnotetext{
Vicinus, Martha, Independent women, 1985, p.81

Prochaska Frank K., A mother's country: mothers' meetings and family welfare in Britain, 1850-1950, 1989

6 Eagar, Waldo McGillycuddy, Making men, 1953, p.170ff

37 Prochaska, Frank K., Christianity and social service in modern Britain: the disinherited spirit, 2006, p.61ff.

38 Prochaska, Frank K., Body and Soul: Bible Nurses and the Poor in Victorian London, 1987

39 Mumm, Susan, Stolen daughters, virgin mothers, 1999, p.114
} 
Minor Ailment Centres, they employed Bible Nurses to run the centres.

Roman Catholic and Jewish bodies, too, made important contributions to the new network of welfare provisions. Some offered their services to the public at large, but others aimed specifically at members of their own faith. Nursing was a service pioneered by Roman Catholic sisterhoods. The French Order of the Daughters of Charity had spread to Britain at the beginning of the nineteenth century and made a name for itself through its nursing activities in the slums of the industrial cities. The Irish Roman Catholic Sisters of Mercy provided nursing services to members of their own faith as well as others since 1827. By contrast, the Associated Catholic Charities, founded in 1811, made it their task to clothe, educate and apprentice the children of the Roman Catholic Poor exclusively. The Catholic Poor Schools Committee was founded in 1847 to rectify the lack of religious-based instruction among the British Roman Catholics. The St. Joseph's almshouses provided alternatives to the workhouse for members of the Roman faith ${ }^{40}$.

Alternative provisions to extant state-run or philanthropic institutions were especially important to members of the Jewish faith, as workhouses made no provisions for kosher food or shabbath observance and usually lacked a suitable prayer room. Manchester Jewry, the largest provincial Jewish community in Britain, established a Board of Guardians in 1867, financed by the local Jewish congregations and private subscribers, which provided material, financial and medical support to practising Jews. They also offered relief which addressed needs particular to the Jewish religion such as payments to the family of a deceased during Shiva or passover relief payments. Jewish autarchy in welfare provisions was, however, not absolute. The Jewish community in Manchester, for instance, negotiated special terms with the workhouse to ensure that paupers who could not be helped by the Board of Guardians would be allowed to abstain from work on Shabbath and religious holidays ${ }^{41}$.

c) Methodism and the Labour Movement

Another respect in which institutionalised religion contributed to the re-shaping of the social and political landscape of Victorian and Edwardian Britain was through its impact on the labour movement. Especially the more plebeian Nonconformist denominations supposedly left their marks on the labour movement. The historian Robert Pope described how in the mining communities of

\footnotetext{
40 For more information on Roman Catholic social endeavours see e. g. Walsh, Barbara Mary, A social history of Roman Catholic nuns and sisters in nineteenth and early twentieth-century England and Wales: the veiled dynamic, 1999; Walsh, Barbara, Roman Catholic nuns in England and Wales, 1800-1937: a social history, 2002; Macclelland, Vincent Alan, English Roman Catholics and higher education, 1830-1903, 1973

41 Liedtke, Rainer, Jewish welfare in Hamburg and Manchester, c.1850-1914, 1998, p.104
} 
South Wales, the Nonconformist chapels became centres of pro-labour propaganda ${ }^{42}$. Keir Hardie, returned to Parliament in 1900 by the people of Merthyr and Aberdare, was among the first and most influential preachers cum social agitators in South Wales who clothed their socialist message in religious garb and thus made it both accessible and acceptable to the Welsh miner whose life was permeated by chapel culture. Keir Hardie made use of chapels and congregational meeting rooms for his political speeches and thus embedded his social message in a religious context. Pope lists a number of Welsh laymen and preachers, among them Rhondda Williams, co-instigator of the New Theology Movement of 1907, who followed Hardie's example and mixed social and political elements into their religious addresses.

The Labour politician Morgan Phillips has proclaimed famously that trade unionism owed more to Methodism than to Marx. This line of argument was taken up, among others, by the historians Robert F. Wearmouth and E. P. Thompson ${ }^{43}$. They conjectured that the experience gathered as part of self-organised and self-funded Primitive Methodist congregations helped to equip individual working men with skills such as literacy, public speaking and organisational capacity which they could turn to excellent use as leaders of local and national unionism. Thompson argued that the more plebeian forms of Methodism among other influences "diffused a general addiction to the forms and properties of organisational constitutionalism"44 which supposedly helped to explain the ease and frequency with which working men combined in self-help and mutual support associations throughout the late eighteenth and nineteenth centuries. He also held Methodism responsible for the growth of self-respect and independence among the working classes which preconditioned the rise of a concerted labour movement ${ }^{45}$.

A recent article on the mining villages of South Northumberland by the historian Winifred Stokes supports the argument in so far as it finds the number of Methodist union leaders in the area to have been quite out of proportion with the actual figure of Methodists in the region ${ }^{46}$. Stokes does, however, argue that there were more complex forces at play, an argument she illustrates with the example of the return to Parliament in 1874 of the Methodist labour leader Thomas Burt for Morpeth. His personal experience of helplessness in the face of his employers', the mine owners', deliberateness, she argued, as well as his outrage about the dangerous working conditions and low pay in the mines played as much a part in his political involvement as did his Methodist associations. Two studies of the Yorkshire coal mines and agricultural labourers in East Anglia

\footnotetext{
42 Pope, Robert, Building Jerusalem: nonconformity, labour and the social question in Wales, 1906-1939, 1998

43 Thompson, Edward Palmer, The Making of the English Working Class, 1963; Wearmouth, Robert F., Methodism and the trade unions, 1959

44 Thompson, Edward Palmer, The Making of the English Working Class, 1963, p.673

45 Thompson, Edward Palmer, The Making of the English Working Class, 1963, p.397ff

46 Stokes, Winifred, Politics, Pitmen and Primitive Methodism in the South, 2001, pp.18-28
} 
corroborate a general connection between Methodism and the trade union movement, but also point to the impact of substantial variations in social and religious composition on the relationship. Thus, while in the predominantly Nonconformist Yorkshire coal fields, the levelling culture of the chapel and the paternalist structure of employment de-radicalised labour leaders, prevented explicitly classbased labour agitation and led to continuing support of a Lib-Lab solution, in the agricultural areas of East Anglia, the Nonconformist working classes faced a prevailingly Anglican employing class. Here, the religious differences served to exacerbate social grievances, radicalising labour leaders and leading to a support of the newly forming Labour movement ${ }^{47}$. Nigel Scotland has shown how in this environment, Methodist organisation "provided a model for agricultural union organisation and strategy, while Methodist buildings provided a home for quite a number of union meetings ${ }^{\text {"48 }}$.

The above discussion on the formative influence of Methodism on the labour movement as well as the social role of churches and chapels in late nineteenth and early twentieth-century Britain illustrates that there exists a rich literature which deals with the influence of established religion on the re-formation of the social network on a practical level. It focuses on mechanisms and technicalities induced by or adopted from religious culture as in the case of Methodism or on the everyday grass-root relief and support provided by religious agencies on a parish level as for instance in the four districts of Lambeth. In the present thesis, I examine another aspect of how religion may have influenced the re-thinking of the social question in late-Victorian and earlyEdwardian England. In the following chapters, I focus on the ideas and values, the concepts of individual, state and social community and the assumptions on the causes and cures of poverty, which underlay the change in social organisation in the last decades of the nineteenth century. The question underlying this study is: what, if any, contribution did Anglican and Nonconformist theology make to the re-definition of the social problem between 1880 and 1914? Were there any points in social theory on which Christians generally differed from non-Christian thinkers?

Although Roman Catholics and the Jewish community added considerably to the growing network of welfare services and thereby added important aspects to the rethinking of the social question, not least the problem of immigration and cultural identity, in the following, I shall have to focus on the majority faiths of Anglicanism and Nonconformism in order to keep the present study in manageable proportions.

47 Moore, Robert Samuel, Pit-men, preachers, politics. The effects of Methodism in a Durham mining community, 1974

48 Scotland, Nigel, Methodism and the revolt of the field. A study of the methodist contribution to agricultural trade unionism in East Anglia 1872-96, 1981, p.9 


\section{The Influence of Ideas and Values in Politics and the Role of Political Thought as Potential Directive of Policy-Making}

What is the significance of ideas and values in politics and how do they impact on political discourse as well as on its practical outcome? Their influence on actual policies and on legislation is, of course, difficult to measure in its precise form and extent. But in recent years there has sprung up especially among social scientists a lively discussion on the various aspects of how and why ideas impact on decision making processes in politics ${ }^{49}$.

Scholars in the social sciences have increasingly formulated alternatives to the long-prvailing view that personal interests rather than values and ideology dominate decision taking debates in the political sphere. They have established that interests are not independent variables, but socially constructed in the sense that they are based on the decision takers' perception of a given situation and are therefore themselves highly dependent on an interpretational framework of values and beliefs. ${ }^{50}$ Politics and political debate, many academics increasingly accept, take place not only in a social and economic, but also an intellectual environment of established or contested beliefs and concepts which leave their mark on the outcome of political activity. Values and ideas, they have come to see, enter and shape political decision making processes by acting as interpretational signposts of a given situation, as determinants of conceivable solutions or as "legitimizing framework of social thought" $"$. Also, in order to be effective, political ideas and policy proposals must "deploy, re-work, or otherwise make use of the shared evaluative language of those to whom they are addressed" 52 . In their conceptualised form as political ideologies, ideas and values exercise a directive function, offering a more or less comprehensive view of what a (re-)formed society could and should look like. In democracies, they also help to generate consensus among groups of decision-takers and thus facilitate the processes of policy making ${ }^{53}$.

In his study Institutional Change and Globalisation the American social scientist John L. Campbell determined that the atmosphere for ideas, value and ideology to impact on political debate and decision-taking processes was most fertile in times of great uncertainty or crisis, a pre-condition certainly fulfilled at the time under scrutiny here as we have seen in earlier sections of this

\footnotetext{
49 see e.g. Dobbin, Frank, Forging Industrial Policy: The United States, Britin, and France in the Railway Age, 1994, esp. Chapter 1; Campbell, John L., Institutional Change and Globalisation, 2004, esp. Chapter 4

50 Hattam, Victoria, Labour Visions and State Power: The Origins of Business Unionism in the United States, 1993

51 Harris, Jose, Political Thought and the Welfare State 1870-1914: An Intellectual Framework for British Social Policy, 1999, p.44

52 Collini, Stefan, Public moralists, 1991, p.4

53 e. g. Sassoon, Anne Showstack, Gramsci and contemporary politics: beyond pessimism of the intellect, 2000; Harris, Jose, Political Thought and the Welfare State 1870-1914: An Intellectual Framework for British Social Policy, 1999; Desai, Radhika, Intellectuals and socialism: social democrats and the Labour Party, 1994
} 
introduction. ${ }^{54}$ Campbell differentiated carefully between various types of ideas and their roles in the shaping and determining of political debate and decision-taking. He distinguished between ideas which operate in the foreground of decision taking debates and those which act in the background of debates and which usually remain unarticulated and often even unacknowledged. As ideas which play overt roles in such debates Campbell defined political programmes and argumentative frames used to justify policy proposals to a wider public. In the present thesis I have set out to look at ideas of the above valence by examining the policy proposals and argumentative strategies of Christian and non-Christian social reformers and by attempting to determine whether of not Anglican and non-Conformist theology exerted a specific influence upon the debate on the social question.

But of course, the writings under scrutiny in the present study are also greatly influenced by ideas which remained unacknowledged, whose impact was subconscious or which were taken for granted and thus not explicitly spelled out in the writings examined here. Ideas which remain in the background of debates are, as explained by John Campbell, for instance societal paradigms and public sentiments which determine what is perceived as proper, fair and acceptable to those affected by particular decisions. Some of these covert influences on the debate on social reform under scrutiny in this thesis are sketched out in the following chapter.

John Campbell' argued that ideas and values which impact on debates in the background usually constrain change and limit the range of conceivable alternatives while ideas employed in the foreground of the decision taking process help along reform and modification. In the present study, we will note that these attributions are not as clear-cut as made out by Campbell - or at least, that it is sometimes very difficult in a study like the present which looks at selected writings by authors who communicated not only through their publications, but also face to face on various political platforms and social settings, to determine which of the ideas and values impacting on these authors' arguments and policy proposals really did remain covert. It is possible only to indicate which values and paradigms operating in the public realm during the period and impacting with some probability on a writer's argument in question remained unacknowledged in the writings under scrutiny here. Doing so, however, we will notice that their impact on the writers' arguments may cut both ways and that unacknowledged strands of thought and values may help along the radicalism and progressiveness of an author's arguments as much as their conservatism and diligence in another's writings. Conversely, as Campbell himself acknowledges, ideas which were initially employed to bring about change, may, once they have been institutionalised and widely accepted, hinder future reform by setting new societal paradigms and determining public sentiment.

One last factor which it may prove useful to consider at this point is that ideas do not influence

54 Campbell, John L., Institutional Change and Globalisation, 2004; see Chapter 4 The Problem of Ideas, p. 90 - 123 
debates on their own accord. In order to come into being, adapt to new circumstances and impact on the process of political decision taking, ideas, values, paradigms and programmes need to be taken up and acted upon by agents. John Campbell identified various actors who embrace, produce, modify or enforce ideas and values at various stages of the decision taking process and on various levels of the accompanying debate both in the foreground as well as in its background. He lists agents who consciously modulate and employ ideas such as the political decision takers (politicians, reformers, bureaucrats, corporate managers), theorists (academics and intellectuals) or framers (spin doctors, campaign managers, lobbyists and advertising agencies). The theories, arguments and programmes examined in the present study were all formulated by active social reformers or intellectuals of the above description. But there are also agents, often impersonal and non-human, which contribute to the distribution of the ideas, values and arguments in question and which play a decisive part in brokering their impact on debates and decision-taking processes. As brokers of ideas and values can act almost any medium or platform of communication or opinion forming, Campbell asserted, be it the media, political parties, clubs and discussion groups or trades associations to name but a few. In the following chapter we shall look at some of the agencies which acted as brokers of the ideas examined and discussed in the course of the present study.

a) A Re-Appraisal of the Classical Dichotomy between Individualism and Collectivism in lateVictorian Politics

So let us now take a closer look at some of the historiography on and at classic interpretations of the influence of ideas on social and political change during the period in question. For the period around the turn of the century, studies on the determinant ideas in secular political thought have long assumed a more or less smooth transition from the individualism of Benthamite utilitarianism to full-blown collectivism dominating the pre-war decades. The studies argue that with the public discovery of mass destitution in the last third of the nineteenth century, the focus on the happiness and well-being of the individual embodied in the doctrines of individualism and Manchester liberalism gave way to the idea that the nation constituted a community and that communal wellbeing required more than the utilitarian formula of ,the greatest happiness for the greatest number“. In consequence, they state, contemporaries abandoned the view that the individual should best be left to fight for him or herself; instead, they adopted a new view of the state as agent of the community and entrusted it with the care of the nation's communal welfare, a view often subsumed under the name of collectivism. 
The dichotomy between individualism and collectivism was famously drawn very early on in the discussion of Victorian and Edwardian political thought by Albert V. Dicey in his Lectures on the Relation Between Law and Public Opinion in England During the Nineteenth Century ${ }^{55}$. Dicey made out a gradual erosion of Benthamite utilitarianism and the time-honoured maxims of individualism (what is commonly referred to as classical „liberalism“) through Tory paternalism, franchise reform and changes in the economic and social set-up. He detected a straightforward transition in public opinion to a view of state and society which diminished the responsibilities of the individual and eroded the old virtue of self-help in favour of what Dicey described as a night watchman $\operatorname{state}^{56}$. The dichotomy between individualist and collectivist trains of thought, between attitudes inimical or favourable to state-run social programmes, has dominated much of the research on the genesis of welfare policy in Britain ${ }^{57}$. The distinction suggests itself not least because it was widely employed by contemporaries who often classified themselves, or more often still denounced their intellectual and political adversaries, as either "individualist" or "collectivist"

Especially in comparative studies of welfare states in their European or international context, the relatively clear-cut and simple criteria of individualism or hostility to state action and collectivism or favourable attitude to interventionist policies has produced some very useful and interesting results $^{59}$. In The Development of Welfare States in Europe and America, Peter Flora and Jens Alber have established a link between the kind and timing of social legislation in a given European country and the degree to which the ideas of liberalism still dominated public opinion. They argue that of the four kinds of insurance programmes usually extant in welfare states, namely insurance against accidents, sickness, old age and unemployment, workmen's compensation for accidents was most easily reconciled with traditional liberal ideas about employers' responsibilities towards his workers and thus was generally introduced first during the last decades of the nineteenth century. By contrast, state-run insurance schemes against unemployment jarred most with Liberal values such as self-help and laissez-faire and thus took longest to be introduced, in one case as late as $1934^{60}$.

In a study on the ideas behind the genesis of the British welfare state in the twentieth century, the historian John Offer chose to view the development from the opposite angle, but employing the

\footnotetext{
55 Dicey, Albert Venn and Emlyn Capel Stewart Wade, Lectures on the relation between law and public opinion in England during the nineteenth century, 1962

56 Dicey, Albert Venn and Emlyn Capel Stewart Wade, Lectures on the relation between law und public opinion in England during the nineteenth century, 1962, Lecture VII

57 See e. g. Barker, Rodney, Politics, peoples and government, 1994

58 Meadowcroft, James, Conceptualizing the state, 1995, p.230ff

59 Esping-Andersen, Gosta, The three worlds of welfare capitalism, 1990

60 Flora, Peter and Jens Alber, Modernization, Democratization and the Development of Welfare States in Western Europe, 1981, p.48ff
} 
same model. He argued that the predominance of idealism in Britain, which contributed to the rediscovery of the idea of a common good and of the positive moral functions of the state, helped to give preference to state aid schemes over informal care options in the construction of the British welfare system well into the $1970 \mathrm{~s}^{61}$. The sociologist Gosta Esping-Andersen argued that the Scandinavian model of welfare economy developed thanks to the prevalent tradition of collectivism and solidarity in Sweden ${ }^{62}$.

But the dichotomy between an emphasis on the responsibility of the individual for his or her own well-being and state liability for communal welfare was not as clear-cut as these studies make out. There existed considerable overlap between the two views at any time during the period under scrutiny and beyond. The focus on a bisection between individualism and collectivism as determinants of welfare policies has often led historians and students of social policy to focus on the state as prime agent and supporting pillar of welfare systems and to ignore the contributions of voluntarism. Recent discussion has re-discovered informal care, voluntary support, self-help and private philanthropy as integral elements of modern welfare systems ${ }^{63}$. The new point of view has cast doubt on a clear-cut transition from individualism to collectivism and from emphasis on individual responsibility to comprehensive state-run support schemes. As early as 1977, Harold Perkin has negated the alleged dichotomy by defining seven different kinds, or stages, of what Victorians and Edwardians understood by "collectivism". His spectrum ranged from selective state intervention to prevent obvious moral nuisances or physical dangers such as represented by the earliest Factory Acts to the nationalisation of certain (or all) means of production, distribution and exchange which underlay, for instance, the running of the Post Office ${ }^{64}$.

Studies of the Poor Law Reports by Alan McBriar and Andrew Vincent, often portrayed as the classic clash of rival social ideologies as expounded, for instance, by the Charity Organisation Society and the Fabians, have shown a surprisingly large overlap in ideas and underlying values in the supposedly individualist Majority Report and the collectivist, as it was presented, Minority Report $^{65}$. Research on the philosophical current of idealism, a prime mover in the re-appraisal and re-definition of social questions in the nineteenth century, has drawn a colourful and many-faceted picture of the philosophy, demonstrating how its core ideas on the value of community, the worth of the individual and the moral function of the state could inspire pro-statist political factions as much

\footnotetext{
Offer, John, An intellectual history of British social policy, 2006

Esping-Andersen, Gosta, The three worlds of welfare capitalism, 1990, p.223

63 See e. g. Lewis, Jane, The Voluntary Sector in the Mixed Economy of Welfare, 1999; Green, David G., The Friendly Societies and Adam Smith Liberalism, 1999

64 Perkin, Harold, Individualism versus Collectivism in Nineteenth-Century Britain: A False Antithesis, 1977

65 McBriar, Alan M., An Edwardian mixed doubles, 1987; Vincent, Andrew W., The Poor Law Reports of 1909 and the Social Theory of the Charity Organisation Society, 1999
} 
as supporters of traditional liberal values ${ }^{66}$. The new research has enabled historians of social support systems as much as students of the political thought behind them to paint a varied and rich picture of how the British welfare state evolved and why it developed the way it did, taking into account all three main pillars of the system, namely private philanthropy, self-help and state provisions.

b) The Influence of Theology and Religious Belief on Political Thought

Religious belief and theology have for centuries been among the defining influences on the values, concepts and ideas of right and wrong of a given age, and religious phraseology and rhetoric have long served as vehicles to communicate and justify those notions to the public at large. Today, modern secularised society tends to marginalise the importance of Christianity for the lives of contemporary men and women. But as we have seen above, despite their losses in the number of regular worshippers, around the turn of the century the churches held considerable influence over British society as providers of material and spiritual support, educators, caretakers and guardians of an ethical frame of reference.

In a wide-ranging study of the relations between governmental organisation and prevalent religious beliefs in European countries over the course of a century, the historian David Nicholls has argued that political and theological discourse were interdependent and reacted to each other in a two-way process $^{67}$. Nicholls pointed out that images of deity and secular power often overlapped. Concepts of God, he explained, were commonly borrowed from political discourse and carried with them political connotations as references to the divine as king, lord, judge or ruler and attributes like might, sovereignty, majesty or omnipotence illustrate. But having come into being, Nicholls argued, such concepts took on a life of their own and tended to affect the way later generations thought not only about God, but also about their social and civic life. "Theological rhetoric, child of political experience, may also be mother of political change" ${ }^{\prime 6}$, he concluded.

Recent literature in the social sciences has rediscovered religion as a formative influence on the various shapes and models of welfare systems in European countries. Philip Manow and Kees von Kersbergen argued in their publication Religion, Class Coalition and Welfare States ${ }^{69}$ that the timing of welfare reform and its scope and direction were influenced not only by the onset of class

\footnotetext{
66 Vincent, Andrew W., The Poor Law Reports of 1909 and the Social Theory of the Charity Organisation Society, 1999; Den Otter, Sandra M., British Idealism and social explanation: a study in late Victorian thought, 1996

67 Nicholls, David, Deity and domination, 1989

68 Nicholls, David, Deity and domination, 1989, p.14

69 Manow, Philip and Kees van Kersbergen, Religion, Class Coalitions and Welfare States, 2009
} 
antagonism brought about by the industrial revolution during the second half of the nineteenth century, but also by whether or not a particular country experienced religious cleavages, whether in the form of anti-clericalism or inter-confessional strive. In countries shaken by religious disunity and conflict, they explained, there tended to form parties of religious or confessional defence which gained influence, for instance, as coalition partners and carried their interests and doctrines into the political debate and policy making processes during the formative years of early welfare legislation. In countries of relative religious homogeneity, on the other hand, no such parties of religious defence emerged and religion tended not to become politicised.

Taking up the idea of religious cleavages and their influence via a country's party system and using the example of work-family policies in Western Europe, Kimberley Morgan ${ }^{70}$ argued that in the Nordic countries with their relative religious homogeneity, their fusion of church and state and their consequent lack of parties of religious defence, the state as legislative organ tended to distance itself from patriarchalism in the formulation of early family-related legislation and viewed women as citizens with rights independent of their roles as mothers. The result, as can be seen for instance in Sweden, Denmark or Norway, were extensive public provisions for child care thereby enabling women to enter employment and helping to eventually challenge and abolish the male-breadwinner model. In countries with a stronger influence of Catholicism, by contrast, Morgan argued, familialism and the patriarchal male-breadwinner-model retained a dominant influence on familyrelated welfare legislation via the parties of Christian democracy. Therefore, in Italy and Belgium, for instance, child care remained family responsibility and in line with the Catholic principle of subsidiarity, only very few public provisions for the care of children under the age of three were introduced. The exception to this, Morgan pointed out, was France where anti-clericalism was strong and no party of religious defence could gain ground until after the second World War. Thus, in France the state managed to enlarge its powers in social legislation against the influence of religious associations and institute extensive provisions for child care against the familial principle. In countries such as Germany, Austria and the Netherlands where religious conflict was primarily inter-confessional, Morgan detected an accommodationist model of family-related welfare policies. In such countries, the state tended to assume responsibility, but in the administration of welfare provisions worked together closely with the churches and voluntary associations.

Sigrun Kahl offered an alternative causal pathway to the tenet of religious cleavages in order to trace the influence of religion on social policy ${ }^{71}$. Choosing the example of poor relief, she focused on the ideas and doctrines of various denominations which left their marks on early welfare 
legislation in European states and detected marked differences between the systems of poor relief of Catholic, Calvinist and Lutheran welfare states. Kahl argued that systems of poor relief were in place long before European states began to regard welfare as part of their jurisdiction. Those systems were usually run by churches and religious institutions which fashioned them according to their values and beliefs. When states began to take upon themselves the responsibility for the wellbeing of their citizens they usually capitalised on the mechanisms already in existence and thereby took over also many of the principles and doctrines underlying their design.

The Catholic tradition which influenced for instance legislation in Italy and Spain, Kahl maintained, held fast to its traditional belief in the value of charity and thus embodied the principle of Christian benevolence where poor relief remained the prerogative of private, voluntary or religious organisations according to the principle of subsidiarity and the state stepped in only as a last resort. In Kahl's understanding, Calvinist states embraced the converse principle holding that whoever did not work, neither should he eat. Kahl held that countries steeped in Calvinism with its emphasis on the redeeming powers of labour such as the Netherlands or Great Britain institutionalised responsibility not "for but of the poor, enforcing work discipline and providing only meagre relief" ${ }^{\prime 72}$. The shibboleth of Calvinist poor relief systems for Kahl are work houses so typically found in England, the Netherlands and the United States. Lutheran states according to Kahl let themselves be guided by the double principle of "all should eat, all should work" "73. Such states - a good example is Sweden - asserted the able-bodied individual's duty to contribute to the common good through their labour. At the same time, however, they rejected both the Calvinist belief that every man forged his own fortune (within the framework of the doctrine of predestination) as well as the Catholic practice of charity as a means to buy one's way into heaven. Lutheran states, Kahl showed, classified care for the poor as a communal responsibility to be executed by a central authority - the municipality or state. They were among the earliest to institute the common chest or poor tax, secular regulation and localised administration of poor relief. Nonetheless, despite the secularised and laicized character of Lutheran poor relief systems, the local parish as the smallest administrative units of such states often remained the distributor of relief and thus ensured the influence of the churches in the system of welfare.

In his book The Age of Atonement. The Influence of Evangelicalism on Social and Economic Thought 1785-1865, ${ }^{74}$ the historian Boyd Hilton has illustrated Kahl's theory on Calvinist poor relief systems for Britain in the first half of the nineteenth century. He, too, detected a mutual

Kahl, Sigrun, Religious Doctrines and Poor Relief: A Different Causal Pathway, 2009, p. 289

73 Kahl, Sigrun, Religious Doctrines and Poor Relief: A Different Causal Pathway, 2009, p.271

74 Hilton, Boyd, The Age of Atonement. The Influence of Evangelicalism on Social and Economic Thought 1785-1865, 1988 
impregnation of religious and secular value systems and world views. Hilton stressed the coincidence as dominant modes of thought in the first decades of Victoria's reign between a stark, individualistic and sin-oriented Evangelical religion and the Smith-Ricardian school of political economy with its equally individualistic and unforgiving doctrines of laissez-faire and personal responsibility. By 1870, however, the period dealt with in the present thesis, Hilton argued that legislative measures like limited liability had rang in a softening of the austere political economy of Manchester liberalism, a development mirrored, heralded and, he implies, even partly initiated by an equal softening in the image of the divine, from a wrathful retributive and unforgiving God to a humanised, loving and caring Father.

David Nicholls detected a similar development between the image of a benevolent and loving God and the notion of a paternalist welfare state in Britain during the last third of the nineteenth century. He reported how the newly emerging currents of liberal theology and Anglo-Catholicism rediscovered a concept of God as father or friend; the two religious movements shall be examined at greater length in the following sections. Nicholls argued that this idea of a loving God was complemented in the secular sphere by an idea of the state, as one writer put it, as a wise and caring grandmother ${ }^{75}$ : both sovereigns, divine as well as worldly, possessed absolute power, but used it to effect the well-being and happiness of their charges. Nicholls conjectured that the ideas reflected in liberal theology on benign sovereignty influenced the social policies of New Liberalism through men like William Beveridge and Herbert Asquith $^{76}$.

But one must be careful not to fall into the trap of making out too smooth a passage from austere evangelicalism and Manchester liberalism with their joint emphasis on individual self-reliance at the beginning of the nineteenth century to the idea of a caring, benevolent God and welfare politics at the end. Boyd Hilton and David Nicholls both arguably overstressed the evenness of the transition in the notions of divine and worldly authority. Like the study of secular political thought, the interpretation of theology and religious thought and its impact on the values and ideas of their times, too, require a diversification of views. In religion, as in economics and political thought, historical research has pointed out a myriad of counter-movements and strands of thought which transcended the periodisation into evangelical and liberal Christianity, and individualist versus collectivist political theory.

Romantics like Carlyle and Samuel Taylor Coleridge ${ }^{77}$, for instance, employed an image of God and creation which stressed the value of beauty and sensuality in the face of Puritan austerity at the

75 Henry Scott Holland as quoted in Nicholls, David, Deity and domination, 1989, p.59

76 Nicholls, David, Deity and domination, 1989, p.64ff

77 Thomas Carlyle (1795 - 1881) was a Scottish writer and historian; Samuel Taylor Coleridge (1772 - 1834), poet, literary critic and philosopher, was one of the founders of the English Romantic movement as well as one of the Lake Poets. 
beginning of the century. The Chartist Movement of the 1840 s combined a radical political programme with a strong religious element, claiming Jesus as the first social rights activist as one among their numbers and opposing the class-ridden institutions of the established churches. ${ }^{78}$ The religious movement of Noetics as pioneered at Oriel College, Oxford, influenced early Tory paternalist factory legislation through men like Richard Whateley, William Sturges Bourne and Nassau Senior ${ }^{79}$. At the same time, austere evangelicalism remained a strong force alongside a more lenient liberal this-worldly religion well into the twentieth century as, for example, the continuing strength of sabbatarianism illustrate ${ }^{80}$. When reading the study at hand one should therefore bear in mind that the thinkers examined in detail in the following chapters represent only certain facets of the spectrum of political opinion and religious doctrine.

\section{The Rise of Social Theology in Victorian Britain}

a) The Oxford Movement, Anglo-Catholicism and Slum Ritualism

As Hilton and Nicholls among others suggested, there are currents in Anglican and Nonconformist theology which (re-)introduced an image of a benevolent and loving God into contemporary belief and which seem to have been particularly popular with Christian social reformers. Such a current, peculiar to Anglicanism, was the ecclesiastical reform course instigated by the Oxford Movement. The Oxford Movement started as a protest against the strong influence of the secular authorities over the church. In a series of tracts entitled Tracts for the Times, published between 1833 and 1841, a group of clerics around the Oxford dons John Keble, Edward Bouverie Pusey and John Henry Newman ${ }^{81}$ turned away from the Erastian model of church government and campaigned for the church's independence from secular authorities. The Tractarians, as they came to be known, emphasised that the Anglican Church was, together with Eastern Orthodoxy and Roman Catholicism, a branch of the One Holy Apostolic Catholic Church. The movement culminated in Newman's famous Tract 90 in which he argued that the doctrines of the Roman Catholic Church as laid down by the Council of Trent were compatible with the Thirty-Nine Articles of the Church of

\footnotetext{
8 Norman, Edward, The Victorian Christian socialists, 1987, p.10

79 Offer, John, An intellectual history of British social policy, 2006, p.13f.

80 See e. g. McLeod, Hugh, Religion and irreligion in Victorian England, 1993

81 John Keble (1792 - 1866); Edward Bouverie Pusey (1800 - 1882); John Henry Newman (1801 - 1890). Newman converted to Roman Catholicism in 1845.
} 
England. Few of the movement's sympathisers followed Newman's lead in converting to Roman Catholicism, but the Oxford movement opened up the way for a strengthening of a more sensual and ritualist approach to religion within the Church of England which became known as AngloCatholicism ${ }^{82}$.

Anglo-Catholics claimed a valid apostolic succession for the Church of England and thus held a "high" view of the episcopate. In opposition to Evangelicalism, Anglo-Catholics placed great emphasis on the sacraments. Some Anglo-Catholic clerics celebrated in their parishes the sacrament of holy confession and anointed the sick and the dying. All stressed the tantamount importance of the Eucharist, underlining its sacrificial character and claiming the real presence of Christ in bread and wine at the Mass. To underscore the beauty and holiness of the sacraments, Anglo-Catholics reintroduced ritual such as Eucharistic vestments and the use of incense and candles into their services. This ritualism caused offence among sections of Victorian society. Strict Evangelicals objected to what they saw as Romish tendencies as much as to the this-worldly aspect brought into the church through "smells and bells". Several priests were prosecuted and imprisoned for their ritualist leanings under the Public Worship Act of $1874^{83}$.

Curiously, ritualism as a movement appears to have been particularly successful in working class areas. Some of the hotspots of ritualist Anglo-Catholicism lay in the worst neighbourhoods of English industrial towns, such as St. Saviour's, Leeds, St. Alban's, Holborn, St. John the Divine, Kennington, or St. Peter's, London Docks. The 1882 religious census showed attendance at some of the poorest ritualist churches in London to have been well above the average for Anglican institutions ${ }^{84}$, possibly also because the graphic nature and sensual approach of these services may have attracted communicants from neighbouring parishes ${ }^{85}$.

Whoever the regular parishioners of these establishments may have been, it remains true that some of the most noticeable and outspoken social workers within the Church of England in the lateVictorian period were ritualist slum priests. Men like Robert Dolling, Daniel Elsdale or Father Stanton acquired fame as some kind of working class heroes. The emphasis on good works entailed by their faith, their insistence that the Church of England must no longer be content to serve as a prop to the establishment - to be the proverbial "Tory party at prayer" -, their personal dedication as well as their acceptance as part of God's creation of all things worldly and material may have predisposed them to meet the needs of their parishioners particularly aptly. Ritualist social work took place both on the local level as well as on a national level in the form of, for instance, the

\footnotetext{
82 Yates, Nigel, The Oxford Movement and Anglican ritualism, 1984

83 Best known are probably the cases of Arthur Tooth of St. James, Hatcham, and James Bell Cox of St. Margaret's, Liverpool; for details see Yates, Nigel, Anglican ritualism in Victorian Britain, 1830-1910, 1999

84 Pickering, William Stuart Frederick, Anglo-Catholicism: a study in religious ambiguity, 1991

85 Reed, John Shelton, Glorious battle, 1996, p.152-155
} 
Anglo-Catholic Church of England Working Men's Association ${ }^{86}$. The Anglican sisterhoods which acquired such an important place in the history of social work, too, have their origins in the Oxford Movement and most adopted Anglo-Catholic ritual as their mode of liturgical practice ${ }^{87}$.

\section{b) Frederick Denison Maurice}

Parallel to the ecclesiastical renewal brought about by the Oxford Movement within the Church of England began a softening of theology through the writings and thought of Frederick Denison Maurice $^{88}$. Born in 1805 as the son of a Unitarian minister, Maurice converted to Anglicanism as an adult and took holy orders. He worked first as chaplain of Guy's Hospital, London, before being appointed professor for English literature, and later theology, at King's College in 1840. In 1838, Maurice published the book in which he laid down the foundations of his theology, The Kingdom of Christ $^{89}$. The book is laid out as a series of conversations about theological questions between two men, one Church of England, the other Unitarian. The Anglican aims at explaining and justifying the metaphysical, other-worldly aspects of his creed to the staunchly this-worldly, rational Unitarian. The lay-out of the book suggests that, in it, Maurice recorded some of his own spiritual troubles in the wake of his conversion and his personal solutions to religious questions.

In The Kingdom of Christ, Maurice fought against the fire and brimstone teachings of Evangelicalism. He rejected the doctrine of everlasting torment and challenged the idea of a division of mankind into saved and damned. In the book, he began to replace the stern and irascible God of the Puritans by an image of God as father which he deduced from the doctrine of the Incarnation. If Jesus had become man and as such was the son of God, Maurice reasoned, then all men were God's children. From the Fatherhood of God Maurice inferred a universal brotherhood of men. Maurice offended contemporaries by insisting that Christianity had a social application, that politics and religion were inseparable and that the Church should play an active role in the political and economic life of modern society. For him, the Kingdom of Christ was not a place in the clouds, but a reality which men ought to strive to establish in this world.

Maurician theology proved highly liberating to many young students and exercised great influence

86 See eg. Reed, John Shelton, Glorious battle, 1996; Yates, Nigel, The Oxford Movement and Anglican ritualism, 1984; Yates, Nigel, Anglican ritualism in Victorian Britain, 1830-1910, 1999

87 Reed, John Shelton, Glorious battle, 1996

88 Jones, Peter d'Alroy, The Christian socialist revival 1877 - 1914. Religion, class, and social conscience in lateVictorian England, 1968, p.9-14; Phillips, Paul T., A kingdom on earth, 1996, p.1-6; Norman, Edward, The Victorian Christian socialists, 1987, p.14-34; Hilton, Boyd, The age of atonement, 1988, p.270-5

89 Maurice, Frederick Denison, The kingdom of Christ, or hints to a Quaker, respecting the principles, constitution, and ordnances of the catholic church, 1838 
over later generations of Anglican clerics. But Maurice also provided a path-breaking practical example of how to apply this new interpretation of Scripture to social and political questions of contemporary society. He was co-founder of the first Christian Socialist group in England in 1848 and has been credited with inventing the term Christian Socialism. The group will be described in some more detail in connection with the Christian Socialist revival in the last quarter of the nineteenth century in section 5 of the present chapter.

c) Liberal Theology

Besides the ecclesiastical currents of Anglo-Catholicism and ritualism which stemmed from the Oxford Movement as well as the new theological conjectures of F. D. Maurice, a third influence which led to the re-thinking of established dogma within the Church of England was the rise of liberal theology. New research in the natural sciences and the new practice of historical criticism carried over to British universities from the continent had cast doubt on a literal interpretation of Scripture. In 1860, a year after Darwin's Origin of Species, appeared Essays and Reviews ${ }^{90}$, a collection of contributions to modern theological problems from seven clerics Among the writers were such influential thinkers as Benjamin Jowett, Master of Balliol College, Oxford, and Frederick Temple, the future Archbishop of Canterbury ${ }^{91}$. The book comprised controversial arguments such as Baden Powell's statement that belief in miracles was heretical as miracles contradicted the Godgiven laws of nature.

Essays and Reviews together with Maurician theology and Anglo-Catholicism formed an important influence on a later generation of Anglican priests, educated at Oxford. In 1889, a group around the Balliol graduates Charles Gore ${ }^{92}$ and Henry Scott Holland ${ }^{93}$ published Lux Mundi. A series of studies in the religion of the Incarnation ${ }^{94}$ in which, in the tradition of the theological currents identified above, they aimed to reconcile theological doctrine not only with new discoveries in the

$90 \quad$ Temple, Frederick, Essays and Reviews, 1860

91 Benjamin Jowett (1817 - 1893), Master of Balliol College from 1870; Frederick Temple (1821 - 1902), Archbishop of Canterbury from 1896 until his death. He was the father of William Temple $(1881-1944)$, Christian social activist and Archbishop of Canterbury (1942 - 1944).

92 Charles Gore (1853 - 1932), Anglican divine and bishop. He was educated at Balliol College, Oxford, where he came under the influence of the Idealist philosopher T. H. Green. In 1884, he became first head of Pusey House, Oxford, but resigned his principalship to become successively canon of Westminster Cathedral (1894), Bishop of Worcester (1902), Bishop of Birmingham (1905) and Bishop of Oxford (1911). In 1889, he co-founded the Christian Social Union in conjunction with Henry Scott Holland.

93 Henry Scott Holland (1847 - 1918). Educated at Balliol College, Oxford, he studied under T. H. Green. He was fiercely interested in social issues from an early age, founding the discussion group PESEK (Politics, Economics, Socialism, Ethics and Christianity) during his student days at Oxford. Holland was canon of St. Paul's Cathedral from 1884. He returned to Oxford in 1910 as Regius Professor of Divinity.

94 Gore, Charles, Lux Mundi: a series of studies in the religion of the incarnation, 1890 
sciences, but also with the problems posed by modern industrialised society. Concerned about what they perceived as the waning importance of the Church in contemporary society, they aimed at modernising Anglican theology in order to give it new relevance in industrialised Britain. As Scott Holland put it in view of the declining church attendance among the working classes, in modern life, Christianity was to be experienced, not contemplated. The Mundites followed Maurice in placing great emphasis on the idea of the Incarnation. They argued that Christ, when coming into the world, had shed all divine attributes and become wholly man. Like Maurice, they turned from the otherworldliness of evangelicalism to a this-worldly creed which believed that Christ in the Incarnation had sanctified all things human and all aspects of human nature. From the idea of the Fatherhood of God and the corresponding brotherhood of men they developed a communal religion, arguing that Christianity was best realised not in private prayer and solitary contemplation, but in a living community and through an active life in the service of others.

c) Nonconformity

Anglicanism pioneered the way towards a social theology, but Nonconformity followed suit. John Clifford has been credited with opening up the traditionally conservative denomination of Baptism to secular issues ${ }^{95}$. His Praed Street Baptist Church became a centre of social agitation and Clifford served as an ardent supporter of, among other things, franchise extension and the trade union movement. He contributed two influential Fabian Tracts on Socialism and the Teachings of Christ and on Socialism and the Churches ${ }^{96}$. In Methodism, the Forward Movement of the 1880s and 90s around Hugh Price Hughes bore witness to a tendency towards modernisation and politicization ${ }^{97}$. Hughes introduced the question of social salvation into a denomination which had hitherto focused primarily on personal salvation. He believed in Jesus Christ as a social reformer and preached that Scripture held a social directive in addition to its spiritual message. The task of the churches in social reform as Hughes saw it was to play the role of the nation's conscience: they were to act as motivating powers in the process of generating a political will to end the misery of the masses. With his zeal to introduce morality into the political sphere, Hughes was a prime exponent of the

95 John Clifford (1836 - 1923), son of a Chartist lace-maker, was from 1858 minister at Praed Street Baptist Church in London Paddington. He served as president of the London Baptist Association in 1879, and of the Baptist Union in 1888 and 1899. Clifford was a supporter of the London match girls (1888) and the London dockers (1889) in their strikes for better wages and working conditions. He is known as a pacifist and fierce critic of the Boer War and World War One.

96 Clifford, John, Socialism and the teaching of Christ, 1906; see also Clifford, John, Socialism and the churches, 1908

97 Hugh Price Hughes (1847 - 1902) was the founder of the Methodist Times (1885) and founding Superintendent of the West London Methodist Mission (from 1887). 
mentality which came to be known as the "Nonconformist conscience"

The most broadly influential Nonconformist attempt at a social theology at the time, although very late in the period under scrutiny, was undoubtedly Reginald John Campbell's New Theology Movement $^{99}$. The Congregationalist Campbell ${ }^{100}$ stressed the idea of divine immanence, an idea which had in recent decades already influenced men like John Clifford. He rejected the dualism which differentiated between God and his external creation and argued that God remained present in every aspect of the world. In the figure of Jesus Christ, God had confirmed his special relationship with man, sanctifying all things human. In his two books Christianity and the Social Order, published in 1907, and The New Theology and the Socialist Movement which followed in 1908, Campbell acknowledged the essentially social message of the New Testament. In Campbell's eyes, Christ had sought to bring paradise onto the earth. With its emphasis on social justice and communal welfare, socialism constituted for him but the latest in a series of practical expressions of Christian ethics and the gospel of Christ, the most recent expression of an age-old spiritual movement within the world.

\section{Christian Socialism: A phenomenon of many shapes and variances}

This spate of integrating social elements into certain strands of Anglican and Nonconformist theology, coupled with frequent use of the term among contemporaries, has prompted historians to speak of a Christian Socialist revival movement for the period between 1880 and $1914^{101}$. The idea of such a movement in a coherent uniform shape is, however, highly problematic. There appears to be little commonality between those who typically fall under the title Christian Socialist apart from their realisation that the social question demanded action urgently. On inspection, the term Christian Socialism as employed by contemporaries as well as by some historians is diffuse and cloudy, the ideas associated with it diverse and sometimes even conflicting. Neither the theology nor the

\footnotetext{
98 Oldstone-Moore, Christopher, Hugh Price Hughes: founder of a new Methodism, conscience of a new Nonconformity, 1999; see also Norman, Edward, The Victorian Christian socialists, 1987, p.144-161

99 Jones, Peter d'Alroy, The Christian socialist revival 1877 - 1914. Religion, class, and social conscience in lateVictorian England, 1968, p.423

100 Reginald John Campbell (1867 - 1956). After graduating from Oxford in 1895, he accepted a position at the Congregational Union Street Church, Brighton. In 1903, he moved to the City Temple, London, where he remained for the rest of his life.

101 Jones, Peter d'Alroy, The Christian socialist revival 1877 - 1914. Religion, class, and social conscience in lateVictorian England, 1968
} 
political programme propagated by the people associated with Christian Socialist organisations can be reduced to a common denominator; nor did they agree on a clear and joint definition of the term socialism.

The term Christian Socialism was borrowed by contemporaries from an earlier group of socially minded Christians who in 1848 gathered around the triumvirate of Frederick Denison Maurice, John Malcolm Ludlow ${ }^{102}$ and Charles Kingsley ${ }^{103}$. This earlier group pursued a dual aim, wanting to tame and tamper the secular socialist movement, represented at the time by Chartists and O'Brienites, whom they perceived as destructive and potentially dangerous in their class-bias and revolutionary zeal. On the other hand, however, they also meant to shake up their fellow Christians and to force them to consider the social and political implications of their faith. In Maurice's words, they tried to deliberately shock into action both the "unsocial Christians and the unChristian Socialists"104

We have already encountered some tenets of Maurician theology and seen how they opened up new avenues of belief for liberally-minded Christians. Politically, Maurice remained a conservative, suspicious of democracy, and aiming at a "brotherhood of men" which unfolded in a harmonious and unified, but hierarchical, class-based society. John Ludlow, whom historians of the movement judge to be the true instigator of the group, believed in franchise extension and equality, but his economic ideas did not go much beyond the French co-operative ideal of economists such as Buchez, Lamennais and Blanc ${ }^{105}$. In their practical work, the early Christian Socialists thus focused on producer co-operatives and, after the failure of their pioneering groups, settled on adult education with the Working Men's College in London. The group dissolved in 1854.

The name Christian Socialist re-appeared during the 1880 s as a convenient programmatic tag for a myriad of Christian social reformist organisations of all denominations, from the Church of England, to Roman Catholicism to such marginal denominations as the Swedenborgians. The first Christian Socialist group to form in the later period, and the one to revive the name and association with Maurice, was Stewart Headlam's Anglican Guild of St. Matthew (GSM). Headlam had studied under Maurice as an undergraduate at Cambridge and with the foundation of his group acknowledged his intellectual debt to his teacher ${ }^{106}$. Within the Church of England, the Guild was followed in 1889 by the Christian Social Union under the leadership of Charles Gore and Henry Scott Holland, co-authors of Lux Mundi. In 1906, Anglican Christian Socialism saw the formation

\footnotetext{
102 John Malcolm Forbes Ludlow (1821 - 1911), lawyer and social activist, was a prominent supporter of the cooperative movement.

103 Charles Kingsley $(1819$ - 1875), was a novelist and social activist.

104 Norman, Edward, The Victorian Christian socialists, 1987, p.8

105 Jones, Peter d'Alroy, The Christian socialist revival 1877 - 1914. Religion, class, and social conscience in lateVictorian England, 1968p.14-22

106 Leech, Kenneth, Stewart Headlam 1847-1924 and the Guild of St. Matthew, 1968, p.61
} 
of the Church Socialist League in the wake of the Labour Party formation.

Other denominations followed suit in founding their own Christian Socialist organisations. The Socialist Quaker Society, for instance, operated from 1898 to 1924. The Swedenborgian New Church Socialist Society was founded in 1895 and seems to have ceased around 1901. The historian Peter d'Alroy Jones believes that by the turn of the century there was no denomination which did not sport some kind of Christian Socialist organisation or institution ${ }^{107}$. There were some attempts to overcome sectarian division and to unite Christian Socialists of all faiths under a common banner. In 1886, Charles Marson, a prominent member of Headlam's GSM, W. Howard Paul Campbell, a member of the Marxist SDF and Alfred Howard, a member of the Fabian Society, founded the Christian Socialist Society, but the group failed for want of a clear profile after a couple of years. A myriad of non-sectarian follow-up organisations such as John Clifford's Christian Socialist League (1894-1998), the Christian Social Brotherhood (1898-1903) and the Free Church League (founded 1909) were similarly short-lived.

The difficulty in defining Christian Socialism as a concerted movement between 1880 and the First World War which I have spoken off in the introductory paragraph of this section, is primarily one of missing political congruence. In their secular, social and economic policy proposals, the above societies varied widely. The historian Edward Norman has tried to draw out a certain co-incidence of political values and economic aims between individual leaders of Christian Socialist groups, but found little concurrence beyond a rejection of the principle of unlimited competition as endorsed by classical political economy ${ }^{108}$. Peter d'Alroy Jones calls Christian Socialism an enigma. He conjectures that if Christian Socialism had any distinctive meaning at all in the history of modern socialist thought, it was "personalist rather than individualist, voluntarist rather than statist, and associationist rather than collectivist" ${ }^{\prime 109}$.

Jones' conjecture is, however, by necessity a generalisation as the economic programmes of the Christian Socialist groups of the period under scrutiny oscillated between full-scale nationalisation and mild welfare measures coupled with voluntary action. ${ }^{110}$ Campaigns for extensive land reform on a Georgeist model occupied, for instance, the Anglican Guild of St. Matthew and the interdenominational Free Church Socialist League. John Clifford's Christian Socialist League supported the collective ownership of all material means of production, as did the Anglican Church

\footnotetext{
107 Jones, Peter d'Alroy, The Christian socialist revival 1877 - 1914. Religion, class, and social conscience in lateVictorian England, 1968, p.5

108 Norman, Edward, The Victorian Christian socialists, 1987, p.2

109 Jones, Peter d'Alroy, The Christian socialist revival 1877 - 1914. Religion, class, and social conscience in lateVictorian England, 1968, p.6

${ }^{110}$ For details on the following, see Jones, Peter d'Alroy, The Christian socialist revival 1877 - 1914. Religion, class, and social conscience in late-Victorian England, 1968, p.431ff.
} 
Socialist League although later, under the influence of J. N. Figgis, this latter group drifted into Guild Socialism ${ }^{111}$. Other organisations favoured less radical measures. The Christian Social Union supported state-run welfare systems such as compulsory elementary and secondary education, school meals, unemployment benefits and labour exchanges, but shied away from full-scale nationalisation of either land or capital. They urged voluntary measures such as consumers' cooperatives and called for boycotts of sweated products or articles produced under dangerous conditions. The Socialist Quaker Society took a strong stand on all issues involving personal freedom, investing much energy in the causes of anti-imperialism, pacifism and women's rights. Their socialism aimed at municipal control of certain trades such as gas, water, electricity and the milk trade, and a national health service. In terms of their political demand, Christian Socialists proved equally divergent, ranging from calls for full enfranchisement and total equality to a mellowed form of a benevolent paternalism.

The confusion over the precise meaning of the term "socialism" was, of course, aggravated by a similar lack of clarity in the secular socialist movement at large. The phrase was used to denote a very wide variety of broadly defined progressive modes of thought aiming at greater co-operation and assuming the existence of a common good. The three major secular socialist organisations of the period, the Social Democratic Federation (SDF), the Fabian Society and the Independent Labour Party (ILP), all treated Socialism as a political ideology aiming at a strong state and enhanced governmental responsibilities ${ }^{112}$. They differed, however, in the particulars of their respective interpretations of what Socialism entailed. While the SDF was Marxist in outlook, emphasising class antagonism and the need for a revolution, the Fabians and the ILP favoured gradual reforms through existing political institutions. The Marxist SDF, dominated by Henry Mayers Hyndman, called for a full-scale nationalisation of all means of production. Fabian thought, much more a compound of the ideas of many individual thinkers than Hyndman's group, favoured a collectivist approach, proposing the state or municipal ownership of key resources such as the land and the provision of certain services and welfare measures ${ }^{113}$. The ILP stood in the tradition of Liberal Radicalism $^{114}$, as Eugenio Biagini and Alistair Reid have argued, calling for economic equality to follow social and political equality. Besides a commitment to an eight hours day, tax reform and free education, it did, however, also include the collective ownership of the means of production among its objectives ${ }^{115}$.

\footnotetext{
111 For Figgis and pluralism/guild socialism, see Nicholls, David, The pluralist state, 1994

112 Laybourn, Keith, The rise of socialism in Britain, 1997

113 Hill, Clive E., Understanding the Fabian essays in socialism (1889), 1996

114 Biagini, Eugenio F. and Alastair J. Reid, Currents of radicalism: popular radicalism, organised labour and party politics in Britain, 1850-1914, 1991, p.18f

115 Laybourn, Keith, The rise of socialism in Britain, 1997, p.26-38
} 
Next to the three groups who interpreted socialism as a theory of state and government there existed a myriad of other strands of thought which considered socialism a creed or way of life rather than an ideology of political reform. The biologist Alfred Wallace represents a school of thought which regarded socialism not so much as a political programme than as the necessary, ultimate state in human evolution, the outcome of man's moral sentiment and intelligence ${ }^{116}$. John Ruskin stands for an aesthetic school of socialism. Exponents of ethical socialism such as William Morris' Socialist League laid their greatest emphasis on the vision of a better society based on the principles of justice, equality and brotherhood. The activities organised by the ethically-minded Clarion group ${ }^{117}$ or the Labour Church Movement ${ }^{118}$, for instance the cycling clubs, choirs, and potato-pie dinners, aimed at offering a glimpse of how the new society could work on an everyday basis without placing undue stress on the politics or economics of it.

Ethical socialism underlined the necessity of individual commitment and personal moral reform in the socialist re-organisation of society ${ }^{119}$. Although it drew groups of adherents in its own right, the ethical principle also permeated all forms of economic and political socialist opinion. Sidney Ball and David Ritchie from the Fabian Society for example both spoke of the moral aspects of socialism. The difficulty of pinning down the exact meaning and content of socialism was reflected for instance by the Rainbow Circle, a progressive discussion group comprising men of all shades of progressive opinion, who could agree only on a very broad definition of socialism as "every tendency having for its object real equality among men" and aiming at the common good of the whole nation, affecting both the structure of society and the thoughts and feelings of men ${ }^{120}$.

Historians of the phenomenon of a Christian Socialist revival have tried to solve the problem of delineation in various ways. In his study of Victorian Christian socialists, Edward Norman has chosen to focus on individual thinkers and depicted them as religiously inspired social reformers who were firmly rooted in their own times and circumstances ${ }^{121}$. Paul T. Phillips, in his comparative research on Christian socialism in North America and Britain, has supplemented the more narrowly applied Christian Socialism with the terms social Christianity and social Gospel. By using all three interchangeably, he opened up the meaning of the term to include Christian social action which was not undertaken by declared Christian Socialists, but in contemporary thinking could well have been,

\footnotetext{
116 Stack, David, The first Darwinian left, 2003, p.20-29

117 Hannam, June and Karen Hunt, Socialist women, 2002, p.4

118 Yeo, Stephen, A New Life. The Religion of Socialism in Britain 1883-1896, 1977

119 Carter, Matt, T. H. Green and the development of ethical socialism, 2003

${ }^{120}$ Freeden, Michael, Minutes of the Rainbow Circle, 1989; see Meeting 119, Oct. $2^{\text {Nd }}$, 1907. The Rainbow Circle here follows the French thinker Emile Faguet, to the discussion of whose book "La Socialisme en 1907" they devoted their entire fourteenth session in 1907-08.

121 Norman, Edward, The Victorian Christian socialists, 1987
} 
and frequently was, classified as socialist $^{122}$. Alan Wilkinson and Chris Bryant have tried a patchwork approach by focusing on pinpointing individual persons or groups in a sketchy line of heredity from Charles Gore and Scott Holland to contemporary Christian social activists ${ }^{123}$. Peter d'Alroy Jones, who has written the most comprehensive and detailed study of the Christian Socialist revival period to date, has suggested that the idea of a Christian Socialist movement in the traditional sense should be altogether abandoned. He detects incongruences not only in their respective social, political and economic programmes, but finds fault with the undifferentiated merging of the terms Christian and socialist, and the resulting indiscriminate assumptions about the values and motives behind their social activism for all the various groups and individuals he examined. As a first step towards a more accurate view of Christian social reformism, Jones proposes to differentiate between two kinds of adherents to the intellectual current: between Christian socialists, men and women who derived their political creed from their religious convictions and turned to socialism precisely because they were Christian and considered it the natural outgrowth of their faith, and socialist Christians, men and women who were socialists as well as Christians, but did not usually resort to their religious creed in order to justify their political stance.

\section{The Design of the Thesis}

For the design of this thesis, I have taken up Jones' proposal and extended it by two categories which allow a comparison between religious and non-religious thinkers and might help to shed some light on the particular contribution of Christian social reformers to the re-definition of the social question between 1880 and 1914. To the groups of „Christian socialist“ and „socialist Christian“ I have added the two classes of „,non-Christian socialist“ and ,anti-Christian socialist". In order to distinguish the phenomenon of Christian social reformism which is the subject of examination in the present thesis from the idea of a concerted Christian Socialist movement, I shall from this point onwards refer to it as Christian socialism with a lower case "s", except whenever the thinkers themselves referred to their persons or their ideas as Christian Socialist with a capital "S". In Chapters Two and Three of the thesis, I deal with men who belong to the first of the four

122 Phillips, Paul T., A kingdom on earth, 1996

123 Wilkinson, Alan, Christian socialism, 1998; Bryant, Christopher, Possible dreams, 1996 
categories. The two clerics Stewart Duckworth Headlam and William Booth considered their religion to be the core of their thinking and action. They turned to political activism precisely because they felt that the present social conditions contradicted the tenets of Christianity as they understood it and believed it to be their religious duty to rectify them as far as possible. Chapters Four and Five deal with thinkers who belong to the second group. Henrietta Barnett and Percy Alden both were deeply religious and were moved by the force of their faith to social action. Henrietta Barnett specifically admitted to her Christian motivation. But neither resorted to theological arguments to justify their specific reform proposals or the need for reform.

The four thinkers have thus been chosen to cover both agencies of Christian social action, Christian socialists and socialist Christians. They also belong to various denominations. Stewart Headlam and Henrietta Barnett were both Anglicans. Percy Alden studied to become a Congregationalist minister, and, in 1901, converted to Quakerism. William Booth came from a Methodist background and with his Salvation Army formed one of the most successful denominations of the later nineteenth century. With William Booth and Henrietta Barnett, I have also chosen Christian social reformers who stood outside the formalised tradition of Christian Socialist organisations and fell into a wider category of Christian social activism. With Stewart Headlam, life-long devotee to the Liberal Party, and Percy Alden, who started out as a Liberal and became a member of the Labour Party, I also touch on the various aspects of party political opinion within the social reform movement. Henrietta Barnett represents the point of view of religious women in social activism.

With the thinkers chosen for the non-Christian and anti-Christian categories I have tried to cover a similar breadth of correlated aspects. With Clementina Black and Leo George Chiozza Money, Chapters Six and Seven deal with two thinkers for whom Christianity did not enter either their socialism or, what is more, their private lives, in other words, with non-Christian socialists. Clementina Black was raised an atheist and never gave any indication in her writings that religion, whether Christian or other, played a role in her life. Leo Chiozza Money came from a Jewish background; there is no indication that he was practising. John Mackinnon Robertson, subject of Chapter Eight, represents the category of the anti-Christian socialist. He believed that Christianity held a good deal of responsibility for the present social conditions. For him, the Christian religion constituted a root evil of modern society, standing in the way of progress, and needed to be weeded out in order to reform society and move on to a more harmonious and equitable social order. Robertson was a member of the Liberal Party. So was Chiozza Money who towards the end of his life eventually entered the Labour Party.

The seven thinkers under scrutiny here took part in a nation-wide debate on the social question and 
on how best to secure Britain's future as a cultural, economic and imperial power. Apart from their own, original ideas which they presented in their writings, there ran through their publications various strands of arguments and debates which were at the time current coin and well known to prospective readers. In order to place their contributions to the social question in the context of contemporary thinking, in Chapter One, I will draw out certain of the underlying discussions and ideas which play important parts in the writings of several of the seven thinkers under scrutiny here. I shall also dedicate some space to the institutional setting in which the wider debate on social issues took place and indicate some of the - in John Campbell's term - brokers of the ideas and values which influenced political debate, for instance political parties or public platforms of discussion. 


\section{Chapter 1 - Some Aspects of the Intellectual Context of Late-Victorian and Early-Edwardian Social Reform}

\section{The Intellectual Context and the Contemporary Debate on Social Reform}

In their shared concern for social issues and their dreams of a just and harmonious society, the thinkers of the present study partook in a common stock of ideas, concepts and arguments which made up the intellectual context of social reformism in late-Victorian and early-Edwardian England. The thinkers made their contributions to a widely conducted debate and found themselves influenced, consciously or unconsciously, not only by the proposals and arguments of the other reformers under scrutiny here, but by ideas, intellectual currents and sociological data dominating the larger discourse on social reconstruction. ${ }^{124}$ They quoted the same studies and statistics and responded to the same arguments brought forward in public debates. There is a myriad of connecting underlying strands between the seemingly unrelated publications of the seven reformers under scrutiny here

To give an example, they all read and responded to the scandalous reports on the physical manifestations of destitution, its repercussions on national health and efficiency. The report of 1906 by Dr. Newman, Medical Officer of Health for Finsbury, for instance, which showed a shocking relation between the size of a given tenement and the death rate among its tenants, was invoked by Henrietta Barnett, Percy Alden and Leo Chiozza Money, the three thinkers in the thesis who held a particular interest in housing reform. Alden and Barnett also both referred to the disastrous findings on the physical state of the working classes which came to light during the mustering of recruits for the Boer War. Moreover, they absorbed and discussed the proposals for social improvement which entered the public sphere through newspaper articles or were brought forward in Parliament. Thus, the Liberal reform proposals of Lloyd George's 1906 government figured prominently in the writings of Chiozza Money, John Robertson and Percy Alden.

In the following, I shall focus on some facets of the wider debate on social reform which recur

124 On the influence of overt and covert ideas on political decision taking see e.g. Campbell, John L., Institutional Change and Globalisation, 2004; see Chapter 4 The Problem of Ideas, p. 90 - 123 
regularly in the writings of the thinkers under scrutiny here. One topic which influenced the thought and proposals of all social theorists of the period was the rethinking in economic theory and the changing perceptions of how and to what end the economic machinery functioned.

\section{a) Economics: A Human Science}

In the context of the debate on the nature and definition of Christian socialism, Edward Norman has argued, as we have seen, that the connecting theme of Christian socialism was a rejection of the classical doctrines of political economy and a condemnation of the principle of unlimited competition. It was a critique which many of the thinkers studied here shared. In the face of mass poverty and cyclical unemployment, economists of a new school of political economy began to discredit the principle of non-intervention and to call for a stronger state and more interference in the social and economic spheres ${ }^{125}$.

The view that the mechanisms of the market were not governed by iron laws of nature but controlled and influenced through human activity gained ground in the economic sciences. Economists started to focus on man and his behaviour as an instructive subject of study in search of explanations for the workings of the economic machinery. Among the first to call for such a rethinking of economic theory was the economist William Stanley Jevons ${ }^{126}$. He pioneered the way towards a new approach to the science of economics with the development of his marginal utility theory which he presented in his book The Theory of Political Economy ${ }^{127}$, published in 1871. Jevons argued that economic activity depended not only on the rate of production, a notion propagated by classical economists of the Smith-Ricardian school, but also on consumption. He held that the turnover of goods was determined to a great extent by the relative utility of a given product to the consumer and that the value of such a product originated not only in the costs of production, but also in the rate of demand for $\mathrm{it}^{128}$. A generation later, the famous economist Alfred Marshall summed up the interaction between supply and demand in determining economic activity by comparing them to the two blades of a pair of scissors both of which were indispensable to the action of cutting in his Principles of Economics, a seminal text book of neo-classical economics ${ }^{129}$.

\footnotetext{
125 See e.g. Sidgwick, Henry, The Theory of Political Economy, 1883; Marshall, Alfred, Principles of economics, 1890

126 William Stanley Jevons (1835-1882) was an economic theorist and logician. He is best known in the field of economics for his marginal utility theory of value.

127 Jevons, William Stanley, The Theory of Political Economy, 1871

128 Frankel Paul, Ellen, Moral revolution and economic science : the demise of laissez-faire in nineteenth-century British political economy; 1979, p.230ff

129 Marshall, Alfred, Principles of economics, 1890
} 
By recognising the impact of man's behaviour - i.e. the patterns of consumption - on market activity, the neoclassical political economists as they came to be known re-defined economics as a human science. In his Principles of Economics, Marshall gave the following definition: „Political Economy or economics is a study of the ordinary business of life: it examines that part of individual or social action which is most closely connected with the attainment of the material requisites of well-being. Thus it is on the one side a study of wealth; and on the other, and more important side, a part of the study of man." ${ }^{\text {130 }}$ As a science of man many exponents of the new school of political economy intended to use it in the service of man, trying to discern with its help the best means of achieving well-being for all members of society. The mechanisms of the market lost their attributes as iron laws of nature and, in the hands of social reformers and progressive thinkers, acquired a moral purpose.

One such attempt at employing economics for the well-being of the people was the theory of underconsumption as developed by John Atkinson Hobson and Albert Mummery in The Physiology of Industry (1889) ${ }^{131}$. The theory constituted an attack on the classical assumption that production created demand, and argued that in modern industrial Western society, production tended to outgrow consumption. Hobson and Mummery rejected the Victorian panacea of thrift and argued that, on the contrary, it was by enhancing the purchasing powers of the people and boosting consumption that the economy could be stabilised and growth be ensured. John Mackinnon Robertson arrived at very similar conclusions to Hobson's and Mummery's. His own theory of underconsumption will be examined at length in Chapter Eight of the thesis.

\section{b) The Science of Society: The Rise of Social Enquiry and Typification}

Not only economists discovered man and human behaviour as valuable and insightful objects of research. The thinkers chosen for the present thesis also stood in the tradition of a developing „science of society“, the beginnings of modern-day sociology and social sciences. The emphasis on science and knowledge which had swept over to Britain at the end of the eighteenth century from the continental Enlightenment movement began to impact also on social matters. Intellectuals set themselves the challenge of constructing systems of knowledge about society. The development which took hold during the first decades of the nineteenth century had two aspects to it: some people focused on theorising and the search for explanation of social phenomena, others

\footnotetext{
130 As quoted in Himmelfarb, Gertrude, Poverty and compassion: the moral imagination of the late Victorians, 1991, p. $284 \mathrm{f}$

131 Hobson, John Atkinson and Albert F. Mummery. The Physiology of Industry, 1889
} 
concentrated on the gathering and systematisation of data ${ }^{132}$.

In the latter vein, the expansion of industry and commerce alongside the population explosion of the early nineteenth century offered fascinating subjects for scientific study to the increasingly popular statistical societies in the $1820 \mathrm{~s}$ and $30 \mathrm{~s}$. These societies pioneered the collection and statistical evaluation of data on social developments. A decade or two later, in the former vein, Owenites following the industrialist and social reformer Robert Owen and positivists influenced by the French thinker Auguste Comte claimed to offer scientific systems of explanation for the workings of communal life. Possibly the best known example of a group dedicated to producing taxonomies of social fact and systematising their knowledge about society was the National Association for the Promotion of Social Sciences, known as the Social Sciences Association (SSA). The SSA played an important part in introducing social data and social theories into the sphere of practical politics. The Association used statistical information on a broad range of social questions to discuss and publish policy recommendations. Founded in 1857, the Social Sciences Association experienced its high point during the $1860 \mathrm{~s}$ and $70 \mathrm{~s}$. The organisation sported local societies all over the country. Its central annual conference was attended by amateur social scientists as well as by members of Parliament and the government.

Social research began to acquire a new qualitative dimension with the writings of Henry Mayhew in the 1850s. ${ }^{133}$ His journalistic accounts on working class life gave a mount of detail on the living conditions of the poorer sections of society which had hitherto been unknown to the wealthier strata. Although his work was narrative rather than analytical, Mayhew is commonly credited as forerunner of the pioneering social researchers Charles Booth and Benjamin Seebohm Rowntree whose famous door-to-door surveys in the poor districts of London and York respectively constituted the first systematic gatherings of social data on a large scale and mark an important step towards the development of modern social sciences. Not only did they pioneer the way of systematic social surveying. Their work was also highly influential in the area of typification, classification and the development of models to explain social phenomena. Seebohm Rowntree's model of a poverty cycle, for instance, which he deduced from the material he gathered and which describe the various stages of relative wealth and poverty in a workman's life, is still referred to today. Booth's classification of the poor on the basis of their weekly incomes set standards in the determination of poverty and destitution. His maps of London on which he coloured districts according to the relative wealth or poverty of their inhabitants helped to visualise the extent of mass poverty and to identify those most at risk and most in need of support.

132 Goldman, Lawrence, Science, reform and politics in Victorian Britain : the Social Science Association, 1857-1886, 2002

133 Freeman, Mark, Social investigation and rural England, 1870-1914, 2003, see esp. p.5-7 
At least three of the thinkers in the present thesis, namely Clementina Black, Leo Chiozza Money and Percy Alden, were greatly influenced in their work by the new quest for a social science and the development of social statistics. Most obviously, Clementina Black stood in the tradition of Booth and Rowntree. Her study The Makers of Our Clothes, which she published co-jointly with Mrs. C. Meyer in 1909 and which forms a key-source of this study, is based on a survey among women employed in sweated trades in the East End. Black and a brigade of co-workers conducted standardised interviews with female labourers as well as experts such as local clerics and social workers using a questionnaire modelled in form on those of Booth and Rowntree. The questionnaire was published as an appendix to the book.

While Black collected original data, Leo George Chiozza Money and Percy Alden dedicated themselves to the development of generalised models and the systematisation and typification of social phenomena. In his book Riches and Poverty, which will be examined in Chapter Seven of this study, Chiozza Money used data collected by the government for purposes unrelated to the social question - namely data on death duties and on the income tax - to calculate average incomes and to construct a model of wealth distribution across the entire population. By this method he brought home to the public the fact that the maldistribution of property was even more pronounced and dramatic than Charles Booth's and Rowntree's surveys of industrial cities had suggested.

Percy Alden's contribution to a scientific approach to the problem of poverty lay in the systematisation of unemployment and his formulation of a typology. He was among the first to differentiate carefully between the underlying causes of the various kinds of unemployment and formulated policy proposals for a solution to the problem on the basis of such causes as well as of the number of people concerned. His book The Unemployed. A National Question shall be analysed in Chapter Five of this thesis.

c) The Quest for National Efficiency

One factor which influenced the movement for social reform which we have not yet mentioned was the atmosphere of intense international rivalry in economics and the military sphere which led up to the First World War.

After the phenomenal rate of industrialisation in Britain in the first half of the nineteenth century, from about mid-century onwards, the rate of economic growth slowed considerably. Contemporaries experienced this slowing down as a severe recession, and the relative decline in economic expansion, domestic as well as foreign, which became increasingly noticeable from the 
1870s onwards, constituted a major cause of concern. The growing competition from industrialising nations such as Germany and the US threatened Britain's economic hegemony. Fears of a loss of international competitiveness were reinforced by military disasters as in the Crimean Wars (1851 1854) and, more notably still, during the Boer Wars (1899 - 1902). "Mournful Monday" and "Black Week" in December 1899, two severe defeats in South Africa which cost the British dearly in terms of manpower as well as equipment, caused a major discussion on the adequacy, or rather inadequacy, of the British army. The disastrous physical condition of certain strata of society which the mustering of volunteers for military service had brought to light during the Boer Wars added to the public anxiety that the British Empire may have passed her prime and that revolutionary changes were required to safeguard, or rather to re-conquer, her status of international supremacy.

One strand in the discussion on the causes of and remedies for Britain's threatened position as leading economic and military power was a debate on ,national efficiency“ which permeated all shades of progressive opinion ${ }^{134}$. Asserters of national efficiency began to criticise the principle of laissez-faire which they detected not only in the economic sphere, but also in the set-up of the political machinery and in the workings of society more generally. For them, the tenet of nonintervention constituted a maxim of amateurism and a renunciation of control. In the eyes of advocates of national efficiency, Britain compared unfavourably, for instance, with Germany which had professionalised all areas of public service and administration, from the army to the civil service, and had in a very short time become Britain's main rival in Europe, economically as well as in the military sphere. By comparison, the journalist Charles Brodrick marked critically in an article for the magazine Nineteenth Century in October 1900, Britain constituted a "nation of amateurs", her government run by men who had been trained in fair play and goodwill on the playing fields of Eton, but had no expertise and know-how in the art of running a nation ${ }^{135}$. The Fabians, for example, were among those who showed themselves particularly interested in national efficiency, as did some of the New Liberal reformers.

A large part of the national efficiency movement focused on administrative reform, aiming at professionalising the civil service as well as central and local government. But the argument was also employed in the interest of social reform. One such area in which the quest for national efficiency was played out particularly strongly was the reform of the educational system. Educational reformers pointed to Germany who sported a superior system of technical and scientific education. Her well-trained workforce, they pointed out, enabled Germany to rapidly overtake

\footnotetext{
134 The information and arguments used in the following section are taken from Searle, Geoffrey Russell, The Quest for national efficiency, 1971; see also Wiener, Martin J., English culture and the decline of the industrial spirit, 18501980, 1981

135 Searle, Geoffrey Russell, The Quest for national efficiency, 1971
} 
Britain in industries such as optical glasses or the chemical industries which required scientific knowledge and superior workmanship. Advocates of national efficiency demanded improvements in the British system of education, elementary, secondary and higher, calling for a comprehensive training of the British workforce not only the in the basic skills of reading, writing and arithmetic, but also in technical and scientific subjects in order to keep pace with Britain's international rivals. In the framework of the present thesis, it is Leo George Chiozza Money who showed himself most explicitly concerned about the inferiority of the British schooling system. His reports on visits to German educational institutions feature, among other texts, in Chapter Seven of this thesis.

Other reformers were concerned about the loss of industrial efficiency which resulted from the corroded health and inferior physique among large sections of the British working classes. They quoted surveys which had shown the German workforce, even the very poor, to be in better physical shape than the average British slum dweller. Some attributed this to Bismarck's social security system which insured the worker against contingencies such as accidents, sickness and unemployment. In the interest of international competitiveness, they demanded a like system for Britain in order to keep the worker in sound health and in a state of efficiency even in periods of joblessness or illness. Of the thinkers under scrutiny here, Henrietta Barnett employed the argument on industrial efficiency most explicitly. But the idea permeated also the thought of, for instance, Percy Alden and Clementina Black.

d) A Critique of Modernity and the Myth of the Countryside

Other reformers felt drawn to a vision of society which was diametrically opposed to the quest for efficiency. They believed that by embarking on a course of full-scale industrialisation and urbanisation, Britain had taken a wrong turn. While some contemporaries considered the industrial city to be an emblem of progress and culture and the factory a symbol of future wealth, they were critical of the extent of urbanisation and the rapid large-scale switch to industrial forms of production and employment. They blamed the problems of mass unemployment, urban overcrowding and a declining national physique directly on the changes in the economic set-up of Britain, disregarding or at-least down-playing other contributory factors such as the influx of cheap grain from the United States. To varying extents, they sought a return to a pre-industrial, or in some cases as for instance the Guild Socialists ${ }^{136}$, a post-industrial form of social and economic

136 Jones, Peter d'Alroy, The Christian socialist revival 1877 - 1914. Religion, class, and social conscience in lateVictorian England, 1968, p.275-95 
organisation.

Aesthetics and health risks constituted the main points of criticism for those who worried about the effects of large-scale urbanisation. In Building Jerusalem, the historian Tristram Hunt has forcefully reminded his readers of the unpleasant and dangerous sides of the Victorian city. The nineteenth century saw an unprecedented rate of urban growth. In 1700, eighteen percent of the British population had lived in towns. By 1851, their proportion had risen to fifty-four percent. During the same period, the overall size of population in England and Wales tripled from 5.58 million people in 1741 to 16.74 million Britons in 1851 . The sheer number of people migrating to the industrial centres let them swell to unprecedented size. In 1801, London was the only town containing more than 100.000 inhabitants. Fifty years later, there were seven such centres of population, and by 1901 , there existed nearly thirty towns of 100.000 dwellers or over. ${ }^{137}$ London continued to occupy an exceptional place as the largest city of the empire, and soon to be the largest city in the world. In 1851, 2.5 million people lived in the metropolis. By 1871, the city had grown to 3.9 million inhabitants, and by the year of Victoria's death, 1901, London housed 6.5 million people. Almost one fifth of the entire population of England and Wales resided in the capital by the turn of the century $^{138}$.

Most migrants to the city were poor farm hands in the frequently vain search of employment. In the main, urban growth thus signified a growth of poor neighbourhoods and an increase in overcrowded districts. In the early decades of the nineteenth century, life expectancy in the towns undercut the average length of life in the country by a very wide margin. In the overcrowded, undersanitised, sun- and airless streets of poor neighbourhoods, contagious diseases like typhoid, tuberculosis, whooping cough or cholera flourished and gave the impression that urban habitation as such was detrimental to human health. Some contemporaries began to fear that there grew up a new race of physically degenerate Britons in the poor city neighbourhoods who, due to a lack of proper nutrition, sunlight, clean air and physical exercise, depressed the general standard of the nation ${ }^{139}$.

Some also objected to the industrial form of employment. They pointed to the physical harm done by long hours of heavy or dangerous work in factories or overcrowded workshops. Repetitive strenuous work at machines caused multiple forms of injury from strain. Children suffered serious deformities due to too heavy physical work too early in life. Others succumbed to diseases from exhaustion. Workers at cotton and wool mills who spent the day in hot and humid conditions frequently fell ill with consumption. Some illnesses were so common among industrial labourers that they became associated by name with specific forms of employment. Anthrax, for instance,

\footnotetext{
137 Harris, Bernard, The origins of the British welfare state, 2004, p.31

138 Hunt, Tristram, Building Jerusalem: the rise and fall of the Victorian city, 2004, p.287f

139 Hunt, Tristram, Building Jerusalem: the rise and fall of the Victorian city, 2004, p.25ff
} 
which was imported in sacks and containers of raw cotton from the USA and India became known as "wool sorters' disease". "Phossy jaws" among match girls and led-poisoning among glazers were common occurrences.

Critics of industrialisation also demurred to the high level of fragmentation of industrial work which left the individual with but a tiny part of the process necessary for an article's production to perform. Clothes' manufactures, for instance, employed a variety of designers, cutters, bodicemakers, seamstresses, buttonholers, embroiderers and girls who did the pressing. Such highly fragmented work was uninspiring and unsatisfactory, some conjectured, robbing the labourer of the interest he or she could take in the various stages of production, the pride in one's skill and the satisfaction of holding a finished product in one's hands ${ }^{140}$.

John Ruskin and William Morris formulated prominent protests against what they perceived as soulless industrialism ${ }^{141}$. They both objected to the modern form of employment on aesthetic grounds. Ruskin lamented the stultifying effects of mechanical labour and the ugliness of factories, rail roads and the newly grown urban centres of modern England. He called for a return to the small workshops which blended in with village architecture and caused little pollution and advocated methods of production where men laboured co-operatively and took pride in their work. William Morris' Arts and Crafts Movement ${ }^{142}$ followed similar lines. It committed itself to a set of rules which forbade the use of machinery for mass production and demanded that every object produced be aesthetically pleasing.

Their writings, Ruskin's aesthetic protest against industrial society in, for instance, Unto This Last ${ }^{143}$ and William Morris' utopian novel News from Nowhere ${ }^{144}$ found a wide audience among reformist thinkers in the second half of the nineteenth century. The writers' criticism of the new set of values which had in their eyes taken over in modern industrialised society, namely those of commercialism, profitability and utility, touched a nerve with many contemporaries. ${ }^{145}$ As we shall see in Chapter Three of this thesis, William Booth voiced similar criticism of industrialised forms of employment in his book In Darkest England and the Way Out.

Both critics of urban forms of living and of industrial employment frequently found their solutions in retrospection. Several members of both groups shared a belief in the beneficial aspects of country

140 Marsh, Jan, Back to the land, 1982, p.139-170

141 Marsh, Jan, Back to the land, 1982, p.12-22

142 Marsh, Jan, Back to the land, 1982, p.142

143 Ruskin, John, Unto This Last, 1862; John Ruskin (1819 - 1900) was an art critic, artist, social theorist and author. His prolific publishing made him a prime exponent of sage writing, a genre of creative non-fiction in which the writer instructs and chastises the reader over contemporary social issues which was popular in the Victorian era. Other sage writers include, for instance, Thomas Carlyle (see above).

144 Morris, William, News from Nowhere, 1890; William Morris (1834 - 1896) was a social critic, architect and designer, an associate of the Pre-Raphaelites and a proponent of the Arts and Crafts Movement.

145 Hunt, Tristram, Building Jerusalem: the rise and fall of the Victorian city, 2004, p.57-96 
life and the regenerative effects of farm labour and gardening. Edward Carpenter, besides Ruskin and Morris possibly the most prominent critic of industrialism in the Victorian era, carried the belief to its extremes. Carpenter withdrew from Victorian urban society and became a self-sustaining recluse in Millthorpe, Derbyshire, growing his own food and weaving his own clothes. The period saw a myriad of experiments at alternative ways of living: St. George's Farm at Totley outside Sheffield, founded by John Ruskin, the Clowsden Hill Communist and Cooperative Colony or the cooperative farm at Purleigh, for instance, all housed agrarian and artisan communities which rejected industrial society and tried to be self-sufficient ${ }^{146}$.

Many reformers viewed the more extreme teachings of Ruskin and Carpenter with indecision or even distaste, but several believed that the solution to the modern problem of mass unemployment did indeed lie in a re-enforcement of the agrarian sector. Local Poor Law authorities tried out various re-settlement schemes which aimed at relocating the urban unemployed to the depopulated countryside. Most famous among them was probably the Poplar Union farm colony at Laindon in Essex which opened with the financial assistance of the American George Fels in $1904^{147}$. The Mansion House Fund sponsored a farm colony for the London unemployed in $1886^{148}$. Behind the scheme stood, among other things, the idea that with rural de-population, arable land was in plentiful supply. Many supporters of labour colonies hoped that with a return to a strong agricultural element in her economy, Britain could shake off her increasing dependence on imports of grain and other food stuff from the US and the colonies. Within the framework of the present thesis, farm colonies played a major part in the thought, for instance, of William Booth and Percy Alden.

Some tried to reconcile a belief in the beneficial effects of tilling the land with the realities of urbanised industrial society: campaigns like Joseph Chamberlain's famous demand for "Three Acres and A Cow" to be made available to every working man in the country bear witness to this ideological balancing act $^{149}$. The Liberal MP and erstwhile Mayor of Birmingham Chamberlain argued in his Radical Programme of 1885 that not only the unemployed would benefit from ploughing, harvesting, and growing their food, but that such work would improve the physique and morale - of the entire working class of Great Britain. He could point to successful housing experiments and model industrial villages such as Titus Salt's Saltaire, the Lever brothers' Port Sunlight or George Cadbury's Bournville. These entrepreneurs had built settlements for their workers in the immediate vicinity of their factories providing reasonably spacious cottages with

\footnotetext{
${ }_{146}$ Marsh, Jan, Back to the land, 1982, p.94-101

147 Harris, Jose, Unemployment and politics, 1972, p.139f

148 Harris, Jose, Unemployment and politics, 1972, p.111ff.

149 On Chamberlain's plans for housing reform see e. g. Hunt, Tristram, Building Jerusalem: the rise and fall of the Victorian city, 2004, p.254-261; see also Gould, Peter C., Early green politics: back to nature, back to the land, and socialism in Britain, 1880-1900, 1988.
} 
private gardens at affordable rents. The industrialists insisted that the investment paid off as the inhabitants of their tenements were in markedly better shape and more efficient than the slum dwellers of the nearby cities.

The economist Alfred Marshall recommended in an article for the Contemporary Review in 1884 to re-settle large sections of the working classes in such industrial colonies. London, he argued, was beyond rescue, and the money spent on re-housing the poor in inner city housing projects would be more effectively and profitably spent on founding new industrial communities of the type already successfully run at Saltaire or Bournville ${ }^{150}$. Such model villages also provided the blueprints for housing experiments undertaken by the Garden City and Garden Suburb movements. The latter aimed not only at providing the working classes with a private plot of land to supplement their incomes. Garden city campaigners also pointed to the tight social networks and the ties of mutual responsibilities which in their eyes had marked the pre-industrial village. Their housing schemes, such as for instance Henrietta Barnett's Hampstead Garden Suburb, aimed at re-constructing such a true community of classes and a healthy environment for even the poorest workers ${ }^{151}$.

\section{e) Land Reform}

A school of thought which occasionally overlapped with the back-to-the-land movement were the land reformers. Land reformers objected to the unjust distribution of private possession in land in Great Britain. A survey in 1876 had shown that there were about a million landowners in Britain, of which 300.000 had possession of the vast majority of available land ${ }^{152}$. For land reformers, the relative fewness of landowners equated to a quasi-monopoly in what they considered to be the main means of production.

Some, such as the Land Nationalisation Society, called into question the legitimacy of private possession of so common a good as the soil and campaigned for the public appropriation, or nationalisation, of the soil. Others feared the complicated legal problems involved in expropriation and tried to shun issues such as compensation by appropriating not the land itself, but the profits derived from its use through a tax on land values. The prophet of land reform of the latter kind was

\footnotetext{
150 As quoted in Hunt, Tristram, Building Jerusalem: the rise and fall of the Victorian city, 2004, p.300f

151 On the garden city movement see for instance, Meacham, Standish, Regaining paradise. Englishness and the early garden city movement, 1999

152 Gould, Peter C., Early green politics: back to nature, back to the land, and socialism in Britain,1880-1900, 1988, p.13
} 
the American Henry George ${ }^{153}$. In his book Progress and Poverty ${ }^{154}$, first published in the USA in 1879 and in Britain in 1881, George traced the current problems of poverty and destitution to an inherently unjust monopoly in land held by a minority of the rich. An ardent Christian, George argued that the land was bestowed upon mankind by God for their maintenance and common good. No power upon earth could confer private possession and exclusive use of it upon individuals.

As he foresaw difficulties in disowning landlords who had often held the land for generations, George settled on taxing away the whole of the value of the land. Such value was more often than not the product of communal industry and social enterprise rather than of individual initiative, he argued, and thus rightfully belonged to the community which created it. The American envisaged that in the long run, the tax on land values would be sufficient to cover all state expenses and argued that all other forms of taxation, especially indirect rates such as taxes on food, be abolished. In Britain, the idea of a Single Tax on land values was eagerly taken up by, for instance, the English Land Restoration League, founded in 1884. Georgeism formed a central influence upon many progressive and socialist strands of thought in the last decades of the nineteenth century, among them sections of the Fabian Society, the Marxist Social Democratic Federation and New Liberalism. Percy Alden and John Mackinnon Robertson both embraced it to varying degrees. The most ardent supporter of Georgeist land reform in the present study, and a founder member of the English Land Restoration League, was Stewart Headlam.

The changing concept of economics and the emergence of a science of society, the quest for national efficiency and the critique of modern forms of living and working which we have heard about in the foregoing paragraphs formed part of the joint stock of ideas, arguments and questions in which the thinkers examined in the present study partook. But besides these intellectual overlappings, they also shared their platforms for discussion and met in the same political groups and similar social circles as we shall see in the following section.

\section{The Political Setting: New Liberalism, Fabianism and the Rainbow Circle as Examples of the Institutionalised Progressive Movement}

The thinkers chosen for the present study only occasionally quoted each others' writings directly. Stewart Headlam, for example, referred to Leo George Chiozza Money's charts on the unequal

153 Henry George (1839-1897), was an American economist and social reformer.

154 George, Henry, Progress and poverty, 1881 
distribution of wealth in Britain which he published in Riches and Poverty in 1905. Percy Alden and John Robertson appraised William Booth's scheme of Salvation Army farm colonies with which the latter proposed to solve the problem of unemployment. Alden, an expert on questions of labour, applauded Booth's nation-wide system of labour bureaux which served as points of contact and information for both employers and unemployed. But in the material studied here they did not discuss each other's proposals in any detail.

However, working on similar issues at a similar time in London, the thinkers did, of course know each other and worked together on various political and social bodies. They formed part of the London-based progressive intelligentsia which mixed and mingled in various groups and circles working towards social reform. To give some examples, Percy Alden, Stewart Headlam, Leo Chiozza Money and John Robertson, for instance, were active members of the Liberal Party. Headlam, Alden and Clementina Black belonged to or, in the case of Black and Robertson, worked with the Fabian Society. Headlam and Alden also sat on the London School Board for overlapping terms. Alden and Henrietta Barnett were both deeply involved in the Settlement Movement which aimed at drawing university graduates to social work in the London East End. Alden was also a member of the Rainbow Circle, a discussion group of progressives from across the political spectrum on issues of social, economic and political reform. So was John Robertson. Chiozza Money served as a member of the Select Committee on Home Work in 1907 and 1908, and in this capacity can be assumed to have met Clementina Black, a leading propagandist on sweated trades and one of the organisers of the Sweated Industries Exhibition of 1906 which helped to bring about the governmental inquiry of the Select Committee. It can thus be safely assumed that the writers studied here discussed each others' ideas and policy proposals in miscellaneous contexts.

To look at all the bodies, in John Campbel's term the "brokers of ideas and values"155, which the thinkers under scrutiny utilised to develop and realise their ideas would mean to go far beyond the scope of this study. To give the reader an idea about the nature and workings of such organisations, in the following I present in some more detail three of the arguably most formative political groups in which several of the reformers discussed here met, and which historians judged to have been highly influential in both practical politics as well as the public debate on social issues.

155 On the role of brokers in decision taking debates see e.g. Campbell, John L., Institutional Change and Globalisation, 2004, p. $90-123$ 


\section{a) The Liberal Party}

In the absence of a separate Labour Party until 1906, the most obvious platform for socially progressive thinkers to meet was the Liberal Party. As we have heard above, Headlam, Alden, Chiozza Money and Robertson were all members of it. Alden, Money and Robertson were returned to Parliament in the Liberal landslide of 1906. All considered themselves part of the party's reform wing of New Liberalism which gained influence within the party over the last decade of the nineteenth century and eventually came to power with the Liberal governments of Herbert Asquith and David Lloyd George in the first decade of the twentieth century.

The historian Michael Freeden has described New Liberalism as an attempt to modernise the Liberal Party from within. The reform movement aimed to adapt the classical Liberal world view with its paramount emphasis on individual liberty and self-dependence to the intellectual and material environment of fin-de-siècle Britain ${ }^{156}$. In the eyes of many members of the Liberal Party, the tenets of laissez-faire and individualism had disproved themselves in the course of industrialisation. Urban mass poverty brought home to them very forcefully that environment could stand in the way of personal liberty and that social and material conditions could hinder the individual in his or her free development. New Liberals therefore abandoned the classical Liberal definition of liberty as the absence of restraint. They re-defined freedom as a positive capacity, as a state of empowerment which allowed the individual to fulfil his or her potential.

New Liberals began to conceive of the individual not as an absolute, but as a member and a unit of a social community ${ }^{157}$. They believed that society formed a collective where each member depended upon the others. Apart from his or her personal well-being, they argued, individuals held an inherent interest in the welfare of all: only if the community at large was healthy could the individual hope to strive. To the time-honoured tenet of individual liberty New Liberals thus added the new value of a „,common good“ to the Liberal Party's ideology, a communally shared interest in the well-being and progress of society. The idea that the health and growth of the national community constituted a goal in its own right fell on fertile ground at a time when fierce international competition in the economic and military sectors, especially from Germany and the United States, threatened Britain's hegemonic position in Europe and the Western world.

The newly introduced tenet of a common good prompted New Liberals to view governmental interference as a potentially advantageous force ${ }^{158}$. The state became an agent of welfare and a guardian of the interests of the individual as well as of society and the nation at large. This

156 Freeden, Michael, New liberalism: an ideology of social reform, 1978

157 Weinstein, David, Utiliarianism and the New Liberalism, 2007; esp. Part II The New Utilitarians

158 Freeden, Michael, New liberalism: an ideology of social reform, 1978 
rethinking of the state as safeguard of individual and communal well-being, as an active player in social and economic politics, was possibly facilitated, Freeden suggests, through the spreading in the last third of the nineteenth century of municipal socialism. In Birmingham, the city's mayor Joseph Chamberlain had municipalised the gas, water and milk trades and brought libraries, public parks and galleries under communal management. He had thereby provided his contemporaries with a practical example of how municipal ownership and communal control of key trades could contribute to an improved standard of living and increase the well-being of large sections of the city's population. The example of Birmingham and several other municipalities which followed in its footsteps probably helped to lessen the fears of many Liberals of a strong and active state.

Michael Freeden stressed that New Liberalism constituted not a break with old doctrine, but a development and continuation of it. It was in keeping with the old emphasis on individual freedom (in its re-defined, positive interpretation) and personal capacity, he argued, that New Liberal social reform focused on redistributive measures. The party's reform wing stated that laissez-faire had led to a maldistribution of wealth, which had resulted in mass poverty and had thereby abridged the freedom of the majority. Curtailing the worst excesses of laissez-faire by putting at everyone's disposal the material means necessary for a decent life seemed to New Liberals to constitute the most promising path towards true liberty for all members of society.

A field of action presented itself, for instance, in the form of land reform. The idea of an unearned increment tax on land in particular appealed to New Liberals: the definition of rent as unearned helped to circumvent the complicated issue of private property. Arguably the most revolutionary and zealous attempts at New Liberal social reform were, however, Lloyd George's redistributive People's Budget of 1909 which proposed to impose heavy taxes on the wealthy, as well as his extensive insurance schemes and the introduction of old age pensions. As member of various Select Committees, among them the Select Committee on Home Work, and as close advisor of David Lloyd George, one might assume that Chiozza Money had a hand in the drafting of some of the New Liberal policy proposals on social reform.

\section{b) The Fabian Society}

Another major force in the progressive landscape of turn-of-the-century Britain was the Fabian Society ${ }^{159}$. Among the thinkers studied in this thesis, Stewart Headlam and Percy Alden both

159 For background information on the Fabian Society see e.g. Beilharz, Peter and Chris Nyland (eds.), The Webbs, Fabianism and Feminism: Fabianism and the political economy of everyday life, 1998; Beilharz, Peter, Labour's utopias: Bolshevism, Fabianism, Social Democracy, 1992; Hill, Clive E., Understanding the „Fabian Essays in 
belonged to the Fabian Society; Clementina Black and John Robertson hovered on its edges. Headlam even served three terms on the Society's executive between 1890 and 1911.

The Fabian Society, founded in 1884, named itself after the antique Roman general Quintus Fabius Maximus, nicknamed „The Delayer“, who in the war against Hannibal had refrained from direct attack and opted for a strategy of gradual attrition against the Carthaginian army. The Fabian Society propagated the same approach towards the evils of industrialised society. It placed itself in direct opposition to the Marxist Social Democratic Federation, formed some three years earlier in 1881, which advocated class war and a violent revolutionary upheaval of the suppressed proletariat. By contrast, the Fabian Society aimed at a peaceful, gradual, evolutionary reform of society through existing social and political institutions towards more equitable and just conditions for all. Its emphasis on evolutionary socialism exercised a wide appeal to social reformers in turn-of-thecentury Britain and is reflected in the thought of a number of the thinkers discussed here.

The group was an outgrowth of the Fellowship of the New Life which had been founded in 1883 by a band of London-based intellectuals who pledged themselves to a simplified life in order to set an example for society. When some members wanted to become politically involved to fasten the reconstruction of society, they formed the Fabian Society. The Society expressly defined itself not as a political party, but as an intellectual discussion group. However, its immense influence over British politics in the period before the First World War is undisputed. Through overlapping membership Fabianism infiltrated the New Liberal wing of the Liberal Party as well as, at a later stage, the Labour Party. From its inception the Society drew numerous notable members, among them the writers George Bernard Shaw, H.G. Wells, Leonard and Virginia Woolf, the future Labour Prime Minister Ramsay MacDonald and the suffragette Emmeline Pankhurst. At the centre of the Society stood Sidney and Beatrice $\mathrm{Webb}^{160}$ who jointly wrote extensive works on the issue of industrial relations and economic organisation and made important contributions to the political and economic theory of the co-operative movement.

Apart from its membership Fabianism owed its widespread influence also to the prolific publicising of its adherents. In irregular intervals, the Society published contributions to various topics of social, political and economic organisation or to the philosophy of social reform, the so-called

Socialism“(1889), 1996

160 Sidney Webb (1859-1947) and Beatrice Webb, née Potter (1858-1943), were economists, sociologists and social reformers. They were early members of the Fabian Society and through their influential writings, for instance on the cooperative movement, trade unionism and the Poor Law, came to dominate its debates and its public perception, although there continued to co-exist various positions on social questions within the society. Using a bequest to the Fabian Society, the Webbs together with other Fabians set up the London School of Economics in 1895. They served on the Royal Commission on the Poor Law which was set up in 1905 and were responsible for the Commission's allegedly collectivist Minority Report. In the 1930s, the Webbs stirred up controversy through their favourable writings on the Soviet Union and its nationalised economy. 
Fabian Tracts ${ }^{161}$. Before 1914, there had appeared roughly 175 such articles. Stewart Headlam, for example, contributed two tracts on the relationship between Christian beliefs and social reform entitled Christian Socialism ${ }^{162}$ and Socialism and Religion ${ }^{163}$. But the Fabian Tracts were too varied in content and subject matter and bore too much the imprint of their respective authors to provide a clear picture of the programmatic stance of Fabianism on social and political questions.

In the first two decades of its existence, the Society undertook several attempts to give itself a political programme. In 1885, the Society's executive, among them Stewart Headlam, formulated a programmatic Basis which was meant to end the confusion over the group's political stance. In 1889 , the Society followed up with the publication of a collection of articles called Fabian Essays in Socialism ${ }^{164}$ which pursued the dual aim of making available to the public the outcomes of some of the internal debates at the Society's regular meetings as well as to help define a Fabian stand in questions of social reform. But the Fabian Essays suffered from the same defect as did the Fabian Tracts: due to the diversity of the thinkers who published under the Fabian banner, the exact contents and delineations of Fabian ideology remained hazy. The one distinguishing feature of Fabianism, and probably its greatest contribution to the British progressive movement, thus remained its emphasis on gradualism.

Despite its lack of a clear programmatic profile, the Fabian Society fared well and is today associated to the Labour Party, functioning as a progressive think tank on social and political questions for the party.

\section{c) The Rainbow Circle}

There existed yet another group which offered a platform for debate and intellectual exchange on social and political questions and served as a multiplier of reformist ideas with far-reaching influence: the Rainbow Circle. By contrast to the Fabian Society which in the first decades of its existence set itself the aim, however unsuccessfully, of developing a corporate identity and a concerted programme, the Rainbow Circle perceived itself from the start not as a political collective, but as an ideologically impartial meeting place for intellectuals from all shades of progressive opinion. The Circle refrained from publishing political tracts under its banner or from

\footnotetext{
161 See e. g. Fabian Society, Fabian Tracts Nos. 1-186, 1918

162 Headlam, Stewart Duckworth, Christian Socialism: a lecture, Fabian Tract No 42, 1892

163 Headlam, Stewart Duckworth, Socialism and Religion, 1907, republished in Socialism and Religion by the Rev. Stewart Duckworth Headlam, the Rev. Percy Dearmer, the Rev. John Clifford, \& John Woolman. Fabian Socialist Series No 1, 1908

164 Fabian Essays in Socialism, ed. George Bernard Shaw, 1889
} 
making the outcomes of their meetings known to a wider public. Yet, its high-calibre members carried the ideas formed and tested in the course of the Circle's discussions into their professions as journalists, civil servants, governmental office holders or business men and thereby ensured the Circle's widespread influence. Percy Alden and John Mackinnon Robertson from among the thinkers examined here met regularly on this platform.

The Rainbow Circle had its origins in the discontent of a number of radicals at the forefront of progressive thought who lamented the absence of a platform for open and impartial exchange between members of various reformist groups and parties. In 1893, they therefore joined up for a series of free discussions on social and economic issues at the National Liberal Club. The meeting marked the birth of what Michael Freeden has called one of the most cohesive, broad-minded and progressive discussion groups of the nineteenth and twentieth centuries ${ }^{165}$. The group met on a monthly basis and comprised about thirty members. Among them were some of the most notable and influential figures of political and intellectual life of the period - for instance the future Prime Minister Ramsay MacDonald, the economist John Atkinson Hobson and William Pember Reeves, the New Zealand Minister of Labour and author of the 1894 Industrial Conciliation and Arbitration Act which will play a part in the discussion on Clementina Black's social thought in Chapter Six.

The Circle never initiated concrete reform programmes, but considered itself a platform for intellectual exchange. As such, it could accommodate ideas and opinions from a wide range of progressive sources. Many of its members sat in Parliament for the Liberal Party, among them, as we have seen, Alden and Robertson. There was an overlap in membership also between the Fabian Society and the Rainbow Circle. The Ethical Movement, too, was an important source of inspiration for the Circle's debates ${ }^{166}$. As a result of the varied backgrounds of its members, the group discussed an exceptionally wide range of topics. As broad and far-reaching their intellectual horizon may have been, however, on some (though by far not all) subjects discussed the Circle formed definitive opinions: it showed itself strongly in favour of the organisation of labour in trade unions, forced if necessary ${ }^{167}$, and the co-operative movement. It recommended introducing a minimum wage. The Circle advocated governmental interference in the interest of communal welfare and saw the state as potential owner of land and industry.

The aim of the Rainbow Circle was, however, not the issuing of a joint political programme, but the open debate of ideas among men of various backgrounds. Alden, for instance, used the platform to test his ideas on the contribution which the co-operative movement could make to the evolution of a truly socialist society and to propagate an extension of the jurisdictions and authority of local

\footnotetext{
165 Freeden, Michael, Minutes of the Rainbow Circle 1894-1924, 1989, see esp. Introduction

166 See Freeden, Michael, Minutes of the Rainbow Circle 1894-1924, 1989; see Introduction

167 Freeden, Michael, Minutes of the Rainbow Circle 1894-1924, 1989; see Meeting 233, May $14^{\text {th }}, 1919$
} 
government $^{168}$. Throughout his long membership, John Robertson spoke regularly at the Circle's meetings, frequently on questions relating to the Empire and on the topic of taxation ${ }^{169}$. In 1909, he provoked a highly controversial debate among the Circle's members when he presented his views on Malthusianism and argued that in the absence of natural checks against the growth of the human population, social reformers had to embrace the cause of birth control ${ }^{170}$. Robertson's views on population control will be discussed in more detail in Chapter Eight of this study.

Of particular interest for the present thesis are the records of the Circle's fourteenth session in 1907/08. The meetings of that year were devoted entirely to discussions on various interpretations of socialism. The Circle agreed that modern society compared to the human body where each cell depended on the others for its own survival. By contrast to classical Liberal doctrine which had seen the individual as absolute and granted it certain rights against society, the Circle believed that a person could hold rights only within, and never in opposition to society. The ultimate aim of social life lay, in the Circle's eyes, in the promotion of communal, not just individual, welfare and in the attainment of a common good. The challenge in the Circle's opinion lay in reprogramming public opinion and changing the structure of social institutions to recognise this. The members detected in socialism a broad movement of thought and action which set out to achieve this. As we have seen in the Introduction, the Circle's definition of socialism comprised "every tendency having for its object real equality among men", affecting the actual structure of society on one hand and the thoughts and feelings of men on the other, with the aim of re-organising society along the lines of mutual dependence and cooperation ${ }^{171}$. The members of the Rainbow Circle agreed during their discussions in 1907/08 that the changes in public opinion and political practice in latter years constituted important steps towards the achievement of this goal. They welcomed what they perceived as the „beginnings of a conscious use of social power for social good“172.

Within this shared framework of ideas and arguments as well as of political parties and social action groups, the seven thinkers chosen for this study developed their individual programmes of social reform. Their motives for social activism, their understanding of society, the state and the individual, their perception of how the economic machinery functions and their reform proposals form the subjects of the following seven chapters. The first thinker to be examined in detail is the

\footnotetext{
168 See for instance Freeden, Michael, Minutes of the Rainbow Circle 1894-1924, 1989; see Meeting 123, Feb. $5^{\text {th }} 1908$ and Meeting 146, May $4^{\text {th }} 1910$

169 See for instance Freeden Michael, Minutes of the Rainbow Circle 1894-1924, 1989; see Meeting 47,Oct. $4^{\text {th }}, 1899$ and Meeting 104, Feb. $7^{\text {th }}, 1906$

170 Freeden, Michael, Minutes of the Rainbow Circle 1894-1924, 1989; see Meeting 134, Feb. $3^{\text {rd }}, 1909$

171 Freeden, Michael, Minutes of the Rainbow Circle 1894-1924, 1989; see Meeting 119, Oct. 2 ${ }^{\text {nd }}$, 1907; for the particulars of the debates of the Rainbow Circle on socialism see minutes of the Fourteenth Session 1907/08

172 Freeden, Michael, Minutes of the Rainbow Circle 1894-1924, 1989; see Meeting 119, Oct. $2^{\text {nd }}, 1907$
} 
Christian socialist Stewart Duckworth Headlam, an Anglican divine who drew his motivation and argumentation for social reform from his religious faith. 


\section{Part II}

Debating Poverty:

The Thinkers and

their Arguments 


\section{A. Christian Socialists}

\section{Chapter 2 - Stewart Duckworth Headlam and the Socialist Message of Christ}

\section{Biographical Data: Stewart Headlam}

Stewart Duckworth Headlam was born at Wavertree near Liverpool on January 12, 1847. He spent his childhood in a home marked by his father's evangelicalism. The latter's strict sabbatarianism and his frequent rages against alcohol, card games and the theatre impressed upon the young Stewart Headlam the idea of a religion hostile to human nature. At the age of thirteen, he went to Eton where he came under the care of William Johnson, a personal friend of F. D. Maurice. Johnson introduced him to Maurician theology and a more positive and lenient religion than he had been exposed to at home. In 1865, Headlam went up to Cambridge to study under F. D. Maurice himself. Maurice's interpretation of Scripture, his notions of a benevolent God, the Humanity of Christ, of a Kingdom of Heaven to be established upon earth, and his pioneering social initiatives deeply impressed the young Headlam and remained a lifelong influence.

After graduating in 1868, Headlam became curate of St. John's, Drury Lane, a parish in central London in the immediate vicinity of theatres and music halls. Here, he developed his enthusiasm for the ballet, the "art of motion", and a strong compassion for the dancing girls and actors who were shunned by respectable society and forced to live on its fringes ${ }^{173}$. In 1879 , Headlam shocked the Anglican establishment by founding the Church and Stage Guild, a body designed to facilitate relations between the two, to celebrate the beauty and godliness of the performing arts and to rehabilitate the theatre folks as workers in the name of $\operatorname{God}^{174}$.

Headlam's sensitivity to human suffering and his acute sense of justice were sorely tried when in

\footnotetext{
173 Jones, Peter d'Alroy, The Christian socialist revival 1877 - 1914. Religion, class, and social conscience in lateVictorian England, 1968, p.101; Leech, Kenneth, Stewart Headlam 1847-1924 and the Guild of St. Matthew, 1968, p.68

174 Orens, John, Stewart Headlam's radical Anglicanism, 2003, p.16-33; see also Norman, Edward, The Victorian Christian socialists, 1987, p.109f
} 
1873, over a controversy with his rector, he was asked to leave Drury Lane and transferred to St. Matthew's in Bethnal Green, one of the poorest districts of London ${ }^{175}$. The young curate found himself appalled and enraged by the squalor and destitution in which his parishioners lived. He considered it outrageous that members of the Church of England, the great Body of Christ, should have to exist under such inhumane and crushing conditions ${ }^{176}$. His encounters with slum ritualism at the neighbouring church of St. Michael's, Shoreditch, left a powerful impression on Headlam's mind during that period. Against the background of the poverty and hideousness which he witnessed daily on the streets of Bethnal Green, the experience of the beauty and dignity of Anglo-Catholic ritual and the powerful message of communal worship and in particular of the Eucharist, the great sacrament of community, appeared to Headlam like a saving grace ${ }^{177}$.

His encounters with the aesthetics of ritualism on the one hand and the ugliness of his parishioners' lives on the other formed the backdrop to the founding of his Guild of St. Matthew in 1877. The organisation constituted Headlam's main vehicle for the promotion of his newly-forming social theology. From the beginning, the Guild pursued dual aims. Designed as a parish organisation to encourage attendance at the early morning service and at Holy Communion, its intentions were religious and sacramental. At the same time, it included as one of three objects in its programme the study of social and political questions "in the light of the Incarnation", and was a political body. At its inception in 1877, the Guild of St. Matthew listed 40 members, all local. With Headlam's dismissal from Bethnal Green in 1878 over a quarrel with the bishop, it grew into a national organisation, but never had more than about 370 members, the high point being around $1895^{178}$. Unlike the larger and more widespread Christian Social Union of Henry Scott Holland and Charles Gore, it never managed to appeal to a wider audience and remained a predominantly clerical body. At the time of its greatest membership, more than a fourth of its adherents, 99 out of 367, were clergy. But as the first socialist society in England, founded just before Hyndman's Social Democratic Federation and several years before other Christian Socialist groups, it performed a pioneering task and prepared the way for larger, more comprehensive and possibly more successful organisations which were to follow.

Not surprisingly, Stewart Headlam never had much of a clerical career. After his stints at Drury Lane and Bethnal Green, he worked as curate or assistant, among other places, at St. Michael's, Shoreditch, at St. Thomas', Charterhouse, at St. George's, Botolph, and at St. Mary's in Soho. At a time when evangelical thought still constituted a major force in the Church of England, Headlam's

\footnotetext{
175 Orens, John, Stewart Headlam's radical Anglicanism, 2003, p.18

176 Orens, John, Stewart Headlam's radical Anglicanism, 2003, p.19ff

177 Leech, Kenneth, Stewart Headlam 1847-1924 and the Guild of St. Matthew, 1968, p.64

${ }^{178}$ Leech, Kenneth, Stewart Headlam 1847-1924 and the Guild of St. Matthew, 1968, p.68
} 
Maurician views stood in the way of his being licensed and promoted. His championship for the stage and the ballet, his open support for Oscar Wilde and his Anglo-Catholic ritualist tendencies, not to mention his socialist leanings, put him outside the bounds of acceptable opinion within the Church of England. However, most significant in hindering his career may have been his open criticism of the Church of England and her teachings. Headlam accused the Anglican Church of driving away her own members by insisting on unreasonable and irrelevant doctrines such as the infallibility of the Bible. Headlam considered it an offence against the intellect and a crime against humanity to teach people that God created the world during the first six days of the year 6006 B.C. "[T]here are still young men allowed to go out into the world so poorly equipped, so far as religion is concerned, that they are ready to lose their faith in Christ and His Church because they get convinced that the story of the Fall is not literal history"179, he criticized.

Headlam insisted that the Church could not hope to re-gain the masses before she put Jesus Christ the Man, his life and teachings, in the place of Scripture as the basis of her dogma ${ }^{180}$. Life in this world rather than the next, he demanded, had to become the focus and centre of attention of the Church. Christianity, for Headlam, was inherently political. Whosoever continued the representative specimen work began by Christ in Palestine, was in Headlam's eyes a true follower of the Carpenter and a child of God. He enraged his superiors and the Anglican establishment through his open support of the highly controversial secularist MP and social activist Charles Bradlaugh ${ }^{181}$ and the entire secularist movement whom he praised as secular workers in the spirit, although obviously not in the name, of Christ. In an obituary for Bradlaugh in 1891, Headlam explained that "[h]owever much Mr. Bradlaugh might say that he did not know God, as he had taken infinite pains to bring about the time when the people of England should be properly fed and housed, God knew him and claimed him His" ${ }^{182}$. Although he disapproved of their atheism, Headlam cooperated closely with the secularist movement, delivering lectures at Secular Society meetings and giving and attending courses in the Old Street Hall of Science, Bradlaugh's headquarters.

Since his early curacy at St. John's, Drury Lane, Headlam had been interested in social questions. But against the poverty which he encountered most forcefully in the backstreets of Bethnal Green, he could at first only place a vague social theology based on the principles of community, cooperation and universal brotherhood. The publication in England of Henry George's Progress and

\footnotetext{
179 Headlam, Stewart Duckworth, The Socialist's Church, 1907, p.30

${ }^{180}$ Headlam, Stewart Duckworth, The Socialist's Church, 1907, p.33

${ }^{181}$ Charles Bradlaugh (1833 - 1891) was a political activist and secularist. In 1866, Bradlaugh co-founded the National Secular Society. He acted as editor of the National Reformer which was prosecuted repeatedly for blasphemy and sedition. In 1880, Bradlaugh was elected MP for Northampton, but was prevented from taking his seat when he was denied the right to affirm. In the following, he became famous for his campaigns for the rights of secularists and atheists. In 1886, Bradlaugh was finally allowed to take the oath and take up his seat in Parliament.

182 As quoted in Orens, John, Stewart Headlam's radical Anglicanism, 2003, p.24
} 
Poverty in $1881^{183}$ marked a personal turning point for him. He found himself convinced by George's exposition of the problem of landlordism as the root evil of modern society. He also appreciated the deep religiosity of the book's author. George to Headlam appeared like a soul mate in his struggle for a social and religious revival ${ }^{184}$. He became a life-long devotee to the cause of George's Single Tax on land values. Headlam acknowledged the enormous influence of the American on his own work and British progressivism in his treatise The Socialist's Church: "The stimulus he gave to Socialism cannot be overestimated"185, he wrote. Headlam was a founder member of the English Land Restoration League (originally the Land Reform Union, to be renamed English League for the Taxation of Land Values in 1902). Land Reform also became one of the main planks in the political programme of the Guild of St. Matthew, and Headlam devoted considerable space to the subject in his paper The Church Reformer ${ }^{186}$.

Headlam was, in his political and economic opinions as much as in his ecclesiastical and doctrinal views, an independent thinker. He was never content to stick to a single course or a particular political group or party. He considered any organisation working for social progress to be worthy of support and a vehicle for furthering his own agenda. Beside his devotion to the Georgeist cause, he was also an active member of the Fabian Society which he joined in 1886 . He was part of the Committee of Fifteen which drew up the Fabian Basis, served on their executive in 1890/1 and again from 1901 to 1911, and was the author of two Fabian Tracts on Christian Socialism ${ }^{187}$. He felt at home in the Liberal Party, but at the same time expressed an interest in Hyndman's Social Democratic Federation in the early years of the organisation although he never appeared to have joined it.

Stewart Headlam died in 1924 of a heart attack in his home.

${ }_{183}$ George, Henry, Progress and poverty, 1881

184 Orens, John, Stewart Headlam's radical Anglicanism, 2003, p.50ff

${ }^{185}$ Headlam, Stewart Duckworth, The Socialist's Church, 1907, p.60

186 Jones, Peter d'Alroy, The Christian socialist revival 1877 - 1914. Religion, class, and social conscience in lateVictorian England, 1968, p.127. George Bernard Shaw and Sidney Webb both described the Church Reformer as a Socialist organ of considerable influence and standing.

187 Headlam, Stewart Duckworth, Socialism and Religion, 1907, republished in Socialism and Religion by the Rev. Stewart Duckworth Headlam, the Rev. Percy Dearmer, the Rev. John Clifford, \& John Woolman. Fabian Socialist Series No 1, 1908; and Headlam, Stewart Duckworth, Christian Socialism: a lecture, Fabian Tract No. 42,1892 


\section{Stewart Headlam's Social Theology}

In Stewart Headlam's social thought, his reformist endeavours and his religious beliefs were intricately interwoven. Among the reformers to be examined in this study, he was the thinker who constructed the most elaborate theological basis for his social programme. In order to explain and justify his reform proposals, he drew on arguments derived from his theological convictions, from an innovative reading of the Bible and from untraditional interpretations of established Christian doctrine.

Contrary to the strong evangelical current within the Church of England, for Headlam, religion was an essentially this-worldly affair. At the centre of his religious beliefs stood the doctrine of the Incarnation. His theology focused not on Scripture or the writings of the Church Fathers as did the theology of evangelicalism, but on Jesus Christ the Man and on his life upon earth. From Maurice, Headlam had taken over the idea of the "perfect Humanity of our God Jesus Christ"188. In Christ, Headlam held, God had become Man, a real human being in flesh and blood. He had lived a basically normal human life with all its accompanying joys and challenges, experiences good and bad, and by doing so, God had given a triple message. First, Headlam held, God had sanctified human life. He had broken down the barriers between religious and secular, this-worldly and otherworldly. By assuming the human form and living among men, Headlam believed, God had emphatically asserted the dignity of all aspects of human society and the human body.

The core belief of Headlam's theological system was the idea that by becoming man, Jesus had bestowed dignity and sacredness upon the individual. Against the sin-ridden image of mankind held by puritans, Headlam placed a positive, perfectible vision of humanity. He believed that every single man and woman was an image of Christ and as such deserved the same respect and love as offered to the Son of God. The Incarnation had sanctified the individual and individuality. The inner faculties of men and women, their emotions, their sensual experiences, their intellectual capacity, all formed part of God's creation. As divine gifts, Headlam argued, they deserved to be developed and celebrated. He considered it Christian duty to offer all men and women the opportunity to do so.

Headlam turned against the evangelical tendency to withdraw from the world. "The value of this life and all its manifold relationships, the sacredness of humanity could by no possibility be more strongly asserted than it is by the life and teaching of Jesus Christ" ${ }^{189}$, he held. Evangelicals thought

188 Headlam, Stewart Duckworth, The Service of Humanity, and other sermons, 1882, p.1

189 Headlam, Stewart Duckworth, Lessons from the Cross. Addresses given in Oxhey Parish Church on Good Friday, 1886,1887, p. 24 
to do honour to Jesus by drawing clear lines between things secular and things religious and believed that the Church should confine herself to religious ministrations while the bodily and material welfare of the community should be left to others ${ }^{190}$. Headlam asserted the opposite view. As the living "body of Christ the Man", the Church had a particular duty towards all things human, he argued. Jesus had entrusted it with the care of souls as well as bodies, the care for all aspects of human existence which furthered and celebrated the individual and individuality. During a lecture at the secularist South Place Chapel he went as far as to all the Church of England "in theory the greatest secular society in the country" ${ }^{\prime 191}$. Headlam took it upon himself to turn the church into an agent of secular political life.

The second message of the Incarnation was one of universal brotherhood. Headlam reasoned that if Jesus Christ, "Representative Man"192, was the Son of God, so were all men. The Fatherhood of God implied for him a corresponding brotherhood of all human beings. By directing attention to the atonement and human sinfulness, evangelicalism had helped to establish within the Church of England an individualistic piety aiming at personal salvation and a disregard for the fate of one's fellow humans. Headlam believed that Jesus in his life and teachings had shown such egocentric pietism to be not only misguided, but positively wrong and harmful. In Headlam's interpretation, Jesus had wanted men to lead a life of brotherhood, cooperation, solidarity and mutual care and to recognise their mutual dependence as brothers. He had taught his disciples to live in harmony, and to take care one of the other in mutual love and respect as did members of a family.

The third fundamental truth Headlam derived from the doctrine of the Incarnation was political. Jesus, by sanctifying the material world and teaching men to live as brothers, had come to fulfil God's plan for his creation. With his life and works, Headlam preached, Christ had made it abundantly clear that the scriptural Kingdom of God did not constitute a place in the clouds to be inhabited by the elect few, but a "righteous condition of things to be established upon earth" 193 . Headlam envisaged a "society of people loyally bound to one another in charity" 194 in which men lived and worshipped as brothers; he believed in a "Communistic Society" that could and should be established in modern industrial England "in which all were to be fed as surely as the birds and clothed as beautifully as the lilies"195. Eternal life, which Christians for centuries had taken to mean life after death, referred in Headlam's theological system to quality rather than duration; it signified life in the Kingdom of God upon earth, the fair, equitable and brotherly society Jesus had come to

\footnotetext{
190 Headlam, Stewart Duckworth, The Service of Humanity, and other sermons, 1882, p.4

191 Headlam, Stewart Duckworth, The Secular Work of Jesus Christ, his apostles and the Church of England, 1886, p.20

${ }^{192}$ Headlam, Stewart Duckworth, The Secular Work of Jesus Christ, his apostles and the Church of England, 1886 , p.10

193 Headlam, Stewart Duckworth, The Socialist's Church, 1907, p.39

${ }_{194}$ Headlam, Stewart Duckworth, The Service of Humanity, and other sermons, 1882, p.71

195 Headlam, Stewart Duckworth, The Service of Humanity, and other sermons, 1882, p.11
} 
found $^{196}$.

Headlam pointed to reports on the lives of early Christians who had shared their possessions and their homes regardless of social status in a quasi-communistic set-up. The very first followers of Christ, he stressed, had put into action his lessons and come up with a small-scale version of what Scripture meant by the Kingdom of Heaven. Headlam conceded that in the process of God's ordering of the world, things had become complicated and this simple communism was no longer practicable. The principle which lay behind it, however, held true throughout the centuries and the various stages of an evolving human society ${ }^{197}$. Two signposts pointed the way towards the fulfilment of God's grand design for mankind. With his Church, Christ had founded the kernel of the society to come and left men with a blue print of the Kingdom of Heaven. Secondly, with his exemplary life, Jesus had directed men to be participating members of the human community, or in more pointed words, active citizens of their states.

Headlam's entire theology grounded in the belief that Jesus was a political man, "the Saviour, the social and political emancipator, the greatest of all secular workers" ${ }^{198}$. Hence he concluded that the best service to God was not private prayer or fasting, but any service rendered to fellow men or the community at large. In a sermon on Maunday Thursday, published in 1882, Headlam related the story of Jesus washing his disciples' feet. The act, he argued, revealed in Christ the servant of humanity: "The work of Jesus Christ and His Church is then, in this Maunday Thursday event, (...) shewn to be secular work: all work for Humanity, material as well as spiritual, is today revealed as being 'of Christ"'199. All who administered to the wants of humankind - the labourer who provided food, clothes, shelter or transport for his fellow-men as much as the politician whose care was the smooth running of communal life - were in Headlam's eyes true disciples of Jesus Christ, regardless of their religious adherence. Headlam included in this all-embracing statement not only Charles Bradlaugh and the Secularists, but also the Marxist, anti-ecclesiastical and anti-religious SDF ${ }^{200}$. Headlam substantiated his unorthodox interpretation of the Christian faith with quotes from the Bible. Scripture, he held, was full of instructions for the followers of Christ on secular work, social issues and political questions. The parables, for instance, carried a clear political message of justice, brotherhood and mutual care. With them Christ had proclaimed that social service and mutual help counted more in the eyes of God than did outward worship and formal religion. If God himself said

${ }^{196}$ Headlam, Stewart Duckworth, The Meaning of the Mass. Five lectures, with other sermons and addresses, 1905, p73

${ }^{197}$ Headlam, Stewart Duckworth, The Meaning of the Mass. Five lectures, with other sermons and addresses, 1905, p.29

198 Headlam, Stewart Duckworth, The Sure Foundation. An address given before the Guild of S. Matthew, at the annual meeting, 1883, 1883, p.6

199 Headlam, Stewart Duckworth, The Service of Humanity, and other sermons, 1882, p.3

200 Jones, Peter d'Alroy, The Christian socialist revival 1877 - 1914. Religion, class, and social conscience in lateVictorian England, 1968, p.103 
that goodness consisted in seeing that the people were equipped with life's essentials, Headlam emphasized, "then surely it is the bounden duty of every minister of Christ, from the Archbishop of Canterbury down to the humblest Sunday School teacher, to be doing their best to see that the men, women and children of England are properly clothed, fed and housed." ${ }^{201}$ In Headlam's way of reading it, the Bible documented the sacredness of secular communal life ${ }^{202}$. Human government, the agent of secular welfare, was a divine institution as well as the Church, he asserted. Christ had clearly told his followers to honour the king and to give unto Caesar what was Caesar's. Headlam derived from this remark the duty of all Christians to be active citizens to the advantage and welfare of the whole community ${ }^{203}$.

Headlam also considered the miracles to be markers on the path to be travelled by the good Christian. They commanded the followers of Christ to help deliver people from an evil environment or fatal heredity. Headlam took Jesus' works of healing as indicators that dirt, pauperism, low wages and long hours of wearisome work, ignorance and drunkenness, everything that hindered health and fostered disease, must by true Christians be fought against. Premature death, too, formed no part of God's order of the world, Headlam believed. Though the death of an old man passing in his sleep, Headlam agreed, was a natural, orderly and almost beautiful thing, Christ had clearly demonstrated in his miracles that the deaths of a child or a young man in the prime of life constituted a monstrous violation against divine intentions and were the result of wrong-doing somewhere or other.

At Kana'an or at the gathering of thousands at the lake Genezareth, the Bible reported on how Christ had used what powers he had to help feed the masses and see to it that all had enough of the necessary and the good things in life. Headlam interpreted the passages as a declaration of war on famine. It was against God's order, Headlam argued, that underfed babies should be born of malnourished mothers and should grow up weak in mind and body. For Headlam, that the few should enjoy good food and excellent wine and leave the many to starve directly followed from a system of unrestrained competition and an atmosphere of unenlightened selfishness which ran counter to Christ's message of justice and brotherhood ${ }^{204}$. Disease, premature death and famine all constituted man-made interferences with God's plan for mankind, Headlam inferred, and could and must therefore be gotten rid of by men who considered themselves followers of Christ.

Headlam defended himself against allegations that through his unorthodox interpretation of Scripture, he violated the customary political neutrality of the Church. It was true, Headlam conceded, that he brought politics into the pulpit, but doing so was part of his self-image, and his

\footnotetext{
${ }^{201}$ Headlam, Stewart Duckworth, Christian Socialism: a lecture, etc, 1892, p.9

${ }^{202}$ Headlam, Stewart Duckworth, The Meaning of the Mass. Five lectures, with other sermons and addresses, 1905 , p.17

203 Headlam, Stewart Duckworth, The Service of Humanity, and other sermons, 1882, 76ff

${ }^{204}$ Headlam, Stewart Duckworth, The Secular Work of Jesus Christ, his apostles and the Church of England, 1886, p.5
} 
mission, as minister of God. "[I]f we are to do all to the glory of God, if the Kingdoms of this world are, as Christ declared, God's and not the Devil's, if the Church has to deal with the whole and not merely a section of human life, then those matters must be dealt with in the pulpit" 205 , he argued. The life and works of Jesus Christ, Scripture reporting on his miracles and his parables, Christian doctrine and Christian ritual in Headlam's interpretation all made it clear that God had a plan for secular human society, and that he intended to established his Kingdom in this world, not the next. All those who believed in Jesus Christ and his Church were bound to work for definite social reforms ${ }^{206}$.

Headlam called on churchmen and -women to make an effort to note not only the state of their own souls, but also the state of the nation of which they were part and towards which they had duties to discharge ${ }^{207}$. Every single individual played a part in the nation's welfare and Headlam considered it a Christian duty to take the responsibility seriously. It was easy, he noted, to denounce the shopkeeper, the middleman, the employer for the evil conditions under which a large part of the nation lived ${ }^{208}$. But consumers shared the blame. The bread they bought and clothes they wore were often produced under inhuman conditions. "[T]race back the history of them", Headlam suggested, "and none of you can say that you are not guilty of theft and of murder, that no one who has been concerned in the various processes which have led to their manufacture has not been defrauded of his due wages, or shortened in his life."209

He reminded his audience that as consumers, every member of the nation was also an employer of labour and had duties towards his "hands". Headlam pointed out that in the case of his housemaid, no self-respecting middle-class householder would deny his responsibility. Headlam hoped to make men understand that in commercial transactions outside the home, too, they employed thousands of servants to whom they owed fair wages, sanitary homes and educational opportunities ${ }^{210}$. Every member of the community was in Headlam's eyes "his brother's keeper"; the political duties of the Churchman had a very personal aspect to them. "On you [as Churchmen] rests the obligation to treat all mankind as redeemed", he demanded, "to treat the whole human family as having a Common Father." ${ }^{211}$ His experience as curate in some of the poorest districts of London never let him forget the human level of the social question.

\footnotetext{
${ }^{205}$ Headlam, Stewart Duckworth, The Secular Work of Jesus Christ, his apostles and the Church of England, 1886, p.13

${ }^{206}$ Headlam, Stewart Duckworth, The Secular Work of Jesus Christ, his apostles and the Church of England, 1886 , p.16

207 Headlam, Stewart Duckworth, Lessons from the Cross. Addresses given in Oxhey Parish Church on Good Friday, 1886,1887 , p.7

208 Headlam, Stewart Duckworth, The Church and Socialism, 1890, p.229

209 Headlam, Stewart Duckworth, Lessons from the Cross. Addresses given in Oxhey Parish Church on Good Friday, 1886,1887, p. 13

210 Headlam, Stewart Duckworth, Christian Socialism: a lecture, etc, 1892, p.18

211 Headlam, Stewart Duckworth, The Meaning of the Mass. Five lectures, with other sermons and addresses, 1905 , p. 125
} 


\section{Headlam's Political Agenda}

a) Towards Equality and Brotherhood: The Socialist Message of the Sacraments

The belief in the sacredness of humanity and the dignity of the individual as derived from his faith in the Incarnation also formed the basis of Headlam's social agenda. While there existed in England thousands of men, women and children whose wants were not sufficiently provided for and who were impeded in their personal growth, he considered it a Christian duty to fight on their behalf for a reform of society ${ }^{212}$. Headlam quoted the diagram published by Leo George Chiozza Money in his book Riches and Poverty ${ }^{213}$ to show that at present, eighty percent of the population in Great Britain lived in poverty, curtailed in mental and bodily development through a lack of opportunity and of material resources.

Headlam traced the imbalance of wealth and opportunity back to the system of unlimited competition and the principle of laissez-faire which at the time underlay the English economy. He criticised that modern English society had lived on the principle of "every man for himself and the devil take the hindermost". "We have lived as rivals and competitors instead of living as brothers", Headlam wrote, "labourer competing against labourer, artisan against artisan, shopkeeper against shopkeeper (...) with the result that very few of us are clothed beautifully and many of us not fed surely." ${ }^{214}$ Headlam argued fervently that contrary to the teachings of classical political economists, unlimited competition did not give to all equal opportunity to gain beautiful clothes and good food; it did not even provide the majority with life's essentials ${ }^{215}$.

Headlam called on all members of society to turn against the established modes of dealing with poverty and to rally their forces in order to tackle the problem at its economic and social roots. He accused his contemporaries of having forgotten the traditional Christian values of human dignity and social justice. He quoted the Archbishop of Canterbury who at the Lambeth Conference of 1888 had proclaimed that the factory hand had no right to be content with his meagre pay ${ }^{216}$. Nor should the better-off feel satisfied with and exculpated through occasional donations to individuals or charitable institutions. Headlam turned violently against the century-old tradition of alms-giving which in his opinion only served to cement the present inequalities and to stabilise an inherently

\footnotetext{
${ }^{212}$ Headlam, Stewart Duckworth, Lessons from the Cross. Addresses given in Oxhey Parish Church on Good Friday, 1886, 1887, p.34f

213 Chiozza Money, Leo George, Riches and Poverty, 1905; as quoted in Headlam, Stewart Duckworth, The Socialist's Church, 1907, p.15

214 Headlam, Stewart Duckworth, Christian Socialism: a lecture, etc, 1892, p.7

215 Headlam, Stewart Duckworth, The Secular Work of Jesus Christ, his apostles and the Church of England, 1886 , p.9

${ }^{216}$ Headlam, Stewart Duckworth, The Guild of St. Matthew, an appeal to Churchmen. Being a sermon etc, 1890 , p.9
} 
unjust social system. "Though we can never have enough sympathy", he maintained, "we have had enough sentimental talk and enough spasmodic action founded merely upon sentiment, touching the evils only on the surface, not going to the root of them." ${ }^{217}$ These evils, he pointed out, could never be alleviated by maudlin charity, but had to be prevented by Christian justice. Headlam criticised that charity of the traditional kind tended to degrade the receiving individual and thus to aggravate the problem. He called for a solution which respected the sacredness of the human being and restored the individual to dignity.

In Headlam's eyes, the sordid conditions of modern industrialised society marred the spiritual and moral welfare of all members of society. It inhibited the rich as much as it did the poor in their personal development. He argued that while the latter found themselves compelled to work excessive hours for a mere pittance with no time or resources for the higher things in life, the former were cheated out of one of the basic pleasures of human existence - the pleasure of earning one's living by the labour of one's own hands or brain. Headlam considered it a Christian's duty to God as well as to "our neighbour" 218 , to get those conditions altered. "When the Social Revolution has come", he hoped, "the common humanity which, though crushed and covered by our present anarchic conditions, is to be found quite as much among those who are now the rich as among the poor, will be able to assert itself." 219

Headlam postulated that Britain discard the individualism of Benthamite utilitarian teachings and instead reclaim as basic social values the two principles which he considered to be the kernel of Christ's political message and which he found expressed in traditional Christian ritual: the ideas of total equality and of universal brotherhood among men. The principle of brotherhood he found commemorated and affirmed with every Eucharist celebrated within a church or chapel. Already through its name, the sacrament of Holy Communion carried the message of communal life. Headlam argued that it pledged men to a life of solidarity and interdependence ${ }^{220}$. In it, all alike became sharers of bread and wine, signifying both material necessities as well as spiritual wealth.

Christ, Headlam believed, had given a clear indication that salvation, whether spiritual or secular, could never be attained individually, but only communally by living as active members of a brotherly society. Holy Communion as a constant reminder of the Incarnation spurred on Christians to follow Christ's example in spiritual as well as social and political life. "Can you face Jesus Christ

\footnotetext{
${ }^{217}$ Headlam, Stewart Duckworth, The Guild of St. Matthew, an appeal to Churchmen. Being a sermon etc, 1890, p.9

${ }^{218}$ Headlam, Stewart Duckworth, The Guild of St. Matthew, an appeal to Churchmen. Being a sermon etc, 1890, p.9; see also Headlam, Stewart Duckworth, The Secular Work of Jesus Christ, his apostles and the Church of England, 1886

219 Headlam, Stewart Duckworth, The Secular Work of Jesus Christ, his apostles and the Church of England, 1886 p.18

${ }^{220}$ Headlam, Stewart Duckworth, The Laws of Eternal Life, etc, 1897, p.97; see also Headlam, Stewart Duckworth, The Secular Work of Jesus Christ, his apostles and the Church of England, 1886, p.16
} 
Sunday by Sunday", Headlam asked in his sermons, " and not be doing your best - more than you have done - to help to make the world more like what He, by His representative specimen work in Palestine, showed that He intended it to be?"221 The Eucharist bound all those who partook in it to help forward the coming of his Kingdom upon earth.

Equality, Headlam believed, was celebrated and manifested in the sacrament of Baptism. He held that through the act of christening, the Christian community claimed every baby born into this world as being the equal with every other baby in a manner more radical than the French Revolution had ever done. Headlam emphasised that the Church did not differentiate between the child of a costermonger or the child of a prince ${ }^{222}$. In the act of baptising, neither considerations of social class or material wealth, nor of gender, nor of political affiliations played a part. Baptism demanded nothing of the child, whether in wealth or deed. "[N]ot waiting for conversion or illumination or election or proof of goodness, but simply because it is a human being, we claim it as of right a member of Christ, the child of God and an inheritor - not merely a future heir, but a present inheritor - of the Kingdom of Heaven" ${ }^{\text {223 }}$, he wrote.

The messages carried by the sacraments of equality and brotherhood formed the backdrop of Headlam's arguments on social questions. For him, the principles of the Christian community translated directly into political rights and maxims for living together in secular society 224 .

b) Socialism as the Political Ideology of Christ the Man

In the political landscape of late Victorian England, Headlam thought these principles best embodied in the political ideas of socialism. For his particular brand of his political faith, he borrowed the phrase Christian Socialism (spelling it with a capital "S") from F. D. Maurice and his friends. Headlam was well aware that some objected to the concept of a Christian Socialism on principle. For many, the two terms sounded contradictory and mutually exclusive, but he relished in the friction they created in many believers' ears. Headlam intended to shock, and he meant to shake Christians into "aggressive militant action" 225 . In his eyes, men had been "too contented"226 with the present shape of society: the leisured classes had shut their eyes to the secular side of Christ's

\footnotetext{
221 Headlam, Stewart Duckworth, The Secular Work of Jesus Christ, his apostles and the Church of England,1886, p.17

222 Headlam, Stewart Duckworth, The Meaning of the Mass. Five lectures, with other sermons and addresses, 1905, p.28; see also Headlam, Stewart Duckworth, The Socialist's Church, 1907, p.71

223 Headlam, Stewart Duckworth, Christian Socialism: a lecture, 1892, p.13

${ }^{224}$ Headlam, Stewart Duckworth, The Secular Work of Jesus Christ, his apostles and the Church of England, 1886, p.15

225 Headlam, Stewart Duckworth, The Secular Work of Jesus Christ, his apostles and the Church of England, 1886, p.16

${ }^{226}$ Headlam, Stewart Duckworth, The Secular Work of Jesus Christ, his apostles and the Church of England, 1886, p.5
} 
work $^{227}$, while the poor submitted too easily to their lot and consented to work for wages criminally inappropriate to the services rendered. Headlam alienated respectable society by speaking, in Marxist parlance, of the need for a "social Revolution", although he meant it to be a revolution not of bloodshed and violence, but of "reconciliation, (...) peaceful, orderly and legal (...) by means of which, when robbery is prevented, the wolf and the lamb, those who are now the sweater and the sweated, the rich and the poor, shall feed together" ${ }^{\prime 228}$.

"When people have asked me what is the difference between Christian Socialism and other Socialism", Headlam explained in the Church Reformer, "I have been in the habit of saying that economically, there is no difference: that the motive power often is different and that we appeal to different people and on different grounds, but that the economic basis is the same." ${ }^{229}$ In his eyes, free education, school meals, shorter working days, minimum wages and the reform of taxation all constituted reforms which any loyal member of the Christian Church ought to work for. In the two fundamental positions which underlay socialist teaching, he detected reformulations of the essential Christian principles of equality and brotherhood. As the first principle, Headlam listed the notion that every man should work. The socialist concept of society provided for no idle class which consumed without producing, no privileged body allowed to live upon the labour of others. "What is this but Christian teaching?" Headlam asked. "St. Paul's labour law, if strictly applied to modern society, would effect a social revolution: 'If any will not work, neither let him eat'." ${ }^{230}$ He criticised the fact that in late-Victorian England, a man was often honoured and enriched in inverse proportion to the amount of useful work he did. Both, the "Christian inheritor of broad acres" as well as the labourer on his estate, were bound by the biblical command to work on six days per week, Headlam held.

The second socialist principle as Headlam saw it called for a more equitable distribution of the produce of labour. This idea, too, chimed in with biblical teaching. "The husbandman that laboureth must be the first to partake of the fruits", Headlam quoted from the letters of St. Paul ${ }^{231}$. The object of Christian Socialism, Headlam offered, was to bring about a time when all should work and robbery in the form of the inequitable distribution of produce be abolished ${ }^{232}$. He cited calculations from an unknown source which had shown that if all took their fair share in the labour necessary to supply for the material needs of the nation, none would have to work for more than four or five

\footnotetext{
227 Headlam, Stewart Duckworth, The Service of Humanity, and other sermons, 1882, p.3

${ }_{228}$ Headlam, Stewart Duckworth, The Secular Work of Jesus Christ, his apostles and the Church of England, 1886, p.18

229 Headlam, Stewart Duckworth, The Church and Socialism, 1890, p.220

${ }^{230}$ Headlam, Stewart Duckworth, The Lambeth Conference and Socialism, 1888, p.181

231 Headlam, Stewart Duckworth, The Lambeth Conference and Socialism, 1888, p.181; see also Headlam, Stewart Duckworth, Christian Socialism: a lecture, 1892, p.13

${ }^{232}$ Headlam, Stewart Duckworth, Christian Socialism: a lecture, 1892, p.12
} 
hours a day ${ }^{233}$. Then, Headlam envisioned, work would finally be a joy and fulfilment instead of the grind it was at present to those who had to provide not only for their own living, but for the wants and luxuries of those who considered themselves their social betters. Of course, he conceded, Christ had not himself been an economic socialist. But he had laid down the principles of brotherhood which in Victorian England required economic socialism for their accomplishment. "The banner of Christ is now in the hands of the Socialists" ${ }^{234}$, Headlam concluded.

Headlam took pains to stress that for him, secular socialism constituted an economic doctrine, not a philosophy of life. He appreciated his fellow churchmen's worries that socialism take on the form of a religion, dealing with ethical as well as economic questions and opposing Christian teaching on so important a matter as for instance the questions of marriage and the family. Socialism as Headlam understood it had but one end in view, the establishment of righteous industrial and material conditions $^{235}$. For Headlam, questions on the family, sex, and eugenics, important as they were, took second place behind the paramount issue of the industrial revolution and should only be addressed once equitable and righteous material conditions had been established. Wage slavery had to be abolished before the finer points of social organisation could even be properly thought about. Headlam abhorred the fact that policies of the above kind tended to give the impression that socialism aimed at curtailing personal liberty. As a professing Christian Socialist, he assured his readers, he did not dream of reconstituting society in any way in which individuality should be suppressed. In Headlam's eyes, it was on the contrary the present system of unlimited competition and so-called liberalism which undermined social progress by preventing the individual from living a free and full life and destroying social institutions like the family. "We are Socialists because we believe that the abolition of the monopoly in the main means of production will make these organisms much stronger than they are now, not because we think it will get rid of them" ${ }^{236}$, he explained.

\section{c) A Classless Society of Brothers}

As the logical consequence of Christ's teachings on human dignity, equality and community, Headlam envisaged a society in which all class distinction, whether based on material possessions or social status, would shrivel into nothingness. In the Kingdom of God, he believed, the

\footnotetext{
${ }^{233}$ Headlam, Stewart Duckworth, The Socialist's Church, 1907, p.67

${ }^{234}$ Headlam, Stewart Duckworth, The Socialist's Church, 1907, p.40

235 Headlam, Stewart Duckworth, The Socialist's Church, 1907, p.49

236 Headlam, Stewart Duckworth, The Church and Socialism, 1890, p.221
} 
sacramental principle of absolute equality would lead to a re-classification of society. The present social system which the poet and cultural critic Matthew Arnold ${ }^{237}$ had in Headlam's opinion aptly described as a "materialised upper class, a vulgarised middle class and a brutalised working class" would give way to John Ruskin's model of "Beggars, Robbers and Workers" 238 . The category of workers, Headlam specified, comprised the bulk of the population and included all who did not live on the labour or the charity of others, but gave back to society some produce of hand or brain equal to the amount consumed, be it as a manual labourer, as a professional or a captain of industry. Under the headings beggars and robbers he brandished those who would continue to refuse to contribute their share to the common good. Headlam hoped for a society in which the members of all classes moved closer together to form a common body of loyal and interdependent citizens. ${ }^{239}$ Headlam turned forcefully against arguments that Scripture sanctioned the present division of society into rich and poor, educated and ignorant. He interpreted Christ's had blessing of the poor as a praise of their moral strength and personal integrity as opposed to the hypocrisy of the rich and learned Pharisees and Scribes; his remark was, Headlam stated emphatically, not a sanctioning of their social status or material situation ${ }^{240}$. Jesus' frequently cited phrase "The poor ye shall always have with you", he pointed out, was in fact a misquotation. The original read "The poor ye have always with you". The former phrase contradicted the whole of Christ's life and work which in Headlam's eyes was clearly directed at getting rid of misery and destitution. "If He had said that when His Kingdom was established - one object of which was to get rid of poverty - there should still be poverty He would have stultified Himself"241, Headlam argued.

God had endowed men with a fruitful earth and with intelligence to make use of it to the common good. In terms of the gross national income, England's wealth had risen phenomenally since the early days of the Industrial Revolution. Headlam considered it a monstrosity that side by side with all this progress in the power and intelligence of man to make much of the resources at hand, there existed such abject poverty. He was adamant that Christ's utterances as quoted above should not be read as a directive as to the proper ordering of society, but an ascertainment of a lamentable fact about human nature. Even under the best possible social and economic system, Headlam agreed, a man who was a loafer and refused to work when he had every opportunity to do so would fall into poverty. But he refused to believe that it was God's will that those who laboured in order to produce

\footnotetext{
237 Matthew Arnold (1822-1888), son of Thomas Arnold, the educationalist and headmaster of Rugby School. Matthew Arnold is remembered particularly for his poetry which is ranked alongside that of Robert Browning and Alfred Tennyson, and which often contained harsh criticism of the prevalent social conditions in Victorian Britain.

238 Headlam, Stewart Duckworth, Christian Socialism: a lecture, 1892, p.8

239 The idea of a universal duty to work will re-appear in this thesis in the chapter on Leo George Chiozza Money.

${ }^{240}$ Headlam, Stewart Duckworth, The Guild of St. Matthew, an appeal to Churchmen. Being a sermon etc, 1890, p.10ff; see also Headlam, Stewart Duckworth, The Socialist's Church, 1907, p.41

${ }^{241}$ Headlam, Stewart Duckworth, Christian Socialism: a lecture, 1892, p.11
} 
real wealth for England should themselves be kept living meagre lives on a bare pittance, producing "illth" 242 for those who did not know the value of the wealth at their disposal.

Headlam called to the workers to stand up for their lawful place in society. Jesus had seen something worthy of respect in every person, however low in social status, he reminded his listeners, and Baptism declared every child to be the equal of every other. In Headlam's eyes, the social superiority of the leisured classes was unfounded and he encouraged his working class audience to beware of assuming that "the idlers" were their betters. Christ had taught his followers that a poor sick beggar might really be a better man than a rich millionaire ${ }^{243}$. It was the labourer who through his or her toiling satisfied the nation's material needs, while the leisured classes lived wasteful lives off the wealth of their forefathers. "Let all men and women who are engaged in any of the multitudinous complicated businesses and industries of modern life", he demanded, "let them make much of themselves, maintain their self-respect, hold their heads higher than the idler, and refuse to be patronised by him." ${ }^{244}$

But with all his campaigning for the dignity and equality of the poor, Headlam was equally loath to tipping the balance of social and political equality in the other direction, a danger he perceived in some sections of the Labour and socialist movements ${ }^{245}$. In his eyes, an exaltation of the working classes as working classes would be just as counterproductive and exclusive as the present social system. The workers, he believed, were properly speaking not a class at all, but the great mass of the community upon whom the leisured classes depended for their existence. ${ }^{246}$ To speak of a working class with class distinctions in the popular sense and to demand their emancipation would harm the cause of the Kingdom of God as much as did the present dominance of the leisured classes. He fiercely opposed the Labour Party which he perceived as yet another instrument of divisionism. He considered special legislation in the interests of a so-called working class to be as unfair as class legislation in the interests of the rich. "Why, for instance", he asked, "should special trains and special trams be provided for compositors and engineers and not for clerks and teachers?"247 To vote for a man solely because he held the same job or earned the same wage did not ensure that, as Member of Parliament, he would do the right things and legislate in the interests of the common good, Headlam argued. The benchmark of a good politician and a good political party, he held, was not whether they honoured labour, but whether they aimed at bringing about a more

\footnotetext{
${ }^{242}$ Headlam, Stewart Duckworth, The Guild of St. Matthew, an appeal to Churchmen. Being a sermon etc, 1890, p.10

${ }^{243}$ Headlam, Stewart Duckworth, The Secular Work of Jesus Christ, his apostles and the Church of England, 1886, p.11

244 Headlam, Stewart Duckworth, The Meaning of the Mass. Five lectures, with other sermons and addresses, 1905, p. 113

245 Headlam, Stewart Duckworth, The Socialist's Church, 1907, p.72

${ }^{246}$ Headlam, Stewart Duckworth, The Labour Party, 1892, p.196; see also Headlam, Stewart Duckworth, The Socialist's Church, 1907, p.72

${ }^{247}$ Headlam, Stewart Duckworth, The Socialist's Church, 1907, p.74
} 
equitable state of affairs. A bricklayer did not necessarily make a better politician than a railway director and the qualities of a capable Labour politician like John Burns did not derive from the fact that he had once been an engineer, but from his dedication to the right issues and reforms ${ }^{248}$.

Headlam openly campaigned against Labourism and admonished his listeners to think carefully about possible repercussions before casting their votes. As the general election approached in 1892, he used his journal The Church Reformer to urge his working class readers to vote for the Liberal candidate in their constituency lest the Labour candidate split the vote and worked in favour of the Conservative party. The common good sometimes demanded of a man that personal interests be put last. "You would be false to the Christian religion and your political duty", he went as far as to say, "if you throw away votes on the good man and the Labour man and let in the Tory." ${ }^{249}$ Under a oneballot voting system, one could not afford to vote for a candidate simply because he was a good husband and father or because he agreed entirely with every aspect of the Labour programme. It was the Christian duty of franchise-holders, Headlam urged, to vote for the candidate who was most likely to get into Parliament who was still acceptable in his political agenda. In his eyes, this candidate most often belonged to the Liberal party.

Headlam derived a hopeful message from the Bryant and May strikes of 1888. Even after the strike's conclusion, the working girls still often received less than a living wage and he thus dared not call the strike an economic success or a victory of justice over exploitation. But the strike had managed to bring together society in support of some of its most destitute members. All classes of people had united to help the match girls in their campaign. The entire spectrum of progressive political groupings had collaborated to support them in their demand for a fair wage. The poor match girls had managed to bridge ideological and class divisions and thus had made possible an example of the fact that brotherhood and solidarity were indeed possible and not only the utopian dream of religious or political fanatics ${ }^{250}$. The public demonstration of a common aim constituted the real victory of the match girls' strike in Headlam's opinion.

d) Education: Schools for the People

Two concrete secular reforms took up places of prominence in Headlam's political agenda: the right of every child born into society to a free, secular and comprehensive education and, secondly, the idea of a Single Tax on land values on a Georgeist model. Headlam served as representative for the

\footnotetext{
248 Headlam, Stewart Duckworth, The Labour Party, 1892, p.195f.

249 Headlam, Stewart Duckworth, The General Election, 1892, p.147

${ }^{250}$ Headlam, Stewart Duckworth, The Bryant and May Strike, 1888, p.171
} 
Progressive Party on the London School Board from 1888 onwards $^{251}$. There, he stood up for the concept of what he called "people's schools"252. The 1870 Education Act, he argued, had not been passed in order to give a poor education to the children of the poor, but a sound, secular and broad education to the children of the nation. In his educational endeavours, Headlam aimed at righting the present imbalance of opportunity which resulted from class divisions and the inequality in the distribution of material wealth. He campaigned for the abolition of school fees and asked for the schools to be paid for out of local rates and taxes. The new schools established under the Forster Act were meant for all children, not as a charity for the poor, Headlam insisted, and all members of society should take on their fair share of the $\operatorname{costs}^{253}$.

Of course, free and compulsory education could not in itself raise wages, abolish famine and improve housing, Headlam conceded. But he hoped that knowledge and education would help to make the poor thoroughly discontented with their situation and the entire set-up of society. "We school them to a large degree with this in view", Headlam wrote, "that they may know what is the evil they have to attack and how to attack it." ${ }^{254}$ Headlam believed that if a generation of young people grew up fairly well educated and thoroughly discontented, the legal, orderly, social revolution at which he aimed was bound to happen ${ }^{255}$. He bristled at arguments which claimed that free and compulsory schooling would educate the poor above their station. It was in fact, he countered, the very purpose of common schooling to educate the poor above their station, "not, indeed, above that state of life into which it shall please God to call them, but above that into which devilish robbery and monopoly has forced them" 256 . Common schooling, he hoped, would to some degree help to close the gaps between the classes; it would reduce the children of the middle classes to the place suited to their ability while raising the children of the working classes to a station which presented them with more choices and opportunities than they had hitherto enjoyed.

His belief in the sanctity of humanity and the dignity of the individual led Headlam to take a holistic approach to education. He aimed not only at educating efficient labourers, skilful artisans and successful businessmen who would consolidate England's supremacy in the world market. He hoped to educate the nation's children to a degree that they "should all, as far as possible, get a refined and noble pleasure out of life". "[I]ntelligence, feeling, conduct - these are the things we are after", he specified, "these are the qualities which your Board Schools are intended to develop."257

251 Orens, John, Stewart Headlam's radical Anglicanism, 2003, p.109

${ }^{252}$ Headlam, Stewart Duckworth, The London School Board in 1890: an address, etc, 1890, p.6

253 Headlam, Stewart Duckworth, Free Education, 1891, p.123

${ }^{254}$ Headlam, Stewart Duckworth, Christian Socialism: a lecture, etc, 1892, p.17

255 Headlam, Stewart Duckworth, The Socialist's Church, 1907, p.78

${ }^{256}$ Headlam, Stewart Duckworth, Christian Socialism: a lecture, 1892, p.17

257 Headlam, Stewart Duckworth, The Meaning of the Mass. Five lectures, with other sermons and addresses, 1905, p.86 
Schooling should be humane and general, training the intelligence as well as firing the imagination, refining emotions and forming character ${ }^{258}$. Education enabled the child to discover and develop every aspect of its individuality. Headlam considered a comprehensive system of education a matter of national significance. Today's children would grow into the citizens of tomorrow, and Headlam believed it essential that all young citizens should enter into their heritage well trained in mind and body. He promised his readers that every dime spent on education would be repaid in sovereigns not least from saving on prisons and penitentiaries ${ }^{259}$.

Headlam considered it a matter of prime importance that school leaving age should be raised to eighteen as was the case, for instance, in Scotland. For further education after the end of compulsory schooling, Headlam envisaged evening and continuation classes ${ }^{260}$. It remained for the nation to restrict hours of labour - by the pressure of public opinion or by law - for young men and women up to the age of twenty one so as to enable them to attend evening school ${ }^{261}$. Adult labourers, too, should be given every opportunity to continue their education, mental, physical and technical. Headlam called for "intellectual communism" to accompany the material communism he demanded $^{262}$. Educational exclusiveness stood in the way of the nation's progress as much as did useless wealth and abject poverty, he argued. "We are hindered", he wrote, "because men are not eager that the spiritual wealth of the nation should be shared, but are content that the few should have [every opportunity for refinement], and leave the many to the pleasures of bad beer and vulgar gambling." ${ }^{263}$ In Headlam's vision of a socialist society, the contrast between the spiritually rich and the spiritually poor would no more be allowed to continue than the contrast between the comfortably off and the destitute.

e) The Land Monopoly: A Crime against the Community

The main plank of Headlam's political agenda was the idea of a Single Tax on land values on a Georgeist model. "Our study of social and political questions in the light of the Incarnation", Headlam wrote, "has led us (...) to this truth: that the main cause of the misery and poverty of which

\footnotetext{
${ }^{258}$ Headlam, Stewart Duckworth, The Socialist's Church, 1907, p.77

259 Headlam, Stewart Duckworth, The London School Board in 1890: an address, etc, 1890, p.16

${ }^{260}$ Headlam, Stewart Duckworth, The Meaning of the Mass. Five lectures, with other sermons and addresses, 1905 , p. 21

261 Headlam, Stewart Duckworth, The London School Board in 1890: an address, etc, 1890, p.4

${ }^{262}$ Headlam, Stewart Duckworth, The Meaning of the Mass. Five lectures, with other sermons and addresses, 1905, p.33

263 Headlam, Stewart Duckworth, The Meaning of the Mass. Five lectures, with other sermons and addresses, 1905, p.124
} 
I have spoken and against which the Church exists to fight, is the monopoly of the few of those land values which are intended for the use of all. ${ }^{264}$ Headlam agreed with Henry George that earth was a gift of God to mankind to be used in the interests of the community and to the common good. God was jealous, he warned his readers, when he found that men had allowed the most valuable of his gifts to be "filched away (...) by the Duke of This and the Lord of That" 265 The land was the Lord's and therefore not the landlord's George had proclaimed, and Headlam agreed with the American that private property in land was inherently wrong and unjustifiable.

Headlam summed up his position on the land question in a resolution for the English Land Restoration League: "[T]he main cause of poverty, both in the agricultural districts and in the great centres of population, is the fact that the land, which ought to be the common property of all, is now monopolised by the few; and (...) therefore those who want to cut away at the root of poverty must work to restore to the people the whole of the value which they give to the land, to get for the people complete control over the land and to that end see to it that those who use land pay for the use of it to its rightful owners, the people." ${ }^{266}$ He proposed a single tax on land of 20s in the $£$ intended to restore to the community, its rightful owners, the whole of its economic value for communal use.

Headlam equated the monopoly in land with a de facto monopoly in the main means of production. As such, it lay at the bottom of most economic and social problems in modern Britain and hindered the nation's progress. In his opinion, low wages and sweating could be traced back directly to private ownership of land. By keeping the labourer off the land in the countryside, he explained, landowners forced the workers to migrate into the city where, unskilled in industrial employment as they were, they increased the number of casual labourers and blacklegs and forced down wages in easy-access trades such as dock labour ${ }^{267}$. Against the background of economic monopoly, the most potent weapons of labour, like strikes and trade union action, constituted but inadequate means to reverse the constant worsening of living conditions. "While the means of production (of which land, of course, is the chief) are monopolised by the few", Headlam predicted, "all the strikes and unions in the world will not prevent wages from being low or rent from being high." ${ }^{268}$

Headlam hoped that once land, or the equivalent of its value, was in the hands and at the disposal of the people, the "iron law of wages" would finally be overcome. Instead of labourer competing with

\footnotetext{
${ }^{264}$ Headlam, Stewart Duckworth, The Guild of St. Matthew, an appeal to Churchmen. Being a sermon etc, 1890, p.12

265 Headlam, Stewart Duckworth, Christian Socialism: a lecture, 1892, p.25

${ }^{266}$ Headlam quoted this passage in various of his writings. See e. g. Headlam, Stewart Duckworth, Christian Socialism: a lecture, 1892, p.19; see also Headlam, Stewart Duckworth, Fabianism and land values: a lecture delivered to the Fabian Society on October 23rd, 1908, 1908, p.16

${ }^{267}$ Headlam, Stewart Duckworth, The Guild of St. Matthew, an appeal to Churchmen. Being a sermon etc, 1890 , p.13

${ }^{268}$ Headlam, Stewart Duckworth, The Church and Socialism, 1890, p.224
} 
labourer forcing down wages to the absolute minimum any worker would agree to, employers would have to compete with each other for labour and wages would go up ${ }^{269}$. Headlam cited the example of the Kaffir tribe in South Africa who, having access to land, refused to work in the mines except under conditions which suited them. With his reform proposals he hoped to elevate the British labourer to a similarly strong bargaining position.

The idea of a tax on land values, as opposed to for instance the nationalisation of land, circumvented the problem of property rights and demands for compensation. Rather than expropriate or expel the landlords, a tax on value would seize for the community any profits derived from the use or selling of land. Headlam envisaged that by this method the community could right the century-old ,robbery of the people“ without encountering legal difficulties or having to expose itself to the analogous accusation of unlawful appropriation.

In Headlam's eyes, historic practice and tradition did not sanctify the present system of private ownership in land. He believed that the conferring of land in historic times upon individuals was a crime against future generations. People in the past had no right to give away the land upon which their descendants would depend for a living. "The land of every country", Headlam argued, "belongs by natural and inalienable right to the whole body of the people in each generation." ${ }^{270}$ In addition, in past centuries, land had been conferred not by the nation, the true owners of it, but by the king for services rendered in the army, the navy, the civil service or in the province of poor relief. Nowadays, such services were rendered by professionalised bodies such as the army, the civil service, or the poor law boards, but land was still in the hands of the sons and daughters of erstwhile servants of the king ${ }^{271}$. Headlam believed the situation to be unjustifiably wrong and harmful.

Headlam argued that the value of land - apart from its inherent qualities like fertility or minerals to be found in the ground - was a social value, created by the community which lived and worked on the soil. It was the demand after the land in conjunction with the financial capacity of would-be users which made land in Belgravia more valuable than in Bethnal Green, and land in Bethnal Green dearer than in Epping Forest. Thus, land in the countryside was often worth less than forty shillings per acre per year, while the value of some plots in the cities amounted to thirty pounds per foot. ${ }^{272}$. Some areas near the centre of London could be let for a rental which per acre approached forty-thousand pounds per annum. Headlam held that income derived from such an increase in value - an income usually received in the form of rent - was in the truest sense of the word

\footnotetext{
${ }^{269}$ Headlam, Stewart Duckworth, Christian Socialism: a lecture, etc, 1892, p.20

270 Headlam, Stewart Duckworth, Christian Socialism: a lecture, 1892, p.23f

${ }^{271}$ Headlam, Stewart Duckworth, Christian Socialism: a lecture, 1892, p.23f; see also Headlam, Stewart Duckworth, The Taxation of Land Values, 1888, p.87

272 Headlam, Stewart Duckworth, The Taxation of Land Values, 1888, p.87; see also Headlam, Stewart Duckworth, Christian Socialism: a lecture, 1892, p.21
} 
"unearned", and thus undeserved, by the landlord. The huge values of the land of, for instance, London which had no basis other than society's demand for it, belonged "of natural and inalienable right, not to those who now happened to possess them, but to the whole body of the people who create them by their presence and by their industry"273.

Headlam called for an independent valuation of land in towns, suburbs and countryside followed by a taxation of these land values ${ }^{274}$. Land values were already being rated for local purposes. Yet, the value of land determined for local rates and taxes was enmeshed with the value of improvements on the land such as buildings or infrastructure. Headlam cited evidence given before the Town Holding Committee in 1887 by one William Saunders. Using the example of fifty-nine cases as a basis for his calculations, Saunders showed that the value of land in the metropolitan area amounted to an estimated $£ 418 \mathrm{~m}$, while the value of the buildings and improvements ran to $£ 212 \mathrm{~m}$. The occupiers of the houses paid taxes of approximately $£ 7 \mathrm{~m}$ a year, while the owners of land paid but $£ 0.5 \mathrm{~m}$ in income tax and a nominal land tax ${ }^{275}$. The distribution of the burden of rates and taxes was clearly unfair, Headlam argued. More seriously still, the present system of land valuation meant a very real loss to the community.

Secondly, to tax the value of land only in conjunction with the value of improvements on it seriously underrated vacant plots might in itself be of enormous value. The practice encouraged owners of vacant plots to withhold them from the market against the best interests of the community until they were able to extort from the public needs an enhanced selling or letting price. ${ }^{276}$ Headlam quoted a recent estimate by the London County Council to the effect that in 1889 , there were three hundred acres of land held idle in Westhampstead. Vacant plots in Kensington amounted to a value of about $£ 1.7 \mathrm{~m}$ per year. Under the present system of valuation, he pointed out, the acres in question paid but three percent of what they would pay under a system of independent valuation of ground values. "If valuable land required for building is used only for grazing cows the landlord is injuring the community by preventing the land from being put to its best use"277, Headlam concluded. A valuation of ground values independent of improvements on the land, he predicted, would force many of these hitherto fallow plots into the market. Headlam hoped to thereby alleviate, among other issues, the problem of housing. "Under the housing question lies the land question, as surely as the house stands on the land"278, he asserted. New acreage on the market, he envisaged, would

\footnotetext{
${ }^{273}$ Headlam, Stewart Duckworth, The Guild of St. Matthew, an appeal to Churchmen. Being a sermon etc, 1890, p.13

274 Headlam, Stewart Duckworth, Fabianism and land values: a lecture delivered to the Fabian Society on October 23rd, 1908,1908, p.8

275 Headlam, Stewart Duckworth, The Taxation of Land Values, 1888, p.176

276 Headlam, Stewart Duckworth, The Taxation of Land Values, 1888, p.174

277 Headlam, Stewart Duckworth, Land Values and How To Tax Them, 1889, p.178

${ }^{278}$ Headlam, Stewart Duckworth, The Lambeth Conference and Socialism, 1888, p.181
} 
lower the pressure on existing tenements by providing more space for new buildings in or near over-crowded neighbourhoods and cut down rents by reducing competition.

In Headlam's eyes, land reform took pride of place over all other reforms, including the nationalisation of industry. Any questions relating to industrial capital, he believed, were intricately linked to the problem of land monopoly and would be solved by an abolition of the latter. Factories and workshops, roads, railways and canals, he explained, all stood on the land. If the people resumed their rights over the land, they would automatically resume their rights over those also. It was foolish, Headlam argued, to put the cart before the horse. "If you want to socialise the milk, you had better first socialise the cow"279, he advised his fellow-reformers. The socialising of land values had to take precedence over every other nationalisation, he argued, and when it was accomplished, many reforms urgently called for at present would have been accomplished or become obsolete without further action. By contrast, he warned, reforms forced through before the land question was solved might not only fail, but be positively harmful and play into the hands of the landowner. He listed the example of Waterloo Bridge: its communising had resulted in the rents of those who used to pay toll being raised. Improved transit to the suburbs, too, tended to increase the amount which the landlord could appropriate from the workman ${ }^{280}$.

Headlam warned his contemporaries against watering down socialism to what he called a mere "bureaucratic Collectivism". Nothing but recapturing the whole of the land, the main means of production, for the use of the people would, he believed, solve the problem of industrial slavery. Socialism was something very different from the "dominance of the official over enterprises or industries owned or supported by the Municipalities or the State" ${ }^{\text {281 }}$. He feared that piecemeal reform of the above kind, often rushed through by people anxious to do something in a hurry without considering the consequences, might prove harmful and delay the changes necessary on the path towards a true Kingdom of Heaven upon earth ${ }^{282}$. Some public management of selected industries and common property was, Headlam conceded, indeed useful. He mentioned municipal control of trades such as gas, water, transport and milk which would ensure the fair and reliable supply of all with some of the basic necessities of modern life. Parks and open spaces, too, should be supervised by public bodies, as should sanitary and health conditions. Building Acts and Factory Laws, he envisioned, would to a certain degree have to regulate the use of the land. But Headlam

\footnotetext{
279 Headlam, Stewart Duckworth, Fabianism and land values: a lecture delivered to the Fabian Society on October 23rd, 1908, 1908, p.4

${ }^{280}$ Headlam, Stewart Duckworth, Fabianism and land values: a lecture delivered to the Fabian Society on October 23rd, 1908, 1908, p.10

281 Headlam, Stewart Duckworth, Fabianism and land values: a lecture delivered to the Fabian Society onOctober 23rd, 1908, 1908, p.3

${ }^{282}$ Headlam, Stewart Duckworth, The Socialist's Church, 1907, p.57
} 
was adamant that such control should be "Democratic and not Bureaucratic", executed by the people's own elected representatives rather than by some powerful civil official ${ }^{283}$. Men whose idea of social reform focused on the multiplication of licences and inspectors and who aimed at administrating rather than liberating the people might, Headlam admitted, be doing valuable work for the present, but in the long run harmed the cause of socialism by causing serious prejudice against $\mathrm{it}^{284}$.

\section{The Limits of Socialism and the Kingdom of Heaven}

But for all his political radicalism and socialist sympathies, above all, else, Headlam remained a theologian and a believer in the message of Christ. Socialism for him remained but a means to a higher end. The Kingdom of Heaven upon Earth, towards which Headlam was working, implied more than land reform, improved education and the redistribution of material wealth. In Headlam's view, the industrial revolution constituted but the forerunner to a spiritual revolution. "The Kingdom of Heaven which is to be established on Earth will not be established by the accomplishment of Socialism", he wrote. "[R]ather is it Socialism which is necessary in order that all may have time to think about the Kingdom of Heaven and enjoy it." ${ }^{285}$

Headlam believed that the people needed to be given bread, coats, shoes and homes for their bodily welfare in order to free their minds and energies for the enjoyment of the other gifts of God. The most important aim to be achieved in Headlam's eyes was not material comfort, but for the individual to be free to develop his or her potential to the fullest and to live a higher spiritual live. This, then, was the answer Headlam provided for the question about the essential difference between socialists and Christian Socialists. For Headlam, it rooted in the motive power behind agitation for political reform and in its ultimate aim: while the economic socialist considered achieving an equality of material conditions to be the end in view, the Christian Socialist took the accomplishment of material justice as a means towards a higher communal life ${ }^{286}$.

Headlam hoped that in the Kingdom of Heaven on earth, true individualism would at last assert

\footnotetext{
${ }^{283}$ Headlam, Stewart Duckworth, Fabianism and land values: a lecture delivered to the Fabian Society onOctober 23rd, 1908, 1908, p.9

${ }^{284}$ Headlam, Stewart Duckworth, The Socialist's Church, 1907, p.55

285 Headlam, Stewart Duckworth, Fabianism and land values: a lecture delivered to the Fabian Society on October 23rd, 1908, 1908, p.13

286 Headlam, Stewart Duckworth, The Church and Socialism, 1890, p.220
} 
itself. The modern competitive system of industry had, he argued, thoroughly suppressed any budding of individual character, capacity and creativity. He believed that under socialism the individual would enjoy much more freedom to discover his or her real potential: "there would be an abundance of leisure for physical, moral and spiritual development"287, he predicted. Humanity itself would finally be able to expand in all its various facets. The „sordid conditions“ caused by poverty as well as the ,vulgar conditions“ caused by riches, the callousness stemming from the determination of the few to enjoy themselves as much as the ignorance and crudeness inherent in the life and pastimes of the poor, Headlam dreamed, all the conditions which had favoured vice, ugliness and narrow-mindedness under a capitalist economy would give way to beauty and virtue in mind and body ${ }^{288}$. This was Headlam's vision of the Kingdom of Heaven established upon earth and his interpretation of the Christian phrase „eternal life“.

Headlam believed that in the imminent social revolution, the Church was earmarked for a leading role. He impressed on his readers that she was the "great society organised for the material and spiritual well being (...) of the world" ${ }^{289}$. As a nation-wide institution, comprising members of all classes and all facets of political opinion, the church constituted in his opinion the greatest conceivable instrument of social reformation. Headlam encouraged his fellow churchmen to show that the reforms and changes needed for the material well-being of the people, were fully sanctioned by her dogma and catechism. So far from men having to go outside the church to realise them, he postulated, the church should in fact be the most powerful agent for getting them carried out ${ }^{290}$.

The desertion and absence of those men and women most interested in getting rid of social and industrial disorders harmed the church by leaving her in the hands of the few content with consolidating the status quo. "The people are fatally to blame", Headlam lamented, "for allowing the great instrument of Social Progress to be run in the interest of the idle monopolising classes."291 Headlam called for his socialist contemporaries to reclaim the church as theirs and to remind her of her proper aims and principles. ${ }^{292}$ When Socialists recognised their membership in the church, lived in each parish as a united body and claimed their rights to carry on on a large scale Christ's exemplary work of human deliverance, then, Headlam believed, the Social Revolution would surely be accomplished ${ }^{293}$.

\footnotetext{
${ }^{287}$ Headlam, Stewart Duckworth, The Socialist's Church, 1907, p.68

${ }^{288}$ Headlam, Stewart Duckworth, The Socialist's Church, 1907, p.68

289 Headlam, Stewart Duckworth, The Church and Socialism, 1890, p.222

290 Headlam, Stewart Duckworth, The Meaning of the Mass. Five lectures, with other sermons and addresses, 1905, p. 123

291 Headlam, Stewart Duckworth, The Socialist's Church, 1907, p.17

${ }^{292}$ Headlam, Stewart Duckworth, The Socialist's Church, 1907, p.48

${ }^{293}$ Headlam, Stewart Duckworth, The Socialist's Church, 1907, p.15
} 
The idea that social reform constituted only a preliminary step on the way towards a higher, spiritual renewal of the nation figured prominently also in the thought of another cleric: William Booth, founder of the Salvation Army. Booth, too, felt inspired by his religious belief in his fight against poverty and destitution. Unlike Headlam, he did not belong to the Christian socialist tradition, but came from an evangelical background. In the following chapter, I shall examine the relation between his religious and social thought and his proposals for reform which he laid out in his bestselling book In Darkest England and the Way Out. 


\section{A. Christian Socialists}

\section{Chapter 3 - William Booth and In Darkest England}

\section{Biographical Data: William Booth}

The second thinker to be examined in the category of Christian socialists is William Booth, the founder of the Salvation Army ${ }^{294}$.

While Stewart Headlam developed an intellectual groundwork for his social and political views from academic theology, William Booth's beliefs, spiritual as well as social, were of an essentially practical nature. First and foremost, Booth was an evangelist. In all his activities, he aimed at the saving of individual souls. Booth did not concern himself greatly with intellectual subtleties and theological - or social - theory. His sphere of action was not the lectern or the pulpit, but the streets of the neighbourhood and the village green. His revival meetings, frequently held open air, were enormously popular with the working people, not least for the entertainment they provided with brass bands and spectacular public conversions. Booth spoke the language of the working classes and in his methods and his message he met their needs and tastes.

By contrast to Headlam who built his religious and social creed upon the idea of the perfect humanity of Christ and the sanctity of the secular world, Booth held fast to a thoroughly otherworldly religion. His focus lay on the spiritual state and the soul, rather than the body, of his neighbours. But to reach the souls, he came to learn in the course of his labours among the poor of East London, one sometimes had to work through the body. It was in response to the destitution and misery which he and his fellow-Salvationists saw during their slum missions and evangelising tours to the Black Country, the coal pits of Wales and to the East End of London that he developed a scheme of social reform. His aim was to free man of his earthly worries in order to enable him to care for his spiritual salvation. For Booth, poverty was the result as well as the breeding ground of

\footnotetext{
${ }^{294}$ For background information on William Booth's life and work, see e. g. Walker, Pamela J., Pulling the devil's kingdom down: the Salvation Army in Victorian Britain, 2001; Murdoch, Norman H., Origins of the Salvation Army, 1995; Hattersley, Roy, Blood and fire: the story of William and Catherine Booth and their Salvation Army, 1999; Green, Roger Joseph, The life und ministry of William Booth, 2005; Woodall, Ann M., What price the poor?, 2005
} 
the devil's work and thus stood in the way of salvation. In his book In Darkest England and the Way Out, published in 1890, Booth therefore laid out a plan of social amelioration designed to benefit the body in order to save the soul.

Throughout his life, William Booth was an independent spirit. Born in 1828 to Anglican workingclass parents in Nottingham, he converted to Methodism at the age of fifteen. For nearly twenty years, he worked as an itinerant lay preacher and ordained evangelist for the Wesleyans, the Independents, the Methodist Reformers and the Methodist New Connexion, but could not, in the end, submit to any authority other than his divine calling. In 1862, he finally broke with established Methodism and settled in London where, in cooperation with his wife Catherine, he opened the nondenominational East London Christian Revival Association. With the Association, the Booths originally aimed solely at converting the masses, sending the newly saved on to their neighbourhood churches for the future care of their souls. Experience showed, however, how short-lived those conversions could be unless they were followed up by intense care and spiritual support. Booth began to integrate new believers into his missionary work, thus serving the double purpose of keeping them motivated, as well as vastly expanding the human resources of his Association.

By 1878, Booth had assembled a team of devotees large enough to form an independent denomination. He named it The Salvation Army. In remodelling the Revival Association along the lines of the imperial army, Booth cleverly seized upon the positive connotations of physical robustness, bravery, cleanliness, discipline and a sense of mission attached to military life in colonial Britain, all of which formed part of his own grand design for spiritual salvation. Booth introduced military ranks, banners and uniforms and declared his evangelists to be "soldiers in the eternal war against sin". The success of the Army proved him right: membership figures rose from an estimated 5000 in 1875 to 100.000 in 1900 and 115.000 in 1911; attendance at services far outnumbered the above data. ${ }^{295}$. The number of full-time paid officers increased from 128 in 1878 to 2868 in 1906. They were helped by a myriad of volunteers running, as Booth stated in 1896, up to $40.000^{296}$. The Army's official organ, the War Cry, started off with a circulation of 20.000 copies weekly, a figure which increased to 110.000 within a year ${ }^{297}$. With the help of his eight children and his wife Catherine, Booth took the Salvation Army abroad and opened branches in the US, continental Europe, South Africa, India and Japan.

William Booth died in London on October 20, 1912.

\footnotetext{
295 Walker, Pamela J., Pulling the devil's kingdom down: the Salvation Army in Victorian Britain, 2001, p.49. In a conversation with William Gladstone in 1896, Booth gave the possibly somewhat optimistic estimate of four to five million attendees per week at 36.000 prayer meetings internationally. See Booth, William, A Talk with Mr. Gladstone at His Own Fireside, 1897, p. 21

296 Booth, William, A Talk with Mr. Gladstone at His Own Fireside, 1897, p.17, Fn

297 Walker, Pamela J., Pulling the devil's kingdom down: the Salvation Army in Victorian Britain, 2001, p.69
} 


\section{The Salvation Army: Caring for the Soul through the Body}

The Salvation Army provided Booth with a unique key to the needs, realities and culture of the working classes. The instruments of attracting attention and drawing the working classes near as well as the straightforward, easy-to-grasp religious doctrines used by the Army allowed Booth unrivalled access to the inhabitants of the poor urban neighbourhoods and the industrial mining districts.

Salvationist theology and religious practice held an emotional appeal unparalleled by established denominations. By contrast to Stewart Headlam, Booth failed to construct grand theological systems, but emphasised individual doctrines which served him and his followers as signposts towards a sanctified life. From his Wesleyan background, Booth retained a faith in the universal love of God and the possibility of salvation for all. From evangelicalism, he borrowed the emphasis on the individual soul. He was also drawn to the highly emotive approaches of holiness theology and revivalism which had been re-imported into England in the first half of the nineteenth century by American evangelists ${ }^{298}$.

The historian of Salvationism Roy Hattersley has argued that holiness theology provided an ideal vehicle for converting semi-educated working men and women. It did away with long periods of study, theological arguments and private contemplation ${ }^{299}$. For clerics of the above persuasion, sanctification was a gift from God bestowed instantaneously upon the truly repentant sinner. It only required the individual's willingness to lay "body, soul and spirit with all their redeemable powers upon Thine altar to be forever Thine" ${ }^{" 300}$. In a second step, the newly saved could then achieve personal holiness or "entire sanctification" by acquiring the power to resist all future temptation. Ultimately, holiness theologians preached, conversion and sanctification would free men and women from sinful and ruinous bodily cravings such as drink, tobacco, physical aggressiveness and licentiousness and would teach them the virtue of cleanliness, which in many Victorian eyes was the outer manifestation of godliness.

Impromptu public preaching and open air services brought the revivalist message to the streets. Humour was deemed essential during services, heckling and spontaneous comments from the

298 In his book Blood and fire: the story of William and Catherine Booth and their Salvation Army, the historian Roy Hattersley names the American revival preachers James Caughey (1810-91), Charles Finney (1792-1875) and Phoebe Palmer (1807-74) as formative influences on William Booth's style of preaching. See Hattersley, Roy, Blood and fire: the story of William and Catherine Booth and their Salvation Army, 1999, p.104ff

299 Hattersley, Roy, Blood and fire: the story of William and Catherine Booth and their Salvation Army, 1999, p.104ff

300 Phoebe Palmer as quoted in Hattersley, Roy, Blood and fire: the story of William and Catherine Booth and their Salvation Army, 1999, p. 105 
audience were encouraged. During their prayer meetings, preachers went from pew to pew praying with individuals, asking them to come forward to relate their personal experiences. Booth used revivalist practices in his work at Whitechapel turning Salvationism into a true "neighbourhood religion" ${ }^{301}$ designed to convert entire streets and districts.

But it was not only the religious message he preached which moved Booth nearer to the working classes than were most other religious agencies in Victorian England. Unlike many other urban mission stations and travelling preachers, Booth and the Salvation Army did not in their evangelising work try to force middle-class values and understandings of respectability and propriety onto the masses. Conversions among working men and women, Salvationists believed, were best effected by "people of their own class, who would go after them in their own resorts, who would speak to them in a language they understood, and reach them by means suited to their own tastes" ${ }^{302}$. Booth summed up the Army's unusual proximity to the poor: "We are among the people, of the people, and are therefore able to judge the people." 303

Booth and his associates plundered working-class culture in pursuit of catchy and inviting vehicles for their religious message. They rented music halls, theatres and pubs for their services such as the Eastern Alhambra at the Army's Limehouse station ${ }^{304}$. In their posters and publications, they borrowed the sensationalist style and idiom of penny gaffs and circuses. Brass bands accompanied services and processions. Booth and his colleagues snatched popular music hall tunes and equipped them with religious words to be sung at the Army's numerous services and meetings. The Salvation Army was also among the very first religious communities to make use of the new medium of film. By 1906, a hurriedly established Salvationist cinematograph department had produced seventy-four promotional films and had purchased three hundred and twenty one commercial ones covering topics as diverse as the Army's work, an outing to the London Zoo, the coronation of Edward II. or the making of a motor car $^{305}$. Their use of film proved particularly effective in drawing crowds of adolescents to Salvationist services.

Booth gained his unique insights into the culture and living conditions of the British working classes through his practice of using converts in his evangelising work ${ }^{306}$. The Army sent off the recently saved into their old environments to publicly relate their experiences. The practice enabled Booth and his Christian Mission to make inroads into the urban working-class neighbourhoods to

\footnotetext{
301 Walker, Pamela J., Pulling the devil's kingdom down: the Salvation Army in Victorian Britain, 2001, p.56

302 McLaughlin, Joseph, Writing the Urban Jungle: Reading Empire in London from Doyle to Eliot, 2000, p.91

303 Booth, William, Emigration and the Salvation Army, 1906, p.18

304 Murdoch, Norman H., Origins of the Salvation Army, 1995, p.55

305 Rapp, Dean, The British Salvation Army, The Early Film Industry and Urban Working Class Adolescents, 18971918, 1996, p.161

306 Murdoch, Norman H., Origins of the Salvation Army, 1995, p.148ff.
} 
an extent which none of the other religious establishments could achieve. Salvationists penetrated the closely knit network of relations with family members, neighbours and colleagues which formed a working man's or woman's environment. In this respect, women evangelists proved a particular asset to the Army. Mothers and housewives welcomed them into their living quarters more easily than men and were more open with them about a family's particular problems. The knowledge of working class culture which Booth and the Salvationists gathered in the course of their work formed the nucleus and background to the social scheme advanced in In Darkest England and the Way Out. Social endeavours were not new to William Booth when he wrote In Darkest England in 1890. Already the Christian Mission, predecessor of the Salvation Army, had run soup kitchens, mothers' meetings and friendly societies on a neighbourhood scale, and so did the Army. One of the Army's first formalised social endeavour, the Cellar, Gutter and Garret Brigade ${ }^{307}$, was a semi-professional team of women Salvationists who visited the poor and helped with cleaning work and nursing wherever fellow-missionaries detected need. Army-run food and shelter depots, homes for fallen girls, drunkards and ex-prisoners opened in response to the misery and privation witnessed by Salvationist evangelists.

Initially, William Booth looked upon such initiatives with some contempt as useful tools for drawing in the masses; his aim was - and remained - the conversion of the working classes and the saving of souls. By 1890, however, the reports of his evangelists on their experiences in the poorest districts of the towns had brought Booth to consider the very existence of slum neighbourhoods to be a "satire upon our Christianity" 308 and a "great discredit to our boasted civilisation" 309 . He had come to realise that material conditions and physical suffering may stand in the way of spiritual salvation. "[It] is primarily and mainly for the sake of saving the soul that I seek the salvation of the body" 310 , he asserted in the first part of In Darkest England. What, after all, he asked, was the use of preaching the gospel to one who could not think of anything other than where to find food for the day's meal and shelter for the night: he or she could not hear you anymore than a person whose head was under water ${ }^{311}$. "I am quite satisfied", Booth wrote, "that those multitudes will not be saved in their present circumstances." ${ }^{912}$

Booth began to consider it a "Christian duty" to work against the misery and squalor of so large a section of the English population and to help alleviate some of the suffering. He condemned the apparatus of temples and meeting houses set up by the established denominations "to save men

\footnotetext{
307 Walker, Pamela J., Pulling the devil's kingdom down: the Salvation Army in Victorian Britain, 2001, p.114

308 Booth, William, In Darkest England and the Way Out, 1890, p.16

309 Booth, William, Emigration and the Salvation Army, 1906, p.4

310 Booth, William, In Darkest England and the Way Out, 1890, p.45

311 Booth, William, In Darkest England and the Way Out, 1890, p.45

312 Booth, William, In Darkest England and the Way Out, 1890, p.257
} 
from perdition in a world which is to come while never a helping hand is stretched out to save them from the inferno of their present life" ${ }^{313}$. In response to the abject poverty among much of its clientèle, in 1890, the Salvation Army opened its Social Reform Wing, aiming henceforth at "Salvation for Both Worlds" "314.

Yet, it is important to bear in mind that relief work should always take second place to the saving of souls in Booth's mind. He remained uncertain about the time and energy put into social work and at times wondered whether they would not be better spent on evangelising. As he wrote to his son Bramwell in 1903: "As to whether we get as much real benefit out of the time and labour and ability bestowed upon feeding the poor as we should do if spent in purely spiritual work is a very difficult question to answer." ${ }^{315}$ Ultimately it was his belief in his divine calling and in God's assistance from which he drew his courage to tackle the immense problem of poverty and physical destitution in Britain: "[In] the faith that He has made in His image all the children of men we face even this hideous wreckage of humanity with a cheerful confidence that if we are but faithful to our own high calling He will not fail to open up a way of deliverance."’316

There has been some debate about the authorship of In Darkest England and the Way Out. The journalist and social critic W. T. Stead claimed to have made a significant contribution; shortly after the book's publication he pronounced that one could "recognise my fine Roman hand in most chapters". The end of the first chapter was indeed adopted almost word for word from an article by Stead in the Pall Mall Gazette from October 1883. In addition, recent historical research has established the co-authorship of Frank Smith, a prominent Salvationist and member of the Independent Labour Party (ILP). Smith became first head of the Army's Social Reform Wing; Norman Murdoch, historian of Salvationism, credits him with the original ideas for the colony scheme described in In Darkest England. ${ }^{317}$ Considering Booth's autocratic position within his organisation and given the fact that the text was published under his name, one can nonetheless assume that the views expressed in the book and the remedies suggested represent Booth's own opinion on the subject of poverty and unemployment. In fact, Stead gave Booth full credit as the master mind behind the scheme: "The sole responsibility and the dominating mind was his and his alone." ${ }^{318}$ I shall thus continue to cite Booth as the author of the piece.

\footnotetext{
313 Booth, William, In Darkest England and the Way Out, 1890, p.16

${ }^{314}$ Booth, „Salvation for Both Worlds“, in All the World, Vol.V, No. 1, January 1889, as quoted in Woodall, Ann M., What price the poor?, 2005, p.164

315 As quoted in Woodall, Ann M., What price the poor?, 2005, p.165

316 Booth, William, In Darkest England and the Way Out, 1890, p.35

317 Smith eventually left the Army to dedicate himself to political work and ILP socialism. See Murdoch, Norman H., Origins of the Salvation Army; 1995

318 Murdoch, Norman H., Origins of the Salvation Army, 1995, p.161
} 


\section{In Darkest England and the Way Out: Booth's Social Scheme}

a) The Darkness

Booth divided In Darkest England into two sections. In the first, under the heading The Darkness, he offered a very personal definition of the social question. "The social problem", Booth wrote, "presents itself before us whenever a hungry, dirty and ragged man stands at our door asking if we can give him a crust or a job. That is the social question." ${ }^{319}$ Based on government returns and the figures set forth by Charles Booth in Life and Labour of the People in London, William Booth estimated that about three million men, women and children, in other words about one in ten out of the entire English population, lived in absolute poverty or on the verge of it. Among the "submerged tenth" ${ }^{320}$, as he called them, he included the jobless, casual workers, intermittent earners and small regular earners, gaol inmates and lunatics as well as all those dependent upon any of the above. From the reports of the Army's missionaries who regularly visited working class neighbourhoods, Booth identified homelessness, unemployment, drink and social ostracism as the topics which needed to be addressed most urgently in solving the social problem.

Much of the misery and squalor Booth described in the first section of In Darkest England was not particularly new at the time of publication. Andrew Mearns' The Bitter Cry of Outcast London ${ }^{321}$, W. T. Stead's articles in the Pall Mall Gazette and Charles Booth's Life and Labour had already put issues like the housing situation or sanitary conditions in working class neighbourhoods onto the public agenda. Booth acknowledged his debt to all of the above. His use of reports by Salvationist slum workers to illustrate the problems of poverty, however, added a personal dimension to the issue of pauperism and destitution. Booth's prime concern was for the individual involved, it was "John Jones and his fellow workers" 322 whom he proposed to help. Individual reformation, he believed, must be the guiding principle of any operation aiming at the betterment of society. "Any effort at social reform that does not provide facilities for the regeneration of the individual is", he wrote, "in my opinion, foredoomed to failure." 323

The first section of In Darkest England aimed primarily at catching the attention and stirring the consciences of the better-off. As in his religious addresses, in his appeal for social action, Booth

\footnotetext{
319 Booth, William, In Darkest England and the Way Out, 1890, p.91

${ }^{320}$ Booth, William, In Darkest England and the Way Out, 1890, p.17ff.

321 Mearns, Andrew, The bitter cry of outcast London, 1883; there is some debate about the authorship of the anonymous pamphlet; Andrew Mearns appears to be the most likely candidate and is generally cited as its author.

322 Booth, William, In Darkest England and the Way Out, 1890, p.79

${ }^{323}$ Booth, William, The Salvation Army and Poor Law Reform, 1909, p. 1
} 
aimed directly at his audience's emotions. He employed imagery popular among the sea-faring, imperialist Victorian establishment by likening poverty to shipwreck or the East End to a wild jungle hostile to life. Not only in terms of the book's title did Booth lean heavily upon the BritishAmerican soldier and adventurer Henry Morton Stanley's enormously popular publication In Darkest Africa ${ }^{324}$. The sensationalist report of a survival trip through the African jungle was published a year before Booth's own work. Booth cleverly seized upon the sense of adventure imparted by Stanley's book; he depicted the East End of London as an inimical and threatening environment not unlike the African wilderness housing an aggregation of primitive, sometimes savage, but ultimately reformable tribes in desperate need of a civilising hand. Darkest Africa and Darkest England, Booth told his readers, resembled each other closely: its monotonous dimness, its malaria and its gloom, its dwarfish de-humanised inhabitants, the slavery to which they were subjected, their privations and their misery ${ }^{325}$.

Section One of In Darkest England read like a colonial thriller, appealing to the civilised philanthropist and educator as well as the imperial adventurer within the comfortably-off English middle- and upper classes ${ }^{326}$. "Think for a moment", Booth wrote, "how strange it is that so much interest should be excited by a narrative of human squalor and human heroism in a distant continent, while greater squalor and heroism not less magnificent may be observed at our very doors." ${ }^{327}$ There had been earlier writers on the East End such as Charles Dickens or Henry Mayhew who had likened its landscape and populace to foreign countries and primitive tribes; yet none had employed the imperial metaphor to the same extent and, incidentally, to the same effect as William Booth. Like no other author, Booth dramatised the war against poverty and destitution in a way which seized upon the imagination of a "phlegmatic people" and touched their individual consciences and their sense of national greatness ${ }^{328}$. With the first part of In Darkest England, he managed to make social issues seem as important for the nation's future as, for example, the Irish question.

\footnotetext{
324 Stanley, Henry M., In darkest Africa, or, The quest, rescue and retreat of Emin, governor of Equatoria, 1890. Henry Morton Stanley (1841-1904), born as John Rowlands, went to Africa for the first time in the early 1870s in order to find the Scottish missionary and explorer David Livingstone who had gone missing on a missionising tour for the London Missionary Society. Half a century later, in 1939, his so-called Livingstone expedition was turned into a popular movie with Spencer Tracy playing Henry Morton Stanley. In 1886, Stanley returned to Africa on the Enim Pascha Relief Expedition to rescue the governor of Equatoria in southern Sudan. His book In Darkest Africa recounts his experiences gathered in the course of the Enim Pascha expedition.

325 Booth, William, In Darkest England and the Way Out, 1890, p.12

${ }^{326}$ McLaughlin, Joseph, Writing the urban jungle: reading empire in London from Doyle to Eliot, 2000, p.79-103

327 Booth, William, In Darkest England and the Way Out, 1890, p.12

328 Ausubel, Herman, General Booth's Scheme of Social Salvation, 1951, p. 25
} 
In Section Two of the book, entitled "Deliverance", Booth set out a three-tier scheme designed to deal with the problem of the submerged tenth. He based his Darkest England scheme on the assumption that work, not charity, constituted the only sustainable, regenerative force in the fight against poverty, and the true need and desire of the destitute. In an address to the Royal Colonial Institute in 1906, he reported of his experiences with petitioners to the Salvation Army: "The continual cry of those who appeal to [us] is 'We don't want charity, we want work'." ${ }^{329}$ Labour, he believed, constituted God's plan for mankind and wherever it could be offered, its reformative and restoring effects were unparalleled. Booth's criticised the existing Poor Law provisions: the present system, based on the punitive principle of Less Eligibility, failed to restore to any degree of efficiency, health and self-respect the lapsed classes who claimed its assistance ${ }^{330}$.

The key part of Booth's ameliorative scheme consisted of a three-fold system of labour colonies, to be run in the cities, the country and abroad. He planned them as model of stages where clients could graduate from city to country-side and overseas colonies as they made their way out of poverty and towards an independent self-supporting, dignified life. With his Darkest England scheme, Booth propounded to start reformatory work in the cities and industrial centres where poverty appeared most concentrated and most hopeless. As an alternative to the casual ward of the Poor Law, Booth proposed to establish so-called city colonies as "receiving homes for the destitute" to be run along the lines of the Salvation Army's food and shelter depots ${ }^{331}$. By contrast to the "semi-criminal treatment" ${ }^{\prime 332}$ to which the casual wards subjected their frequenters, the city colony would offer, at the price of fourpence per head, decent meals and a clean place to sleep as well as personal advice and edification where needed. Booth envisaged colonies with a capacity of not more than 200 persons in order to be able to address the inmates as individuals and to see to personal grievances and needs.

Booth expressly rejected the idea of gratuitous distribution of food or free lodging. He carefully dissipated potential objections that his scheme might represent just another form of organised charity. Those too poor to pay for their shelter, he suggested, would be given a chance to earn their keep in workshops and labour yards associated with the depots. Booth pointed to the Army's considerable experience with regard to labour yards of the proposed kind. In the Salvationist Industrial Workshops at Whitechapel, for instance, the organisation employed up to ninety men in

\footnotetext{
329 Booth, William, Emigration and the Salvation Army, 1906, p.6

${ }_{330}$ Booth, William, The Salvation Army and Poor Law Reform, 1909, p.3

331 Booth, William, In Darkest England and the Way Out, 1890, p.94

332 Booth, William, In Darkest England and the Way Out, 1890, p.105f
} 
their habitual trades in return not for wages, but for board and lodging, to help them smooth over periods between regular employment. The goods produced were sold at market price in order to contribute to the costs of the scheme ${ }^{333}$. The city colony, he planned, would operate upon the basic premise of enabling the poor to help themselves without the demoralising effects of alms-giving or the degrading operations of the Poor Law. "Here is no pretence of charity", he proclaimed, "beyond the charity which gives man remunerative labour." ${ }^{334}$ Booth presented his proposal in terms of a personal contract between himself and the individual recipient: so much coffee, so much bread, so much shelter, warmth and light in return for so much money or work. By this method, he hoped to restore the essentials of human dignity to men and women who had for too long, he felt, been treated not as persons, but as cases.

In the city part of the scheme, a labour bureau would eventually supplement the food and shelter depots and labour yards. Booth heavily criticised the lack of a central agency which could ascertain whether there was demand for labour on the regular market. He envisaged that the labour bureau, would register employers as well as job seekers and would thus help to match the demand for particular work with the skills on offer. Through a central agency of the above kind, he hoped to circumvent any delay in finding new jobs which often resulted from a lack of information on both sides, as well as to procure jobs in parts of the city which under current circumstances were unavailable to the unemployed of poorer neighbourhoods ${ }^{335}$.

With the city colonies Booth expected to rescue from social and material downfall a considerable number of the casual poor in industrial centres. Booth described them as "harbours of refuge into which the storm-tossed workman may run and re-fit" ${ }^{336}$ so that he may as soon as possible return to his old environment and to the regular labour market. Those who could not secure normal employment for themselves or who had nowhere to return to would, in Booth's scheme, be sent on to the second stage: the farm colonies. Much land in the British Isles lay fallow which could easily be made arable and sustain a myriad of those who now went without food and shelter in the big cities, he argued. Booth proposed to make use of that land by establishing communal farms along the lines of the city colonies which would receive the surplus unemployed of industrial centres. An estate of five hundred acres within reasonable distance from the London market and with access to the railroads and the sea, he estimated, would easily support up to two thousand people if cultivated to the newest of scientific knowledge. The farming, Booth envisioned, would eventually be supplemented by small-scale manufacturing of bricks, glass or furniture. Surplus produce could go

\footnotetext{
333 Booth, William, In Darkest England and the Way Out, 1890, p.107ff.

334 Booth, William, In Darkest England and the Way Out, 1890, p.106

335 Booth, William, In Darkest England and the Way Out, 1890, p.112ff.

336 Booth, William, In Darkest England and the Way Out, 1890, p.109
} 
to the city colony food depots or be sold on the regular market in town ${ }^{337}$.

The most important and promising aspect of the farm colonies in Booth's eyes constituted their educational opportunities. With the farm colonies, he anticipated, would be created "great schools of agricultural education", a veritable "Working Man's Agricultural University"338. The onset of industrialisation, Booth felt, had largely eradicated knowledge of the land and how to extract a living from it which had for centuries been handed down from father to son; within less than a hundred years, specialised industrial skills had replaced agricultural know-how. But Booth pointed out that the new qualifications proved useful only as long as one could find employment in one's acquired trade. This state of dependency on the capital and business plan of others had, in his eyes, to be remedied if the problem of pauperism were ever to be solved. He hoped that the communal farms would re-train the urban poor in agricultural skills; they represented "a place where those indispensable practical lessons are given which will enable the Colonists to know their way about and to feel themselves at home wherever there is land to till, stock to rear and harvest to reap" ${ }^{339}$. With his proposals, Booth of course voiced cutting criticism of the modern form of industrialised economic organisation.

Like the city colony, the farm colony, too, was in Booth's scheme of social improvement but a transitional stage on the road towards self-dependency for the individual. Booth envisioned agricultural settlements springing up around the original site of the farm colony which could house those who had graduated from the colony ${ }^{340}$. Eventually, he hoped, he would be able to group the ex-colonists together as partners in a co-operative farm running along the lines of E. T. Craig's farming commune at Ralahine in Ireland which Booth described in some detail ${ }^{341}$. The commune which ran for about eighteen months in 1831 and 1832 and comprised about eighty people farmed an estate leased at a fixed rent payable to the owner in farm produce. All profits belonged to the members; they were paid out in the form of labour notes which could be exchanged for goods at the community's cooperative store. The estate was managed by a committee which decided on the use of the land, allotted to each member their daily chores and was responsible for upholding order upon the farm. "Everything was prosperous", Booth informed the reader, "and the members of the association were not only benefited themselves, but their improvement exercised a beneficent influence upon the people in their neighbourhood." ${ }^{342}$ Booth put so much faith in cooperative farming along the lines of the Ralahine experiment as to contend that should such communes be

\footnotetext{
337 Booth, William, In Darkest England and the Way Out, 1890, p.132

338 Booth, William, In Darkest England and the Way Out, 1890, p.138

339 Booth, William, In Darkest England and the Way Out, 1890, p.134

340 Booth, William, In Darkest England and the Way Out, 1890, p.141

341 Booth, William, In Darkest England and the Way Out, 1890, p.142

${ }^{342}$ Booth, William, In Darkest England and the Way Out, 1890, Appendix, p. XXIV
} 
established in England, the problem of unemployment and of food supply could be regarded as „unquestionably solved“6343.

Despite the many unused stretches of land, however, Booth did not expect to accommodate all of the surplus unemployed on British land. He proposed to establish overseas colonies as the third and final part of his grand scheme for social amelioration. Booth made it clear that he did not wish to deport the pauper, but intended to help to emigrate those who hoped for a fresh start. He proposed to acquire large sections of land in some part of the Empire favourable to farming, for instance in South Africa or Western Australia, and to settle emigrants there in a community similar to the farm colonies from which they had emerged back home. In Booth's plan, the overseas colonies would form part of England in more than just personal perception: they would be governed along the lines of the laws of England and maintain strong links with the mother country as the principal market for their surplus farming produce: "The ship which takes out emigrants will bring back the produce of the farms, and constant travelling to and fro will lead more than ever to the feeling that we and our ocean-sundered brethren are members of one family." ${ }^{344}$

Booth cautioned that only sufficiently trained and tested men and women be sent abroad. He believed that graduates of the farm colonies would have picked up adequate agricultural skills and a basic knowledge of how to build their own houses, drain the land and build roads. More important than factual knowledge in Booth's eyes, however, was the moral education of emigrants' hearts and minds. Settlers, he believed, would have to be educated "in those habits of patience, forbearance and affection which would so largely tend to their own welfare, and to the successful carrying out of this part of our scheme" ${ }^{, 45}$. Even more so than the farm colonies at home the overseas settlements depended upon the willingness of every single participant to co-operate in setting up an operative social, economic and political community. If prudently carried out, Booth assured his readers, the above suggestion would in the process of time effect the transfer of the entire surplus population of Britain to the advantage not only of Britain herself, but also of the individual emigrants and the receiving countries ${ }^{346}$.

Booth believed that the entire scheme proposed in In Darkest England could work only if governed with the strictest of discipline among all participants. For those who had been out of work for years, he acknowledged, it could be hard to adapt to the regularity and exertion of a life of toil. He was prepared to give "a little patience and coaxing (...) to get them in the way of it" exciting and satisfying labour on a farm which had nothing in common with the stupefying toil in a

\footnotetext{
343 Booth, William, In Darkest England and the Way Out, 1890, p.142

344 Booth, William, In Darkest England and the Way Out, 1890, p.152

345 Booth, William, In Darkest England and the Way Out, 1890, p.147

346 Booth, William, In Darkest England and the Way Out, 1890, p.148

347 Booth, William, In Darkest England and the Way Out, 1890, p.261
} 
city factory, he believed, would help to motivate his clients. But chiefly, Booth hoped to regulate his clients by restoring to them a sense of worth and dignity by treating them as human beings rather than as cases or inmates. "The chief reliance for the maintenance of order", Booth placed on a "spirit of love which will prevail throughout the community" 348 and which would distinguish Booth's scheme with all due finality from the machinations of the Poor Law.

In 1902, the Salvation Army purchased a piece of land of 3200 acres in Hadleigh, Essex, to set up a pioneer farm colony. Here, Salvationists cultivated the land and ran a successful brick work. The farm acquired model standing of international dimensions. Beatrice Webb and her co-deviationists on the Poor Law Commission of 1909 visited the estate and found themselves very impressed by it. Possibly as a consequence of this visit, the Minority Report for the Poor Law Commission recommended governmental co-operation with relief and rescue schemes run by independent religious agencies ${ }^{349}$. The American social activist and novelist Rider Haggard reviewed Hadleigh Farm in an enthusiastic report for the English and American governments published in 1910 under the title Regeneration ${ }^{350}$.

Hadleigh Farm still exists as a semi-commercial enterprise in organic farming.

\section{The Individual as Focal Point of Booth's Social Thought}

With In Darkest England and the Way Out Booth did not offer a system of comprehensive social reconstruction. He recognised the emotional appeal of drawing up a social utopia, or finding "shortcuts to the Millenium" 351 as he called it; yet he did not delude himself about such plans for a perfectly harmonious and just society being current coin. Booth concerned himself with the here and now, in his work as a Christian evangelist as well as in his writings as a social reformer. "I am a practical man", he admitted, "dealing with the actualities of to-day. [...] I am quite prepared to hail with open arms any Utopia that is offered to me. But it must be within the range of my fingertips." ${ }^{352}$ To him, for any measure of social reform to be successful, the remedy proposed had to provide permanent relief, and be immediately applicable ${ }^{353}$.

\footnotetext{
348 Booth, William, In Darkest England and the Way Out, 1890, p.138

349 Walker, Pamela J., Pulling the devil's kingdom down: the Salvation Army in Victorian Britain, 2001, p.241

${ }^{350}$ Haggard, H. Rider, Regeneration being an account of the social work of the Salvation Army in Great Britain, 1910

351 Booth, William, In Darkest England and the Way Out, 1890, p.79ff.

352 Booth, William, In Darkest England and the Way Out, 1890, p.79

353 Booth, William, In Darkest England and the Way Out, 1890, p.84
} 
Booth's practical, hands-on approach to social reform made his scheme compatible with many schools of thought except, he emphasised, that of the anti-Christian laissez-faire economist who believed in the doctrine of the survival of the fittest, and the Marxist revolutionary who wished for as many discontented people as possible as motors of an imminent coup d'etat. ${ }^{354} \mathrm{E}$. P. Thompson has argued, for instance, that in the last decades before the end of the century, Salvationism ran in "double harness with London Radicalism"355. The historian Victor Bailey has found interesting parallels in method, clientèle and programmatic aims between Salvationism and socialism during the same period. Both movements, Bailey wrote, drew on and invigorated an emerging working class consciousness; both joined forces, for example, during the London Dock Strike in $1889^{356}$. Although politically Booth remained a conservative, he worked side by side with bodies like trade unions or the Fabian Society. In an interview with W. T. Stead for the War Cry in 1908 Booth declared himself "a Socialist, a Salvation Socialist"357. At the same time, the non-revolutionary, ameliorist social programme of the deeply religious Salvation Army, and Booth's insistence that while helping one class, social work may not seriously interfere with the interests of another ${ }^{358}$, continued to attract donations and support from social and political conservatives.

The key to an understanding of Booth's social scheme lies in his focus on the individual. It was from the point of view of the single person that he attacked and tried to solve the problems of industrialised modern society. His unusual perception of and overriding concern for the individual fate behind the mass of poverty comes out most clearly in the parts of his book, in which Booth spoke about those who in Victorian eyes made up the bulk of the undeserving poor. He took up the cudgels for prostitutes, attributing their "fall" to economic pressures, naiveté, rape or simply lack of an alternative, and proposed to open homes for these girls in order to give them a perspective other than the demimonde of prostitution. He planned to gather ex-prisoners in special homes for training and re-adjustment to independent lives. He showed unusual compassion for the drunkard, recognising drunkenness as an illness, "often inherited, always developed by indulgence, but as clearly a disease as ophthalmia or stones" ${ }^{\prime 359}$. Those afflicted with a pathological craving for drink ought to be met with sympathy and understanding, and be cured rather than accursed, he believed. Booth proposed to establish hospitals to guide them through their period of withdrawal and set them up for a return to a normal, industrious life. ${ }^{360}$ For Booth, social reform had to aim at helping the

\footnotetext{
354 Booth, William, In Darkest England and the Way Out, 1890, p.18 and p.143

355 As quoted in Bailey, Victor, In Darkest England and the Way Out, 1984, p.135

356 Bailey, Victor, In Darkest England and the Way Out, 1984

357 Woodall, Ann M., What price the poor?, 2005, p.181

358 Booth, William, In Darkest England and the Way Out, 1890, p.84

359 Booth, William, In Darkest England and the Way Out, 1890, p.48

360 Booth, William, In Darkest England and the Way Out, 1890, p.187
} 
person in need and the supreme test of any such scheme for him lay in the answer to the question: „What does it make of the individual?" 361

Booth's design rested upon a balanced attribution of guilt and responsibility for solving the social question to society and the individual. He detected a straightforward interrelation between the community as a whole and its members: "What is bad for one must be bad for both, what is beneficial for one must be beneficial for both." ${ }^{362}$ In Booth's eyes, society was to blame to a high degree for the existence of the submerged tenth. Many of the poor had never had a chance of doing better, Booth stated: they had been born into a poisoned atmosphere, educated in circumstances which had rendered modesty an impossibility, and been thrown into life in conditions which made vice a second nature ${ }^{363}$. The community needed to lay stepping stones across the bog which separated the destitute from a life in respectable society, if only on the low ground of self-interest, lest their neglect become a danger to its well-being and security.

Yet, despite society's failings, Booth held that the responsibility for rising from the abyss rested ultimately with the individual. He lamented that many modern schemes of reform forgot that it took „,a soul to move a body, e'en to a cleaner sty ${ }^{6364}$. With fully fifty percent of the poor, he claimed, their own evil conduct was the cause of their destitution ${ }^{365}$. To get a man soundly restored, he wrote, it was thus not enough to equip him with new clothes, some bread and a place to sleep; one had to aim at a person's heart and character if one hoped to achieve any lasting good. Material help from without was useful only in so far as it developed moral strength within. So it was with Booth's own scheme as laid out in In Darkest England: "our success will depend upon the extent to which we are able to establish and maintain in the minds of the workers sound moral sentiments" ${ }^{\prime 36}$, he cautioned his readers.

Booth's central concern in social reform was to restore to the poor their humanity. His main criticism of social work as customarily undertaken attacked its de-humanising aspects: mere charity, he claimed, ignored a person's moral and emotional state. The Charity Organisation Society symptomatically described its beneficiaries as "cases". Nor did the casual ward or the workhouse take into account a person's emotional and psychological circumstances; Booth described their administrations as "mechanical, perfunctory and formal". The poor who sought refuge in the casual wards were treated simply as units, "no more thought of or cared for than if they were so many

\footnotetext{
361 Booth, William, In Darkest England and the Way Out, 1890, p.84

${ }^{362}$ Booth, William, The Salvation Army and Poor Law Reform, 1909, p.63

363 Booth, William, In Darkest England and the Way Out, 1890, p.86

364 Booth, William, In Darkest England and the Way Out, 1890, p.45

365 Booth, William, In Darkest England and the Way Out, 1890, p.252

366 Booth, William, In Darkest England and the Way Out, 1890, p.110
} 
coffee beans passing through a coffee mill"367. Charity of the traditional perfunctory type crushed the manhood out of the man until one had on one's hands "a reckless, despairing, spirit-broken creature, with not even an aspiration to rise above his miserable circumstances, covered with vermin and filth, sinking ever lower and lower"368. Calling upon his extensive experience with slum work as undertaken by the Salvation Army, Booth asserted that ameliorative work which dehumanised the individual, whether run by private agencies or state-operated, would not only invariably fail, but make matters worse.

As a general guideline to social work, Booth issued his famous Cab Horse Charter to his contemporaries. He denounced the present state of society where prisoners enjoyed a higher standard of living, more nutritious food and better sanitary conditions, than large sections of the working classes. Men were, in fact, often treated worse than the ordinary work horse in London. If a horse fell in the streets, Booth contended, it was helped up without someone asking whether it may have stumbled through its own fault. Every cab horse in London had three things: food, shelter and work, which was more than could be said about large parts of the working class population. It was the standard Booth set for his own undertaking. "These are the two points of the Cab Horse Charter. When he is down he is helped up and while he lives he has food, shelter and work." ${ }^{669}$ Booth sought to apply the principles to the poor he proposed to help. He made help conditional not on means tests or a test of character as did, for example, the Charity Organisation Society, but on the individual's neediness and on their earnest desire to do better for themselves and their dependants ${ }^{370}$. He believed that the enormous success of Salvation Army work with men and women from the very lowest sections of society proved him right in his approach.

Booth operated upon the assumption that, above all, one needed to instil in the poor a sense of hope and direction which would help motivate the individual to fight his or her way out of the squalor and destitution of slum life: "if he be so deep down in vice and has been there so long that he has lost all heart and hope, and power to help himself", Booth stated, "he must be inspired with hope and have created within him the ambition to rise." ${ }^{371}$ Booth believed that the first precondition of successful social work was to develop self-respect in the man and the woman - or in the words of the Cab Horse Charter: to help them up. The easiest way to do so was to give them work, and Booth's three-tier scheme set out to provide them with it: "To begin with", Booth lauded his own plan, "it finds work for the unemployed. This is the chief need. (...) No matter what other helps are

\footnotetext{
367 Booth, William, In Darkest England and the Way Out, 1890, p.72

368 Booth, William, In Darkest England and the Way Out, 1890, p.106

369 Booth, William, In Darkest England and the Way Out, 1890, p.20

370 Booth, William, In Darkest England and the Way Out, 1890, p.131

371 Booth, William, In Darkest England and the Way Out, 1890, p.85
} 
discovered, without work there is no real ground for hope." ${ }^{372}$ In addition, the labour colonies in town and countryside offered a strong element of personal edification with prayer meetings, social gatherings and individual counselling in times of trouble. Booth also proposed to institute a poor man's lawyer in destitute neighbourhoods which could act not only as legal representative, but as a confidante to the poor in difficult times ${ }^{373}$.

Booth believed that almost everybody could, if treated with dignity and helped with regard to his or her personal circumstances, eventually be turned into useful, dutiful and obedient citizens of the English nation. The inhabitants of outcast London, he challenged his contemporaries, could surely not be much more unfavourable subjects for reform and redemption than were the savages and heathens in distant countries in whose conversion Christians believed. Booth detected enormous potential lying latent in provincial tap-rooms and city gin palaces which had only to be awakened and applied to the benefit of the entire social community: "some of the brightest men in London, with some of the smartest pairs of hands, and the cleverest brains, are at the present moment weltering helplessly in the sludge from which we propose to rescue them." ${ }^{\prime 374}$ His positive view of human nature in general, and the nature of the average pauper in particular, set Booth apart from other social reformers at the time of his writing.

Booth admitted that after everything has been done to help the poor to raise themselves from the gutter, there would remain a residuum of the unhelpable, the moral lunatics. From heredity, custom or hopeless demoralisation, these would have passed the point of return to respectable society. Booth suggested to seclude them permanently in institutions not unlike the farm colonies in order to avoid cross-contamination with those who had a chance of being saved. He was not prepared, however, to give up on them, just as he was not willing, as an evangelist and general of the Salvation Army, to give up on their souls. "Not until the breath leaves their bodies", he admonished his co-social workers, "should we cease to labour and wrestle for their salvation.",375

Booth, William, In Darkest England and the Way Out, 1890, p.253

${ }^{373}$ Booth, William, In Darkest England and the Way Out, 1890, p.216

${ }^{374}$ Booth, William, In Darkest England and the Way Out, 1890, p.128

375 Booth, William, In Darkest England and the Way Out, 1890, p.204f 


\section{Back to the Land}

a) A Critique of Modern Industrialised Society

With In Darkest England and the Way Out Booth placed himself among those who sought a return to pre-industrial, rural forms of living as the most effective solution to the social problem. His text contained a critique of modern industrialised society which took up most of the core arguments put forward by supporters of the back to the land movement. Modern forms of living, Booth contended, damaged men's health, physical, mental and moral, and counteracted their chances of salvation in the literal sense of the word. With regard to morality and social harmony, Booth specified, urbanisation had destroyed the natural set-up of society and disrupted healthy social intercourse between individuals as well as between the classes. He argued that the drift to the cities forced the multitudes to dwell in conditions which sapped them of bodily strength and mental vigour; the modern organisation of work in an industrialised economy reinforced the detrimental effects of urbanisation by disrupting the family and leaving the individual estranged from his or her Godgiven, natural habitat, the land.

Booth believed that urbanisation made people ill. The destitute neighbourhoods of Darkest England, like Darkest Africa, reeked with malaria. Booth wrote: "The foul and tepid breath of our slums is almost as poisonous as that of the African swamps." 376 Overcrowding constituted part of the problem, so did the unsolved issue of the London sewage system which "feculant and festering, swings heavily up and down the basin of the Thames with the ebb and flow of the tide" 377 . Booth found the streets of East London flooded with litter and detritus, as dirty and neglected as its inhabitants. He described with some horror how the buildings in such areas stood so close that no sunlight reached the ground, nor could fresh winds air the foul-smelling and disease-ridden streets. No grass, trees or flowers brightened up the atmosphere of the neighbourhoods. Such surroundings, Booth asserted, proved positively detrimental to a person's physical and emotional state.

In Booth's eyes, the slums of industrial areas constituted the "great Slough of Despond of our time" ${ }^{378}$, worse even than Dante's Inferno and the cruelties of its torture chamber. Most alarming in his opinion were the effects of such conditions on the children born into and growing up in these destitute surroundings. The overcrowded homes of the poor compelled the young to witness everything: sickness, deaths and births, sexual intercourse, physical and verbal abuse. No wonder,

\footnotetext{
376 Booth, William, In Darkest England and the Way Out, 1890, p.14

377 Booth, William, In Darkest England and the Way Out, 1890, p.23

378 Booth, William, In Darkest England and the Way Out, 1890, p.13
} 
Booth stated, that they so often did not develop a sense of righteousness and morality. Booth believed that the fighting gangs of half-grown lads in Lisson Grove and the Scuttlers of Manchester, harbingers of modern youth gangs which terrorised and scandalised Victorian society, represented the ugly symptoms of a social situation which left large sections of the population to fight for themselves in the most abject conditions. He warned that the problem was one which concerned the entire nation and would only grow in urgency. "Children thus hungered, thus housed and thus left to grow up as best they can" without moral guidance and without hope for a better future, he pointed out, "are not, educate them as you will, exactly the most promising material for the making of the future citizens and rulers of the Empire." 379

But not only the nation's health, physical as well as moral, was at stake. The rural exodus threatened the very set-up and political stability of society. With the onset of urbanisation, the cities had expanded beyond the confines of manageability. "Our troubles in large towns", Booth analysed, "arise chiefly from the fact that the massing of population has caused the physical bulk of society to outgrow its intelligence." ${ }^{380}$ In the compact social unit of the rural village, Booth argued, the community was alert to the needs and special circumstances of each and all, and help was close at hand; there, the honour of a family represented enough of a security for small sums to be forwarded or jobs offered ${ }^{381}$. In the towns, the social body appeared to have grown new limbs not attached to its brain. In the slums of the great industrial centres, Booth criticized, men had ceased to be neighbourly and lived as a congested mass of population without any human ties connecting them and no communal intelligence directing their co-habitation. Multitudes of men and women found themselves deprived of the knowledge and intelligence of their social betters, he held. In a city neighbourhood, those troubled in mind or body often had no one to talk to about their difficulties and to ask for advice. Here, a man could die within a few doors of those who, had they known about his situation, could have helped and healed.

Booth felt most alarmed about the threat posed by modern life to the nuclear family. Industrial employment took the parents away from their homes for the major part of the day ${ }^{382}$. A London omnibus driver who worked for up to sixteen hours a day, Booth explained, was, through the sheer force of circumstances, unavailable to his children as a father. Nor could the mothers who had had to exchange homework in their rural cottages for a day-long job in a city factory care for the children. Booth feared the loss of natural affections within the nuclear family and with it, a steep decline in morality, sympathy and community spirit among the younger generation. The modern

\footnotetext{
379 Booth, William, In Darkest England and the Way Out, 1890, p.66

380 Booth, William, In Darkest England and the Way Out, 1890, p.115

381 Booth, William, In Darkest England and the Way Out, 1890, p.212

382 Booth, William, In Darkest England and the Way Out, 1890, p.64ff.
} 
form of work organisation also prevented children from learning in the traditional way skills and know-how suitable for their sexes and their future roles in the family. Booth lamented that too many girls nowadays went to work in the factories as soon as they left school without any knowledge of how to cook, do the laundry, rear the children and be good wives. In modern society, Booth postulated, provisions would have to be made for teaching the young their natural skills and instilling them with a sense of love and communal spirit in order to halt the demise of the family ideal.

Booth also pointed to the de-humanising effects of industrialised work. The present rage for machinery, he explained, had almost totally supplanted hand labour ${ }^{383}$. He detected a "rush from the human to the machine" which had left the individual deprived of a sense of the value of his or her personal labour. Handling soulless machines, Booth believed, was extremely demoralising for the workman who had previously entertained considerable pride in his manual skills and derived much of his personal worth from his trade. The general thus blamed industrialisation for much of the destitution to be found in the East End of London and similar neighbourhoods in industrial centres around England, not only by leaving multitudes without a job, but by robbing them of the selfrespect, hope and sense of perspective which in Booth's eyes were the first essential for a healthy, happy and respectable life.

Considering the detrimental effects of slum housing and the demoralising force of modern work, it took Booth no wonder that after leaving generation after generation to grow up underfed, dis-homed and uneducated, there should develop "a heredity of incapacity, and thousands of dull-witted people should be born into the world, disinherited before their birth of their share of the average intelligence of mankind"384. Modernity, Booth believed, enslaved the individual. Like Arab raiders in Darkest Africa, English capitalists exploited the inhabitants of destitute neighbourhoods. Too many laboured under conditions, in dangerous trades, without insurance against life's contingencies and without the prospect of some kind of pension in old age, which left them totally devoid of personal rights and dignity ${ }^{385}$. The conditions in the slums and factories excluded large sections of the population from the "universal birthright of liberty"386. They lived in a prison made up of exploitation, poor health, drink and crime from which death seemed the only deliverer. England, he admonished his country, had freed her "negroes" sixty years ago - it was high time to also liberate her white slaves ${ }^{387}$.

\footnotetext{
383 Booth, William, In Darkest England and the Way Out, 1890, p.273

384 Booth, William, In Darkest England and the Way Out, 1890, p.44

385 Booth, William, In Darkest England and the Way Out, 1890, p.13

386 Booth, William, In Darkest England and the Way Out, 1890, p.205

387 Booth, William, In Darkest England and the Way Out, 1890, p.23f
} 


\section{b) The Ideal of The Pre-Industrial Social Community}

God, Booth said, had wisely and mercifully placed men in families, be it their immediate relations or the larger family of the village community where they could find others, wiser and more experienced than themselves to help them in times of trouble. The family idea appeared to Booth the most promising basis for a new social organisation. Like Headlam he drew on the idea of the Fatherhood of God to argue the brotherhood of men. "'Our Father' is the keynote", he wrote. "One is the Father, then all we are brethren." ${ }^{388}$ As brothers and sisters, all were responsible for the wellbeing of the weaker members of the family, catering for their bodies as well as their hearts. Society, Booth asserted, needed "a great deal of mothering". It was the ideal the Salvation Army had set out to attain. "We cannot know better than God Almighty what will do good to men. We are content to follow on His lines" ${ }^{\prime 39}$ and to restore something of the family ideal to the many thousands who had no one to turn to in times of trouble.

By re-settling the urban poor in rural communities upon the land, first in farm colonies and later in small-holding schemes or cooperative farms, Booth hoped to restore to them the social network of which urbanisation had robbed them. With his plan of farm colonies and co-operatives, he believed to have found a solution to the social problem which was both practical and immediately implementable and would fend off what Booth perceived as the worst excesses of modern civilisation. With his scheme, Booth hoped to house the slum dwellers in surroundings fit for human habitation. He aimed at providing them all, adults as well as children, with an education suitable to their needs. He offered work to those capable of doing any; and above all, sought to restore to society a sense of brotherhood, mutual responsibility and civic duty which the unmanageable units of city neighbourhoods had largely destroyed. Booth believed in the "myth of the rural village" 390 , an idealised version of truly communal, healthy and harmonious life in the English hamlet ${ }^{391}$. The country epitomised all that Booth found lacking in the slum districts of industrial centres: fresh air, good sanitary conditions, sufficient food, trees and pastures, friendly relations between the working classes and their social superiors, and most importantly, direct experience of God's nature and a return to the land in the form of private gardens. In such an environment, Booth believed with many of his contemporaries, there would spring up almost automatically vigorous labourers, morally sound Christians and dutiful citizens of the British empire.

The countryside, Booth envisioned, would return to the enslaved and demoralised working man and

\footnotetext{
388 Booth, William, In Darkest England and the Way Out, 1890, p.219

389 Booth, William, In Darkest England and the Way Out, 1890, p.219

390 Meacham, Standish, Regaining paradise. Englishness and the early garden city movement, 1999, p.8

391 Booth, William, In Darkest England and the Way Out, 1890, p.62
} 
woman those elements of dignity and humanity which Booth considered essential for effective social work. All the above could be achieved at very low cost with the establishment of farm colonies in England and abroad along the lines of his scheme as outlined in In Darkest England and the Way Out. Booth defended his plan against objections that the poor were not fit to partake in his grand design. Contact with the land, their original and natural habitat, he believed, would set free self healing powers in the destitute: "Take a man or a woman out into the fresh air, give them proper exercise and substantial food. Supply them with a comfortable home, cheerful companions, and a fair prospect of reaching a position of independence in this or some other land, and a complete renewal of health and careful increase of vigour will, we expect, be one of the first great benefits that will ensue." ${ }^{392}$ Booth also supported the idea of model suburban villages for industrial city workers. Despite his critique of urbanisation, he was realistic enough to accept city life as a modern reality and thus set out to adapt his family ideal, the vision of mutual guidance and support, to the needs of urban neighbourhoods. He envisioned suburban communities for up to 2000 families providing tenements of three or four rooms with private gardens or vegetable patches at a distance of about twelve miles from the town ${ }^{393}$.

For those whom circumstances forced to remain in the crowded districts of the cities, Booth sought to create a "new nervous system for the body politic" 394 to ensure swift and almost automatic communication between the community and its most needy member. With facilities suggested in his grand design such as the labour bureau or the poor man's lawyer ${ }^{395}$ he hoped to restore to the city and the nation as a whole the sense of community which had, in Booth's understanding, prevailed in the pre-industrial village. No artificially installed institution, he conceded, could ever replace the personal bond of friendship. Yet, he planned to permeate the whole of society with "brotherly associations established for the purpose of mutual help and sympathising counsel" 396 in an attempt to guard against the worst excesses of modern civilisation.

Lastly, Booth hoped that the countryside would also offer opportunities for re-organising the economy which the large production units of industrial cities could not provide. In his colonies, Booth proposed to return man to the workbench and restore some of the domestic occupations which steam had largely confined to the factories ${ }^{397}$. We have already seen that Booth favoured the establishment of communal farms along the lines of the Ralahine experiment. He also hoped to

\footnotetext{
392 Booth, William, In Darkest England and the Way Out, 1890, p.264

393 Booth, William, In Darkest England and the Way Out, 1890, p.210ff; the ideal of the Garden Suburb will be examined at greater detail in the next chapter of this thesis.

394 Booth, William, In Darkest England and the Way Out, 1890, p.116

395 Booth, William, In Darkest England and the Way Out, 1890, p.217

396 Booth, William, In Darkest England and the Way Out, 1890, p.217

397 Booth, William, In Darkest England and the Way Out, 1890, p.139
} 
institute village workshops and small-scale industry which would operate along cooperative lines. Booth detected in the principle of cooperation a „key of the solution of the Social Problem” ${ }^{398}$.

Successful cooperation, he believed, took on the form of an applied association for purposes of distribution as well as production. Hitherto, much emphasis had been placed on the distribution angle of cooperative societies and the results obtained gave some credit to the approach. Yet, Booth reasoned, the real problem of industrialised society was the congestion of capital in the hands of too few producers, and the social question would never satisfactorily be solved until every labourer became his own capitalist moving into the role of producer himself. There was no need, Booth implied, for great schemes of state socialism: the whole idea of cooperation could be implemented simply, economically and speedily by uniting groups of workers into self-dependent cooperative units of production ${ }^{399}$.

However, Booth cautioned, the cooperative experiment would work only if the mistakes of past attempts were not repeated. For all his understanding for the situation of the destitute and for all his respect for their dignity and humanity, Booth did not believe in democracy, neither on the microlevel of business matters nor on the macro-level of national politics. He believed that previous endeavours at cooperatives had often failed because, being based on the principles of equality and government by vote of the majority, the participants had sooner or later come to loggerheads over some issue of management and the whole enterprise had fallen to pieces over a clash of opinion. Yet, management signified government and government implied authority, to be executed, in Booth's eyes, by a single representative of the group equipped with powers of decision and freedom of action to match the like powers of the free capitalist. He argued that in cooperative enterprises one had to add the principle of subordination to the principle of consent. To the principle of consent, one had to super-add the principle of "subordination". Booth's farm colonies thus accepted only those who willing to submit to discipline and authority.

From his experience with the Salvation Army, Booth concluded that the people did not as a rule object to being governed. Only when stupidity and incapacity took possession of the seat of power did insurrections break out. The general reported how, at the foundation of the Salvation Army, he had been "constantly warned against the evils which this autocratic system would entail". In a democratic age, his critics had pointed out, the people would never stand the establishment of his spiritual despotism. And yet, possibly even because of the discipline imposed upon its rank and file, Booth speculated, the Salvation Army had grown "from year to year with a rapidity to which nothing in modern Christendom affords any parallel." ${ }^{400}$ Under the wise government and judicious

\footnotetext{
398 Booth, William, In Darkest England and the Way Out, 1890, p.229

399 Booth, William, In Darkest England and the Way Out, 1890, p.231

${ }^{400}$ Booth, William, In Darkest England and the Way Out, 1890, p.243
} 
rule of a capable leader, Booth believed that the organisation of even the most disorganised, drinksodden, hopeless and sweated denizens of Darkest England could be achieved.

\section{Education: An Essential in Social Reform}

Any scheme of social regeneration to be successful in the long run, however, Booth believed, had to be accompanied by a reform of the nation's educational system. He hailed education as a possible "panacea" for the social question, but only as long as it aimed not at mere schooling, but at the development in the person of all his or her latent faculties and capacity for self-improvement ${ }^{401}$. Booth abhorred the present system of compulsory elementary schooling. He found it "unnatural and shamefully wasteful of the energies of the children" 402 . If anything, he argued, it aggravated the problem by mixing children from decent homes with those from destitute families and helping along cross-contamination between them. It had been compulsory education as prescribed by the Forster Act, Booth pointed out, which had brought about the Scuttlers who roamed the streets of Manchester and the fighting youths in the West of London. ${ }^{403}$.

The present system of education tended to overstock the labour market with over-qualified personnel leaving depleted the reservoir for sturdy, manual work. Focusing on purely intellectual skills like reading, writing and mathematics, it ignored a child's emotional and moral education and neglected to develop his or her manual skills. Such areas of education, Booth believed, had become particularly pressing needs since factory work and long hours away from home had eliminated the parents as teachers of natural affection and moral behaviour. Booth considered it grotesque to call for universal education as delivered in the existing elementary schools when the basic needs of the children for food, clothing, a decent home, love and moral guidance were not taken care of. He foresaw immense advantages for the children - as for their parents - from moving them out of the unhealthy city neighbourhoods into the countryside. "To rear healthy children", he proclaimed, "you want first a home; secondly, milk; thirdly, fresh air; and fourthly, exercise under the green trees and blue sky." ${ }^{404}$ Country children possessed all of the above. Besides, they came into natural contact with life at the hall, the vicarage and the farm, and would thereby learn, almost

\footnotetext{
401 Booth, William, In Darkest England and the Way Out, 1890, p.77

402 Booth, William, In Darkest England and the Way Out, 1890, p.202

${ }_{403}$ Booth, William, In Darkest England and the Way Out, 1890, p.77

${ }^{404}$ Booth, William, In Darkest England and the Way Out, 1890, p.62
} 
automatically, basic social skills and be shown their station in life.

Booth proposed to replace the present system of education by industrial schools, where students would be taught intellectual material for half the morning and manual skills for the other half. In addition, he recommended teaching domestic skills for girls and industrial training for boys. By this method of teaching, Booth expected healthy and happy children who could care for themselves at considerably less cost to the state and municipalities. "I am nearly satisfied in my own mind", Booth proclaimed, "that the children of the streets taken, say at eight years of age, and kept till, say twenty-one, would, by judicious management and the utilisation of their strength and capacity, amply supply all their own wants, and would, I think, be likely to turn out thoroughly good and capable members of the community." ${ }^{405}$ Here again, Booth shows his firm belief in the reformability of almost every individual, how lowly and unpromising he or she may ever appear.

\section{Voluntarism or State Responsibility?}

In In Darkest England and the Way Out, Booth asked for the Salvation Army to be commissioned with implementing the scheme of labour colonies by which he hoped to solve the social question. The Army, he said, had ready to hand an organisation of volunteers "numerous enough and zealous enough to grapple with the enormous undertaking" ${ }^{\circ 06}$. It had already proven successful in its work with men and women from the lowest classes and could show an impressive record of individuals saved from misery and squalor. Last, the Salvation Army as an organisation aimed higher than did the average relief agency: its ultimate goal was a person's soul, and it thus went beyond bodily wellbeing towards a reformation of character, which Booth argued was the real target of social reform. In its work, the Salvation Army felt sure of the co-working powers of God: "We go not forth in our own strength to this battle, our dependence is upon Him who can influence the heart of men." ${ }^{407}$ In certain respects, Booth exemplified the "nonconformist conscience" of the late-Victorian period which, among other things, called for re-invigorated voluntary efforts in the sphere of poor relief and social reform. Booth encouraged his contemporaries to "come out and follow Him in this New Crusade" 408 , in the form of both, financial contributions as well as voluntary work in the slums and

\footnotetext{
405 Booth, William, In Darkest England and the Way Out, 1890, p.202

406 Booth, William, In Darkest England and the Way Out, 1890, p.239f.

407 Booth, William, In Darkest England and the Way Out, 1890, p.241

408 Booth, William, In Darkest England and the Way Out, 1890, p.284
} 
the colonies envisaged by the scheme.

Some, Booth conceded, may not like Salvationism and object to its being entrusted with so important a task. Yet, in his three-tier scheme, Booth promised to focus primarily on the physical and emotional needs of the poor and to offer spiritual salvation almost as an aside. In the face of the sheer dimension of destitution in English slums, he asserted, religious differences should not play so decisive a part as to prevent help wherever and by whom ever it was advanced. In Darkest England was primarily about the poor and their misery, not about fine points of Christian dogma, he argued. Was it not "infinitely preferable“, he asked, „that [the poor] should speak the truth, and be virtuous and industrious and contented, even if they do pray to God, sing psalms, and go about with red jerseys, fanatically, as you call it, 'seeking for the millenium' - than that they should remain thieves or harlots, with no belief in God at all, a burden to the municipality, a curse to society and a danger to the state" ${ }^{409}$ ?

In 1890, Booth still had little to say about the role of the state in the great enterprise of poor relief. Ultimately, he believed, a scheme such as proposed in In Darkest England should most profitably be run by the government; yet, he considered such a proposal to be utterly unrealistic in the near future $^{410}$. For the present, he planned to enlist state support only for the legally tricky parts of the scheme, such as confining the morally debauched ${ }^{411}$. He also expected financial support from the government and municipalities until the scheme had become almost self-supporting. Booth anticipated the need for about one million pound sterling in order to set the scheme in motion and give it a fair chance at success. He called for voluntary contributions as well as for regular rates from the government. "Seeing that the country pays out something like Ten Million per annum in Poor Law and Charitable Relief without securing any real abatement of the evil", he argued, "I cannot doubt that the public will hasten to supply one-tenth of that sum (...) to give the present scheme a fair chance of getting into practical operation." ${ }^{912}$ Booth considered the sum required to be very modest when compared to the amount spent yearly by Britain on expeditions such as Stanley's and on military operations ${ }^{413}$. Britain's first concern, Booth implied, should not be the savage tribes of the African jungle, but the destitute inhabitants of Darkest England.

By the first decade of the twentieth century, however, newly introduced legislation had persuaded Booth that the state could be entrusted with a more active role in social reform. The degrading and de-humanising principle of Less Eligibility had finally given way to a more positive approach in state-run support systems, as the Unemployed Workmen Act of 1905 proved to Booth. Destitution,

\footnotetext{
409 Booth, William, In Darkest England and the Way Out, 1890, p.280

410 Booth, William, In Darkest England and the Way Out, 1890, p.267

411 Booth, William, In Darkest England and the Way Out, 1890, p.206

412 Booth, William, In Darkest England and the Way Out, 1890, p.246

413 Booth, William, In Darkest England and the Way Out, 1890, p.251
} 
he noted, was no longer the only qualification for state aid $^{414}$. In his evidence on the treatment of the unemployed given to the Royal Commission on the Poor Law and published as a pamphlet in 1909, Booth proposed to entrust the government with the management of detention colonies for vagrants, work shy and criminals, feeling confident that the state would operate them with the aim not of punishment, but of restoring the individual to efficiency and respectability. For the able-bodied unemployed unable to procure work, he recommended that the state and the municipalities offer remunerative relief work and take over the running on a national scale of labour bureaux of the kind presently established by the Salvation Army. He urged the state to "come in with a stronger hand than it ha[d] yet exerted, and say, 'This shall not be allowed to continue'"'415. In all social work, however, whether voluntary or state run, Booth believed it to be an essential precondition for success that the relieving agency act with true sympathy and the full recognition that society had an intellectual, an ethical and religious, as well as an economic work to do for all who sought its shelter and aid ${ }^{416}$.

In In Darkest England and the Way Out, Booth set out a plan for social reform which focused on the individual and his or her personal misery, physical as well as emotional. It was a focus which followed from the fact that in his social endeavours, Booth cared for the body mainly as a way of reaching and saving the souls of the poor. As first essential to successful rescue work, Booth proposed to restore to every person his humanity. This, he believed, was best done by providing him or her with the essentials for health and dignity such as a decent home, substantial food and, most importantly, work. He then challenged the recipients to fight their own way out of the misery of slum life.

Despite his emphasis on the individual, however, Booth did not absolve society from part of the responsibility for the present social situation. Modern civilisation, he believed, enslaved the individual. Urbanisation had locked up large sections of the population in physically and morally corrupting neighbourhoods. The modern industrialised form of work organisation left many without a job altogether and forced those in employment to spend the major part of the day away from home in unhealthy, gloomy and badly aired factories performing soulless tasks handling machinery. Booth thus defied society to help the individual by giving him or her a chance to return to the country, to find sustainable employment in healthy surroundings and by providing all with an education suited to their respective needs now and in the future. In his plan for poor relief, Booth relied on voluntary efforts and the work of religious, non-state agencies such as, of course, the Salvation Army.

\footnotetext{
414 Booth, William, The Salvation Army and Poor Law Reform, 1909, p.5f

415 Booth, William, The Salvation Army and Poor Law Reform, 1909, p.55

416 Booth, William, The Salvation Army and Poor Law Reform, 1909, p.64
} 
In the next chapter, I explore the thought of another reformer who shared many of the characteristics exhibited by Booth. Henrietta Barnett also valued the individual as a basic unit of social reform. She, too, sought the key to the social problem in a return to the countryside. By contrast to Booth, however, Barnett fully accepted industrialisation as a social and economic reality. With her garden suburb scheme, she aimed at combining the beneficial sides of a pre-industrialised rural form of living with the dictates of an industrialised economy. 


\section{B. Socialist Christians}

\section{Chapter 4 - Henrietta Barnett and the Redeeming Powers of Community}

\section{Biographical Data: Henrietta Barnett}

The first of the thinkers chosen for this study in the category of socialist Christians, men and women who were socialists as well as Christians but did not explicitly resort to their religious creed to justify their political stance, is Henrietta Octavia Rowland Barnett, wife of Canon Samuel Augustus Barnett and co-founder of the first university settlement Toynbee Hall.

Compared with the majority of Victorian middle-class women who lived a quiet life as "angels in the house", Henrietta had an unusual personal history. With the housing reformer Octavia Hill, Helen Bosanquet from the Charity Organisation Society and the Fabian Beatrice Webb, she was among the few women of her class to become a public figure and leave a discernible mark on social reform. Her life and work bear witness to the emerging movement of women's emancipation in late Victorian Britain. By contrast to the female reformers mentioned above, however, her contribution remained curiously unacknowledged until relatively recently. A recent study by Micky Watkins looks at Henrietta Barnett's first fifty years and her work at Whitechape ${ }^{417}$. Barnett received more or less cursory treatment in histories of her final project, Hampstead Garden Suburb. Two important appraisals of her work as the architect of the model settlement can be found in accounts of the enterprise by the historians Kathleen Slack and Brigid Grafton Green ${ }^{418}$. But other accounts of the project minimise the impact of her visions or ridicule her intentions ${ }^{419}$.

In a seminal article in 1994, the historian Seth Koven suggested that her virtual disappearance from

\footnotetext{
417 Watkins, Micky, Henrietta Barnett in Whitechapel, 2005

418 Slack, Kathleen M., Henrietta's dream: a chronicle of the Hampstead Garden Suburb 1905-1982, 1982; see also Grafton Green, Brigid, Hampstead Garden Suburb 1907-1977, 1977

419 e.g. Miller, Mervyn and A. Stuart Gray, Hampstead Garden Suburb, 1992; see also Eden, William Arthur, Hampstead Garden Suburb 1907-1957, 1957; see also Ikin, C. W. and Brigid Grafton Green, Hampstead Garden Suburb: dreams and realities, 1990; see also Creedon, Alison, A benevolent tyrant? The principles and practices of Henrietta Barnett (1851-1936), social reformer and founder of Hampstead Garden Suburb, 2002, p.233
} 
the history of social reform may be linked to her sex and to traditional gender assumptions ${ }^{420}$. Micky Watkins' research confirms that Henrietta depicted herself as a maternal friend to the poor of Whitechapel and thereby fulfilled Victorian gender expectations. At the centre of her social concern stood the under-aged, disadvantaged and dependent, those who in her eyes required „mothering“. She took a particular interest in Poor Law children and became a "respected architect of state policies" ${ }^{\prime 21}$ for their welfare. Her Children's Country Holiday Fund sponsored vacations in the country for pupils from metropolitan slums. With the formation of MABYS, the Metropolitan Association for Befriending Young Servants, she offered personal, motherly guidance to girls entering domestic employment. In her husband's parish of Whitechapel, she sought out and assisted fallen women, overtaxed mothers of large families and habitual drunkards.

But her "social maternalism" 422 , Seth Koven has argued, formed but one side of her character and social endeavour. As a young girl, Henrietta Barnett had decided on a life of spinsterhood in the service of the poor. Like Beatrice Webb two decades later who famously vacillated over her marriage to Sidney, she entered married life only hesitantly and only after she began to realise that marriage afforded to her opportunities in social reform difficult to attain for single women. She built up a partnership with her husband Samuel Barnett based upon the idea of complementarity and equality which contradicted the Victorian model of subservience and obedience thought proper in a wife.

In her book The Making of the Home $e^{423}$ she offered a lengthy exposition of her understanding of John Ruskin's gender models as laid down in his Sesame and Lilies ${ }^{424}$. Barnett agreed with Ruskin that women differed from men insofar as they had greater moral and emotional sensitivities. Their emotional superiority fitted them perfectly for a role as peacemakers, diplomats and mediators, as the social mortar in both family and society at large. But in Barnett's eyes, this difference between men and women positioned the two not in hierarchical relations, where the man's reason and intellect trumped the woman's sensitivity. She believed that their differing natures fitted them for a union of perfect complementarity ${ }^{425}$. Funnily, in the case of her own marriage, the Ruskinian model of gender roles appeared curiously reversed. A contemporary wrote of her union with Samuel: "Though there was nothing in the least flabby or sentimental about him, the Canon was almost feminine in his gentleness and tenderness, whereas the inflexible will of his wife is almost

\footnotetext{
${ }^{420}$ Koven, Seth, Henrietta Barnett (1851-1936). The (auto-)biography of a late Victorian marriage, 1994

421 Koven, Seth, Henrietta Barnett (1851-1936). The (auto-)biography of a late Victorian marriage, 1994, p.31

${ }^{422}$ Koven, Seth, Henrietta Barnett (1851-1936). The (auto-)biography of a late Victorian marriage, 1994, p.41

${ }^{423}$ Barnett, Henrietta Octavia Rowland, The Making of the Home. A reading-book of domestic economy, etc, 1885

424 Ruskin, John, Sesame and lilies, 1888

${ }^{425}$ Koven, Seth, Henrietta Barnett (1851-1936). The (auto-)biography of a late Victorian marriage, 1994, p.37
} 
suggestive of the stronger sex. The one seemed born to persuade, the other to command." ${ }^{426}$ Although largely ignored by histories of feminism, Barnett was an early advocate of women's rights. In one of her earlier articles under scrutiny in the present study, she openly attacked the long prejudice, inferior education, political and legal inferiority and injustice which had created a difference between the sexes. She demanded that the system of education for girls be radically altered in order to prepare them for a life of active citizenship. "If in the future", she demanded, "women are to take their proper places in the development of the race, men must find in them not merely comfort, but force, inspiration, the redoubling of moral and intellectual faculties." ${ }^{427}$

Born in 1851, Henrietta Rowland started social work under the tutelage of Octavia Hill at St. Mary's, Bryanston Square, in 1869. While involved with work for the Charity Organisation Society (COS), she met Canon Samuel Augustus Barnett, a founder member of the COS. The two were married in 1873. In the same year, they moved to St. Jude's, Whitechapel, a parish which the bishop of London described as the worst in his diocese, "inhabited mainly by a criminal population, and one which has (...) been much corrupted by doles" ${ }^{\prime 428}$. The poor streets of Whitechapel formed the field of action for Henrietta Barnett's social endeavours. As the vicar's wife, she gained access to the homes of the poor. Her early preaching of COS principles and her restrictive handing out of charity must initially have alienated and enraged many of her charges. But her experiences in the neighbourhood taught her to modify her principles and to take a more comprehensive, environmentalist approach to social reform. She learnt first-hand of the realities of a life in poverty and developed her admiration for the moral courage, solidarity, selflessness and mutual support among the working classes which she repeatedly voiced in her social writings.

In collaboration with her husband, Henrietta Barnett helped to develop the idea of university settlements. She hoped that by encouraging young privileged university graduates to live and work among the metropolitan poor she could help to bridge the gulf between the classes. She played a vital role in the foundation and early direction of Toynbee Hall, the first of many settlements to come, at Whitechapel. That her vision of partnership and complementarity impacted on her and her husband's work and that she left a distinctive mark also on their joint endeavours is evident from contemporary accounts. C. R. Ashbee, an early resident of Toynbee Hall, for instance, wrote of Henrietta's role and character: "Mrs. Barnett is [...] the Prior and the Prioress of this place - the worthy head. A fine, noble, bright-eyed, vigorous woman she appears; and one that will have her own way and not be sparing of her opinion." ${ }^{429}$ In 1894, after twenty years among the poor in

\footnotetext{
${ }^{426}$ Koven, Seth, Henrietta Barnett (1851-1936). The (auto-)biography of a late Victorian marriage, 1994, p.42

427 Barnett, Samuel Augustus and Henrietta Octavia Rowland Barnett, Practicable socialism, 1894, p.131

428 Creedon, Alison, A benevolent tyrant? The principles and practices of Henrietta Barnett (1851-1936), social reformer and founder of Hampstead Garden Suburb, 2002, p.239

429 Koven, Seth, Henrietta Barnett (1851-1936). The (auto-)biography of a late Victorian marriage, 1994, p.41
} 
Whitechapel, the Barnetts moved to Bristol and shortly afterwards, back to London, where Samuel Barnett became curate of Westminster. Samuel Barnett died in 1913. Henrietta Barnett remained active in their common cause of social reform. Her main project in later years became the building and extension of the garden suburb at Hampstead Heath in which she aimed to put into practice, as we shall see in the course of this chapter, many of her ideas on an ideal society. She died in 1936, twelve years after becoming Dame Henrietta Barnett, in her home at the periphery of Hampstead Garden Suburb.

\section{Barnett's Ideological Position: Between Individual Growth and National Wealth - Between Voluntarism and State Aid}

In the tangle of ideologies on social reform, Henrietta Barnett embodied a mixture of various approaches. Seth Koven has remarked that through her sheer longevity, Henrietta Barnett's life formed a "bridge between the moral certitudes and convictions of the late-Victorian urban gentry and the growing intellectual, political and cultural doubts that engulfed this class" ${ }^{\circ 30}$ around the First World War. Within the framework of the present thesis, too, Barnett's thought forms a bridgehead between the ideas of the Christian socialists Headlam and Booth and the thought of the more secular-minded reformers to be discussed in the following chapters. Like Stewart Headlam and William Booth, she acknowledged the sanctity of humanity, and considered the development of individual personality to be a sacred right and duty. She set out to alter conditions in order to free man to seek his highest self. ${ }^{431}$ In an early article written in 1884, Barnett defined social reform as "the removal of certain conditions in and around society which stand in the way of man's progress towards perfection" ${ }^{\prime 32}$.

Yet, while Headlam and, to an even greater extent, Booth saw social reform first and foremost as a means towards spiritual salvation, Barnett also recognised the importance of individual achievement and growth for the nation as a political and economic body. She considered individual character to be not only a valuable thing in itself, but also "the only firm foundation of a nation's greatness" ${ }^{433}$. For her, deficiency in national character meant deficiency in common wealth in more than one

\footnotetext{
430 Koven, Seth, Henrietta Barnett (1851-1936). The (auto-)biography of a late Victorian marriage, 1994 , p.31

431 Barnett, Samuel Augustus and Henrietta Octavia Rowland Barnett, Practicable socialism, 1894, p.208

432 Barnett, Samuel Augustus and Henrietta Octavia Rowland Barnett, Practicable socialism, 1894, p.208

433 Barnett, Samuel Augustus and Henrietta Octavia Rowland Barnett, Towards Social Reform, 1909, p.173
} 
sense. ${ }^{434}$ Beyond the idea of humanity as the motivating force behind social reform as advocated by Headlam and Booth, Barnett also appealed to the needs of the political nation and invoked arguments which pointed towards the debate on national efficiency. In her emphasis on national growth and well-being, she anticipated the arguments proffered by the non-Christian thinkers in Chapters Six to Eight of this thesis.

Barnett defined her fundamental motivation in social work as Christian. But unlike Headlam and to some extent Booth, she did not explicitly resort to her creed as a blueprint of how to reconstruct society. Religion, in her understanding, played the part of a motivational force. She held that nothing but belief in a just and benevolent God could stir men from their apathy towards their fellow human beings and motivate them to work towards a better future ${ }^{435}$. In her eyes, utopias and republics, whether of Plato or William Morris, of socialists or individualists, constituted attractive visions, but were too remote and unrealistic to raise the enthusiasm necessary to conquer difficulties and to call out sacrifice. "Religion, which is the consciousness in men's selves of a force higher and greater than themselves, is, in a word, the only power which makes men willingly surrender their rights and be persistent in well-doing, and religion has been the unfailing motive to social reform", she wrote in the Introduction to Towards Social Reform, a collection of essays published in cooperation with her husband ${ }^{436}$. Barnett shared the belief prevalent in Headlam's thought that service rendered towards one's less fortunate fellow-men constituted the best, and possibly only valuable, service towards $\operatorname{God}^{437}$. Men and women were sent into this world to be one another's servants. Like Headlam, Barnett held that salvation could not be attained through individualistic piety, but only through an active communal life. In her eyes, no one could hope to be "saved" who did not willingly give himself to save others. Her belief in a communion of men in the service of God motivated her to ceaselessly work for a more just and equitable society.

Her approach to social reform envisaged personal devotion to the cause and a willingness to physical as well as emotional sacrifice. In all her social endeavours, she demanded first and foremost the application of "human love to human needs" ${ }^{438}$. She believed fervently in the reformatory powers of individual initiative. The individual, she believed, was the agency best placed to help the growth of individuality in others. "It takes a soul to raise a soul", Barnett summarised her belief in personal influence, a belief we have already encountered also in the thought of William Booth; "the secret of success of religious bodies is that they fearlessly use the

\footnotetext{
434 Barnett, Henrietta Octavia Rowland, Science and City Suburbs, 1906, p.56

435 Barnett, Samuel Augustus and Henrietta Octavia Rowland Barnett, Practicable socialism, 1894, p.219

436 Barnett, Samuel Augustus and Henrietta Octavia Rowland Barnett, Towards Social Reform, 1909, p.16

437 Barnett, Samuel Augustus and Henrietta Octavia Rowland Barnett, Towards Social Reform, 1909, p.18

438 Barnett, Samuel Augustus and Henrietta Octavia Rowland Barnett, Towards Social Reform, 1909, p.11
} 
influence of individual character on individual character." ${ }^{439}$ It was a course she wished to see adopted by any agency working towards social reconstruction.

Barnett doted on the personal influence and example brought to bear upon the destitute through direct contact and individual friendships between members of all classes. Friendship alone, meaning emotional involvement of one with the other, she believed, ensured an understanding deep enough to produce mutual respect and cooperation towards social improvement. Her faith in the powers of friendship stemmed from her early experiences at Toynbee Hall. "Their activities have been unceasing and manifold", she wrote of the inhabitants of the settlement, "but looking over many years and many men, it seems to my inferior womanly mind that the best work has been done by those men who have cared most deeply for individuals among the poor." ${ }^{440}$ Care for the degraded, she observed, aroused the poor to care for themselves. Restoring individuals to a state of dignity, pride and human worth through sympathy, respect and understanding appeared to Barnett the best possible result to be achieved in her efforts towards social reform ${ }^{441}$.

In view of her emphasis on individual initiative and personal effort, it comes as no surprise that Henrietta Barnett remained a life-long member of the Charity Organisation Society which attached great importance to the role of character in its relief work. But her personal experience as a resident of Whitechapel led her early on to be critical of some of the Society's methods and aims. She lamented the ingrained conservatism of the organisation which rendered it inflexible and narrowminded $^{442}$. Although the word charity, which Barnett translated as love, figured prominently in its name, she criticised that the organisation appeared persistent in thinking evil and assuming the worst about its clients. "Some people fear the devil more than they love God", she described the problem she saw with the work of the Charity Organisation Society; "or, in other words, they fear to do harm more than they love to do good." 443 Barnett came to wish for a more open-minded and large-scale approach to relief work; one which did not get stuck with petty tests of character and respectability, but assumed the basic human dignity of all men and women and accepted the influence of conditions upon individual lives.

Barnett distanced herself from the view of the Charity Organisation Society that poverty was to a large part the fault of the individual and lay within the individual's power to remedy. Twenty years among the poor and destitute at Whitechapel had convinced Barnett that poverty was a problem not only of national dimensions, but also of national making and with national repercussions. The individual poor was in most cases a victim of circumstances rather than of his own character

\footnotetext{
439 Barnett, Samuel Augustus and Henrietta Octavia Rowland Barnett, Towards Social Reform, 1909, p.172

440 Barnett, Samuel Augustus and Henrietta Octavia Rowland Barnett, Towards Social Reform, 1909, p.252

441 Barnett, Samuel Augustus and Henrietta Octavia Rowland Barnett, Towards Social Reform, 1909, p.253

442 Barnett, Samuel Augustus and Henrietta Octavia Rowland Barnett, Practicable socialism, 1894, p.211

443 Barnett, Samuel Augustus and Henrietta Octavia Rowland Barnett, Practicable socialism, 1894, p.213
} 
failings. He was not usually the irresponsible idler who could, but would not, work against whom both the Poor Law and the Charity Organisation Society proceeded. "'Able-bodied'. (...) What a cruel contradiction the word is to the gaunt creature which arises before those of us who know him individually, or have seen him as a stranded derelict before the workhouse gates", she expressed her outrage at the above view; "feeble-bodied, flabby-minded, crooked-souled would be the better description." ${ }^{\prime 44}$ Thin, pale, self-respect absent from his gait and manners, the pain of the hunted stamped on his features, Barnett postulated, he needed food, clothes and rest in order to restore $\operatorname{him}^{445}$.

This so-called able-bodied pauper constituted a disgrace and, more still, a danger to the community which had allowed him to deteriorate thus. Did it not therefore, Barnett asked, become the community's responsibility to restore him to industrial efficiency and alter the conditions of life so as to prevent men from sinking to such levels of destitution? 446 "It is not by any charitable effort that this poverty must be fought", she wrote. "A national want must be met by a national effort." ${ }^{447}$ As she grew increasingly sceptical of the amateur approach and the moral high horse of private institutions, Barnett began to accept state aid as a useful and legitimate means of social reform. For her, state action found its justification in as far as it helped or hindered the growth of individual character and thus added to the total of common wealth. The true test of any proposal, she believed, - be it a bill for town planning, or for the unemployed, or be it an appeal to establish an institution for cripples or holiday children - was whether or not it brought out the "power of being" in the people it reached, and whether it increased the sum of peace and goodwill within the nation. "We would (...) limit State action", she defined her new stance in conjunction with her husband in the preface to Towards Social Reform, "wherever it interferes with the growth of manhood and womanhood in the nation, and enlarge its actions wherever it could assist this growth." 449

Social reform, in Barnett's eyes, was central to the welfare and progress of the nation as a whole. However amazing the growth of national wealth since the industrial revolution appeared in absolute figures, she feared that the economic inefficiency resulting from poor health and malnutrition of the great majority of her population held Britain back in the competitive race between the nations. "Statistics, however flattering, do not tell the whole truth about increased national prosperity, or about progress in development, if there is a pauper class constantly increasing, or a criminal class

\footnotetext{
${ }_{444}$ Barnett, Samuel Augustus and Henrietta Octavia Rowland Barnett, Towards Social Reform, 1909, p.164

445 Barnett, Samuel Augustus and Henrietta Octavia Rowland Barnett, Towards Social Reform, 1909, p.164

${ }_{446}$ Barnett, Samuel Augustus and Henrietta Octavia Rowland Barnett, Towards Social Reform, 1909, p.160

447 Barnett, Samuel Augustus and Henrietta Octavia Rowland Barnett, Practicable socialism, 1894, p.28

448 Barnett, Samuel Augustus and Henrietta Octavia Rowland Barnett, Towards Social Reform, 1909, p.13

449 Barnett, Samuel Augustus and Henrietta Octavia Rowland Barnett, Towards Social Reform, 1909, p.13
} 
gaining its recruits from the victims of poverty" ${ }^{450}$, she warned.

She also stressed the political aspect of interior stability and safety in her endeavours at social improvement. Since the franchise reforms of 1867 and 1884, sections of the working classes had been granted a share in government and on them, Barnett argued, progress depended. Without adequate education and without the leisure and means to keep themselves informed about the affairs of the nation, however, they necessarily lacked the wider outlook which took into account the welfare of the whole of society. Self-government was in itself no security against either a wicked or a foolish policy, Barnett warned. She pointed out that democracy was nothing more than an instrument to be turned to base or beneficent use, depending upon the influence exerted upon the decisive majority. In her eyes, it lay in the interest of all members of society to ensure that an atmosphere of love and justice prevailed throughout the community which could counteract narrow class interest and selfish motives in politics ${ }^{451}$. In this context, Barnett also worried about the decline of religion among the lower strata of society. She dreaded the absence of "that knowledge of the All Loving and All Good which will constrain them to be wide-minded and persistently-minded in social reform" $" 452$.

Despite her increasing willingness to employ state aid in social reform, Henrietta Barnett was careful about calling herself a full-blown socialist. In her opinion, both socialism as well as individualism pursued too abstract a vision. In her approach to reform she resembled William Booth. Like the general, she favoured measures which were both practicable and showed immediate results. She held that progress, like walking, depended on the use of both the far sight as well as the near sight. "Men must lift up their eyes to the distant prospect or they will have no heart to go on", she explained; yet, "they must also take note of the path at their feet or they will stumble and go astray" ${ }^{453}$. Socialists and individualists both fell into the same trap of being caught up with the faroff view of a socialistic ideal. Socialists, looking to a land flowing with milk and honey, insisted on immediate occupation and refused to accept measures falling short of their ideal. Individualists, on the other hand, terrified of a future where all means of production were in the public hand rejected any proposal, however promising, which seemed to move in that direction. Socialists and individualists both, in Barnett's opinion, shut their eyes to immediate needs. She found them both apt to forget that the far-off prospect was always more or less an illusion which did indeed contain a kernel of truth, but one which could be spoken of only in the language of poetry and not in the language of science. "The Israelites", she quoted the Bible to illustrate her point, "found no land of

\footnotetext{
450 Barnett, Samuel Augustus and Henrietta Octavia Rowland Barnett, Practicable socialism, 1894, p.12

451 Barnett, Samuel Augustus and Henrietta Octavia Rowland Barnett, Towards Social Reform, 1909, p.18

452 Barnett, Samuel Augustus and Henrietta Octavia Rowland Barnett, Towards Social Reform, 1909, p.17f.

453 Barnett, Samuel Augustus and Henrietta Octavia Rowland Barnett, Towards Social Reform, 1909, p.9ff.
} 
milk and honey; but the hard contest by which Palestine was conquered was the foundation of the wealth and peace which they enjoyed under Solomon."

Barnett believed in the possibility of progress and in a future better than the present. But her life as a parson's wife at Whitechapel and her earlier experiences at St. Mary's had impressed on her the human dimension of the social problem. For Barnett, overcrowding, disease and high mortality rates constituted not abstract figures in a social survey and argumentative ammunition to be used in ideological wars, but very personal everyday experiences which required immediate amelioration. "Practicable Socialism", the title of another collection of essays written in collaboration with her husband, aptly describes her attitude to social reform ${ }^{455}$. "We do not dismiss the details of any ideals, or of any far off visions", Henrietta and Samuel Barnett explained; "we believe that somehow good will come, and we desire to unite all parties to use their near sight and do the next good thing which lies at their feet." ${ }^{\prime 56}$

Barnett took a balanced stance in the ideological debate on state aid versus voluntarism. Official organisations, she came to see in the course of her social work, such as government departments and municipal authorities had an efficiency, a command of resources and a persistence of effort rare in organisations which depended upon voluntary effort and philanthropic donations. At the same time, however, Barnett marked critically the tendency of official authorities to take a purely administrative approach to social problems and to overlook their human dimensions, the lives, joy and suffering of individuals. In her opinion, the best results would be achieved by a combined effort of state and voluntary agencies. "The ideal force to obtain reforms is that the whole community should care", she wrote, "but it cannot care without knowing, and in order to know it must see from within." ${ }^{457}$ Barnett aimed at coupling personal empathy with institutional efficiency, the emotional resources of the individual with the financial and human resources of the state.

By contrast to Stewart Headlam, and in keeping with the thought of William Booth, Henrietta Barnett was no leveller. She did not believe in equality. In her mind, each class and each individual had its specific characteristics which would, if properly developed, help it to fill its assigned place in society. She envisaged a community where conditions, as mountains in a landscape, only made for a variety in the level of humanity. A flat country, she argued, was dull; mountains and valleys gave interest to a landscape. "[T] he hills lend their beauty to the dales - their torrents fertilise the low-lying lands, and the lofty mountain crag which first gains the light, and is the last to lingeringly let it go, gives back its reflected glory to gladden the shadowed valley" ${ }^{458}$, she gave as an analogy to

\footnotetext{
${ }^{454}$ Barnett, Samuel Augustus and Henrietta Octavia Rowland Barnett, Towards Social Reform, 1909, p.10

455 Barnett, Samuel Augustus and Henrietta Octavia Rowland Barnett, Practicable socialism, 1894

456 Barnett, Samuel Augustus and Henrietta Octavia Rowland Barnett, Towards Social Reform, 1909, p.15

457 Barnett, Samuel Augustus and Henrietta Octavia Rowland Barnett, Towards Social Reform, 1909, p.172

${ }_{458}$ Barnett, Samuel Augustus and Henrietta Octavia Rowland Barnett, Practicable socialism, 1894, p.219
} 
describe how she imagined social classes to live off each others' traits and virtues. Barnett saw no alternative to the organisation of society into a hierarchy of classes. In her eyes, each class fulfilled a special, and essential, role in the nation's life. Her concern in social reform centred upon an equal opportunity for each member of society to choose for him- or herself the "higher or lower life 'in that state of life in which it has pleased God to call us'". It is interesting to contrast her rendering of the Biblical phrase with Stewart Headlam's citing of it. While Headlam allowed for the possibility of social mobility to that state in life to which it shall please God to call man, Barnett considered social status to be fixed. Barnett's interest lay in the development of humanity and character in the social situation entered into upon birth, not in the improvement of status and in social rising. Like William Booth, Barnett set out to alter conditions in order to free man to seek his highest self as a member of the class into which he had been born. ${ }^{459}$

\title{
3. The Basic Evil: Social Division
}

\author{
c) Economic Division
}

Barnett identified the basic evil of modern life as what one might call the fragmentation of society. In her view, the division was threefold. One part was economic in cause and nature. Barnett denounced the fact that alongside an immense increase in the combined wealth of the British nation with industrialisation, the number of people living in dire poverty had also soared to unprecedented heights. While more than half the English people lived on the brink of destitution, Barnett would not believe in British supremacy and the country's greatness. "It is useless", she explained, "to imagine that the nation is wealthier because in one column of the newspaper we read an account of a sumptuous ball or of the luxury of a city dinner, if in another column is a story of 'death by starvation'." 460

In an article first published in the National Review in the summer of 1886, she brought home to her readers the hard reality of life on an average wage of a pound a week. The provision even of basic necessaries for a healthy and decent life was impossible on so low an income, Barnett aimed to show. Food took up the major part of a working man's income. It was also the area where a poor

\footnotetext{
459 Barnett, Samuel Augustus and Henrietta Octavia Rowland Barnett, Practicable socialism, 1894, p.208

${ }^{460}$ Barnett, Samuel Augustus and Henrietta Octavia Rowland Barnett, Practicable socialism, 1894, p.12
} 
family could most easily cut down and save an extra penny. Barnett reckoned up for her readers that even a very drear and basic diet of bread, pulses, rice pudding and tea cost a family of maybe ten an average of $2 \mathrm{~s} 5 \mathrm{~d} \mathrm{a} \mathrm{day}{ }^{461}$ or a total of $16 \mathrm{~s} 4 \mathrm{~d}$ a week. With an income of a pound a week, the family was thus left with $3 \mathrm{~s} 8 \mathrm{~d}$ to pay rent, obtain schooling for the children, to buy coals, clothes and boots, to meet the doctor's bills, to join a club against sickness, death or unemployment and to cover for breakages and necessary replacements.

Impossible, Barnett held, considering that decent accommodation of two rooms in London could not be had for less than $5 \mathrm{~s} 6 \mathrm{~d}$ a week; and so this already insufficient diet was cut down even further. "The children have to put up with less than they need; the mother 'goes without sooner than let the children suffer', and thus the new baby is born weakly and but half-nourished" ${ }^{\text {"462, Barnett }}$ explained. She detected a certain irony in the fact that even the workhouse at Whitechapel customarily served meat three times a week, supplementing the meals with bread and butter or lard, suede pudding or cocoa. The costs for the weekly rations of inmates ran to about $3 \mathrm{~s} 11 \mathrm{~d}$ per person, a figure far beyond the means of the average wage earner. Barnett considered it absurd and outrageous that a man in employment could not by his labour sustain his family as well as the pauper was kept under the Poor Law principle of Less Eligibility. ${ }^{463}$

Barnett felt sure that on so scanty a diet, robust health could not possibly be maintained. She attacked the philanthropic spirit of the age which prided itself on heavy subscriptions to hospitals, schools and sick-asylums while considering $£ 1$ a week for a working man and as little as 9s for an unskilled working woman a fair wage. On so low an income the working man must fail to replenish his resources, the unemployed soon became unemployable. Barnett pointed to the children who grew up physically weak and defective and teachers trying in vain to develop malnourished brains. "By the door-way of semi-starvation disease is invited to enter and find a home among the masses of our wage-earning people" ${ }^{\prime 464}$, Barnett wrote. As long as wages remained at the present rate, she deduced, the large mass of the British people could not afford the food necessary to maintain them in robust health - and bodily health alone, she added, was here considered.

The body's needs were the most exacting and needed to be satisfied before all else, Barnett recognised. She held, however, that a fair wage must allow a man not only to adequately feed himself and his family, but also to provide the means of "mental cultivation and spiritual development" ${ }^{\prime 65}$. Economic hardship prevented the individual from developing to its fullest potential. She believed that the loss which resulted from thousands of stultified lives hit the nation

\footnotetext{
461 Barnett, Samuel Augustus and Henrietta Octavia Rowland Barnett, Practicable socialism, 1894, p.16

${ }_{462}$ Barnett, Samuel Augustus and Henrietta Octavia Rowland Barnett, Practicable socialism, 1894, p. 17

463 Barnett, Samuel Augustus and Henrietta Octavia Rowland Barnett, Practicable socialism, 1894, p.21

${ }_{464}$ Barnett, Samuel Augustus and Henrietta Octavia Rowland Barnett, Practicable socialism, 1894, p.20

${ }^{465}$ Barnett, Samuel Augustus and Henrietta Octavia Rowland Barnett, Practicable socialism, 1894, p.26
} 
as a whole as much as it did the individual. "While more than half the English people are poor, weak and unable to live their best life or reach their true standard of humanity", Barnett admonished her fellow-citizens, "it is useless to congratulate ourselves on our national supremacy or class our nation as wealthy and strong." ${ }^{\circ 66}$

b) Geographical Division

Another part of the problem of poverty as Barnett saw it lay in the fact that parallel to the economic fragmentation of society ran a topographical fragmentation. "The inhabitants of London are no longer the inhabitants of one town" 467 , she noted. The metropolis and other industrial centres grew ceaselessly with new neighbourhoods reaching further and further into the surrounding countryside. In these new suburbs, the classes were divided as definitely as in the towns themselves. While the poor lived in "miles of mean streets" 468 , without trees, open spaces and fresh air, those who could afford the higher rents moved to neighbourhoods where houses were surrounded by gardens, and where open spaces allowed for air and sunlight. Was that state of things a necessity of modern civilisation? Barnett asked. "Must we be content", she demanded to know, "now that education is bringing all sorts of people nearer together in sympathy, to have classes topographically divided by an arbitrary division depending upon their rent-paying powers?" 469

Barnett readily conceded that in matters of housing, progress was being made in the period between 1880 and 1914. She quoted private attempts such as the schemes of Octavia Hill or the Peabody Trust $^{470}$ as well as public measures such as Part III of the 1890 Housing Act which allowed county councils to purchase land outside their borders in order to provide housing for the working classes. All of these attempts, Barnett stressed, constituted a considerable improvement on the state of housing hitherto found. And yet, all of them fell into the same trap: the trap of providing for one class only. The new estate at Tottenham purchased and erected by the London County Council (LCC) housed 42.500 people all of which belonged to the industrial classes. The LCC estate at West Ham provided accommodation for as many as 300.000 persons, not 500 of whom could afford to keep a servant ${ }^{471}$. This separation of classes into different districts carried, Barnett feared, social and

\footnotetext{
466 Barnett, Samuel Augustus and Henrietta Octavia Rowland Barnett, Practicable socialism, 1894, p.28

467 Barnett, Henrietta Octavia Rowland, Science and City Suburbs, 1906, p.54

468 Barnett, Samuel Augustus and Henrietta Octavia Rowland Barnett, Towards Social Reform, 1909, p.332

469 Barnett, Samuel Augustus and Henrietta Octavia Rowland Barnett, Towards Social Reform, 1909, p.333

${ }^{470}$ George Peabody (1795 - 1869) was a London-based American banker and philanthropist. In 1862, he established the Peabody Trust to provide affordable housing for the poor.

471 Barnett, Henrietta Octavia Rowland, Science and City Suburbs, 1906, p.53
} 
economic disadvantages. "The English system of government is based on the belief that there is in every district a leisured and cultivated class able to give time and thought to municipal and other public duties", she believed, "and when such a class is absent the whole suffers both financially and ethically." 472

The loss to the community took several forms. Barnett lamented the great waste of money resulting from unqualified local councils or Boards of Guardians who, due to a lack of training, skill and experience, vacillated in their policies or entered upon undertakings for which they had not calculated the costs. Money was also lost to individuals. The workman who was employed on a building site in the West End had to travel four or five miles to his place of work spending time and money for which neither he nor the community got any return ${ }^{473}$. The topographical division also produced secondary costs to the community. The citizens of a neighbourhood such as Whitechapel or West Ham had no resources on which to draw so as to provide proper schools or decent health care facilities. The lack of either added to the mass of unemployed and unemployable and cost the tax-payer heavily in the form of poor relief. ${ }^{474}$ Barnett also pointed to the lack of beauty, light and air in the crowded poor neighbourhoods. Such living conditions, she believed, produced illness, dullness and unhappiness and thus tended towards economic inefficiency and the reduction of national wealth. "It pays to make the workpeople happy" ${ }^{475}$, she impressed upon her readers.

Barnett employed the economic argument purposely to shake into action those of her readers who had hitherto been inclined to think, as she put it, with their purses rather than with their hearts. Her husband's residential project at Toynbee Hall, Barnett's own home for more than ten years by the time of the article quoted, marked an artificial protest against the massing in one locality of the poor and an attempt to remedy the problem of the missing cultured class.

\section{c) Cultural Division}

There was a third, cultural facet to the social fragmentation which Barnett identified as the basic evil of modern Britain. The topographic division of classes into far-apart neighbourhoods led to mutual estrangement - which in turn tended to produce first ignorance of one another's ways, then distrust and finally resulted all too often in open hostility. Barnett considered mutual estrangement to be the most dangerous and harmful consequence of social fragmentation. With the example of the

\footnotetext{
472 Barnett, Samuel Augustus and Henrietta Octavia Rowland Barnett, Towards Social Reform, 1909, p.338

473 Barnett, Henrietta Octavia Rowland, Science and City Suburbs, 1906, p.55

474 Barnett, Henrietta Octavia Rowland, Science and City Suburbs, 1906, p.54

475 Barnett, Henrietta Octavia Rowland, Science and City Suburbs, 1906, p.55
} 
Russian Revolution of 1905 before their eyes, Barnett warned her readers in 1906, Britain must recognise that the strength of a nation depended upon mutual trust, understanding and respect. "The soil of suspicion cannot produce the strong tree in whose branches its people rest in happy security, or whose leaves heal the waters of internal strife ${ }^{\text {‘ } 476}$, she said.

The mention of the poor brought up in most wealthy people's minds scenes of wretchedness, suffering, want and degradation. To many, poverty meant dirty and unkempt children, drink and gambling, domestic violence, rough language and street fights. Barnett countered that the mental image did not mirror reality. She pointed to the vast number of working men and women "who, while poor in money, [were] rich in life's goods" and lived quiet, thoughtful and dignified lives. "Riches are not necessary to refinement", Barnett insisted; “(...) some of the finest characters are developed under the enforced self-control of an income of a pound or thirty shillings a week." 477

There were, Barnett conceded, significant differences in the life styles and the popular culture of rich and poor. Yet, she defended the working classes against allegations of moral inferiority. The lower strata of society, she explained, simply did not get the chance to acquire what the upper strata defied as refinement and culture ${ }^{478}$. Many of the poor had no time to spare for leisure activities between working, eating, sleeping and caring for the children. Even those with more restricted working hours often lacked the skills or resources necessary for wholesome recreation. Their lack of education left them unable to read the papers, their tight budget did not allow for the purchase of journals and books or a trip to galleries and museums ${ }^{479}$. The grey, narrow, uniform streets of destitute neighbourhoods failed to school the people's eye for beauty. To many of the poor, the most glorious sunrise constituted little more than an unwelcome intimation to get out of bed and to start another day of drudgery ${ }^{480}$.

Lacking the skill and energy for what Barnett considered character-forming, productive pastimes, the poor often resorted to the excitement of games of chance such as gambling, of street-fights and of drink. "The terrible and often deplored attraction of the public-house has its roots not so much in the love of strong drink as in the want of interest and desire for amusement felt by the lower classes of the poor" ${ }^{481}$, Barnett believed. Their ignorance of art and beauty did not signify an absence of capacity, but a lack of opportunity. Barnett held that all individuals, men and women, rich and poor, bore within themselves the full gifts and capabilities which made for „true humanity“. The dock labourer, Barnett felt sure, could admire fine art and music if only it was brought within his reach.

\footnotetext{
476 Barnett, Henrietta Octavia Rowland, Science and City Suburbs, 1906, p.54

477 Barnett, Samuel Augustus and Henrietta Octavia Rowland Barnett, Practicable socialism, 1894, p.88f.

478 Barnett, Samuel Augustus and Henrietta Octavia Rowland Barnett, Practicable socialism, 1894, p.208

479 Barnett, Samuel Augustus and Henrietta Octavia Rowland Barnett, Practicable socialism, 1894, p.149

480 Barnett, Samuel Augustus and Henrietta Octavia Rowland Barnett, Practicable socialism, 1894, p.209

481 Barnett, Samuel Augustus and Henrietta Octavia Rowland Barnett, Practicable socialism, 1894, p. 149
} 
The hooligan had powers of adventure and dreams of heroism. The drunkard often drank, she believed, because his thoughts were too big for his place in the world and the beggar had in him broken pieces of self-respect which appreciated courtesy and resented contempt ${ }^{482}$. Barnett believed in the capacity of every one to rise to his or her highest self as long as the opportunities for selfenlargement and education were offered to them. The daily lessons of beauty and refinement, which the inhabitants of the English village received through their close communion with members of higher social classes, were lacking acutely in the metropolitan slums.

Barnett chided the upper social classes for their shortsightedness in ascribing character deficiencies to the poor without realising their own shortcomings. The rich, Barnett argued, had lost touch with aspects of life which could bring out in the people true virtue and strength of character. Barnett lamented the absence among the better-off of "the priceless habit of personal sacrifice". Can a man live the highest life, she wanted to know, "from whom effort is undemanded - whose floors are padded should he chance to fall - whose walls, golden though they be, are dividing barriers, high and strong between him and his fellowmen?" ${ }^{483}$ Evil was wrought of ignorance as well as want of thought, Barnett argued, and the rich suffered from not knowing as much as the poor from not being known. ${ }^{484}$ She encouraged her readers to seek personal contact with members of the other classes. Coming face to face with the poor, she promised her well-off listeners, they would see patience which put their restlessness to shame, endurance about which poems had yet to be written ${ }^{485}$, meekness, unselfconsciousness, self-sacrifice and great hopefulness ${ }^{486}$. The foundations of both palace and shack, Barnett argued, were of the same material. The common ground between the classes needed rediscovering in the interests of both, individual and society.

\section{Towards Social Reform: The Magic Formula of Individuality in Community}

Henrietta Barnett's watchword in her approach to social reform read "community". It was a maxim she shared with her husband and which she had seen implemented on a small scale in Toynbee

\footnotetext{
482 Barnett, Samuel Augustus and Henrietta Octavia Rowland Barnett, Towards Social Reform, 1909, p.12

483 Barnett, Samuel Augustus and Henrietta Octavia Rowland Barnett, Practicable socialism, 1894, p.208

484 Barnett, Samuel Augustus and Henrietta Octavia Rowland Barnett, Practicable socialism, 1894, p.217

485 Barnett, Samuel Augustus and Henrietta Octavia Rowland Barnett, Practicable socialism, 1894, p. 164

486 Barnett, Samuel Augustus and Henrietta Octavia Rowland Barnett, Practicable socialism, 1894, p.209
} 
Hall ${ }^{487}$. By community, Barnett meant a sharing between members of all classes of one neighbourhood and one (broadly defined) culture. Most importantly, community for her entailed intimate knowledge of one another's character and ways brought about by personal contact and close individual friendships between members of all social strata. In her reform endeavours, Barnett pursued the dual aim of raising the poor from the confines of destitution and helping them to develop their personal capacity and at the same time furthering a sense of community and promoting contact between members of all classes based on a new sense of mutual sympathy and respect.

This dual strategy showed up particularly clearly in Barnett's work for and with the children of the poor. It may have been due to the traditional role of women and the fields of interest assigned to them in Victorian Britain, but also fits in with her keen interest in the individual, that Barnett took a particular interest in them, their living conditions and their chances in society. She felt particularly strongly about the child under state care - such as orphans, workhouse children, abandoned children, the criminal and the destitute. Her esteem for individuality and personal dignity led her to criticize severely the traditional institution of barrack schools, which received the brunt of statesupported children.

Barnett asserted for these children what she believed to be "every creature's inalienable right - the right to be treated as an individual" ${ }^{\prime 488}$. In the metropolitan area alone, Barnett estimated, there were approximately 10000 children under state care at the time of one article in $1886^{489}$. They were massed together in schools of 1000 inhabitants or more, regardless of the cause of their being under state care ${ }^{490}$. But the mentally and physically afflicted child, the morally depraved, children of respectable widows, the infant needing nursing and emotional care or the teenage boy and girl who required technical training, all had very different needs in terms of care and education. None of these needs, Barnett believed, could satisfactorily be taken care of in monster institutions such as the barrack schools at Sutton, Leavesden or Hanwel1 ${ }^{491}$. She recommended a system of boarding out in order to absorb state supported children into the general population. Instead of letting them grow into outcasts, she wanted to place these children firmly within the social community from as early an age as possible.

Her idea, Barnett argued, would save the public purse considerable amounts of money: while barrack schools cost $£ 29$ per annum per child, boarding out among respectable working class

\footnotetext{
487 Briggs, Asa and Anne Macartney, Toynbee Hall: the first hundred years, 1984; see also Meacham, Standish, Toynbee Hall and social reform 1880 - 1914: the search for community, 1987

488 Barnett, Samuel Augustus and Henrietta Octavia Rowland Barnett, Towards Social Reform, 1909, p.150

489 Barnett, Samuel Augustus and Henrietta Octavia Rowland Barnett, Practicable socialism, 1894, p.111

490 Barnett, Samuel Augustus and Henrietta Octavia Rowland Barnett, Towards Social Reform, 1909, p.129

491 Barnett, Samuel Augustus and Henrietta Octavia Rowland Barnett, Towards Social Reform, 1909, p.136
} 
families would cost the rate payer but $£ 13$ per head per year. Scotland and Switzerland boarded out the great majority of their young dependants; in Germany, a system of boarding out had become compulsory in 1878. In England at present, only about two percent of state-supported children were found placements among industrial families ${ }^{492}$. Barnett criticised the harm done to the nation's finances by the present system of barrack schooling.

But Barnett placed even greater emphasis than on the economic argument on the potential benefits accruing to the child from a system of boarding out. A place in a working class family, Barnett envisaged, would provide the destitute child with a stable environment, affection, play fellows and friends in higher classes of society. Barnett believed that as part of a family, a child would also necessarily be perceived as a person rather than a case and be allowed to develop a sense of self. Barnett held that "children do in this way get a truer knowledge of social relations and domestic work, and live, as members of a family, a more natural and healthy life"493. She hoped that through boarding out the child would lose all connection with pauperism and be so absorbed into the industrial classes as to require no further assistance in later life.

Barnett's faith in the powers of family life may tie back in with her religious faith although she did not explicitly refer to it. She held fast to the belief common among religious circles that the family was a divine institution created by God for the good of man ${ }^{494}$. On its preservation and on the "English love of home" ${ }^{\prime 45}$ depended, in Barnett's view, not only the future of the English nation, but of civilisation as a whole ${ }^{496}$. For Barnett, the family constituted a model of communal life to be emulated by society at large. She doted on the family dinner table as a moral training ground ${ }^{497}$. There, she enthused, the mother imparted to the children the little lessons of good manners and neat ways, and the large truths of unselfishness and thoughtfulness ${ }^{498}$. "Family life and affection is the foundation of all social welfare and morality"499, she quoted the child welfare campaigner Louisa Twining $^{500}$. To obtain it for the homeless child, Barnett was convinced, would immeasurably improve the community's future good, financially as well as morally and culturally.

\footnotetext{
492 Barnett, Samuel Augustus and Henrietta Octavia Rowland Barnett, Towards Social Reform, 1909, p.138

493 Barnett, Samuel Augustus and Henrietta Octavia Rowland Barnett, Practicable socialism, 1894, p.110

494 Barnett, Samuel Augustus and Henrietta Octavia Rowland Barnett, Towards Social Reform, 1909, p.172

495 Barnett, Samuel Augustus and Henrietta Octavia Rowland Barnett, Practicable socialism, 1894, p.28

496 Barnett, Samuel Augustus and Henrietta Octavia Rowland Barnett, Practicable socialism, 1894, p.123

497 Barnett, Samuel Augustus and Henrietta Octavia Rowland Barnett, Practicable socialism, 1894, p.28

498 Barnett, Samuel Augustus and Henrietta Octavia Rowland Barnett, Practicable socialism, 1894, p.28

499 Barnett, Samuel Augustus and Henrietta Octavia Rowland Barnett, Towards Social Reform, 1909, p.144

${ }^{500}$ Louisa Twining $(1820-1911)$, was a social activist. Twining took a particular interest in women and children.
} 


\section{Bringing out Individuality in the Poor}

For children who could not be placed out, barrack schools, if they were to be kept, urgently needed reforming. Here, too, Barnett focused on the harm done to the children in their personal development. One of the earlier articles under scrutiny in the present study attacked the strict discipline imposed in pauper schools. It tended to suppress any vestiges of individual personality in the children. "[D]iscipline too often begins to be admired for its own sake", Barnett stated, "and in certain schools one is shown, with pride, the children drilled into moving, even to eating and praying simultaneously, while order, cleanliness, and tidiness have become ends in themselves instead of means of education." ${ }^{501}$ Such discipline, she argued, crushed individuality and left no room for personal growth. It tended to make the pupils dull, sullen and mechanical, depriving them both of the joy of childhood and of subsequent strength in manhood. What child could be childlike, she asked, who lived by rules, who obeyed not for love's sake, but for necessity's sake; who had no room for choice or adventure, no experience for imagination? And what child, so drilled, could develop mechanisms and gather the strength necessary to hold impulse and passion in check? ${ }^{502}$ Barnett proposed several small changes which, in her eyes, would considerably improve barrack school education.

Her proposals underscore her supreme concern for a child's individuality. She recommended calling the children by their Christian names instead of by numbers ${ }^{503}$. Swimming lessons, musical lessons and field trips might all serve to spark new interests in a child and to develop individual talent and preference. In her article on barrack schools, Barnett related the story of a girl who, when confronted over the theft of a brooch from the cook, replied that she "did not mean to keep it, but (...) had never had one, and (...) wanted it for a bit" ${ }^{, 504}$. Barnett suggested to allow the children to keep possessions and to be given their own clothes, hoping that ownership would help to strengthen self-respect in the children and encourage habits such as tidiness and care. True to her belief in personal contact across the boundaries of class, she asked to enlist the services of lady visitors and girl volunteers, for instance in the school library, in Sunday School or for teaching games in the playground. Personal contact and friendship with the guests would, Barnett hoped, help to strengthen self-respect. Not least of all, the women would provide an example of "the good life"

\footnotetext{
501 Barnett, Samuel Augustus and Henrietta Octavia Rowland Barnett, Practicable socialism, 1894, p.112

502 Barnett, Samuel Augustus and Henrietta Octavia Rowland Barnett, Towards Social Reform, 1909, p.128

503 Barnett, Samuel Augustus and Henrietta Octavia Rowland Barnett, Practicable socialism, 1894, p.120

504 Barnett, Samuel Augustus and Henrietta Octavia Rowland Barnett, Practicable socialism, 1894, p. 112
} 
and offer contacts outside the school in higher classes of society ${ }^{505}$. Barnett aimed at bringing out a child's personality for the sake, first and foremost, of its inborn humanity. But she also hoped to derive benefits for the entire nation from her holistic approach to education which aimed at strengthening a child's inherent interests and capacities. Ultimately, Barnett envisaged, even the tiniest growth in individual character would add to the cultural and social stock of the nation and benefit the community as a whole.

Barnett's grasp of the young psyche was very advanced in that she considered play a necessity for children; in her articles on the barrack schools, she asked for working hours to be limited in order to make room for games ${ }^{506}$. For her, play constituted in itself a moral education. With the help of lady volunteers, Barnett hoped to teach games to children on the playground in order to impart lessons of fairness, unselfishness, adherence to rules and care for the weaker and younger ${ }^{507}$. She dreamed of turning the London play yards into "what the playing fields of Eton and Harrow are - the places where the best seeds of character take root and sprout" ${ }^{\mathrm{P} 08}$.

But not only the nation's children required, in Barnett's eyes, room for play and recreation in order to develop their full potential. She believed that adults needed as much opportunity for edification, constructive re-creation and self-enlargement as did the child. Evening classes, as offered for instance at Toynbee Hall, public libraries and foreign travel might all contribute to personal - and national - growth. So did athletics clubs and gymnasiums. "A people's play is a fair test of a people's character", she wrote. "Their recreation more than their business or their conquests settle the nation's place in history." ${ }^{509}$

Barnett deplored the consumerist attitude to leisure which she detected in the rush on music halls and popular theatres, in the new phenomenon of spectator sports and in the popularity of sea-side pleasure resorts She understood the need for excitement which led the less educated classes to betting, gambling, drinking, card-games or the occasional trip to Margate. The endless, tiring, monotonous hours in the factory or workshop left the working man and woman weary and killed off personal initiative. For them, the mostly effortless excitement of the above activities formed a relatively easy counter-balance to everyday drudgery. In Barnett's opinion, however, recreation must mean more than amusement and passing time; it meant the "refreshment of the sources of life" The fire of excitement formed a necessary first step to activating a person's resources, but unless fuel - some substantial achievement and personal gain - was supplied, the flames would soon sink

\footnotetext{
$\overline{505}$ Barnett, Samuel Augustus and Henrietta Octavia Rowland Barnett, Practicable socialism, 1894, p.118ff.

${ }^{506}$ Barnett, Samuel Augustus and Henrietta Octavia Rowland Barnett, Practicable socialism, 1894, p.116

507 Barnett, Samuel Augustus and Henrietta Octavia Rowland Barnett, Practicable socialism, 1894, p.224

508 Barnett, Samuel Augustus and Henrietta Octavia Rowland Barnett, Practicable socialism, 1894, p.223

509 Barnett, Samuel Augustus and Henrietta Octavia Rowland Barnett, Towards Social Reform, 1909, p.289

510 Barnett, Samuel Augustus and Henrietta Octavia Rowland Barnett, Towards Social Reform, 1909, p.291
} 
in ashes. Barnett believed that "pleasure should not only give enjoyment, it should also increase capacities for enjoyment" ${ }^{\text {"511 }}$. The people must be taught to enjoy themselves. She sought in leisure activities a strengthening of a man's whole being, the enrichment of memory, and the acquisition of skill.

Opportunities for such wholesome recreation she found in music, books, athletics, cycling, walking tours, photography or games of skill ${ }^{512}$. Among the leisure activities of which she approved, museums and picture galleries occupied a prominent place. Her belief in the ability of all, educated as well as uneducated, to understand and appreciate beauty prompted her to play an instrumental part in the opening of the Whitechapel Art Gallery. The Gallery was designed to put into the reach of the poor means of self-enlargement which had hitherto been available almost exclusively to the rich $^{513}$. Art museums had wrongly been thought of chiefly as pleasure places for the educated, or as schools for the student. Barnett aimed to turn them into mission-halls for the degraded ${ }^{514}$.

The success of the first two experimental exhibitions before the institution of a permanent gallery proved her right. More than 9000 people visited the first exhibition, the second was seen by almost 26.500 men, women and children from Whitechapel and the surrounding neighbourhoods ${ }^{515}$. "[Their] plain, direct method of looking at things enables them to go straight to the point", Barnett related her impressions, "and perhaps to reach the artist's meaning more clearly than some of those art critics whose vision is obscured by thoughts of 'tone, harmony, and construction'."516 The capacity for perceiving the hidden meaning of art was, she believed, innate and schooled as much by life's experiences - of which the poor had more than enough - as by scholarship of which they had naturally very little. Barnett placed great hopes on art to inspire and "keep alive the nation's fading higher life". Pictures spoke to the educated as well as the illiterate in a way which, she believed, went straight to the heart. "Words, mere words, fall flat on the ears of those whose imaginations are withered and dead", she stated; "but art, in itself beautiful, in ideas rich, they cannot choose but to understand, if it be brought within their reach." ${ }^{517}$

\footnotetext{
$\overline{511}$ Barnett, Samuel Augustus and Henrietta Octavia Rowland Barnett, Towards Social Reform, 1909, p.290

512 Barnett, Samuel Augustus and Henrietta Octavia Rowland Barnett, Towards Social Reform, 1909, p.293

513 Barnett, Samuel Augustus and Henrietta Octavia Rowland Barnett, Practicable socialism, 1894, p. 175

514 Barnett, Samuel Augustus and Henrietta Octavia Rowland Barnett, Practicable socialism, 1894, p.97

515 Barnett, Samuel Augustus and Henrietta Octavia Rowland Barnett, Practicable socialism, 1894, p.177

516 Barnett, Samuel Augustus and Henrietta Octavia Rowland Barnett, Practicable socialism, 1894, p. 178

517 Barnett, Samuel Augustus and Henrietta Octavia Rowland Barnett, Practicable socialism, 1894, p.187
} 


\section{The Edifying Effects of Nature}

In her search for simple and easily accessible means of education and recreation, Barnett also explored the edifying effects of nature. Early on in her social activism, she showed leanings towards the back-to-the-land myth. While ignorance or lack of money kept many pleasures from the working classes, she reasoned that it was possible for the rich as well as the poor to enjoy the countryside with its natural beauty ${ }^{518}$. Not the least of her achievements was her contribution to the founding of the Children's Country Holiday Fund. In the year 1893, which she gave as an example of the undertaking's success in one of her articles, the Fund sent approximately 30.000 children from London on a fortnight's holiday to the countryside ${ }^{519}$. Barnett believed that the excursion would benefit the children in their personal development by schooling the powers of observation and awakening intellectual curiosity ${ }^{520}$ in a way impossible in the dreary grey city neighbourhoods. "Children need to be taught to enjoy as much as they need to be taught to work" ${ }^{521}$, she wrote.

Barnett considered nature the most apt and patient instructor to draw out a child's undiscovered powers. If teachers and hosts took the trouble to interest the children in what may be seen in a country lane, or to observe the birds and insects living on a pear tree, the children would, she believed, develop more lively minds and acquire the skills necessary to enjoy themselves, on their country holidays as well as back home in their often dull and uniform urban environment. She asked her readers to contribute to the scheme, either financially or by giving one's time and ideas, in order to "fill their country fortnights with thoughts, ideals, new games, play handicraft, and home occupations, which may not only make gladder the fortnight in the country, but help to enlarge their store-rooms of good memories and keep the children more out of the streets when again amid the four million town livers" ${ }^{\prime 522}$.

Adults, too, Barnett envisaged, would benefit greatly from an introduction to nature. In an article entitled "At home to the Poor" she asked women from the higher strata of society to play host to groups of slum dwellers for a garden party at their country homes. "Believing that [the poor] had the same need of social intercourse as that felt by the rich, and taking for granted that the kind of country entertainment most prevalent among the rich was that most enjoyed, we based our parties on the same foundation" ${ }^{523}$, she wrote. Here again, Barnett considered the poor and the rich to be of

\footnotetext{
518 Barnett, Samuel Augustus and Henrietta Octavia Rowland Barnett, Practicable socialism, 1894, p. 150

519 Barnett, Samuel Augustus and Henrietta Octavia Rowland Barnett, Practicable socialism, 1894, p.52

520 Barnett, Samuel Augustus and Henrietta Octavia Rowland Barnett, Towards Social Reform, 1909, p.307

521 Barnett, Samuel Augustus and Henrietta Octavia Rowland Barnett, Towards Social Reform, 1909, p.319

522 Barnett, Samuel Augustus and Henrietta Octavia Rowland Barnett, Towards Social Reform, 1909, p.329

${ }_{523}$ Barnett, Samuel Augustus and Henrietta Octavia Rowland Barnett, Practicable socialism, 1894, p.153
} 
similar stock and to have similar needs and appetites. By way of entertainment at the garden parties, Barnett recommended food and drink and games like cricket or bowling. The greatest impression on the minds of the slum dweller, however, she expected from nature herself. "For people spending long years in the close courts and streets of ugly towns", she predicted, "the mere sight of nature is startling and may awaken longings, to themselves strange and indescribable, but which are the stirrings of the life within." 524

With the idea of at homes in the country Barnett revealed herself as a faithful adherent to the idea that the land had a healing, reconstituting effect upon the town dweller. The sweetness of the air, the quiet, the colours and scent of flowers and trees, the very fact of strolling in the road on their way to their host's place without looking out to avoid being run over, all these little pleasures of the countryside provided a relief, Barnett believed, difficult to understand for those who did not live in close streets and amid noise and grinding hurry ${ }^{525}$. Nature's lure was stronger than poverty and destitution, Barnett held, and its positive effects unparalleled. Barnett told of terminally ill men and women who rose from their death beds to take up an invitation to an ,at home". In her emphasis on the idea of natural beauty which contrasted urban ugliness and upon the healthy effects of sunshine and fresh air Barnett re-iterated aspects of the back-to-the-land movement.

True to her ideal of communion and personal relations between the classes, Barnett expected secondary benefits from such parties. The beauty and style of the country homes, she hoped, would have a civilising influence on the rough. Barnett recounted the tale of a fifteen-year old who, invited by her country hostess to see the whole house, excitedly exclaimed: "Look, mother, here's a bed with a room all to itself!" 526 Well-kept mansions might, she endeavoured, encourage tidiness and cleanliness in many a woman slum dweller. Not least of all, Barnett believed that such parties would introduce rich and poor to one another, have them share experiences and subsequent memories, and provide a subject regarding which they could, at least for an afternoon, be of one mind and purpose $^{527}$."The wider interests, the seeds of culture, the introduction to simple recreations, the suggestion of ideal beauty, the possession of happy memories, the class relationships, are the advantages one can rapidly count off as accruing to the entertained, and as important are the gains to the entertainer" ${ }^{\prime 528}$, she listed. Rich and poor both had their virtues, and the division of classes constituted a loss to both, Barnett did not tire to emphasise. But given the greater means of the welloff, it was for them to take the first step towards knowing and being known.

\footnotetext{
${ }_{524}$ Barnett, Samuel Augustus and Henrietta Octavia Rowland Barnett, Practicable socialism, 1894, p.95

${ }_{525}$ Barnett, Samuel Augustus and Henrietta Octavia Rowland Barnett, Practicable socialism, 1894, p.155

526 Barnett, Samuel Augustus and Henrietta Octavia Rowland Barnett, Practicable socialism, 1894, p.159

527 Barnett, Samuel Augustus and Henrietta Octavia Rowland Barnett, Practicable socialism, 1894, p.161

${ }_{528}$ Barnett, Samuel Augustus and Henrietta Octavia Rowland Barnett, Practicable socialism, 1894, p. 164
} 


\section{Poor Law Reform}

We have seen that in Henrietta Barnett's articles, cited in the present study, one detects a development in social thought and enlargement of perspective. Although the writer remained true to her emphasis on personal initiative and responsibility which had led her to join the Charity Organisation Society, in the course of the three decades from 1880 to 1909, she added to her framework for social reform projects on a semi-private basis such as art galleries and libraries. She finally also came to accept the state as a useful and necessary agent of reform. For Barnett, social reform was an ongoing process which demanded constant enlargement of thought and perspective and continual adjustment of means and aims. All measures of reform, whether private or state-run, constituted but means to an end and needed to be continually reconsidered so as not to become outdated. Laws constituted no exception in Barnett's mind. She gave the example of the Building Act of 1890 which had done much to improve public health, but now imposed ugliness on whole districts and reinforced the segregation of classes. The Poor Law, too, which had been designed to stimulate the idle, now degraded many who would strive ${ }^{529}$. She called for the politician and the political economist - for the professional - to devote their time and thinking to the question, not of the production and accumulation of wealth, but of its right use and distribution ${ }^{530}$. She demanded a comprehensive rethinking of basic values, social parameters and possible solutions to the problems of society and a corresponding reform of social and political institutions.

Barnett focused upon the Poor Law as one among many legislative items in urgent need of reform. The two defining principles of the Poor Law, the Principle of Less Eligibility and the Principle of National Uniformity, had been formulated in 1834 with the express intention of correcting "the pass into which the lavish out-relief had brought the labouring population" ${ }^{231}$, and they had succeeded in doing so. In modern industrial urban society, however, conditions of life and work had rendered the above principles not only obsolete, but positively harmful. The ministrations of the Poor Law not only degraded the individual by reducing him or her to a "case" among many others, but had very real economic effects upon the community at large. Under the present system, $£ 13.000 .000$ of the public money were annually spent on ineffectual poor relief, an enormous loss to the common wealth. Barnett called for new principles to govern the Poor Law which aimed not at punishing the recipient through a strict application of less eligibility, but at restoring him to "Industrial

\footnotetext{
529 Barnett, Samuel Augustus and Henrietta Octavia Rowland Barnett, Towards Social Reform, 1909, p.12f.

530 Barnett, Samuel Augustus and Henrietta Octavia Rowland Barnett, Practicable socialism, 1894, p.28

531 Barnett, Samuel Augustus and Henrietta Octavia Rowland Barnett, Towards Social Reform, 1909, p.163
} 
Efficiency"532. Her ulterior motive was to get the pauper permanently off the rates, a goal not achieved by the workhouse system, and, in addition, to return him to a position where he could make his own contribution to the growth of the nation's wealth.

Barnett lamented the waste of resources, both financial and human, effected by the present system of Poor Law administration. She detected useful potential in every member of the community, however unemployable they seemed. Such potential, she demanded, should be used for the nation's social, cultural and economic growth rather than let go to waste at enormous costs to the public purse. The elderly, for instance, wasted away there potential in the workhouses. With their capacity for interest in others, with their wealth of unused affection and decades of homely wisdom born of experience, their industrial value consisted precisely in being old. Barnett recommended to take them out of the artificial life of institutions and return them to their families on pensions which would cost only about two-thirds of their present keep in the workhouse. In the interest of the community, they should not be locked away and degraded to the state of paupers, but be given the opportunity to pass on life's lessons to the young and untried ${ }^{533}$. Society, she wrote, banished to an uneventful life behind high walls its most effective teachers and patient nurses and then wondered at the high infant mortality among the poor ${ }^{534}$. "Loving and caring take time", she pointed out; "they appear in no trade list as marketable commodities, but they are the stock in trade of the old." 535 The nation needed their wares in the homes, she argued, not left dormant in institutions where they were wasted and, on top of that, cost the rate payer dearly.

The old Poor Law principles also did irreparable and costly harm to the children. In the interests of both individual and society, the community should aim at preparing them for industrial efficiency. Barnett demanded that as a first step they be altogether removed from the pauper class. "To allow a child either in his own mind or any one else's to be considered a pauper is to handicap his career" ${ }^{\prime 536}$, she argued. She proposed a new central authority charged with the care of all pauper children in order to take them away from the influence of Poor Law officials and ideas ${ }^{537}$. In her opinion, the new authority should be placed under the Education Department. The previous connection with the Local Government Boards tended to make pauper children a class apart from their contemporaries and tainted them for life. Nor had the Local Government Boards succeeded in doing justice to the special needs of these children in the past. "Children, with their tender natures, their delicate balance between good and evil, their insistent demands for individual treatment", she argued, "are

\footnotetext{
${ }_{532}$ Barnett, Samuel Augustus and Henrietta Octavia Rowland Barnett, Towards Social Reform, 1909, p.163

533 Barnett, Samuel Augustus and Henrietta Octavia Rowland Barnett, Practicable socialism, 1894, p.20

534 Barnett, Samuel Augustus and Henrietta Octavia Rowland Barnett, Towards Social Reform, 1909, p.167

${ }_{535}$ Barnett, Samuel Augustus and Henrietta Octavia Rowland Barnett, Towards Social Reform, 1909,p.168

536 Barnett, Samuel Augustus and Henrietta Octavia Rowland Barnett, Towards Social Reform, 1909, p.169

537 Barnett, Samuel Augustus and Henrietta Octavia Rowland Barnett, Towards Social Reform, 1909, p.149
} 
not an appropriate item in the immense organisation which has to do with drains, vagrants, asylums, guardian boards and workhouses, election orders, sanitary authorities, dangerous trades, and workshop inspection." ${ }^{938}$ Unlike the Local Government Boards, a central authority would be able to pool money as well as information, and place the individual child under that system of education best suited to develop its specific physical condition, mental capacity and individual aspiration ${ }^{539}$.

\section{Housing as the Key to Social Salvation: Hampstead Garden Suburb}

The project most firmly connected with the memory of Henrietta Barnett apart from Toynbee Hall doubtless is Hampstead Garden Suburb. The undertaking encompassed several of her central tenets in social reform, her insistence on personal development, her demand for restoration of the poor to industrial efficiency, her belief in the beneficial powers of nature, and most of all, her emphasis on community and close personal contact. "People cannot live by bread alone", she wrote in an article on the Garden Suburb project. "They need the stimulus of various interests, contact with nature and the neighbourhood of other classes to stir their minds and aspirations." ${ }^{.50}$ Hampstead Garden Suburb was designed to bring slum-dwellers closer to nature with all its beauties, and to offer them a plot of land to supplement their incomes. The physical labour in private gardens was supposed to improve the health and physique of the nation's poor. It also aimed at re-creating the tight social network connected in many people's minds with the image of the old rural village.

In 1904, the Hampstead Garden Suburb Trust, of which she was a leading member, acquired 240 acres at Hampstead Heath in order to transplant the idea of the model village along the lines of precedents such as Bournville or Port Sunlight into the city. The recent extension of the underground to Golder's Green had opened up the hitherto remote area for urban development. By 1908, the scheme of the Hampstead Garden Suburb was well under way with the architects Unwin and Parker building the first houses and streets in a manner carefully planned by the Trust members. The new homes filled quickly with tenants from the middle and upper reaches of the metropolitan working classes as well as with members of the better-off sections of society who felt attracted by the natural beauty of the location. Ironically in view of the social reformist character of the original settlement, in today's London, Hampstead Garden Suburb caters mainly for house-owners of

\footnotetext{
${ }_{538}$ Barnett, Samuel Augustus and Henrietta Octavia Rowland Barnett, Towards Social Reform, 1909, p.149

539 Barnett, Samuel Augustus and Henrietta Octavia Rowland Barnett, Towards Social Reform, 1909, p.171

${ }^{540}$ Barnett, Henrietta Octavia Rowland, Science and City Suburbs, 1906, p.73
} 
wealthy middle-class origins or above. Constantine II, the last king of Greece, is among the residents, as is TV-presenter Jonathan Ross.

During her stay at Whitechapel, Barnett had come to realise the importance of housing in social reform. "A very short study of town life is enough to show that the dwellings of the people is one cause from which follows health or disease, happiness or misery, strength or weakness" ${ }^{241}$, she wrote in her article on Science and City Suburbs. The eugenicist Francis Galton, she related, had once suggested a study to see under which conditions gifted families arose and prospered most frequently. She demanded a similar study "showing the conditions under which have most frequently arisen the lazy, the vicious, the hopeless, the degraded, and the unemployable"542. She felt sure that such a study would immediately point to the deplorable state of slum tenements and the airless, lightless, spaceless set-up of poor neighbourhoods. The housing of the people, she held, was largely accountable for the evils - spiritual as well as physical - from which modern society suffered. "How can people persist in striving after the realisation of the spiritual life", she asked, "how can they rest in the knowledge of God when the normal decencies are denied to them, when their bodies are deprived of oxygen and their minds crushed by sordid surroundings?" 543 Children grew up in these neighbourhoods surrounded by vice and temptation and familiarised with evil from early childhood. Adults lost the remnants of dignity, faith and conscience when all they saw was misery and crime.

Barnett quoted data gathered by the Medical Officer of Health at Finsbury, Dr. Newman, to illustrate the direct relation between the size of a tenement and the death rate. She cited his findings that for every one death in a three-room dwelling, three people died in a home of but one room. While the overall infant mortality for England and Wales in 1906 was 196 children below the age of one in every 1000, in industrial Burnley, for instance, it was 229 in every 1000. And not only the high mortality alarmed Barnett. "Where the death-rate is high, there the vitality is low", she concluded from the data available to her. "The people are tired, hopeless, fearful of adventuring either for work or for pleasure, disinclined to put forth effort, (...) falling into drunkenness, not so much from wilful wickedness as from dreariness, finding it (...) the cheapest method of escaping from the depressing influences of great cities and the unlovely barrack boxes or dirty alleys in which are situated the homes of the poor." ${ }^{\prime 54}$

A series of physical examinations in conjunction with the Boer War had shown, she recounted, that out of 3000 potential recruits from industrial neighbourhoods, only about 1000 proved fit for

\footnotetext{
${ }^{541}$ Barnett, Henrietta Octavia Rowland, Science and City Suburbs, 1906, p.46

542 Barnett, Henrietta Octavia Rowland, Science and City Suburbs, 1906, p.48

543 Barnett, Henrietta Octavia Rowland, Science and City Suburbs, 1906, p.48

${ }_{544}$ Barnett, Henrietta Octavia Rowland, Science and City Suburbs, 1906, p.50f.
} 
service in the army. She contrasted these results with observations from rural areas such as Craven in Yorkshire or the country parts of Cheshire to find that there, a much larger proportion of tall and strong men could be found than in Manchester, Liverpool, Sheffield, Birmingham or London. Town influences, Barnett believed, had brought many into the ranks of the unemployed because they were unemployable; and they would remain thus unless they were taken "one by one" and "by good air, regular food, firm discipline, and patient friendship lifted on to the plane from which they can survey themselves as clothed in self-respect" ${ }^{\prime 545}$.

Despite her critical appraisal of town life, however, unlike Booth, Barnett did not seek to undo recent social and economic developments. Rather, she adapted the myth of the countryside to accommodate the realities of industrialised England. Although she embraced many of the objects and beliefs of the back-to-the-land movement, she did not hold that the solution lay in a return to the romanticised ideal of the pre-industrial country village. The Industrial Revolution constituted a fact which could not be reversed; nor should it be undone, in Barnett's view. She firmly believed that industrialisation constituted a step forward in the history of mankind and therefore approached its side-effects of urbanisation and rural de-population with pragmatism. In Barnett's eyes, the best way to deal with these developments in the set-up of society was to eliminate their evil consequences and to maximise the benefits. Among the many possible tasks suggesting themselves to the social reformer, by 1904, town planning took precedence in Barnett's mind as one of the most urgent as well as promising areas of activity. She believed that urban growth required careful planning and the input of modern science, medical, technical and social, in order to avoid the mistakes made in the past. "Cities must grow", she proclaimed. "The progress of mankind is from the Garden of Eden to the City of God." ${ }^{546}$ Barnett hoped to redirect urban growth in a way that their citizens may have both the inspiration of the garden and the stimulus of a living urban community. In the idea of a Garden Suburb she saw an ideal combination of countryside and towndwelling.

One of the objects of the Hampstead Garden Suburb Trust was to put within reach of a $2 \mathrm{~d}$ fare from their respective places of work cottages with gardens at affordable rents for working men and their families. The Trust took care to avoid overcrowding by designing comparatively generous cottages of three to five rooms per family. The gardens, Barnett believed, would prove an economic asset to the occupants. Experience in George Cadbury's model village at Bournville had shown that an eighth of an acre of gardened land provided an average yield of fruit and vegetables of about 1s 11d a week ${ }^{547}$. Barnett welcomed the prospect of healthful recreation which working in the garden

\footnotetext{
545 Barnett, Henrietta Octavia Rowland, Science and City Suburbs, 1906, p.52

546 Barnett, Henrietta Octavia Rowland, Science and City Suburbs, 1906, p.74

547 Barnett, Henrietta Octavia Rowland, Science and City Suburbs, 1906, p.63
} 
would provide for the industrial population. It was for the children in particular that she rejoiced in the idea of a garden. Dirty, stunted and ill-nourished, playing in littered and noisy streets, they suffered from a neglect of mind and body, she felt, which would backfire in their adult years when physical and mental strength would prove vital to their sustenance ${ }^{548}$. "In imagination - let us transplant those children into a garden", she suggested, "father working, mother watching, children helping, the land yielding with that generosity which under any climate seems to follow spade labour and personal interest. ${ }^{" 549}$ Barnett anticipated countless benefits from such an arrangement; the pennies, she believed, would no longer be needed for sweets as the gooseberries were enjoyed, relish and pickles would give way to vegetables, lettuce and fruit; most of all, the family would be able to take its pleasure together - the pleasure of tending to and watching over a garden and its returns produced by personal labour and physical effort ${ }^{550}$.

Barnett hoped that in cleaner, spacious and well-aired neighbourhoods with private gardens attached to every cottage, the people would develop a sense of home life and an interest in nature which, she believed, formed the best securities against the temptations of drink and gambling ${ }^{551}$. A paddling pond, play grounds, possibly a tennis court, public baths and other joint amenities would greatly contribute to the inhabitants' quality of life and provide opportunities for healthful pastimes and physical and mental restitution. "The health, the vigour and the alertness which wholesome recreation in the fresh air engenders are unattainable by town-livers, who indifferent to, because ignorant of, what they have lost, are content to be 'like beasts with lower pleasures, like beasts with lower pains'",552, Barnett advertised the advantages of her plan.

Barnett took pains to emphasise that Hampstead Garden Suburb was not intended as a philanthropic scheme. With the settlement, she hoped to return to a natural social community which the division into segregated neighbourhoods had destroyed. "It is the essence of the scheme", she wrote, "that 'all sorts and conditions of men' should find homes in the suburb." ${ }^{\circ 53}$ About a third of the 240 acres at hand was set aside for middle-class dwellings, and some of the best spots on the Heath reserved for mansions and villas of an annual rent of $£ 100$ or more. Slightly inflated rents on more desirable habitations, the Trust calculated, would help to pay for the roughly seventy acres designated to house the working classes. ${ }^{554}$ All inhabitants would share the church, the chapel, the public library, the lecture hall and the open space built into the settlement "not by forced, artificial methods, but as

\footnotetext{
${ }_{548}$ Barnett, Henrietta Octavia Rowland, Science and City Suburbs, 1906, p.64

549 Barnett, Henrietta Octavia Rowland, Science and City Suburbs, 1906, p.65f.

${ }_{550}$ Barnett, Henrietta Octavia Rowland, Science and City Suburbs, 1906, p.65

551 Barnett, Henrietta Octavia Rowland, Science and City Suburbs, 1906, p.57

${ }_{552}$ Barnett, Henrietta Octavia Rowland, Science and City Suburbs, 1906, p.57

553 Barnett, Henrietta Octavia Rowland, Science and City Suburbs, 1906, p.69

554 Barnett, Henrietta Octavia Rowland, Science and City Suburbs, 1906, p.71
} 
inhabitants" ${ }^{\prime 55}$ of the same suburb. These joint institutions might, Barnett hoped, bring members of all classes together on a regular, possibly even daily, basis and produce shared memories which constituted the backbone of any living community. A common interest in gardening and "a love of flowers and fruit and growing" 556 would bind them even further together and help break down the misunderstandings and misgivings between the various classes.

Barnett took her commitment to social variety very seriously. As part of the Garden Suburb, she planned dwellings for single working women and widows. She envisaged non-charitable alms houses for the aged poor where, equipped with a small pension or supported by their children, they might pass their remaining days not in the closed quarters of a workhouse, but in lovely surroundings "where they can see the sunset and hear the birds sing" 557 . "There will be", she wrote, 'the convalescent home, the co-operative rest-house, the training school and the working lads' hostel - for a community should bear the needy and handicapped in daily mind." ${ }^{558}$ She dreamed of a community where the better-off would not close their eyes against suffering and want and where the poor would be given a chance to rise to their highest selves.

Poverty, Barnett came to see in the course of her social commitment, was a problem which affected the individual as well as the community. Any solution to the problem of pauperism thus had to take into account the many facets, personal, cultural and economic, of destitution. Barnett proposed to meet the challenge by approaching the problem on various levels. Personal help and friendship between members of different classes alongside providing the means for self-enlargement and education would help the individual poor to find a new sense of self and to make the most of his or her resources. But there existed conditions which stood in the way of improvement which were beyond the influence of the individual and needed to be addressed by the community at large. Society, Barnett had come to accept, had a very real interest in the alleviation of poverty. It cost the community dearly, in terms of both financial as well as social and cultural resources.

In the next chapter, I look at the social thought of Percy Alden who explored the national dimensions, repercussions and costs to the community of the problem of mass unemployment.

\footnotetext{
555 Barnett, Henrietta Octavia Rowland, Science and City Suburbs, 1906, p.58

556 Barnett, Henrietta Octavia Rowland, Science and City Suburbs, 1906, p.63

557 Barnett, Henrietta Octavia Rowland, Science and City Suburbs, 1906, p.70

558 Barnett, Samuel Augustus and Henrietta Octavia Rowland Barnett, Towards Social Reform, 1909, p.341
} 


\section{B. Socialist Christians}

\section{Chapter 5 - Percy Alden and Poverty as a Complex National Question}

\section{Biographical Data: Percy Alden}

Among the social reformers featured in the present study, Percy Alden was the religious thinker who least resorted to the aspects of individual dignity and humanity as an argument for social reform. He justified his social endeavours first and foremost with the economic loss accruing to the community through poverty. The belief in the absolute value of humanity which inspired Headlam and Booth to campaign for social reconstruction occurred in Alden's political and economic expositions only as a side-line. Alden perceived the working man and woman as persons with rights and needs which had to be taken care of in the course of social reform. But public action and public expenditure in the fight against poverty, Alden believed, were best justified through the immense gain the community should expect from the alleviation of destitution.

The Congregationalist Percy Alden worked as founder warden of Mansfield House in Canning Town (1891), the first university settlement of his denomination. Born in 1865, Alden received his education at Balliol College, Oxford. During his time at university, he found himself deeply influenced by the Idealist philosopher T. H. Green, whose thought exerted a strong influence over many religious socialists, among them, for example, Henry Scott Holland and Charles Gore, the editors of the theological compilation Lux Mundi and founders of the Anglican Christian Social Union. From Green, Alden took over the idea that being part of a social community obliged the individual to a life of active citizenship, of service to the community and its members. After graduation in 1888, Alden joined Mansfield College, the recently established Congregationalist theological college at Oxford, with the aim of becoming a minister. In 1891, he went down to West Ham in the East End of London in order to take up office as warden of Mansfield House, the Congregationalist pendant to the settlement house Toynbee Hall, without finishing his course. Alden 
remained in his post for ten years until 1901. His withdrawal from office as warden of Mansfield House may have been linked to the fact that at the time, he converted to Quakerism ${ }^{559}$.

His most distinctive contribution, not only to Mansfield House, but to the history of the settlement movement, was the degree to which Alden interwove the institution and its residents with municipal politics. He himself acted as borough councillor for West Ham from 1892 until the end of his residency at Mansfield House, as well as functioning as deputy mayor for Newham in 1894. He encouraged his fellow-residents to stand for local school boards, the borough council and municipal office, and to work as Poor Law Guardians or sanitary inspectors in the area. After standing down as full-time warden of the settlement house, Alden edited the liberal daily paper The Echo. Already a member of the Fabian Society, he joined the Rainbow Circle in 1903 where he gave papers, among other issues, on local governance and the housing question ${ }^{560}$. Alden entered Parliament as a Lib-Lab candidate in 1906, retaining his seat until 1918. In 1919, he left the Liberal Party to join Labour.

Politically, the Dictionary of Labour Biography describes Alden as a "radically-minded liberal" His greatest interest lay with the problem of unemployment. During his period at Mansfield House he conducted a local survey into unemployment, its causes and effects, in collaboration with local trade unions, the ILP and the SDF. The survey showed that of the 10.000 men and women out of work in West Ham in 1894, nine-tenth belonged to the group of unskilled or casual labourers ${ }^{562}$. Alden strongly believed that the state had a duty towards those out of work for no fault of their own and he thus campaigned for labour exchanges, public works, labour colonies and state subsidies to insurance schemes run by trade unions. His approach to the problem gained distinction through his interest in and detailed study of foreign attempts at solving unemployment such as the Ghent system of unemployment insurance or the German network of labour exchanges.

Alden was closely associated with a number of Nonconformist Christian Socialist organisations such as the interdenominational Christian Socialist League, the Christian Social Brotherhood and the Socialist Quaker Society ${ }^{563}$. But unlike Stewart Headlam or William Booth, he did not resort to theology or his personal faith as frames of reference to justify his proposals in his social and political writings under discussion in this thesis. To an even stronger degree than Henrietta Barnett, Alden represented the type of Christian thinker who felt moved by the religious impulse towards

\footnotetext{
559 Curthoys, Mark C.und Tim Wales, Oxford Dictionary of National Biography, 2004

560 Freeden, Michael, Minutes of the Rainbow Circle, 1989; see e. g. Meeting 146, May $4^{\text {th }}, 1910$ and Meeting 180 , Oct. $8^{\text {Th }}, 1913$

${ }^{561}$ Bellamy, Joyce Margaret and John Saville, Dictionary of labour biography, 1976

${ }_{562}$ Harris, Jose, Unemployment and politics, 1972, p.89

563 Jones, Peter d'Alroy, The Christian socialist revival 1877 - 1914. Religion, class, and social conscience in lateVictorian England, 1968, p.335
} 
social reform while not excluding secular sources of inspiration, such as the systems in operation in other countries, for finding solutions to specific problems.

Percy Alden was killed in his home in London during an air raid in 1944.

\section{Poverty - A National Question}

The idea which dominated Alden's social thought was his firm conviction that poverty was a problem of national dimensions, caused by flaws in the social, political and economic set-up. Underneath his analysis of the social problem lay the notion that as such, poverty also merited a national effort towards solution.

Alden's was a novel interpretation of poverty. Much more radically still than Henrietta Barnett, Alden made a clean break with the widespread Victorian view, propagated for instance by the Charity Organisation Society, that poverty was largely a personal problem, a state which had in many cases been brought about by the individual him- or herself through moral weakness and personal failure. Nor did he share the COS doctrine that the individual should be compelled to bear the consequences of poverty by way of punishment for his or her character shortcomings. In his writings, Alden set out to identify the impersonal, economic and social factors which he held responsible for the surge in unemployment and the existence of mass poverty.

Alden argued that it was maldistribution, not a shortage of resources, which forced so many to live in poverty. There existed enough wealth in the UK; but it spread unfairly, among individuals and families as well as between neighbourhoods and geographic regions. Like Headlam and Barnett, he pointed to the present contrast between great riches and abject poverty. "In our haste to become rich and powerful", Alden wrote, "we have forgotten that if the increase in our material wealth is not accompanied by a corresponding increase in the well-being of the working-classes, that if we are neglecting the underfed children of the towns living amidst unhealthy and degrading conditions, we are thereby rearing a mighty edifice upon insecure foundations. ${ }^{" 564} \mathrm{He}$ criticised the approach of traditional political economists who measured a nation's wealth in absolute figures and neglected the issue of distribution. In Alden's eyes, a nation's standing and power could only meaningfully be measured in terms of the standard of living enjoyed by the majority of the population and here,

\footnotetext{
${ }^{564}$ Alden, Percy and Charles F. G. Masterman, Democratic England, 1912, p.29
} 
Britain failed miserably ${ }^{565}$.

Alden stressed that the maldistribution of means in his opinion resulted not from some failure of the concerned individuals or districts, but from faults in the social and industrial organisation. He heavily criticised the practice of heaving responsibility for the poor upon the district authorities and local Poor Law agencies neither of which possessed the jurisdictions necessary to cut at the roots of the problem of poverty. The practice put thickly populated areas under unbearable stress in times of severe trade depression without a chance to either prevent or alleviate the situation. Alden illustrated his point with the example of West Ham which through its geographical position and the presence of the docks was forced to accommodate migrants from the overcrowded and povertystricken neighbourhoods of East London as well as the inflow of agricultural labourers and unskilled workers from the provinces. "Wherever unskilled labour is required in large quantities, and especially where casual labour is employed, a rather low type and quality of men will be attracted", Alden stated; "but to say that West Ham is responsible for such a situation is really to make it responsible for the whole industrial system for which West Ham is only a type." ${ }^{\circ 66}$

Only in a concerted national effort, Alden believed, could Britain hope to get the problem of poverty under control, and control it she must, if she was to keep her position at the forefront of the nations. He called for a mobilisation of "all the forces of our civilisation" 567 to create for every inhabitant of Great Britain down to the destitute slum dweller such an environment as would make them fit to play their part as citizens of the British empire. "It is the first duty of the State, as also its highest and truest interest, to set on foot such constructive reforms as will check the wholesale demoralisation of large sections of the working classes, and restore to the people the assurance so long denied that honest work will carry with it a just and certain reward"568, Alden propounded.

Two issues which stood at the core of Alden's social interest shall in the following analysis serve to illustrate Alden's point on the national repercussions of poverty and the need for concerted nationwide action: unemployment and the problem of housing.

\footnotetext{
565 Alden, Percy and Charles F. G. Masterman, Democratic England, 1912, p.27

566 Alden, Percy, TheUnemployed. A National Question, 1905, p.102

567 Alden, Percy and Charles F. G. Masterman, Democratic England, 1912, p.29

568 Alden, Percy, TheUnemployed. A National Question, 1905, p.144
} 


\section{Unemployment: Its Causes and Cures}

a) Unemployment as a Negative Side-Effect of Industrialisation and the Consequent Need for State Action

In 1905, Percy Alden published an extensive analysis of the causes and types of unemployment and of possible remedies for its most devastating effects. The book bore his central argument as a title: The Unemployed. A National Question.

Alden began his text by observing that all great manufacturing countries experienced periods of trade depression, more or less severe, with a consequent increase in the number of the jobless. Mass unemployment constituted an almost inevitable side-effect of industrialisation, he argued. "The problem of the unemployed is the problem of all civilised communities", he wrote, "and (...) because it is chiefly found in manufacturing countries affected by the 'industrial revolution' it seems to point to some radical defect in our social system, a lack of ability to organise and coordinate the wealth-producing power of the country." $" 569$

With his interpretation of unemployment as a negative side-effect of industrialisation Alden went against established economic doctrine which thought that a sound economy relied upon a pool of surplus "hands" at the disposal of industry to fill in in times of high demand. Alden stressed that on the contrary, unemployment was neither desirable nor necessary for a strong economy. Unemployment, he held, constituted a real loss to the community. He estimated that in any one average year, no less than six percent of the manual workers found themselves without a job. Their labour, he argued, was irretrievably lost to the nation.

Nor did Alden believe it essential to a stable economy to leave men to fight for their own interests. He pointed out that the occurrence of mass unemployment in all industrialised nations disproved the doctrine that the deserving, honest and hard-working were sure to find jobs. The market could not, he emphasised, be depended upon to provide for the willing and able-bodied worker, as experience had shown. ${ }^{570}$ Alden also criticised the provisions of the Poor Law for those who could not sustain themselves through their labour: those provisions were neither restorative nor preventive and in their present form tended to aggravate the problem by rendering many of the paupers unemployable in the long run. Alden stressed that in a modern industrialised society, unemployment constituted a

\footnotetext{
569 Alden, Percy and Charles F. G. Masterman, Democratic England, 1912, p.87. The idea that poverty and unemployment are necessary corrolaries of civilisation recurs for instance in the thought of John Mackinnon Robertson which will be discussed in some detail in Chapter Eight of this thesis.

570 Alden, Percy, TheUnemployed. A National Question, 1905, p.3
} 
far more complex problem than fathomed by classical political economists and that the existing instruments for dealing with its consequences were ineffectual.

Alden warned that he did not in his book offer an easy panacea. He stressed that no single measure of legislation and political intervention could serve to eliminate the fact of unemployment. In his opinion, unemployment was the result of some deep-seated structural defects in the economic and social set-up of Britain. In the long run, he believed, only "such reconstruction and reorganisation of society as will give prominence to the ethical and cooperative rather than the competitive factors in our national life" could eliminate at least some of the factors causing trade depression and ensure steady employment for all ${ }^{571}$. What could, however, be cured through immediate legislative intervention, he encouraged his readers, was the suffering of those hit most severely by the instability of trade and the cyclical scarcity of jobs and in his book he set out to provide a catalogue of measures to do it.

For Alden, the need and justification for governmental intervention was undisputed. To check the negative effects of unemployment, he stressed, lay in the interest of the entire nation: through proactive intervention, the community must try to limit the loss to the nation and maintain those out of work in a state of industrial efficiency. "The community", Alden held, "is responsible for the unemployed, and therefore the very essence of the question is that there should be Government action and Government intervention." ${ }^{572}$ In his book The Unemployed. A National Question Alden thus concentrated on measures which could be undertaken by the state and the municipalities to reduce the adverse effects of the cyclical development of trade and to provide a certain degree of stability and security to its working population.

b) Some Factors Underlying the Cyclical Development of Trade and Industry

Countering the opinion that unemployment was frequently a consequence of failure on the part of the individual, Alden began his treatise with an analysis of the factors which to his knowledge and understanding determined the ups and downs in a nation's industry. He took pains to emphasise that many of these factors lay beyond the control of either individual or even the community. He pointed out that the radical changes in the set-up of industry and commerce in the first half of the nineteenth century, for instance, had caused an upheaval in the labour market. "The complete change in the conditions of manufacture from industries carried on in the homes of the people often in small 
villages, to a factory system with all accompanying evils", he wrote, "together with the decline of agriculture as a profitable industry, must be regarded as the main causes of the growth of the unemployed problem." $" 573$

Mass urbanisation played a part in the genesis of the problem of unemployment. Alden explained how the concentration of large numbers of workers in the towns had brought fierce competition for the limited amount of work available in any one industrial centre. Alden estimated that during the past forty years, the number of those engaged in agriculture had declined by almost fifty percent, while the urban population had grown rapidly. At the time of his writing, roughly seventy percent of the population of the United Kingdom lived in cities and towns. Alden counted 244 new urban districts which had sprung up between 1881 and $1901^{574}$.

Changes in the methods of production also accounted for a considerable amount of cyclical unemployment. The introduction of labour saving machinery repeatedly dislocated myriads of workers with each new level of efficiency and optimisation reached in the apparatus. Competition between manufacturers for cheap and efficient production made it difficult "for any except the young, the active and the skilled" to count on regular and continuous work. In times of severe depression, however, skill, too, had its downsides. The highly specialised processes of production which often required special training made it difficult for workers in one trade to fill a possible vacuum in another. Men out of work in the London building trades, Alden argued, clearly could not supply vacant places in the textile trades of Lancashire. Alden denounced the imperfect mobility of labour in Great Britain which in his mind contrasted unfavourably with the adaptability of employers as well as employed in, for instance, the United States ${ }^{575}$.

Other factors upsetting the delicate balance of trade were purely accidental. The weather, for instance, often forced certain trades into periods of inactivity. Storms and floods sometimes prevented raw materials from reaching the factories; severe cold or heat made the carrying on of work impossible as, for example, in the building trade. Alden cited an inquiry of a House of Commons Committee on Distress from Want of Employment conducted in 1895 which went to show that in that year, in 454 localities in Britain affecting a population of approximately 10 million persons, there was an exceptional degree of want of employment due solely to the severity of the winter $^{576}$. Political events, too, could impact upon trade and industry. The year 1903, for example, had seen a dramatic increase in the number of the unemployed as the masses of now jobless reservists and volunteer forces returned from the Boer War ${ }^{577}$.

\footnotetext{
573 Alden, Percy, TheUnemployed. A National Question, 1905, p.2

574 Alden, Percy and Edward Hayward, Housing, 1907, p. 27

575 Alden, Percy and Charles F. G. Masterman, Democratic England, 1912, p.94

576 Alden, Percy, TheUnemployed. A National Question, 1905, p.11f.

577 Alden, Percy, TheUnemployed. A National Question, 1905, p.13
} 
On the whole, Alden pointed out, the laws which governed the workings of industry and commerce were still largely unknown even to specialists. Economic scientists found themselves at a loss when trying to explain the mechanisms of the market and could agree only on rather rudimentary or fragmentary ideas. "We have not yet been able to ascertain what it is that lies at the root of the great fluctuations in trade," he noted, "the periods of boom and the periods of depression, although the cause is probably inherent in the competitive system, but we do know that a considerable amount of dislocation is caused by the maladjustment of supply and demand." ${ }^{, 578}$

As varied as the factors involved in the rise and fall of unemployment, Alden believed, were the men and women hit by the lack of employment. Alden called for a very careful assessment of the problem of work and the lack thereof. He warned against oversimplifying the problem by lumping together all the jobless poor in an depiction of laziness and immorality. In the second part of his book, Alden therefore attempted a classification of the unemployed according to the causes which underlay the loss of their jobs and to offer supportive measures modelled on their particular situations.

\section{Unemployment: The Need for Classification}

To offer them the help they needed and to deal effectively with the social consequences of unemployment, Alden argued that one had to distinguish between various types of jobless. In his book, he made out four categories of unemployed whose prospects of finding new employment differed depending on their levels of skill and the reasons for their loss of work. For each category, Alden developed a different list of measures which could be undertaken by the authorities to support them until they could be re-absorbed into the labour market.

a) The Unemployable and the Unemployed

The first category which in his book he kept separate from the others was made up of the "baser kind" 579 of the unemployable. "We must differentiate between the genuine unemployed man who is

578 Alden, Percy and Charles F. G. Masterman, Democratic England, 1912, p.94

579 Alden, Percy, TheUnemployed. A National Question, 1905, p.28. Note here the similarity of argument with William Booth. 
in search of work, and the vicious vagrant who is in search of opportunities for plunder" 580 , he warned. The latter kind existed, he conceded to those who held fast to the view of unemployment as a moral question, and some of them indeed constituted a danger to all peaceful citizens and a useless drain upon the funds of the community. Yet, Alden subdivided this class into two very different groups which merited very different treatment.

The first subgroup was made up of individuals who bore no responsibility for their state. Alden was prepared to make every allowance for instance for the physically and mentally impaired, children, the very old and, an inclusion reminiscent of William Booth, the "weak-willed inebriate" 581 . He held that the community bore a responsibility for instance towards the aged as "worn-out veterans of industry"582; a society which did not care for its elderly must, Alden believed, not only be unethical in character, but unstable in its very set-up ${ }^{583}$. The physically or mentally disabled as persons "stricken by the hand of God" 584 were equally entitled to maintenance at the public expense. Alden cited the example of Pastor von Bodelschwingh's homes for the physically and mentally maimed at Bielefeld in Germany as an example to show how those guiltlessly unemployable could be offered humane and merciful treatment in lieu of the punitive provisions of the workhouse ${ }^{585}$.

The other group of unemployables, the "criminals, semi-criminals, vicious vagabonds and the incorrigibly lazy; in a word, all able-bodied men who refuse work, or [were] refused work, owing to defect in character"586, constituted a different matter in Alden's eyes. He blamed them for giving unemployment as a whole a bad name as a parasitic existence. He recommended to treat them with strictness and severity and to deal with them as vigorously as one would with an infectious disease. It is interesting to note here that the idea of work-shyness as an infectious disease also occurred in William Booth's exposition in In Darkest England. Both thinkers recommended detaining such men and women in labour colonies in order to avoid cross-contamination of those willing to work. They hoped to benefit the unemployable, firstly, through a change of environment, by removing them from temptation and supervising their conduct in and outside working hours; and secondly, by setting them to useful and humanising work, whether it be in farming or manufacture ${ }^{587}$.

Like Booth, however, Alden was prepared to temper judgement with mercy even in the cases of the „culpably“ unemployable; the dividing line between unemployment and unemployability was, after all, fluctuating, he acknowledged. All too often, unemployability was itself the product of long-term

\footnotetext{
580 Alden, Percy, TheUnemployed. A National Question, 1905, p.18

581 Alden, Percy, TheUnemployed. A National Question, 1905, p.17

582 Alden, Percy, TheUnemployed. A National Question, 1905, p.29

583 Alden, Percy and Charles F. G. Masterman, Democratic England, 1912, p.144

584 Alden, Percy, TheUnemployed. A National Question, 1905, p.30

585 Alden, Percy, TheUnemployed. A National Question, 1905, p.30

${ }_{586}$ Alden, Percy, TheUnemployed. A National Question, 1905, p.17

587 Alden, Percy, TheUnemployed. A National Question, 1905, p.27
} 
unemployment. Alden pointed to the "process of demoralisation" $" 588$ and to the degeneration in physical strength and efficiency which almost inevitably accompanied extended periods of joblessness. Unemployment and inefficiency, he claimed, were related as closely as poverty and drink $^{589}$. "It is widely felt", he wrote, "that such men are not altogether to blame if as a result of disorganisation in our social system they become ineffective factors in the work of production." 590 Measures employed to deal with them should therefore with all due severity and strictness be restorative rather than punitive in character. Even the lowest of the unemployable, Alden believed, could not be dismissed as altogether hopeless. Many were men of weak character, easily swayed and led by temptation. As Booth had done, Alden urged society to offer them a chance at recuperation: "Just as we manufacture criminals and create the unemployable, by our stupid and shortsighted methods, so, by a systematic and sustained effort, we may perhaps be able to save a minority of these men from themselves and transform them into useful citizens."591 Alden emphasised that there should be the possibility for inmates of labour colonies, through good work and impeccable conduct, to graduate into higher classes of detention camps, gradually working their own way out of the category of the unemployable. In his belief in the reformability of even the most degraded Alden resembled the attitude of the other Christian thinkers under scrutiny here.

But besides the unemployable, some of whom were indeed vicious, lazy, semi-criminal, Alden reminded his readers that there existed the much larger group of the genuine unemployed which consisted of willing workers unable through no fault of their own to find a job. In opposition to classical political economists, Alden defined unemployment as "the labour that might be utilised in the production of wealth, that is not so utilised for one cause or another, and is therefore wasted" ${ }^{\prime 592}$. The genuine unemployed Alden divided into three categories. The first class comprised men and women without a job because of dislocations in trade, the death of a trade or changes in methods of industry which rendered a certain part of the workforce unnecessary. The second class consisted of those unemployed owing to a temporary depression in trade or a severe winter. The third category was made up of casual or seasonal workers without a job. Alden designed the categories to include both skilled and unskilled workers and to be purposely broad in character.

For each group, as we have heard above, Alden suggested a separate set of measures modelled on the causes of their distress. However, he also identified certain general measures which he hoped would help to alleviate the hardship of all those concerned. In a preliminary chapter to his more detailed treatment of the various categories of the genuine unemployed he gave a summary of them.

\footnotetext{
${ }_{588}$ Alden, Percy, TheUnemployed. A National Question, 1905, p.7

589 Alden, Percy, TheUnemployed. A National Question, 1905, p.6 f.

590 Alden, Percy, TheUnemployed. A National Question, 1905, p.16

591 Alden, Percy and Charles F. G. Masterman, Democratic England, 1912, p.92

592 Alden, Percy, TheUnemployed. A National Question, 1905, p.32
} 
b) Effective Trades Organisation, Education and the Revival of Agriculture: Some General Steps in the Fight Against Unemployment

Some measures in Alden's catalogue of immediately implementable reforms were designed to benefit all classes of labourers. As a first step, he called for better organisational structures for dealing with issues of industry and commerce as they affected the working population. First and foremost, Alden postulated that the communal responsibility for unemployment be recognised through the appointment of a Minister of Commerce and Industry and the formation of a central government department concerned with all questions relating to labour. At present, he pointed out, with the Home Office, the Local Government Board and the Board of Trade, three separate departments of state were concerned with issues of employment. In addition, the Commissioners of Woods and Forests and the Board of Agriculture were involved with matters relating to rural industry ${ }^{593}$. The resulting scattering of authority and jurisdiction, Alden argued, stood in the way of an effective long-term solution to the social and economic loss caused to the nation by unemployment. "If this is a national question", he demanded, "a special minister at the head of a special department should have the responsibility placed upon him of dealing with it." 594

The new central agency should then go about growing a network of regional and local nerve centres. Alden suggested that as one of the first measures the new department set up in every town and city a local labour bureau, managed by a joint committee representing the district council, the employers and the trades unions. The bureau would serve, he envisaged, as a centre of registration for those seeking labourers as well as for those seeking jobs. He pointed to existing bureaux such as those run by the Salvation Army which had already successfully put the idea into practice. Alden hoped to lift the concept of labour registries onto a national level. He also planned to commission them to collect data on the situation of industry and commerce for use by the government.

Alden cited the German example of municipal labour registries ${ }^{595}$. There, the individual offices linked up for an exchange of information and the collection of statistical data. Through their networking, the bureaux managed to extend the area of potential employment to neighbouring districts and could thus place workers in situations which the labourers would not have found if left to their own devices. Alden ascribed a success rate of 57 percent to the German bureaux for the placement of skilled male unemployeds ${ }^{596}$. He proposed to make registration with such bureaux compulsory throughout England. Alden expected a positive side-effect to such universal recording.

\footnotetext{
593 Alden, Percy, TheUnemployed. A National Question, 1905, p.41f.

594 Alden, Percy, TheUnemployed. A National Question, 1905, p.137

595 Alden, Percy, TheUnemployed. A National Question, 1905, p.48ff.

596 Alden, Percy, TheUnemployed. A National Question, 1905, p.51
} 
It would, he hoped, help to identify the work-shy and incorrigible idler who could then be dealt with by the authorities. ${ }^{597}$

A reform in the system of taxation, too, might help to boost industry and to alleviate the problem of unemployment, Alden envisaged. He quoted the economist J. A. Hobson to the effect that fluctuations in trade and industry could in part be traced back to underconsumption ${ }^{598}$. According to Hobson, in all highly developed countries, consumption failed to keep pace with production. Large incomes were being capitalised and reinvested at so rapid a rate, Alden reported on the theory, that the demands of ordinary consumption were unable to proceed pari passu with the production that resulted. The practice was especially problematic in the case of so-called unearned incomes from inflated rents which tended to have no equivalent value in material resources. Underconsumption was further aggravated by the fact that the mass of population lacked the means necessary to buy even a modicum of industrial produce. Alden argued in favour of redistributive taxation upon large incomes, unearned increment and big monopolies, in order to re-arrange the nation's wealth and thus to spread the power to consume among a larger portion of the population ${ }^{599}$.

Most urgently, to secure the labourer's spending powers in times of need and to keep him in a state of health and efficiency, Alden campaigned for an extension of insurance against unemployment. At present, insurance schemes were run only on a semi-voluntary basis by some of the trade unions. Alden counted about two hundred unions, chiefly in the skilled industries of engineering, iron, shipbuilding and the printing trades which gave unemployed benefit. The figures obtained from these unions indicated for Alden a growing need for insurance. While according to a table included in The Unemployed. A National Question, in 1899, the unions paid out a total of $£ 187.332$ to jobless members, the amount almost tripled to $£ 504.214$ in $1903^{600}$. In Alden's eyes, the need called for an organised effort for a large-scale insurance scheme on a national level.

Alden pointed once again to continental Europe where insurance schemes with governmental involvement had already proved successful in the fight against poverty. He cited the example of two municipal funds in Cologne and Leipzig in Germany, instituted in 1896 and 1903 respectively. With the assistance of the local labour registry, Alden reported, the cities provided insurance against unemployment for male workers in the winter months. For a premium of between $3 \mathrm{~d}$ and $5 \mathrm{~d}$ per week, the unemployed received a daily amount of $2 \mathrm{~d}$ for eight weeks in all. A grant by the municipality which matched the subscriptions raised from members helped to finance the scheme ${ }^{601}$. In Switzerland, Berne and Basle ran schemes on a semi-voluntary basis, involving the

\footnotetext{
597 Alden, Percy, TheUnemployed. A National Question, 1905, p.54

598 Alden, Percy, TheUnemployed. A National Question, 1905, p.38

599 Alden, Percy, TheUnemployed. A National Question, 1905, p.38

${ }^{600}$ Alden, Percy, TheUnemployed. A National Question, 1905, p.59

${ }^{601}$ Alden, Percy, TheUnemployed. A National Question, 1905, p.61
} 
municipalities, trades unions and the canton. In Belgium, Ghent maintained a scheme to which members and local authorities contributed in equal proportions. In France, the central government had in 1904 adopted a policy of making grants in assistance of funds already established by trades unions and voluntary societies. ${ }^{602}$ It was the principle of proportionate contributions from state and individual which Alden wanted to adopt for a national insurance programme in Great Britain. „If the subsidies were made proportionate in some way to the contributions of the trade unions“, he envisaged, ,it would certainly have the effect of stimulating fresh interest in this form of insurance." ${ }^{\prime 03}$

In addition to a Ministry of Commerce, tax reform and extensive insurance programmes, like the other thinkers examined so far, Alden recommended improved education and technical training as safeguards against joblessness. He pointed to the large percentage of unskilled labourers (a figure he estimated at almost 50 percent) among the present unemployed in England to emphasise the need for more thorough technical instruction. Already, certain trades which demanded high levels of skill and inventiveness had began to migrate to countries with better educational facilities. "The importance of education is so fully recognised on the Continent", he asserted, "and the opportunities are so much more numerous, that the English workman frequently finds himself handicapped in the competitive race." ${ }^{\circ 04}$

Alden also hoped to reduce unemployment by stopping new workers from migrating from the country into the city ${ }^{605}$. He urged his readers to make country life "both possible and pleasurable" 606 by way of new houses and improved infrastructure, better provisions for old age and above all, in accordance with the contemporary craze for gardening and agriculture as a panacea against poverty, by "affording ample facilities for obtaining small holdings" ${ }^{\text {607 }}$. In Denmark, Alden reported from his extensive continental experience, five-sixths of the arable land were occupied by peasants with small holdings ${ }^{608}$. In England, the land monopoly stood in the way of small-scale farmers and dairy co-operatives which would provide rural workers with an opportunity to support themselves and their families. Alden applauded pilot schemes in England along lines similar to the Danish model such as the Lincolnshire and Norfolk Small Holdings Association and recommended following their example on a large scale.

\footnotetext{
${ }^{602}$ Alden, Percy, TheUnemployed. A National Question, 1905, p.62ff.

${ }^{603}$ Alden, Percy, TheUnemployed. A National Question, 1905, p.65

${ }^{604}$ Alden, Percy, TheUnemployed. A National Question, 1905, p.36

${ }^{605}$ Alden, Percy, TheUnemployed. A National Question, 1905, p.35

606 Alden, Percy, TheUnemployed. A National Question, 1905, p.35; see also Alden, Percy and Charles F. G. Masterman, Democratic England, 1912, p.263

${ }^{607}$ Alden, Percy, TheUnemployed. A National Question, 1905, p.35

${ }^{608}$ Alden, Percy, TheUnemployed. A National Question, 1905, p.39
} 


\section{c) Labour Colonies}

One of the main planks of Alden's reform programme were labour colonies. Like his propagation of small holding schemes, it tied in firmly with the back-to-the-land movement. His campaign for a return to a strong agricultural sector in the nation's economy and his vision of a nation-wide network of labour colonies to re-acquaint the jobless with the land are highly reminiscent of William Booth's proposal for farm colonies as laid out in In Darkest England. But by contrast to William Booth, Alden believed that such colonies should be run not by voluntary associations or religious bodies, but by local authorities and the central government as part of a concerted offensive against unemployment.

Alden was convinced that careful selection and classification of the colonists was an essential prerequisite to the success of such a scheme. He believed that only through the control of a central agency could they be upheld. To illustrate his point, Alden cited the German colonies which had failed to introduce an effective system of selection and accepted all types of unemployed from the work-shy to the able-bodied worker onto the same farm. The Germans did not realise that the lower type tended to bring the colony as such into disrepute. As a result, the able-bodied willing worker often found it difficult to gain employment directly from the colony, he warned.

The criminal and idle tended to feed off the labour of the honest unemployed, often lowering the colony's efficiency below breakeven point ${ }^{609}$. In Alden's opinion, it was the main problem faced also by William Booth's farm colony at Hadleigh. Many of the men who frequented the Salvation Army shelters in London and were then sent to the country hovered on the borderline to unemployability ${ }^{610}$. Alden believed that it was impossible to deal adequately with the criminal, the drunkard and the genuine unemployed in one single colony, and it were invariably the few capable and willing workers who came off worst. "What is required", Alden urged, "is that the State and the local authority should attempt what every employer does for himself every day, distinguish between men of good and bad character."

As an example of successful selectivity Alden pointed to the Poor Law Farm of the Poplar Union ${ }^{612}$. Erected in 1904 upon 100 acres of land at Dunton, near Laindon in Essex, it housed one hundred men carefully chosen from among the inmates of the Poplar workhouse. An eight hours day left time for leisure pursuits such as reading, handicraft or games. An allowance of $1 \frac{1}{2}$ ounces of tobacco per week was made to each worker and the food rations were liberal. The work on the land

\footnotetext{
${ }^{609}$ Alden, Percy, TheUnemployed. A National Question, 1905, p.123

${ }^{610}$ Alden, Percy, TheUnemployed. A National Question, 1905, p.72

611 Alden, Percy, TheUnemployed. A National Question, 1905, p.133

612 Alden, Percy, TheUnemployed. A National Question, 1905, p.114
} 
and the entire atmosphere were meant to be restorative and to put the unemployed into a position to care for themselves. The experiment was, Alden admitted, still very young at the time of publication of The Unemployed. A National Question; but it seemed to him "to point to the fact that if the best of the able-bodied inmates of the workhouse could be selected there [is] no real reason why they should not be made at least partially self-supporting upon similar farm colonies throughout the country and eventually fitted to take up the work of agriculture" ${ }^{" 13}$. West Ham, too, he reported, was in the process of conducting negotiations about erecting a similar farm under the auspices of its Poor Law Union ${ }^{614}$.

Interestingly, although Alden sought alternatives to Poor Law treatment for the unemployed, unlike Barnett he was not interested in reforming the Poor Law itself or to remove its penal associations. On the contrary, he welcomed the punitive character of Poor Law treatment in dealing with the „culpably“ unemployed and planned to entrust the Poor Law authorities with the running of colonies for the criminal and vagabond. Yet, for the type above this class, for those who ran the risk of being pauperised by casual employment and long spells of enforced inactivity, Alden wanted the borough councils to take over. For them, he feared the stigma of the Poor Law and demanded restorative rather than punitive treatment. The colonies for the casually employed would in Alden's vision be considered a testing ground and offer an introduction to country life from which, if showing themselves capable and willing, inmates could move on to a higher grade colony run by municipalities and county councils.

The municipal and county-run colonies would have as their special objects "the establishing of the unemployed upon the land"615 and the men selected would already have some knowledge of agriculture. The colony of this grade could also, Alden envisaged, serve as a training school for agricultural skills. In collaboration with it could be run a small holding scheme to which colonists who had passed the training and the test of character could eventually move. With the system of graded colonies, Alden hoped to provide the unemployed in whatever state of pauperism and disillusion with a "ladder at his feet" ${ }^{\prime 616}$ to win his way back to independence and dignity. The cost of such a scheme, Alden envisaged, would be much lighter than the costs of the present Poor Law system.

\footnotetext{
${ }^{613}$ Alden, Percy, TheUnemployed. A National Question, 1905, p.114

614 Alden, Percy, TheUnemployed. A National Question, 1905, p.114

615 Alden, Percy, TheUnemployed. A National Question, 1905, p.125

${ }^{616}$ Alden, Percy, TheUnemployed. A National Question, 1905, p.126
} 
d) Measures Aiming at Specific Forms of Unemployment

Alden followed his proposals for general measures with specialised catalogues designed to fit the needs of his three categories of the genuine unemployed.

Workers unemployed owing to dislocations of trade, the death of a trade or changes in the methods of industry formed the first of those classes. Such men and women, Alden observed, were usually unskilled or below the highest standard of efficiency, often already past the prime of life. They had little chance of finding new employment in their own or some other established trade. As most promising measures in support of such unemployeds Alden therefore propagated the creation of fresh industries, the revival of agriculture, a reduction in the hours of labour and, as a final resort, emigration in order to help them ${ }^{617}$.

Among this class of unemployed Alden detected a large proportion of workers who had once been agricultural labourers. Such men could be transferred almost immediately back to the country, Alden envisaged, where they would be placed on county council farm colonies or be given land under a system of cooperative small holdings along the lines of the Danish model mentioned above $^{618}$. Some carefully selected town-bred men could also, Alden anticipated, benefit from such a scheme if they were first introduced to the essentials of farming and life-stock rearing in agricultural training schools and special training colonies. The Dutch, Alden reported, ran successful programmes for educating town-bred men in the ways of country life at their colonies at Frederiksoord, Willemsoord and Wilhelminasoord. Nearly 3000 men and women, unemployed industrial workers from Amsterdam, Rotterdam and The Hague, had already passed the training courses and been permanently established upon the land, Alden reported.

Germany, too, possessed a system of farm colonies, although they were used primarily for the detention and rehabilitation of the work-shy. Alden expected to considerably lighten the burden on the public purse by putting the unemployed to useful work. "If the German labour colonies, made up of criminals, semi-criminal, inebriates, and a rather poor class of middle-aged unemployed, with only a sprinkling of strong, able-bodied industrious men, can produce the results to be seen at Luhlerheim, near Wesel (...)", he reasoned, "it ought not to be difficult after eliminating every bad element and selecting only the men who are both capable and willing, to make such training schools largely self-supporting."

Alden proposed to supplement the idea of farm colonies by the creation of new branches of industry as, for instance, through afforestation programmes. The advantages of afforestation, Alden believed,

\footnotetext{
${ }^{617}$ Alden, Percy, TheUnemployed. A National Question, 1905, p.67

${ }^{618}$ Alden, Percy, TheUnemployed. A National Question, 1905, p.72

619 Alden, Percy, TheUnemployed. A National Question, 1905, p.76
} 
were two-fold. Firstly, it would save the nation from having to import its timber and thus keep capital worth about $£ 20.000 .000$ within the country ${ }^{620}$. Secondly, once established in Britain, the timber industry would provide many jobs for skilled as well as unskilled workers all year round. In Germany, Alden reported, at least 400.000 men were employed in forestry, and a large number of men and women were dependent upon subsidiary trades. At least thirteen million acres of waste land, Alden calculated, could profitably be re-afforested in the United Kingdom, much of it in Scotland and Ireland, but also in Wales and Northern England.

Alden cited the example of the German Erzgebirge in Saxony to show that land not worth more than $4 \mathrm{~s}$ per acre per annum for agricultural or pastoral purposes could give net receipts of $38 \mathrm{~s}$ per annum when re-afforested ${ }^{621}$. Alden anticipated a myriad of positive side-effects from the planting of woodland. It would "undoubtedly develop other industries, improve the climate, protect mountain land from the denudation of soil and by arresting the rainfall gradually transform its character" ${ }^{\prime 622}$. He pointed out that the idea of re-afforestation was already put into practice on a small scale in Liverpool, where 470 acres had been planted with 162.000 trees in five years at Vyrnwy. The city authorities reported that not only had the programme been a success in terms of creating jobs, but that the trees purified the water and thus provided better quality drinking water in the town ${ }^{623}$.

Alden also listed a reduction in the hours of labour in certain trades as a means to create new jobs for those out of work who fell into this category. Apart from re-absorbing some of the presently unemployed, Alden also expected that reducing hours of work would impact favourably on the question of efficiency. In some trades, Alden pointed out for his readers, the introduction of an eight hours day had markedly improved the quality of work and amount of produce per week. "The best workers", Alden wrote, "are the men who take some pleasure in their work, and this is impossible if the number of hours worked is altogether unreasonable." ${ }^{624}$ By way of a pilot scheme, he suggested to try reducing the hours of work in all transport industries under public control. A considerable proportion of the unemployed might, he speculated, be given jobs if carmen, bus and tram men, and indeed all municipal employees, worked from eight to ten instead of the customary fourteen to sixteen hours a day ${ }^{625}$. The London County Council had shown in a pioneering effort that by shortening the hours of men employed on the tramways under public control in 1899 and 1900, it could increase its staff by nineteen percent while at the same time also considerably increasing its

\footnotetext{
${ }^{620}$ Alden, Percy, TheUnemployed. A National Question, 1905, p.82

${ }^{621}$ Alden, Percy, TheUnemployed. A National Question, 1905, p.79

${ }^{622}$ Alden, Percy, TheUnemployed. A National Question, 1905, p.80

${ }^{623}$ Alden, Percy, TheUnemployed. A National Question, 1905, p.82

${ }^{624}$ Alden, Percy, TheUnemployed. A National Question, 1905, p.84

${ }^{625}$ Alden, Percy, TheUnemployed. A National Question, 1905, p.84
} 
profits. Such reduction created more jobs, better service and higher profits and turned out to be to the advantage of all parties involved.

Emigration could in Alden's eyes only constitute a very last resort in the category of those who had lost their jobs owing to dislocations of trade or changes in the methods of industry. Here, he differed from William Booth who made large-scale emigration an integral part of his social scheme. For the individual with proper training and under governmental guidance, Alden conceded, emigration could be a potent remedy against unemployment. But, he calculated, with the same amount of expenditure both in time and money needed to send an emigrè to the Canadian plains, a man with some knowledge in agriculture could successfully be established upon a small holding in England. All too often, emigration meant a real loss to the community. "The very best of her sons" left the country, Alden explained, "while the worst, whom the colonies are not willing to receive, should be left upon our hands" ${ }^{\prime 626}$. Alden considered a man's labour to be capital which should, if at all possible, be invested at home. Sending able-bodied men abroad amounted in his eyes to handing resources over to foreign industries without hope of return. Alden held that such practice ran counter to England's best interests as leading industrial nation.

The unemployed of the second category, those who found themselves without a job owing to temporary depression in trade or to severe weather during the winter months, did not require permanent tending by the state. Alden explained that they could be helped quite effectively by offering them temporary employment in municipal relief works and short-term stays upon governmental farm colonies. For municipal relief works, Alden recommended to save jobs which could easily be done in times of distress. He had in mind any form of public improvement which could be carried out without "interfering in any way with regular work and the ordinary conditions of trade" ${ }^{627}$. He stressed that such works must not be punitive or used as a "test of character" as done under the Poor Law, but that an adequate wage must be paid in return for honest labour ${ }^{628}$. Lastly, Alden insisted that the work had to carry real benefits for the community providing it.

One area apt for municipal works was in Alden's eyes the reclamation of waste lands such as the low-lying tidal lands along the estuaries of Britain's many rivers or the land near the sea coasts in counties like Essex. Alden recounted how the Dutch government had successfully reclaimed the Zuyder Zee, a total of 476.000 acres. The undertaking had cost the government $£ 18$ per acre and it was now selling the land for $£ 89$ per acre. In England, too, small portions of land had already been reclaimed such as some areas along the Wash and in the East Fen. "The land reclaimed", Alden enthused, "which was formerly washed by the sea at every tide, is now covered with rich corn-fields

\footnotetext{
${ }^{626}$ Alden, Percy, TheUnemployed. A National Question, 1905, p.86

627 Alden, Percy, TheUnemployed. A National Question, 1905, p.92ff.

628 Alden, Percy, TheUnemployed. A National Question, 1905, p.92
} 
and comfortable farmsteads." ${ }^{629}$ Alden proposed the improvement of the Port of London as a suitable pioneering project. " $[\mathrm{N}] \mathrm{o}$ one doubts the importance of improving the Port of London, which might be the finest in the world,“ he wrote, ,nor does anyone question the fact that a large amount of unskilled labour might well be employed in giving increased facilities to shipping, in improving the navigability of the Channel and beautifying the banks of the River Thames." ${ }^{\circ 30}$

In an equal manner, an immense amount of local work could be done in the improvement of canals. Alden proposed for the government to nationalise all 4000 miles of inland water ways in order to encourage the use of those "great public highways" while affording at the same time an outlet for unemployed labour. Once again, Alden lamented the backwardness of Great Britain: "As compared with the Continent", he warned, "we are sadly lacking in enterprise, for it is no uncommon thing to find in Holland or Germany that the canals take boats up to 1000 tons, while in England, the great majority of the canals will only accommodate barges from 18 to 60 tons." 631 The deepening, broadening and improvement of the canals had the advantage that it could be done in instalments, taking one section of a river at a time, and could thus be saved for periods of acute distress amongst the industrial population. Other possibilities for public relief works could be found on sewage farms, in laying out open spaces, recreation grounds and new cemeteries, in cleansing and paving streets, or in making footpaths.

Alden's third category of unemployed, those whose labour was seasonal or casual, presented by far the most difficult, but also the most pressing problem to the social reformer. "Seasonal and casual labour, however beneficial to individual employers, is detrimental to the best interests of the community as a whole" ${ }^{932}$, Alden believed.

Alden proposed to attack seasonal and casual unemployment through organisation. He detected the most striking example of labour of the above kind at the docks where a hitherto unregulated army of men competed against each other for the limited amount of work on offer. Alden estimated that there were about 22.000 dockers in East London alone, about 5000 of whom were unemployed on any one given day. A central authority regulating all the docks and taking on all workers "as far down as Tilbury" would, he believed, "no doubt eliminate much of this surplus labour and free it to seek other employment" ${ }^{\prime 63}$. In other trades, the local labour bureaux which Alden proposed to introduce as local nerve centres of the new Ministry of Commerce and Industry could take on the task of regulating the respective labour markets, especially if they joined in a national network of exchange. At the same time, organisation of the workers themselves in some form of trades unions

\footnotetext{
${ }^{629}$ Alden, Percy, TheUnemployed. A National Question, 1905, p.88

${ }^{630}$ Alden, Percy, TheUnemployed. A National Question, 1905, p.90

631 Alden, Percy, TheUnemployed. A National Question, 1905, p.92

632 Alden, Percy, TheUnemployed. A National Question, 1905, p.121

633 Alden, Percy, TheUnemployed. A National Question, 1905, p.116
} 
could help to prevent sweating ${ }^{634}$, and to obtain a certain measure of job security. Only through the power of collective bargaining could the individual worker hope to achieve stability in terms of wages as well as employment, Alden pointed out; disorganisation and fierce competition among the workers played into the hands of the capitalist and contributed to the problem of unemployment. ${ }^{635}$ Alden suggested to supplement the organisation of labour and the labour market with measures such as vacant lot cultivation and allotments to cover periods of enforced idleness. Alden envisioned a colony of dockers within easy reach of the dock which provided each man with his own small holding. In their leisure time, these men would cultivate their plot of land and grow fruit and vegetables for their own consumption. "They would thus be saved from the demoralising conditions which seem to attend casual dock labour", Alden enthused, "and at the same time be adding to their scanty earnings." $" 636$

For those seasonal or casual labourers who could not be provided with a garden or small holding, Alden recommended additional employment in home industries as he had encountered during his continental travels. In the provinces of Moscow in Russia, Alden had counted forty-three categories of cottage industries. These trades were carried on by Russian peasants whenever their main employment as farmers allowed ${ }^{637}$. Alden estimated the annual value of these industries at about $£ 5.000 .000$. The German region of Wurttemberg, too, served Alden as a striking example of the positive effects of home industries. Trades like blanket making, carpet making, paper making, wood carving and a myriad of other crafts were carried on by the German peasants in their leisure time, the produce being exported even to England ${ }^{638}$. Alden believed that great results could be obtained through home employment without any excessive interference with the ordinary course of trade and industry.

\section{Housing: The National Repercussions of Destitute Housing}

The other aspect of the social problem at the core of Alden's social and political thought was the question of housing. He believed that like unemployment the housing situation was a direct result of the recent changes in the economic set-up of the nation. The mass migration of rural labourers to the

\footnotetext{
634 Alden, Percy and Charles F. G. Masterman, Democratic England, 1912, p.67

${ }^{635}$ Alden, Percy and Charles F. G. Masterman, Democratic England, 1912, p.73

${ }^{636}$ Alden, Percy, TheUnemployed. A National Question, 1905, p.117

637 Alden, Percy, TheUnemployed. A National Question, 1905, p.120

638 Alden, Percy, TheUnemployed. A National Question, 1905, p.120
} 
urbanities in search of industrial employment in the first half of the nineteenth century had strained the towns to their very limits, in terms of space as much as in terms of their mechanisms for accommodating and integrating the newcomers. Alden found in the way people lived one of the clearest indicators of their relative wealth or poverty. In his eyes, the hovels and dens of the very poor were as much the symptoms as they were causes of the social disease. He considered it a truism to say that unhealthy houses and unsanitary surroundings were unfavourable to the growth of healthy and virtuous citizens ${ }^{639}$. "Pauperism and crime, drunkenness, physical degeneration, disease and high death rates are all bound up with the problem of housing" ${ }^{640}$, Alden wrote in his book Housing which he published co-jointly with the housing reformer Edward Hayward in 1907. In Alden's opinion, housing constituted one of the most pressing issues on the agenda of the social reformer. Solving it, Alden hoped, would enable society to attack with more confidence and hope of success all attending marks of poverty.

\section{a) The Problem of Overcrowding}

The most obvious and urgent aspect of the disastrous state of housing was in Alden's eyes the problem of overcrowding. At the time of his writing Alden estimated that about eight percent of the entire British population lived under overcrowded conditions; of the inhabitants of London, it was almost two-thirds. Alden differentiated between two aspects of the phenomenon: the crowding of a flat where too many people lived to a room and the crowding of a given area, where too many houses huddled together on too little ground. The Model Bye-Laws of the Local Government Board, Alden reported, required four hundred cubic feet of air for every person over ten years of age living in a given tenement. Army regulations insisted on six hundred cubic feet in barracks and the Poor Law on five hundred cubic feet of air per inmate of a workhouse or frequenter of a casual ward. In the slum areas of the big industrial cities this standard was most certainly never met ${ }^{641}$. Lack of breathing space in the tenements was made worse by the sheer mass of houses in some neighbourhoods. Alden held that no city could be in a properly healthy condition which had more than twenty-five people to the acre ${ }^{642}$. York, Alden cited Seebohm Rowntree's report, had an average population of 20.5 persons per acre; yet, the city sported areas where the ratio rose to as much as 349 people to the acre. In London, one could find areas such as Lewisham and Hampstead with a

\footnotetext{
639 Alden, Percy and Edward Hayward, Housing, 1907, p.1f

${ }^{640}$ Alden, Percy, TheUnemployed. A National Question, 1905, p.168

${ }^{641}$ Alden, Percy and Edward Hayward, Housing, 1907, p.53f.

${ }^{642}$ Alden, Percy and Edward Hayward, Housing, 1907, p.5
} 
comparatively agreeable 18.1 and 36.1 inhabitants per acre. Industrial districts such as Shoreditch and Paddington showed a ratio of 180.2 and 106.1 persons per acre respectively.

Alden identified two factors which contributed to the catastrophic housing situation. Firstly, a serious house famine prevailed throughout Britain. In both countryside and towns, he pointed out, there existed too few houses to accommodate the entire population at a comfortable standard. Consequently, several families often had to cram into a single tenement which had been designed for far fewer inhabitants. The self-regulating forces of laissez-faire had failed in the area of housing, Alden held. Private enterprise had not kept pace with the need for accommodation and Alden was not surprised by that. The prices for land and for building materials made it almost impossible to build good quality tenements which the average working man receiving no more than a subsistence wage could afford ${ }^{643}$.

The second factor which contributed to the problem of housing were the exorbitant rents in cities and industrial centres. Scarcity of supply naturally meant monopoly value and exaggerated rents were the result. In central London, a single room cost an average rent of $6 \mathrm{~s} 6 \mathrm{~d}$ per week, while in suburban London, a tenement of three rooms could be obtained for $7 \mathrm{~s} 6 \mathrm{~d}$ per week ${ }^{644}$. The scarcity of adequate accommodation and the high rents thus bore down most heavily upon those who had no choice, for reasons inherent in their jobs or for lack of means of transport, but to live close to their places of work right in the centre of town. But the problem of housing affected all labouring sections of society, not only the worst-off strata, Alden pointed out. Competition for accommodation in the lower categories inevitably spoilt the supply in the higher ${ }^{645}$.

b) The Costs to the Community of Unhealthy Housing and the Need for Concerted Action

Bad housing seriously affected the health, bodily strength and moral character of the inhabitants, Alden argued. It was an ascertained fact, he insisted, that the greater the density of population the higher was the death rate in that area. In Finsbury, Alden quoted the same statistics by the Medical Officer of Health as did Henrietta Barnett, mortality varied in exact proportion to the number of rooms in the tenement, the death-rate in one-room flats being as high as 39 , in four-room tenements only about 6 per thousand. ${ }^{646}$ The increase in the death-rate in overpopulated areas showed up particularly clearly in the case of infant mortality. In 1905, 219 children under the age of five per

${ }^{643}$ Alden, Percy and Edward Hayward, Housing, 1907, p.8

644 Alden, Percy and Edward Hayward, Housing, 1907, p.6

${ }_{645}$ Alden, Percy and Edward Hayward, Housing, 1907, p.49

${ }^{646}$ Alden, Percy and Edward Hayward, Housing, 1907, p.63 
thousand births died in tenements of one room, while in flats of four rooms or more, the death rate was 99 per thousand. Alden explained that the contrast was particularly striking when the death was caused by zymotic diseases like diarrhoea. Here, in one-room tenements, mortality with a rate of 53 children per thousand was almost three times as high as in four-room flats with a rate of 19 per thousand ${ }^{647}$.

Nor were death and disease the only negative effects of inadequate housing. Alden impressed upon his readers that the destitute tenements of the poor cost the nation dearly. Like Barnett, Alden pointed to the general low vitality of those who inhabited overcrowded dwellings which translated into a loss of efficiency in labour and took a heavy toll on the community. He quoted the Royal Commission on Labour to show that the average workman and working woman lost about twenty days in the year from simple exhaustion ${ }^{648}$. Children born into a slum environment with its lack of fresh air and sunlight, its dirt, illness and indecency, Alden warned, would inevitably grow up physically and morally degenerate and fail to become dutiful citizens of the British Empire and efficient contributors to the national wealth ${ }^{649}$.

Alden feared that bad housing impacted on the state of civilisation in Great Britain. In terms of sociability, slum dwellers could not be expected to learn the basics of cleanliness and respectability, he argued, in surroundings where twenty or thirty houses shared a single water supply. Nor did they get a chance to develop a proper understanding of moral propriety when members of several families were forced to live, eat and sleep in a single room ${ }^{650}$. "Why all this terrible, yet preventible waste of human material, waste of energy, waste of health, physical and moral, and waste of life itself?" ${ }^{651}$ Alden asked. The deplorable state of housing endangered Britain's "position in the forefront of the nations" ${ }^{\prime 652}$.

As in the case of unemployment, Alden impressed upon his readers the need for concerted public action to remedy the situation and to reduce the negative effects of bad housing on the nation as a whole. The growth of the towns must not, he impressed upon his readers in his book Democratic England, be left to chance and private speculators. The city authorities who in Alden's eyes should have taken on responsibility for town planning and building regulations had so far failed to institute some form of effective control over the growth of new districts and neighbourhoods. "We have forgotten how to live in the country", Alden formulated, "and we have not yet learnt how to live in

\footnotetext{
${ }_{647}$ Alden, Percy and Edward Hayward, Housing, 1907, p.63ff

648 Alden, Percy and Edward Hayward, Housing, 1907, p.66

${ }^{649}$ Alden, Percy and Charles F. G. Masterman, Democratic England, 1912, p.34

${ }^{650}$ Alden, Percy and Edward Hayward, Housing, 1907, p.59ff

651 Alden, Percy and Edward Hayward, Housing, 1907, p.66

${ }^{652}$ Alden, Percy and Edward Hayward, Housing, 1907, p.153
} 
the town, and meanwhile our towns and cities are growing with immense rapidity." ${ }^{953}$ For better or worse, he pressed on, Britain's future lay in her industrial centres and it was high time for the authorities to take in hand the matter of town planning in order to reduce to a minimum the attendant evils of city life ${ }^{654}$.

c) Tax Reform, Town Planning and Municipal Housing Schemes: Alden's Solution

Alden saw no alternative to a concerted nationwide plan of action. He conceded that there existed some private and semi-private enterprises in housing which pointed in the right direction and could give important impetus to the public agent. Alden named Octavia Hill's system of personal inspection where lady visitors checked regularly on the occupants' situation as an example which recognised the landlord's special responsibilities as well as unique powers which he ought to exercise in the best interests of his tenants. He listed George Cadbury's model village at Bournville near Birmingham and the Lever Brother's model dwellings at Port Sunlight both of which managed to combine the requirements of an industrialised economy with the advantages of life in the countryside. Alden also mentioned the Garden City Movement as "a movement which seeks to make us ashamed of our ugly, unhealthy cities and to advance principles by which the worst evils may be altogether abolished, or at least reduced to a minimum, in the planning of new cities." ${ }^{955} \mathrm{He}$ applauded the movement's insistence upon town-planning and -control. These examples demonstrated in Alden's opinion that housing reform paid off for both parties involved. "Those responsible for these schemes assure us", Alden reported, "that not only is a reasonable return made upon the large outlay of capital necessary, but that they are otherwise thoroughly paying concerns in the increased vigour, happiness and general efficiency of the workers whom they seek to benefit." ${ }^{656}$ Ultimately, however, Alden believed that the housing problem could be solved only by way of municipal schemes and state intervention. Alden detected hopeful beginnings in recent political action: the problem of slum housing had been on the agenda of Parliament at least since the institution of the Royal Commission on Housing in 1884. Alden applauded the resultant Housing Act of 1890 which put the local authorities into a position to conduct sanitary inspections in private houses and to close down or demolish houses or blocks which did not meet the required standard of health and safety ${ }^{657}$. The same Act conferred onto the municipalities the power to purchase land

\footnotetext{
${ }^{653}$ Alden, Percy and Edward Hayward, Housing, 1907, p.48

${ }^{654}$ Alden, Percy and Charles F. G. Masterman, Democratic England, 1912, p.192ff

${ }^{655}$ Alden, Percy and Edward Hayward, Housing, 1907, p.119

656 Alden, Percy and Edward Hayward, Housing, 1907, p.68

657 Alden, Percy and Edward Hayward, Housing, 1907, p.19
} 
outside its own immediate boundaries, and to erect tenements to house its population, a valuable instrument for overcrowded districts.

But other recently employed measures such as slum clearance appeared to him to be misguided. Alden mentioned the example of Boundary Street, Bethnal Green, where the London County Council had cleared fifteen acres of slum between 1893 and 1897, affecting almost 6000 inhabitants; they had replaced the insanitary houses by healthy, airy, well-lit and well-built tenements for about 5000 people ${ }^{658}$. The London County Council advertised its actions as a success claiming that the death rate and infant mortality in the area had dropped by half. Similar schemes, Alden reported, had been executed at Clare Market and St. Pancras, as well as in other great industrial centres such as Manchester, Birmingham, Leeds and Edinburgh. Yet, in Alden's eyes, slum clearance constituted a deficient means of solving the problem of housing. "The truth is that the slum dwelling is a malignant social disease and its poisonous roots lie deeper than is generally recognised in the body politic", Alden held. "We cannot cure this disease by merely removing some of its deadly plague spots." ${ }^{659}$

Slum clearance was neither economical nor effective, he argued. The cost of clearance schemes appeared to him excessively high. The Boundary Street clearance had cost the public $£ 280.000$, the local authorities had paid $£ 32.000$ per acre for the land alone ${ }^{660}$. Alden also pointed out that the people who moved into the new, healthy and comfortable dwellings were not usually those who had been dishomed by the clearance because rents tended to rise beyond the means of the original slum dwellers. The destitute population of areas such as Boundary Street or Clare Market was simply driven into other parts of the city to form new slum areas or aggravate the overcrowding in existing slums. Slum clearance increased the competition for the lowest category of housing and thus forced up rents in other poor neighbourhoods.

Alden proposed to cut at the roots of the housing situation by way of legislative reform. He suggested to start with a reform of local rates. The increasing charge of rates imposed by local taxation constituted one of the chief factors forcing up rents in the cities. Alden estimated that at the time of his writing between twenty and forty percent of the total rent had to be paid in rates to the local authorities. They fell most heavily on those who could least afford it, those who were forced to live right in the centre of town close to their places of work. Alden proposed a lean version of the land reform scheme propagated, for instance, by Stewart Headlam. He supported proposals forwarded by members of the London County Council to replace the present rates on houses and site improvements with a rate charged upon the sites themselves by local government.

\footnotetext{
658 Alden, Percy and Edward Hayward, Housing, 1907, p.77

659 Alden, Percy and Edward Hayward, Housing, 1907, p.79

${ }^{660}$ Alden, Percy and Edward Hayward, Housing, 1907, p.77
} 
Like Headlam, Alden hoped that land which the owner had kept vacant in expectation of a rise in its value would through the new system be forced into the market and that unoccupied houses be filled with tenants. In addition to the new system of local rates, he recommended to levy a national tax on the unearned increment of urban property whenever it was sold or re-leased. "It is the locality that has created the increased value", Alden wrote, "why then should not the locality reap some return in the form of rates from such values?" ${ }^{661}$ Alden hoped to distribute the burden of rates more fairly upon the shoulders of both, tenants as well as landlords. "Property is no longer to have an undue claim", Alden postulated; "great wealth must be prepared to bear burdens in the interest of the whole community. ${ }^{\circ 62}$ Like many New Liberals, he believed in property not as an absolute right, but as a trust to be used to the good of the nation.

In addition to legislative reform, Alden advocated municipal housing schemes. "The larger the city, the more varied its needs, the more highly industrialised its trade, the more necessary it is that the local authority should step in (...) to protect the individual" ${ }^{663}$, Alden stated. Regulations and interventionism by the local authority had already become common place in some sections of city life he countered opponents of government interference: the municipality constituted one of the greatest employers of labour in the country, running services such as gas and water supply, electricity, public libraries or transport. Alden proposed to extend municipal control to the area of housing. The Housing Act of 1890 had laid the legal foundations for this. Alden refuted arguments brought forward by supporters of laissez faire that building activities by the municipality would deal a serious blow to the builders as a class. He pointed to the immense and urgent need for accommodation, particularly in the cities which, he believed, left plenty of room for both private and municipal enterprise. The municipality would fill in for those sections of society for which private enterprise had hitherto failed to provide adequate housing.

Nor would municipal housing constitute a "sectional benefit" for one class of citizens only ${ }^{664}$. Far from conferring an exclusive advantage upon the working classes, the removal of slum areas would contribute immensely to the general level of public health and also help to beautify the cities. Besides, housing for the lowest category of tenants tended to relieve the pressure higher up the scale, reducing rents and lessening overcrowding. Municipal estates, Alden believed, could serve as examples of decent, cheap and well-built houses helping to raise also the standard of tenements built by private landowners. ${ }^{665}$

True to his faith in the beneficial effects of agriculture and gardening which had already led him to

\footnotetext{
${ }_{661}$ Alden, Percy and Edward Hayward, Housing, 1907, p.92

${ }^{662}$ Alden, Percy and Charles F. G. Masterman, Democratic England, 1912, p.7

${ }_{663}$ Alden, Percy and Charles F. G. Masterman, Democratic England, 1912, p.193

664 Alden, Percy and Edward Hayward, Housing, 1907, p.110ff

665 Alden, Percy and Charles F. G. Masterman, Democratic England, 1912, p.205
} 
advocate small holding schemes and farm colonies, Alden also propagated the planning of new suburbs in easy reach from the centre of town to be inhabited by the working classes in a vein reminiscent of Barnett's ideas. Alden expected several advantages from such new settlements. He argued that the lower prices of land outside the boundaries of the inner city made the building of sound, but affordable houses possible and resulted directly in lower rents. Alden contrasted the London County Council housing scheme at the inner city Bourne Estate at Holborn, which had cost the ratepayer $£ 60$ net loss per head rehoused with a housing experiment at suburban Tooting which he reported to be entirely self-supporting. "The cost of land and of building on the Bourne Estate per three-roomed tenement is $£ 76112$ s 6d, as compared with $£ 26310$ s 0d on the Tooting Estate," Alden listed. "What further illustration is required to show the impossibility of rehousing in the central area?"'666

Apart from affordable land, Alden pointed out, the suburbs also offered enough space for gardens and well-sized courtyards attached to every tenement. "The garden in which actual personal work can be done in the evening and on holidays, is the most restful of all places" ${ }^{\$ 67}$, Alden enthused. In unison with Henrietta Barnett, he envisaged physically strong fathers, relaxed mothers and healthy, happy children thanks to the singular supply of fresh air, sunlight, food and physical exertion offered by the private garden. Every thousand pounds spent on the preventive measure of planning and developing a suburb, Alden reckoned, would be of more value than ten times that amount spent on slum clearance at the centre of town.

For these and other measures of town planning to be effective, Alden believed that a new administrative machinery had to be created to deal with the whole of the districts around each large town. At present, the area directly adjoining the London County Council, for instance, fell under the jurisdiction of forty different local authorities. They could not be expected to act with the unanimity of purpose required in so important a matter as the growth and development of the metropolis. Alden demanded that this new centralised authority should have extensive powers of land purchase outside its own immediate area so that "development may be along the lines of a definite policy of enlargement and improvement" ${ }^{668}$ Alden listed the example of the German towns of Cologne, Dusseldorf and Ulm where such powers had been used to the permanent benefit of the cities. "This is where Port Sunlight, Bournville and 'Garden City' have pioneered the way in the matter of town planning”, Alden explained. "All our large cities must, sooner or later, follow their example." One important step to be coordinated by the new administrative machineries was, Alden suggested,

\footnotetext{
${ }^{666}$ Alden, Percy and Edward Hayward, Housing, 1907, p.138

${ }^{667}$ Alden, Percy and Edward Hayward, Housing, 1907, p.132

${ }^{668}$ Alden, Percy and Edward Hayward, Housing, 1907, p.83

${ }^{669}$ Alden, Percy and Edward Hayward, Housing, 1907, p.83
} 
the extension of public transport to these new suburbs. An industrial city, he believed, tended to grow along economic lines, with production and commerce focusing on the centre of town and living quarters for the majority of population moving to the outskirts. If left to private enterprise, the means of transit tended not to grow with equal rapidity. "If an industrial city with a huge aggregation of population is to be healthy", Alden held, "the centrifugal force should be equal to the centripetal. ${ }^{~} 670$ It was in his opinion the responsibility of the city authorities to ensure the possibility of transit for the workforce from their homes to their places of work. In a very large number of cases, Alden argued, it was not necessary for the worker to live near his place of work. Provided that accommodation was affordable and the means of transit fast and cheap, a very large proportion of the working classes could easily be housed in estates outside the centre of town. Alden illustrated his point by citing the example of Edmonton which had witnessed an explosive growth of population from 14.000 to 62.000 when workmen's trains were instituted. Walthamstow likewise grew from 11.000 to 95.000 with the provision of cheap and rapid means of transit. Overall, with the institution of affordable means of transport, Inner London had lost 494.000 persons between 1891 and 1901, Middle London had gained 195.000 people, and Outer London had grown by 1.200.000 new inhabitants ${ }^{671}$.

In this matter, too, Alden took pains to emphasise that the community could expect fiscal gain on top of the benefits in terms of national health, industrial efficiency and urban beautification accruing from an improved housing situation. Experience taught that municipal electric tramways paid, he wrote. In the year 1908/09, the net profits from the Birmingham street railways, for instance, amounted to $£ 35.000$. The combined municipal tramways of England and Wales carried 1.991.143.430 passengers at an average fare of 1.04 penny per mile in the years of 1907 and 1908 . The total capital invested ran to $£ 44.920 .000$, the operations producing a net revenue of $£ 3.288 .000^{672}$. Since 1894,175 local authorities had successfully municipalised their street railways, the private competitors diminishing in size and capacity. Alden recommended to widen the potential margin of profits for the municipalities by enabling local authorities to purchase cheap land along proposed new railroad lines beforehand, thus making the routes a good investment. Existing roads from the outskirts to the city centre should be broadened wherever possible, and new highways be constructed so as to allow for fast electric trams without interfering with ordinary vehicular traffic. To carry out those schemes, Alden postulated that a special authority be instituted, a local Traffic Board dealing with all questions of transport ${ }^{673}$.

\footnotetext{
670 Alden, Percy and Edward Hayward, Housing, 1907, p.134

${ }^{671}$ Alden, Percy and Edward Hayward, Housing, 1907, p.140

672 Alden, Percy and Charles F. G. Masterman, Democratic England, 1912, p.201ff

${ }^{673}$ Alden, Percy and Edward Hayward, Housing, 1907, p.142
} 
In his three quoted writings, The Unemployed. A National Question (1905), Housing (1906) and Democratic England (1912), Alden emphasised the national dimension, the national repercussions of and the nation-wide collective responsibility for social problems such as unemployment or housing. He did away with the traditional view of classical political economy that the natural cycles of industry and commerce should not be interfered with and that the unemployed were best left to fight for themselves. Alden argued that, on the contrary, it was in the interest of national efficiency and to Britain's advantage in the international market to use to its fullest capacity the workforce available, including the many whose labour went to waste or whose efficiency and health were eroded in frequent periods of unemployment. To solve the problem of unemployment Alden thus pleaded for state intervention and a large-scale national effort through labour colonies, municipal relief works and the state-directed creation of new industries.

The problem of slumdom, too, could in Alden's eyes be at least partly be traced back to a mistaken policy of laissez faire in the building trade. Private enterprise had failed to provide adequate housing for the worse-off. Alden believed it to be the state's responsibility to offer affordable and healthy accommodation suitable to their needs to those who could not fend for themselves on the competitive housing market. Alden anticipated a real benefit to the nation in the shape of healthy, contented and efficient workers and robust children growing into dutiful citizens of the British Empire. The emphasis on humanity and human dignity which played a major role in the thought of the two other theologians in the study, William Booth and Steward Headlam, took a back seat in the argumentation of Percy Alden. He did, however, still regard persons as individuals with a right to respect and consideration, as can be seen in his discussion on unemployment and the unemployable. In the following chapters on non-religious thinkers, this attitude will gradually give way to a view of the worker as citizen, as a part of the community and a factor in national progress. 


\section{Non-Christian Socialists}

\section{Chapter 6 - Clementina Black and Underpayment: The Root Evil of Modern Industrial Society}

\section{Biographical Data: Clementina Black}

Clementina Black, the first of the non-religious thinkers to be examined in this thesis, looked at the social question from a woman's perspective. Her interest lay with the working class women in the poor neighbourhoods of the East End. In her social work and her publications, Black took the side of the female labourer whose position was particularly vulnerable. In addition to the problems encountered also by male labourers on which Headlam, Booth and Alden had concentrated, Black placed her focus on the added grievances and difficulties particular to working women who were largely excluded from existing organs of trade organisation and were especially helpless in the face of the fierce competition for labour. In her writings and her political activities, Black showed that the problem of sweating, the practice of employing labourers for wages below subsistence level, was a problem particularly pertaining to women.

Born in Brighton on July 27, 1853, her involvement with social issues began when she moved to London in 1879. Black soon gained access to the progressive political circles of the metropolis. Her sister Constance joined the Fabian Society at some time in the 1880s and Clementina accompanied her to meetings, although she never appears to have become a member herself. The 1880 s also saw the beginnings of a friendship with Eleanor Marx ${ }^{674}$ which brought her into contact with the revolutionary thought of the Marxist Social Democratic Federation. But in the case of the SDF, too, as with the Fabian Society, there exists no evidence, that she joined the organisation.

In the $1880 \mathrm{~s}$, Black was still bound to the principles of voluntarism and self-help. In 1886, she joined the Women's Protective and Provident League (WPPL), being elected honorary secretary to

${ }^{674}$ Eleanor Marx (1855 - 1898), youngest daughter of Karl Marx, was a socialist author and political activist. Eleanor Marx acted as her father's secretary. After his death in 1883, she joined the SDF, but seceded from the organisation with Edward Aveling and William Morris to form the Socialist League. Marx killed herself in 1898. 
the society only months after becoming a member. The Women's Protective and Provident League's aim was to further any activity and initiative designed to build up and strengthen its members capacity for self-help. Thus, the WPPL offered a voluntary insurance scheme against sickness and accidents; it provided recreational and educational facilities for girls and women for whom the supply of such facilities was often meagre ${ }^{675}$. The League also published a monthly magazine, the Women's Industrial News, which informed its members, among other issues, about changes in industrial legislation and explained to them the complex terms of the Factory Acts.

Under Black's secretaryship, the WPPL began to develop a particular interest in labour organisation for women workers. At the time, trade unionism was largely a male domain; most existing trade unions did not accept female members. Under Black's guidance, the League began to provide assistance, both in terms of money as well as know-how, to women workers who showed an interest in combining. Black explained in a letter to the editor of The Times of July 23, 1888: „Under whatever system workpeople are employed, the want of a proper trade organisation inevitably tends to the existence of conditions of employment in every respect unjust and oppressive. ${ }^{~} 676$ The League thus supported the London match girl strike of 1888 , collecting $£ 400$ for the strike funds. In keeping with their increasing emphasis on labour combination, the Women's Protective and Provident League changed its name to Women's Trades Union Provident Society in the aftermath of the match girl strike, and to Women's Trade Union League in 1891.

But acquaintance with the labour leader and trade union activist John Burns, among other factors, led to a radicalisation of Black's politics and her renunciation of the paternalist attitude to social reform of the Women's Trades Union Provident Society. In 1889, in collaboration with Burns, Black formed the Women's Industrial Council (originally known as the Women's Trade Union Association). The WIC was an organisation which operated among and on behalf of the poorest of the poor in the East End of London. By contrast to the Women's Provident and Protective League which held fast to the principles of voluntarism and self-help, the Women's Industrial Council took to political lobbying on behalf of poor women and their families alongside hands-on work in the slums. "The Women's Industrial Council is a body which exists for the purpose of collecting and spreading systematic and trustworthy information, of doing educational work, and promoting the election and appointment of women to public bodies and public offices", the Council's Objectives explained. ${ }^{677}$ Black's experience with voluntary initiatives had taught her that individual action, whether in the form of labour co-operatives or consumer associations, or of individual employers swimming against the tide of free competition, could only ever be a drop in the ocean of social

\footnotetext{
675 As quoted in Glage, Liselotte, Clementina Black: a study in social history and literature, 1981, p.26f

${ }^{676}$ As quoted in Glage, Liselotte, Clementina Black: a study in social history and literature, 1981, p.31

677 As quoted in Glage, Liselotte, Clementina Black: a study in social history and literature, 1981, p.40
} 
injustice.

Her new belief in the need for concerted political action led her to throw herself into the organisation of the Sweated Industries Exhibition of 1906 on behalf of the Women's Industrial Council. The Sweated Industries Exhibition laid open for the public to see the abhorrent working and living conditions of labourers in the unskilled trades who were powerless to negotiate for a living wage, many of whom were women. The Exhibition stirred up much attention and instigated a public debate on protective laws and the introduction of a minimum wage. The case for a minimum wage and legislative intervention was championed most forcefully by the National Anti-Sweating League which was formed in 1908 in the wake of the Exhibition. Clementina Black was a founder member of the League and later became its vice president. Behind her commitment to lobbying on behalf of sweated labour lay a new-found conviction that trade unionism "could not do for the unskilled trades what it could do for other trades, and they must look to the law for protection."

The two studies by Clementina Black which serve as key texts of the present chapter both deal with the problem of sweating and its possible solutions. Sweated Industry and the Minimum Wage ${ }^{679}$, published in 1907 with the support of the National Anti-Sweating League, was a powerful work which explored the origins of underpayment, described its consequences and appealed to the public conscience and political reason to eradicate the evil by legislative means. The Makers of Our Clothes $^{680}$, published in 1909, discussed the findings of case studies and door-to-door enquiries on working conditions in the dressmaking trades. Its publication appears strategically planned at a time when Parliament dealt with several legislative proposals on industrial issues such as the Trade Boards Bill.

Clementina Black had been brought up an atheist, her parents were a-religious. Her sister Constance with whom she shared a circle of friends and companions during her years in London eventually married an Anglican vicar and turned religious. There is no evidence to suggest that Black shared her conversion or took an interest in religious issues later in life. She did, however, acknowledge the social value of religious bodies as a result of her work among the very poor. She shared Henrietta Barnett's sentiment that churches had a definite civilising influence in slum neighbourhoods. "If these bodies did no more - and of course they do vastly more - than provide for the presence in each poor district of a few educated persons ready to give their time and knowledge to the service of their neighbours", she reiterated, "the public importance of them would be very great." 681 In some

\footnotetext{
${ }_{678}$ As quoted in Glage, Liselotte, Clementina Black: a study in social history and literature, 1981, p.55

679 Black, Clementina, Sweated industry and the minimum wage, 1907

${ }^{680}$ Black, Clementina and Adele Meyer, Makers of our Clothes: a case for trade boards. Being the results of a year's investigation into the work of women in London in the tailoring, dressmaking, and underclothing trades, 1909

681 Black, Clementina and Adele Meyer, Makers of our Clothes: a case for trade boards. Being the results of a year's investigation into the work of women in London in the tailoring, dressmaking, and underclothing trades, 1909 , p.6
} 
areas, she found that whatever there was of mental capacity sociability or enlightened recreation emanated directly from the church or chapel and she feared that if these institutions were to disappear, the whole level of some neighbourhoods would drop.

Possibly as an escape from the bleak realities encountered during her political work, Clementina Black also pursued an active literary career. Her choice of subject matter shows a leaning towards historical plots, some highly romanticised and sentimental ${ }^{682}$. But at least one of her eleven novels and several of her smaller works deal with social issues and point to the injustices and realities of industrial society. In her novel The Agitator, Black offered a realistic picture of working class life and problems in nineteenth century England ${ }^{683}$. Her rhymed exposition of the Factory Acts could be found in many workshops. In easily understandable words, the piece offered the basic tenets of the law concerning such matters as sanitary conditions, hours of work, accidents and factory inspection and in memorable phrases explained their rights to workers who may not have been able to read themselves ${ }^{684}$.

Clementina Black was also one of the few women who bridged the usual gulf between social activists and suffragists by embracing both causes. She described herself as an "eager advocate for women's suffrage" ${ }^{\$ 655}$. Her interest was in women and their conditions of life - be it as workers or as citizens. In discussing labour legislation and the first Factory Acts, she criticised the fact that women had had no voice in the shaping of the laws while being the first to be affected by them. "It is obviously inconsistent with the whole theory of representative government", she stated, "that laws of any kind should be imposed upon persons who have no voice in framing those laws." ${ }^{686}$ Like in her social activism, in her support of the women's suffrage movement Black favoured nonrevolutionary, non-militant means to attain the desired end. She sided with the peaceful wing of the movement alongside women such as the novelist and women's rights activist Elisabeth Haldane and Millicent Garrett Fawcett, the president of the non-militant National Union of Women's Suffrage Societies.

Clementina Black died in Surrey on Dec. 19, 1922.

\footnotetext{
${ }^{682}$ Glage, Liselotte, Clementina Black: a study in social history and literature, 1981

${ }^{683}$ Black, Clementina, An Agitator. [A novel.], 1894

${ }^{684}$ Black, Clementina, The Rhyme of the Factory Acts, no date

${ }^{685}$ Black, Clementina, Some Current Objections to Factory Legislation for Women, 1902, p.202

${ }^{686}$ Black, Clementina, Some Current Objections to Factory Legislation for Women, 1902, p.202
} 


\section{The Problem of Underpayment}

While Percy Alden and William Booth, for example, focused on unemployment as the central problem to be tackled in the fight against mass poverty, Clementina Black identified and concentrated on underpayment. In her opinion, underpayment rather than unemployment constituted the evil at the very root of the social problem. "We should succeed in grappling with the really unemployed", Black felt sure, "if we were not embarrassed by the half-employed and the inadequately paid." ${ }^{687}$ Her experiences during the Sweated Industries Exhibition and her enquiries into the living conditions of both homeworkers and factory hands in the East End brought home to her the reality of a life spent toiling and slaving in return for wages too low even for the necessary food and lodgings.

Underpayment, or sweating as it was commonly called, could take various forms. Based on her research, Black embraced a very broad definition of the concept of sweating. Originally, the term had referred only to the practice of sub-contracting where a person or firm commissioned to do a certain amount of work hired temporary „hands“, paying them excessively low wages out of the original sum received from the remitter. The practice was wide-spread and there existed entire workshops which operated solely with temporary labourers. Such workshops (or individual contractors) could easily circumvent factory legislation: they could work their labourers for long hours and usually took over little responsibility for their health and safety. Black widened the definition of the term sweating to include "almost any method of work under which workers [were] extremely ill-paid or extremely over-worked" ${ }^{\prime 68}$. By analogy, the term sweater signified to her any employer who cut down wages below the level of decent subsistence, worked his operatives for excessive hours or compelled them to toil under unsanitary conditions.

1878 had seen the introduction of the Factory Acts and with it certain checks on hours of work, sanitation and outwork. The Factory Acts provided for regular factory inspection and regulated sick leave in the cases of accidents at work. Yet, Black explained to her readers, the Acts referred to women and children only, and it was easy to evade the provisions. Black told of workshops located at the back of buildings which operated until late at night with no light to be seen from the street by inspectors passing the premises ${ }^{689}$. Other work places turned a blind eye to or even encouraged the

${ }^{687}$ Black, Clementina, Legislative Proposals, 1908, p.191

${ }^{688}$ Black, Clementina, Sweated industry and the minimum wage, 1907, p.1

689 Black, Clementina and Adele Meyer, Makers of our Clothes: a case for trade boards. Being the results of a year's investigation into the work of women in London in the tailoring, dressmaking, and underclothing trades, 1909, on evasions of the Factory Acts, see esp. Chapter XII „The Law and the Worker“ p.174-93 
taking home of work after hours even though the practice was expressly forbidden by the Factory Acts. Most importantly, the Acts dealt with only a fraction of the trades in which exploitation was common. It did not, for instance, touch laundrettes or the jam-making industries, trades notorious for their long and irregular hours and unhealthy working conditions, nor did it regulate predominantly male trades such as traffic workers and the railways.

In short, Black believed that existing legislation, although beneficial to a certain extent, did not go nearly far enough to deal with the problem of underpayment and left too many loop holes for employers to sweat their workers. There was, in fact, hardly an industry where underpayment was not still the rule in a great many workshops and factories, be it in the form of long hours, low pay, bad machinery, irregular work, payment by piecework, or waste of the workers' time in a fragmentation of the process of production. Underpayment, Black argued, could take many forms, but its result was always the same: terrible poverty and the destruction of potential and ability.

Black gave accounts of destitution designed to shock her middle class readers into action. Sweating, she pointed out, occurred in all contexts of labour, whether home work or factory employment. To her, conditions appeared worst for homeworkers. One room often served them as work space, sleeping quarters and parlour. Black reported on a visit to a woman employed as a match-box maker: "I have seen a room containing only an old bedstead in the very last stage of dirt and dilapidation, a table and two deal boxes for chairs. The floor and the window-sill were rosy with magenta match-boxes, while everything else, including the boards of the floor, the wood-work of the room and the coverings of the bed, was of the dark grey of ingrained dust and dirt." ${ }^{\circ 90}$ The worker occupying the room worked for a wage of $2 \frac{1}{4} \mathrm{~d}$ for every twelve dozen match-boxes. Black also gave the example of a family of eleven living in two rooms in the East End. The father was unemployed, the mother and four of her children worked in match-box making for a combined wage of $10 \mathrm{~d}$ to $1 \mathrm{~s}$ a day. "The conditions of life secured in return for this continuous and monotonous toil are such as might well make death appear preferable"691, Black concluded. Home workers did not benefit from the regulation of hours imposed on factories and workshops by the Factory Acts: their already long day was made even longer by the time spent going back and forth from the employers premises in order to catch or deliver work.

Factory workers, too, however, although they might nominally be under the protection of the law, often worked for wages which left them with food, clothing and lodgings only of the very poorest quality. Wages for factory hands frequently ranged from but five to ten shillings a week. Looking at the pay sheets of an unspecified confectionary firm in London, Black observed that out of 190

\footnotetext{
690 Black, Clementina, Sweated industry and the minimum wage, 1907, p.4

${ }^{691}$ Black, Clementina, Sweated industry and the minimum wage, 1907, p.5
} 
workers, only two earned as much as $16 \mathrm{~s}$ a week. 142 of them had received less than $10 \mathrm{~s}$ for the week preceding Black's visit, and 15 had been given as little as $4 s^{692}$. "An omnibus fare, a halfpenny newspaper, a penny stamp are luxuries in which only the thriftless indulge" ${ }^{\circ 93}$, Black described the limitations of such meagre wages.

Black pointed out the absurdity of the term "to earn one's living" in their cases. No young man or, more often, woman could live the life of a civilised human being upon a wage of ten shillings or less in a large town ${ }^{694}$. How much worse was it for women who had to support children or a family from their minimal earnings. Black wanted to alert her readers to the "cruelly heavy burden resting on the shoulders of the woman who tries to be at the same time mother, housekeeper and breadwinner; and who in return for endless exertion seldom receives enough even to keep her properly fed, and never enough to satisfy her own very modest standard of comfort." 695

Black explained to her audience that sweating could take on many different forms. Besides the paying of low wages, there were other, more subtle and often overlooked forms of sweating one's labourers. Among the several covert and overt forms of underpayment, for example, the deduction of fines and fees was a common variety. Many workers were forced to pay for materials or tools needed for their work. Dressmakers in London, whether homeworkers or factory hands, often had to pay for cotton, needles, oil and machine hire out of their meagre earnings ${ }^{696}$. Frequently, charges were greatly in excess of the real cost of materials. Black reported on a large box factory where deductions were made for glue, for gas to heat the glue, for string to tie the boxes together and for work books - amounting to as much as 1 s $6 \mathrm{~d}$ a week. ${ }^{697}$

In some factories, employers charged their employees for power, lighting, cleaning or standing room. "I have known instances in which the rent of a factory has been partly - perhaps wholly defrayed by a charge upon the workers who had to pay so much a week for their place in it" ${ }^{\prime 698}$, Black wrote. In factories, deductions were common for spoiled work and alleged damage, lateness, speaking and laughing or unseemly conduct. "Worst of all", Black discovered, "there are factories (...) in which piece-workers, when they have succeeded in making up a total slightly better than usual, are liable to have the surplus deducted." ${ }^{\prime 699}$

Sweating could also be exerted through unpaid overtime, Black wrote. Working hours could have a

692 Black, Clementina, Sweated industry and the minimum wage, 1907, p.28

${ }^{693}$ Black, Clementina, Sweated industry and the minimum wage, 1907, p. 25

694 Black, Clementina, Sweated industry and the minimum wage, 1907, p.47

${ }^{695}$ Black, Clementina, Sweated industry and the minimum wage, 1907, p.3

696 Black, Clementina, Sweated industry and the minimum wage, 1907, p. 8f; see also Black, Clementina and Adele Meyer, Makers of our Clothes: a case for trade boards. Being the results of a year's investigation into the work of women in London in the tailoring, dressmaking, and underclothing trades, 1909, p.24

697 Black, Clementina, Sweated industry and the minimum wage, 1907, p.43

698 Black, Clementina, Sweated industry and the minimum wage, 1907, p.42

699 Black, Clementina, Sweated industry and the minimum wage, 1907, p.46 
negative effect on wages especially for seasonal trades or for those who received a time wage. Extensive slack periods which might last for several months as, for instance, in the coat making trades could reduce wages which looked stately on the pay sheets of May or June to skimpy earnings if spread over the whole year ${ }^{700}$. Few employers paid extra for overtime. Shop assistants, too, tended to work excessively long hours. In poorer districts, Black found shop personnel who never went out of doors during daylight. "What wonder", she asked, "that they grow anaemic, that they suffer continually from headaches and indigestion, and from all the long train of woes that lie in wait for the over-worked, under-fed and shut-in women." 701

Shop assistants often had to deal with the additional problem of having to live in which in Black's eyes constituted yet another form of sweating. By governing their lives to the last detail by an often ridiculously extensive set of rules, the employer took possession, not only of his employee's labour, but of his or her entire time. The Truck Acts of 1887 had gone some way to remedy the evil by ruling that employers could no longer determine how any part of the wages paid should be spent or time passed out of employment hours, but Black believed that the practice of living in should be ended altogether ${ }^{702}$. The necessarily narrow horizon of shop assistants which came from hardly ever getting off the premises contributed, she held, to the collapse of health and nerves so often encountered in these women and the abolition of the practice of living in would, she envisaged, contribute to a marked improvement in the health of the whole class. ${ }^{703}$

\section{Some Mistaken Opinions on the Issue of Underpayment}

In her book Sweated Industry and the Minimum Wage, Clementina Black set out to clear up some of the misconceptions about the problem of underpayment and the causes of poverty among sweated labourers.

\footnotetext{
700 Black, Clementina, Sweated industry and the minimum wage, 1907, p.29; see also Black, Clementina and Adele Meyer, Makers of our Clothes: a case for trade boards. Being the results of a year's investigation into the work of women in London in the tailoring, dressmaking, and underclothing trades, 1909, p.25

701 Black, Clementina, Sweated industry and the minimum wage, 1907, p.54

702 Fox, Stephen N.undClementina Black, The Truck Acts: what they do, and what they ought to do, 1894

703 Black, Clementina, Sweated industry and the minimum wage, 1907, p.55
} 


\section{a) The Link between Low Pay and Bad Workmanship}

In a direct attack on Helen Bosanquet and the Charity Organisation Society, Black refuted the notion that in modern industry, pay followed the quality of work and that low pay constituted the just reward for work of poor quality. It was true that sweated labour often produced goods of very bad workmanship, Black conceded. But the relation between pay and quality was the other way round: although it was unfortunately not true that good work always earned good pay, it was certainly true that bad pay sooner or later led to bad work. "Without a certain modicum of food, comfort, good clothing, leisure and ease of mind, no human being long remains capable of producing good work" ${ }^{\text {"704, }}$, she explained.

Black considered low wages and long hours to be equally harmful to the workers' health. A railway company or omnibus company who kept a man at work for sixteen hours out of twenty-four used up more of the man's vitality than the other eight hours could restore, she argued. Similar harm was done to a man's or woman's vitality and efficiency when their wages did not suffice to restore to the body the energy - in terms of food, warmth and shelter - spent in the employer's services. "On every transaction", every hour spent working, Black argued, the labourer "[paid] out a little more than [was] returned to him" ${ }^{\text {705 }}$. No capitalist or share-holder, she argued, would be content with receiving less than his original input, but would expect an increase in the capital expended. And yet, employers called it a fair wage when they paid less than the equivalent of energy and life expended by the worker, justifying themselves by citing the market price of labour ${ }^{706}$. „Fair wages“ of that kind in the long run led almost inevitably to what Black likened to "bankruptcy" "07: early death or incapacity. In the interim period, the constant over-exploitation of mind and body would result in the slow corruption of ability and skill and thus to bad work.

Nor was it only the body which suffered through poverty. Like the other social reformers examined so far, Black was concerned that the underfed brain, too, remained stunted. To be constantly hungry, Black recounted her experiences among the poor, was to be constantly apathetic. Lassitude, inertia, mental dullness, no personal initiative and no activity save in response to external stimuli, these, she argued, were the characteristics of an adult whose childhood and youth had been passed in overcrowded rooms, whose nutrition had been insufficient, whose clothing inadequate and to whom no wider horizons had ever been opened. ${ }^{708}$ Such a half-starved, apathetic and mentally restricted human creature could not maintain a high output of work, Black impressed upon her readers, the

\footnotetext{
704 Black, Clementina, Sweated industry and the minimum wage, 1907, p.154

705 Black, Clementina, Sweated industry and the minimum wage, 1907, p. 165

706 Black, Clementina, Sweated industry and the minimum wage, 1907, p.161

707 Black, Clementina, Sweated industry and the minimum wage, 1907, p. 165

708 Black, Clementina, Sweated industry and the minimum wage, 1907, p. 274
} 
quality of the produce growing poorer and poorer; Black considered it doubly outrageous that employers thereupon often declared the work to be worth no more than the meagre wages paid. ${ }^{709}$

\section{b) Meagre Wages Not Due to Character Failings}

Black turned forcefully against moral interpretations of poverty and underpayment. She was adamant that low pay did not constitute the just reward for a deficient character. Like Alden and to a more qualified extent Barnett and Booth, Black spoke out against the view that poverty resulted from idleness, viciousness, or a lack of economy and thrift. "In every class there are no doubt undeserving persons", Black conceded, "but my experience of women working in their own homes (...) leads me to believe that their share of merit is quite unusually high." " of home and factory workers whom she visited in the course of her enquiries to be industrious, wellconducted, well-mannered people, respectable in the truest sense of the word. Their hard lot, she took pains to emphasise, was not the punishment for their own wrong-doings: "They are such good human material and for the most part so wasted." $" 711$ The habits and manners which onlookers so often interpreted as faults of character too often followed overwork and underpayment. Black told of bright young working girls who entered employment in good spirits, loyal to their superiors and colleagues, ready to work and uncomplaining; in the course of a few years of being sweated they turned into tired-out, hopeless, aggressive and listless women of whom it was impossible to guess whether their age was thirty-five or fifty. Sweating, Black found, gradually eroded their capacity of work and quenched personal initiative and inventiveness. The practice thus tended to destroy the very forces which made for national competitiveness and economic development.

Black expressed particular outrage at the accusation often levelled against the working classes that their poverty was the result of idleness and laziness. She recounted a visit to a young girl who earned her living packing cocoa. Black described her as of "ghastly appearance (...) [S]he was absolutely colourless, and although there was no sign about her of any specific illness, seemed exhausted literally almost to death" ${ }^{\text {}} 12$ The girl received a halfpenny for every gross of readily packed and pasted cocoa boxes. For every shilling earned she thus had to pack and paste twenty four gross of packets. Black calculated that for a very low weekly wage of $7 \mathrm{~s}$ the girl had to fill,

\footnotetext{
709 Black, Clementina, Sweated industry and the minimum wage, 1907, p.17

710 Black, Clementina, Legislative Proposals, 1908, p.188

711 Black, Clemetina and Adele Meyer, Makers of our Clothes: a case for trade boards. Being the results of a year's investigation into the work of women in London in the tailoring, dressmaking, and underclothing trades, 1909, p.17

712 Black, Clementina, Sweated industry and the minimum wage, 1907, p.25
} 
fold and paste 188 gross, or 21.792 packets $^{713}$. Black dared her readers to call the girl - and her peers who worked at similar rates for equally long hours in dress-making, match-box making, the jam industries or chocolate-making - idle. 'On a retrospect of our twelve months' work, the essential virtues of the woman worker - her patience, her industry, her marked sense of fair play stand out very clearly" ${ }^{914}$, she wrote of the many destitute sweated women working in the dressmaking industries, and she went on to stress: "Emphatically, the large majority of the women whom we have visited are good citizens who deserve well of their country, and who mostly receive in return for prolonged and patient labour a very small share in the joys, the comfort, or the beauties of life."

Contrary to popular mythology, Black wrote, thrift, too, was widely practised among the working classes in the narrow bounds possible. The total value of shares in industrial cooperative societies came to the vast sum of $£ 27.739 .123$ in 1904 , all of which had been scrimped and saved from already insufficient incomes. Black also pointed to the various trade union provident societies, friendly societies and penny banks. She quoted Life and Labour of the People of London ${ }^{715}$ to the effect that out of thirty families asked by Charles Booth and his collaborators about their saving practices, only five spent nothing on club money or insurance. The real problem, Black argued, was not the lack of thrift, but the lack of money: where incomes were too low for daily necessities, nothing could be set aside for future contingencies. "Upon 10s a week or less", she proclaimed, "the saving of money becomes something very close to a slow form of suicide." ${ }^{, 716}$ In the inevitably inadequate efforts to make provisions for cases of emergency or old age, workers too often denied themselves the absolute essentials of healthy living.

Not only was a lack of thrift definitely not a factor contributing to the poverty of the working classes, Black insisted emphatically. On the contrary, she considered the practice of saving a danger in itself. Against all established opinion, Black went as far as to recommend that workers abstain from all forms of thrift save shares in cooperative societies and trade union contributions. The return upon the latter was immediate and certain. The laying by of money for later, on the other hand, might cost the worker dearly. "To abstain from buying new shoes in order to save the price for one's old age, and then to die of pneumonia, induced by want of sound shoes, is but a doubtful form of thrift, both for oneself and one's nation" 717 , she reasoned. The interests of both individual and nation were indeed better served if the workers spent as much of their wages as possible to the best

\footnotetext{
713 Black, Clementina, Sweated industry and the minimum wage, 1907, p.26

714 Black, Clementina and Adele Meyer, Makers of our Clothes: a case for trade boards. Being the results of a year's investigation into the work of women in London in the tailoring, dressmaking, and underclothing trades, 1909 , p.11

715 Booth, Charles, Life and labour of the people in London, 1892

716 Black, Clementina, Sweated industry and the minimum wage, 1907 p.202

717 Black, Clementina, Sweated industry and the minimum wage, 1907, p.204
} 
advantage. By rejecting the practice of thrift, Black in effect propagated the same remedy as did Percy Alden and, as we shall see, John Robertson. Like them, Black recommended that the worker abstain from saving and re-infiltrate his income into the industrial cycle. Her motivation, however, was the hope for more material comfort in the present rather than an expectation of a future industrial boom.

Black also refuted the COS's reasoning that efficiency, good workmanship and consequently prosperity might be enforced by withdrawing support and forcing the poor to help each other. Morally, the charity of the poor towards the even poorer, be it relative or neighbour, might be a beautiful thing, but economically it was assuredly one of the causes which increased and aggravated poverty. "The maintenance of those who cannot maintain themselves by those who can barely maintain themselves keeps both groups upon a dead level of destitution" ${ }^{\text {"718 }}$, she remarked.

c) Popular Misconceptions about Economic Reasons for Low Wages

Black also rebutted the view that underpayment constituted a prerequisite of economic success and a safeguard of industrial expansion. She rejected the argument, for example, that foreign competition forced wages down. For one, many of the trades most renown for the meagre wages paid were not open to foreign competition. Black listed the building trades, transport and the large class of shop assistants who were on the whole gravely underpaid and overworked ${ }^{719}$. Also, the problem of sweated labour was not exclusive to Great Britain. Reports on the cotton mills in the Southern States of the US, for instance, showed a situation akin to conditions in Britain before the introduction of factory legislation ${ }^{720}$.

Black pointed to the example of the Lancashire cotton trade to demonstrate that raised wages, far from forcing the English out of business to the advantage of foreign competitors, might prove extremely beneficial to an industry. The cotton trade, she elaborated, had been the first to be touched by factory legislation. From 1802 the law gradually shortened hours for women and children, the main operatives of the trade. Simultaneously, trade union organisation ensured a steady rise in pay, from $24 \mathrm{~s} 9 \mathrm{~d}$ per week for an adult male in 1881 to $27 \mathrm{~s} 3 \mathrm{~d}$ in $1902^{721}$. Yet, returns in 1901 showed the industry to be continually expanding. Even though cotton was not native to Britain and had to be imported at considerable cost, Britain held a share of over 60 percent of cotton exports

\footnotetext{
${ }_{18}$ Black, Clementina, Sweated industry and the minimum wage, 1907, p.156

719 Black, Clementina, Sweated industry and the minimum wage, 1907, p. 86ff.

720 Black, Clementina, Sweated industry and the minimum wage, 1907, p.152

721 Black, Clementina, Sweated industry and the minimum wage, 1907, p.216
} 
among the Western nations in 1902. ${ }^{722 ~ " E n g l a n d ' s ~ t r a d e ~ g o e s ~ o n ~ s t e a d i l y ~ e x p a n d i n g, ~ y e a r ~ b y ~ y e a r ", ~}$ Black assessed; "wages rise, both nominally, and to a greater degree, really; and in the course of last year, not only was all the available adult labour employed, but it was not possible to get enough of it, so there was actually an increase in half-time labour, which previously had steadily declined." 723 The example of the cotton trade, Black argued, went to show that other things being equal that nation became wealthiest which paid its workers best. In the wake of decreasing hours and rising wages, Black found phthisis, spiral deformities and drunkenness to be on the retreat in North Western mills. In less than three generations, she observed, the cotton workers of Lancashire had become intelligent, independent and useful citizens of their country. "The increase in skill, dependent very largely upon an improved standard of life, has rendered possible a vast improvement in methods of production with the usual consequence of greatly enlarged output"724, she concluded. Health, skill and intelligence were the true bulwarks of national competitiveness, not low wages ${ }^{725}$, she argued. "The hope for England's industrial future (...) lies not along the lines of poor and ill-paid work, but along the lines of highest efficiency"726, she believed. It is worth noting at this point that Black's argumentative strategy differed greatly from the line of argument of the Christian thinkers examined in the earlier chapters of this thesis: by contrast to the Christian thinkers discussed above, in Black's reasoning, the individual worker figured principally as a factor in the community's well-being. The alleviation of his or her personal misery aimed primarily not at restoring humanity, self-respect and dignity to the individual, but served the economic progress of the nation.

The last preconceived notion on the causes of underpayment which Black did away with was the idea that cheap labour conduced to cheap goods. Many of her readers, Black held, believed that sweated labour produced goods targeted at, and affordable for, working class consumers. But Black refuted the idea of so linear and easy a link. Sweating was to be found in almost any trade. The production processes of modern industry were so fragmented and complex that with almost any product, individual steps may well have been completed by underpaid and overworked labour. Matchboxes, paper bags, undergarments, embroideries, flour sacks which were found in every home in the country had in all probability been produced by, or at some stage in the production process passed through the hands of, sweated workers. Any citizen using public transport, whether the railways or the London motor buses, availed himself of the labour of sweated drivers, conductors

\footnotetext{
722 Black, Clementina, Sweated industry and the minimum wage, 1907, p.221

723 Black, Clementina, Sweated industry and the minimum wage, 1907, p.223

724 Black, Clementina, Sweated industry and the minimum wage, 1907, p.225

725 Black, Clementina, Sweated industry and the minimum wage, 1907, p.269

726 Black, Clementina, Some Current Objections to Factory Legislation for Women, 1902, p.223
} 
and signalling men $^{727}$.

Black reported on tailoresses and clothes-makers who were paid even less in relation to the work required for a sophisticated silk blouse with heavy embroidery and double stitching than for a simple linen shirt as worn by the working classes ${ }^{728}$. "The taint is everywhere", Black reported; "there is no dweller in this country, however well-intentioned, who can declare with certainty that he has no share in the oppression of the poorest and most helpless among his co-patriots."729 Their blood, she declared, was on everyone's hands ${ }^{730}$. The Sweated Industries Exhibition of 1906 had greatly helped to show that sweating was a problem which concerned every single member of society. The visitors saw with more or less clarity that "sweating reduced to its true meaning was not the oppression of the poor in the interest of the poor; but the effort of an uneconomic system to extract from the misery of the unorganised, ill-equipped worker the equivalent of organised, wellpaid and well-equipped industry" ${ }^{\text {"731 }}$. Sweating did not make goods cheap, Black formulated - it only made labour cheap.

\section{The Causes of Underpayment}

Black argued that instead of being caused by any of the factors discussed above, sweating was the consequence of an industrial system reigned by the principle of free competition. Wages in a state of unlimited competition were determined not by the intrinsic value of the work performed, she explained, but by the relative need of the worker to sell and the employer to buy labour. ${ }^{732}$ Where sellers of labour were many and potential buyers few, she specified, the work would be paid for at a low rate, however excellently done, while where sellers were few and would-be buyers many, the work would be valued highly, however ill performed. At present, in Great Britain, workers in search of a job greatly exceeded the number of employers in search of labour. "Consequently, the wages of the manual worker are low in proportion to the cost of livelihood, and the individual worker is absolutely powerless by himself to increase them"733, Black wrote.

\footnotetext{
727 Black, Clementina, Sweated industry and the minimum wage, 1907, p.75

728 Black, Clementina and Adele Meyer, Makers of our Clothes: a case for trade boards. Being the results of a year's investigation into the work of women in London in the tailoring, dressmaking, and underclothing trades, 1909, p.153

729 Black, Clementina, Sweated industry and the minimum wage, 1907, p.22

730 Black, Clementina, Legislative Proposals, 1908, p.196

731 Black, Clementina, Sweated industry and the minimum wage, 1907, p.XI

732 Black, Clementina, Sweated industry and the minimum wage, 1907, p.152

733 Black, Clementina, Sweated industry and the minimum wage, 1907, p.153
} 
Black told of her experiences with women in search of employment at the factory doors. The foreman inquiring of one what wage she took would dismiss her immediately almost regardless of the amount she asked for and go on to the next person in line offering sixpence less than the aforementioned wage. "At seven and sixpence, perhaps, she gets taken on", Black described the process of lowering wages; "and when, presently, the slack time comes again, the girls weeded out, to be first discharged, are those who have been receiving eight shillings ever since their engagement in the previous season." ${ }^{" 734}$ Seven shillings and sixpence a week now became the usual wage until, in the next season, new workers would be taken on for another sixpence or shilling less. The tendency of wages in the underpaid trades was definitely downwards. Black gave the example of one middlewoman, the contractor hiring temporary hands in the process of subcontracting, in the shirt-making trade who in 1909 paid 5s for work for which she used to pay 10s or 11s twenty years ago and who in addition now also charged the workers for the cotton used ${ }^{735}$.

But poverty was not only the consequence, but also one of the main causes of underpayment, Black explained. "Wherever that unrestricted competition prevails", she said, "the ultimate price of any industrial process comes to be the lowest rate at which any worker will consent to perform the process." ${ }^{\circ 36}$ Many workers were so badly off that they had no choice in the matter of wages. Hunger often forced them to accept any payment on offer. It was a fight for bread in which the sweater played off the dire misery of one against the deeper misery of another. "For in this morass there is no minimum", Black pointed out, "the excess of labour is so great and the demand for food so urgent that the tendency is constantly downward." ${ }^{, 737}$ Destitution forced workers to underbid each other against their own long-term interests to a point below the sustenance line.

The downward spiral of poverty and sweating was reinforced by the fact that lowered wages forced families to bring more and more of their members into employment. Black reported that children were pressed into industrial employment at an ever younger age. Homeworkers sent their sons and daughters to carry produce to the employer's premises or to fetch new materials in order not to lose valuable working time. In some trades like paper bag making or match box making which required little skill and force, children worked alongside their parents to increase the family income to the bare minimum necessary for subsistence. A recent enquiry at a school in Hackney had shown that a quarter of the girl students worked in matchbox making, steel covering, baby shoe making or basket weaving before and after school. ${ }^{738}$ Sons often held jobs as delivery boys for milk, groceries or

\footnotetext{
734 Black, Clementina, Sweated industry and the minimum wage, 1907, p.147

735 Black, Clementina and Adele Meyer, Makers of our Clothes: a case for trade boards. Being the results of a year's investigation into the work of women in London in the tailoring, dressmaking, and underclothing trades, 1909, p.80

736 Black, Clementina, Legislative Proposals, 1908, p.191

737 Black, Clementina, Sweated industry and the minimum wage, 1907, p.XIII

738 Black, Clementina, Sweated industry and the minimum wage, 1907, p.109
} 
newspapers or in street trading. While their contribution constituted an invaluable and essential help for individual families, it served to aggravate the problem of sweating. "They, too, become competitors with healthy industry", Black wrote of the children, "and by increasing the family output actually serve to still further lower the starvation wages." 739 Thus, by and by, mother and children working together came to receive no more than the mother used to be paid when working on her own.

Supporters of Manchester liberalism and laissez faire tended to justify their economic model by invoking the principle of individual liberty. They propagated, and with some justification as Black conceded, to leave the employer and the employed to make their own bargains and considered any intervention on the part of for instance the state to be an infringement on Mill's treatise $O n$ Liberty $^{740}$. They believed that economic contracts fell under Mill's principle that society had no concern with the conduct of individuals as long as that conduct did no harm to others. Black agreed with their reasoning under the proviso that both partners in the bargain were free to take their own decisions and make their own terms. But sweating harmed individual liberty in at least two respects. First, it existed only because it built on the powerlessness of the very poor and exploited the fact that the hungry had no choice in conditions of employment. At least one partner in the bargain could thus not be described as free to take his or her own decisions. Secondly, by agreeing to underpayment and overwork, the sweated not only harmed themselves, but their fellow-workers.

"Every woman who consents to work twelve hours a day tends to enforce a twelve hours day upon every other working woman"741, Black described the mechanism. The complicated methods of modern industry, she believed, formed a network of interrelations in which no industrial action could be really single and merely self-regarding. In the highly organised factory system of Britain, the individual could not for him- or herself obtain conditions which differed from those of his or her fellow workers. Conditions of work and rates of pay were determined for all workers by the weakest among their number, the man or woman whose needs were the most pressing and who would agree to work for the lowest rates and under the worst conditions. "[A]ll observation shows that the unskilled and unprotected worker not only may be, but in the long run inevitably is, driven to work very long hours for a rate of pay which just secures subsistence, or even, where there are many partly supported competitors, falls below the subsistence line" ${ }^{742}$, she stated. Under a regime of individual bargaining, many wage-earners were thus not only unfree to make their own terms in a contract, but were also unable to avoid injuring their fellow workers.

\footnotetext{
739 Black, Clementina, Sweated industry and the minimum wage, 1907, p.XIII

740 Mill, John Stuart, On Liberty, 1859

741 Black, Clementina, Some Current Objections to Factory Legislation for Women, 1902, p.193

742 Black, Clementina, Some Current Objections to Factory Legislation for Women, 1902, p.195
} 


\section{Alternative Models of Economic Organisation and Existing Checks Against Free Competition}

Black argued that free competition and laissez faire were not the only possible or necessary model of organisation in a successful national economy. Even in industrialised Britain, she pointed out, alternative models existed side by side with free competition and proved by their success the viability of their underlying principles of fair pay and fixed rates of wages. She countered Manchester liberalism by pointing out that some departments of the modern British economy already demonstrated that a state of unchecked competition was neither necessary for a trade's success, nor was it even desirable. There existed certain branches of the economy which were entirely free of the evil of underpayment.

Crafts of skill like baking and brewing, gold smiths or carpentry, for instance, trades which demanded years of training, appeared to be immune against sweating, Black specified. So were certain departments of specific trades, like the printing trade which employed skilled type-setters alongside sweated delivery personnel. Black also listed the professions, hospitals, museums, libraries, the army and navy, the civil service and the post office to illustrate her point that trades might be run without the kind of free competition which set in motion the cycle of underpayment. "Military and naval officers are not asked what is the lowest figure at which they will consent to serve their country", Black stated rather dryly; "nor do we find in advertisements for town clerks or borough surveyors that preference will be given to the candidate willing to accept a reduction of pay.", 743

Even the trades most notorious for sweating like the dress-making trades featured wide differences in payment from one workshop or factory to the next. Black told of two girls, living within walking distance of each other in the East End who both worked pressing trousers. While one could make up to $16 \mathrm{~s}$ a week in a firm of good reputation, the other was paid but $7 \mathrm{~s}$ for the same work ${ }^{744}$. In the public transport business, the London County Council demonstrated that sweating traffic workers was not a necessary condition for staying in business. On the contrary, by introducing a ten hours day, a minimum rate of wages and extra pay for overtime for those occasions when fog, fires or heavy traffic delayed a journey, the LCC had established itself firmly in the business. More still, by offering better and safer service than its competitors, the LCC-run transport business had actually

743 Black, Clementina, Sweated industry and the minimum wage, 1907, p.181

744 Black, Clementina and Adele Meyer, Makers of our Clothes: a case for trade boards. Being the results of a year's investigation into the work of women in London in the tailoring, dressmaking, and underclothing trades, 1909 , p.50 
steadily expanded and made profits for the past decade ${ }^{745}$. Black inferred from these examples that underpaying labour was not essential for staying in business even where competitors resorted to that means.

Cooperative societies, which ran on the basic principle of fair prices for fair work, were in Black's eyes another flourishing example of an alternative model of industrial and commercial organisation. They, too, had proven successful in the face of sweated competition. The movement had considerable momentum and should not be underestimated in size and influence, Black believed. She recounted that in 1904, the total value of goods sold by cooperative societies was $£ 90.681 .406$. Their membership ran to 2.103 .113 people. Black pointed out that apart from checking free competition and ensuring fair trade, cooperatives had the added benefit of making men and women feel part of a larger community and the inheritors of a tradition. "[I]n the ocean of commercial competition", Black wrote, "cooperation lies like a fertile land inhabited by workers who are putting into their own pockets the profits of their buying and selling, and very often also of their labour."746 Checks against free competition were thus already in place in certain sectors of the British economy. Black explained that moreover there also existed a number of attempts to interfere with and to keep at bay the worst excesses of laissez-faire in other trades. She once more pointed to the terms of the Factory Acts. They had shortened hours of work for women and children and contributed to shortening those of men, introduced regular breaks, provided against overcrowding in the workplace and introduced the instrument of factory inspection. Although the Acts were not universally observed, in many trades they bore visible effects. "Sanitary conditions are still sometimes far from satisfactory, although greatly bettered of late years", Black wrote. "There is perhaps no point upon which the influence of women inspectors has been more beneficial."

Black remained true to her roots when she argued that the most effective check on free competition in existence was trade unionism. The analysis of the interrelation between poverty and wages in modern industry had shown Black that the individual was absolutely powerless by him- or herself to raise his or her wage. "The individual worker", she wrote, "who has no sort of monopoly [read: skill, A. M.] is no more able to regulate the payment for his services than an apple or a sack is able to regulate its market price," 748 By combining and agreeing on a certain minimum among themselves workers could to some extent withstand underpayment and break up the downward spiral of sweating.

The method of combining had proven particularly successful among workers of a certain level of

\footnotetext{
745 Black, Clementina, Sweated industry and the minimum wage, 1907, p.101

746 Black, Clementina, Sweated industry and the minimum wage, 1907. p.180

747 Black, Clementina, Sweated industry and the minimum wage, 1907, p.33

748 Black, Clementina, Sweated industry and the minimum wage, 1907, p.169
} 
training who could not be replaced quickly and easily as the example of the Lancashire cotton mills illustrated. Once again, Black insisted that some degree of regulation could prove beneficial to both sides of the bargain, employers as well as employed. Not only had the union in the cotton mills of Lancashire negotiated higher wages and shorter hours for the workers, but the benefits of their activism could also be reaped by the mill owners whose profits had soared thanks to the greater strength, health and efficiency of their better-paid labourers.

It was true, Black admitted, that with strikes the unions employed a powerful weapon potentially disruptive of trade. But in strikes, as in a war, Black explained, responsibility for the conflict rested with both parties and seldom in equal degree. In Black's eyes, the apportionment of blame depended largely on the cause for which each party fought. While the employer in most instances fought for cheap labour and the unions primarily for access to the amenities of life which the employer already enjoyed, Black was in no doubt who was to be condemned in industrial conflict. "In nine cases out of ten", Black argued, "the union is really fighting the battle of the whole nation, while the employer is fighting against it." ${ }^{749}$ Poverty was a great enemy of trade and progress and by fighting poverty, the unions supported the cause of national efficiency and economic growth.

Yet, with all her faith in the beneficial features of trade unionism, her experience as honorary secretary of the Women's Protective and Provident League during the 1880s had taught Black that trade unions by themselves were unable to destroy sweating in many industries, especially those in which the fabrication of parts was let and sublet "until the origin of the whole [was] found in the dim, one-roomed tenement of the slum where the victim of the sweater [carried] on her tragic struggle with famine" ${ }^{975}$. Labour combinations had succeeded in regulating wages in the great industries whose operations could only be carried on on a great collective scale. But there, too, were exceptions. The trade union of railway workers had grown strong over the past couple of years; yet, it had not succeeded in securing for its members reasonable working hours or decent rates of pay ${ }^{751}$. Trade Unionism had never yet been permanently successful in shortening the hours and raising the pay of casual and temporary labour, of the unskilled, homeworkers and women labourers, although the Women's Trade Union League, as the Women's Provident and Protective League called itself since 1891 , had made some headway among the latter in recent years ${ }^{752}$. Workers needed to have a certain level of pay and a certain amount of independence at their disposal in order to be able to combine, make contributions to a joint fund and to face the risk of unemployment or dismissal which went with labour disputes, Black explained. "Thus, the very poorest are shut out from the

\footnotetext{
749 Black, Clementina, Sweated industry and the minimum wage, 1907, p.184

750 Black, Clementina, Sweated industry and the minimum wage, 1907, p.XXIV

751 Black, Clementina, Sweated industry and the minimum wage, 1907, p.33ff.

${ }^{752}$ Black, Clementina, Some Current Objections to Factory Legislation for Women, 1902, p.195
} 


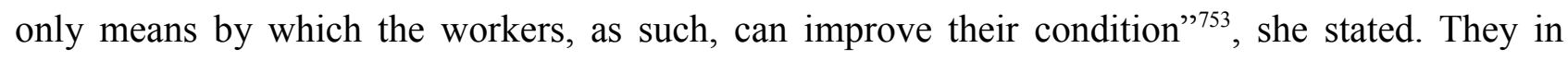
particular needed outside help and collective interference with the course of unlimited competition in order to be lifted onto a level where they were truly free to and capable of making their own bargains.

\section{The Costs to the Community and the Need for Collective Interference}

a) The Economic and Social Damages Done to the Community Through Underpayment

Black believed that the fight against sweating lay in the interests of the entire community. Sweating touched the life of every member of society. Black called it an organic disease of the body politic. The Sweated Industries Exhibition, she elaborated, had made it clear that underpayment "was an evil not simply affecting some obscure lives in the mean streets of our cities, but an evil that wasted the whole industrial physique - a running sore that affected the entire fabric of society, a morass exhaling a miasma that poisoned the healthy elements of industry"754. Black warned that no nation could hope to remain at the forefront of industrial development and economic growth who had at the bottom of its social pyramid this stagnant pool of wretchedness ${ }^{755}$. The sweated reacted upon the entire community. They constituted a menace to the health and prosperity of the entire nation and a drain upon the resources of society in the interest only of the people who exploited them.

Sweating harmed the community in various ways. First of all, Black explained that the practice of underpaying cost the tax payer very real money. At the community's expense sweating provided a reserve of incredibly cheap labour to individual employers. Many of the workers received wages well below the subsistence line; they could not live on their wages alone. It was the community which had to step in to provide support via the Poor Law where the worker's income did not suffice to feed, house and clothe him- or herself or their families. Sweating, Black impressed on her readers, meant the maintenance out of the rates of a vast mass of low class labour which enabled the sweater to compete successfully with high class labour ${ }^{756}$. Black stressed that in neighbourhoods

\footnotetext{
753 Black, Clementina, Legislative Proposals, 1908, p.194

754 Black, Clementina, Sweated industry and the minimum wage, 1907, p.X

755 Black, Clementina, Sweated industry and the minimum wage, 1907, p.XXVI

756 Black, Clementina, Sweated industry and the minimum wage, 1907, p.XII
} 
where wages tended to be low, poor rates were generally high. By supporting workers through the Poor Law, the community really only supported the sweater into whose pockets went the gain derived from selling the output of his workshop at a price much higher than what it had cost to produce it.

Secondly, besides costing the localities money through the increased burden on the Poor Law, Black held that sweating also stood in the way of development of industry and economic growth. The effect was threefold. For one, Black believed, the existence of this vast pool of cheap labour took away the need for employers to invest in modernisation. Sweaters "set the slum to compete with the workshop, the man or more often the woman and child to compete with the machine"757. Labour could be had so cheaply that it paid better to use it in abundance in uneconomic production processes than to invest in new machinery or improved methods of production ${ }^{758}$. The example of factory legislation among the cotton workers of Lancashire showed that if a minimum standard of sanitary conditions and rates of pay and a maximum number of hours were imposed, the employer was forced to extract the same value of produce from his hands in less time and for higher pay and was thus driven to look for alternative channels of saving such as providing the best machinery available $\mathrm{e}^{759}$. For the consumer, Black envisaged products of better quality and at cheaper selling prices from innovations in the methods of $\operatorname{production}^{760}$.

The second way in which sweating stood in the way of the development of industry and of economic growth was by lowering the quality and efficiency of the British workforce. Black impressed upon her readers that the worker by being paid below the subsistence level would eventually fall into disrepair and contribute less than his or her full share to the general wealth. ${ }^{761}$ "His existence is not an addition to, but a deduction from, the total general happiness", Black scolded, "the rather that underpayment is a burden not only to its victim but also to the onlooker." Thirdly, Black argued, sweating led directly to a lowered standard of consumption and thereby hindered economic expansion. She contended that the working classes formed the bedrock of commerce in Great Britain. Their condition reacted immediately upon society. Underpaid labour had no resources to spend and used less than their necessary share of clothes, furniture, or food. Well-paid labour, on the other hand, Black predicted, would immediately redirect their income into the general trade cycle adding comforts such as additional clothes, shoes or better tenements to their very modest standard of living. "The better paid worker, without premeditation or patriotic design,

\footnotetext{
757 Black, Clementina, Sweated industry and the minimum wage, 1907, p.X

758 Black, Clementina, Sweated industry and the minimum wage, 1907, p.XXIII

759 Black, Clementina, Sweated industry and the minimum wage, 1907, p.191; see also p.263

${ }^{760}$ Black, Clementina, Sweated industry and the minimum wage, 1907, p.191

761 Black, Clementina, Sweated industry and the minimum wage, 1907, p.18

${ }^{762}$ Black, Clementina, Sweated industry and the minimum wage, 1907, p.171
} 
tends, by the mere process of buying what he wants, to set his fellow countrymen working" "763, she believed. According to her reasoning, a rise in wages meant a rise in the volume of national trade and general prosperity and an almost automatic safeguard against foreign competition. The interests of the nation, she believed, were thus best served by the maintenance among working class families of the highest attainable standard of life ${ }^{764}$. Without using the terminology, her reasoning once again chimed in with Alden's and Robertson's arguments on a theory of underconsumption.

Thus sweating meant economic loss to the community, either in a very direct way through extra burdens on the Poor Law, or through standing in the way of industrial growth and economic development. But on top of these immediate losses Black warned her readers that sweating also brought in its wake an incalculable amount of follow-up expenses. Black pointed particularly to the harm done to children who were forced into industrial employment far too soon. Black emphasised the physical damage inflicted on growing children who spent several hours a day toiling at machines, lifting heavy weights or bending over minuscule match-boxes, baby shoes or toys. Remembering a visit to a factory in Lancashire in her capacity as secretary of the WPPL in the 1880s she wrote: "It was pitiful to see the twisted little figures of the children doing their best to accomplish more than they were physically fit for." ${ }^{\text {765 }}$ Children who had to work for their upkeep unusually often suffered from heart conditions, anaemia, spiral deformities, eye infections, or simply from sheer exhaustion. The Interdepartmental Committee on the Employment of School Children established in its report in 1901 an abnormally high death rate among pupils in industrial employment. Those who survived into adulthood, Black warned, would inevitably be physically damaged. They would from early injury, illness and overwork possibly become unfit to earn their own living well before their time and become a burden on the public purse, Black concluded.

But the damage done was not only physical. Educationally, children employed out of school hours tended to be several months behind their peers. Apart from doing lasting bodily harm, working out of school hours weakened their "powers of sustained attention and vigorous mental work in

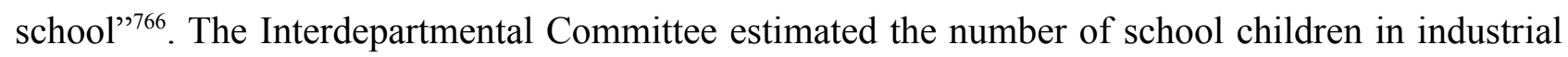
employment at about 200.000, the majority of whom would not get a satisfactory education. Black condemned the fact that they would have no chance to learn the skills necessary for an independent self-sustaining life, let alone be able to acquire the knowledge and mental powers required to contribute to industrial innovation or the cultural growth of the nation. "The deterioration of national education from this cause alone", Black stated, "must be by no means trifling."

\footnotetext{
${ }^{763}$ Black, Clementina, Sweated industry and the minimum wage, 1907, p.267

${ }^{764}$ Black, Clementina, Sweated industry and the minimum wage, 1907, p.204

765 Black, Clementina, Sweated industry and the minimum wage, 1907, p.111

766 Black, Clementina, Sweated industry and the minimum wage, 1907, p.126

${ }^{767}$ Black, Clementina, Sweated industry and the minimum wage, 1907, p.127
} 
School children in industrial employment, Black warned, did not usually acquire any sort of technical skill or industrial training through their labour. Nor did they generally graduate to more skilled and better paid employment in adult life. Her inquiries had shown Black that children in early employment often stuck to menial jobs requiring no special knowledge in adult life, often in sweated trades like matchbox making or the dressmaking industries, as they could not afford to take time off for training. Also Black pointed to the moral injury inflicted on children in, for instance, street vending which brought them into early contact with alcohol, vandalism, crime and prostitution and which often rendered them unfit for industrial employment in the future ${ }^{768}$.

Setting children to work at an early age was most injurious to the community, Black summed up her argument on the follow-up costs of sweating. "To look at this matter from its lowest plane", she impressed on her readers, "it is false economy to let the children of the nation begin industrial work at less than fourteen." ${ }^{~ 769}$ These children who constituted the citizens of the next generation were physically, mentally and morally damaged. They could not be expected to uphold and extend Britain's economic, military and cultural hegemony.

Black urged her readers to work towards social reform and to put in place provisions which would allow these children to grow into healthy, efficient and resourceful workers and citizens. The physical and mental degeneracy of the lowest strata of the working classes, she argued, was a result not of vice and ill-will, but of early malnutrition, illness and overwork and of the accompanying evils of hopelessness and apathy. The higher death rate, the inferior physique and the poorer vitality of the ill-paid marked tendencies not inborn but acquired, Black held, all of which would disappear with the diminution of poverty and of the ignorance which was an outcome as well as a cause of that poverty.

"Degeneracy exists", Black conceded, "but not a degenerate class; the class which we sometimes call degenerate is, as a class, merely starved." ${ }^{, 70}$ She believed it possible to diminish their misery within the very short span of three years and even predicted a total recovery within the lifetime of children already born if the problem of underpayment was attacked in a serious and effective way $^{771}$. Taken at an early age and housed, fed and clothed like the children of the better-off artisan, Black predicted, these children would "become healthy of body and alert of mind; a reader of books, a player of outdoor games, a skilled craftsman taking delight in his own good work, a citizen rending intelligent public service, a parent of healthy, hopeful children, enjoying and creating prosperity." ${ }^{\prime 772}$

\footnotetext{
768 Black, Clementina, Sweated industry and the minimum wage, 1907, p.128f

769 Black, Clementina, Legislative Proposals, 1908, p.205

770 Black, Clementina, Sweated industry and the minimum wage, 1907, p.274

771 Black, Clementina, Sweated industry and the minimum wage, 1907, p.274

772 Black, Clementina, Sweated industry and the minimum wage, 1907, p.275
} 


\section{b) The Need for Collective Interference}

Throughout her career as a labour activist, Black never gave up her belief in voluntarism. Individual action by employers, producers and workers all contributed to a successful struggle against sweating. But knowledge of the modern system of industrial production had taught Black that private initiatives could in themselves never be enough ${ }^{773}$. The complexities of modern commerce made it impossible for any individual or group, however well intentioned, to attain knowledge of the myriads of facts which would be needed to tackle problems such as underpayment or overwork at their roots. "The fact is", Black pointed to the interrelations of modern society, "that even the most simple of commercial acts is but one link in a network that spreads over the whole field of life and labour; and the fabric of that network is not woven once and forever, but is in a continual process of change." 774 The evil of sweating was too widespread and too remote in its operations to be touched by any small-scale voluntary action. Black pressed for institutional interference and legal reform to attack the problem of underpayment.

Black held that only the state as the powerful agent of the community could protect the sweated against the rapacity of their oppressors and safeguard individual liberty. She strongly believed that in doing so, the community preserved its own well-being and integrity. Legal action against sweating, Black argued, was not a question of pity, but one of necessity, a duty towards the common good. When individuals were too weak or too dependent to represent their own interests, she reasoned, the community had to step in on their behalf to put a halt to behaviour endangering society's set-up and values. State interference in the social and economic sphere, Black argued, was not a breech of, but a safeguard to the principle of individual liberty. The means at the disposal of society to stop dangerous conduct in social interaction and to protect the common good was the law, "the organised will (...) of the whole community"775.

Sweating in Black's eyes was an economic problem caused by unlimited competition. Any legal interference to be successful thus had to aim at checking the above evil ${ }^{776}$. "The law that free competition in labour leads to starvation wages is a law of the same kind as the law that a dose of prussic acid leads to death", Black believed. She drew the conclusion that in both cases, to avoid the result, one must avoid the cause: "persons who are not desirous of committing suicide must abstain from prussic acid; persons who desire to see underpayment vanish must resist free competition of

\footnotetext{
773 Black, Clementina, Sweated industry and the minimum wage, 1907, p.206

774 Black, Clementina, Sweated industry and the minimum wage, 1907, p.209

775 Black, Clementina, Legislative Proposals, 1908, p.195

776 Black, Clementina and Adele Meyer, Makers of our Clothes: a case for trade boards. Being the results of a year's investigation into the work of women in London in the tailoring, dressmaking, and underclothing trades, 1909 , p.9
} 
labour." $" 777$ In Black's eyes, the cure against sweating needed to be applied at the point of payment and the introduction of a legal minimum wage appeared the most direct and effective method of application $^{778}$. Other countries had successfully introduced measures to impose a minimum wage, she reported. She proposed to look to, for instance, New Zealand and Australia for inspiration and guidance in the matter.

\section{Possible Solutions: Wage Boards and Courts of Arbitration}

Black related that with regard to the fight against underpayment, the colonies were several steps ahead of Great Britain. Almost two decades before the Sweated Industries Exhibition stirred up publicity in London in 1906, a series of newspaper articles in the Otago Daily Times in January 1889 had brought home to the inhabitants of New Zealand the national significance of the industrial practice of sweating ${ }^{779}$. Black reported that to fight the problem of underpayment, the prominent Fabian and Rainbow Circle member William Pember Reeves ${ }^{780}$ who was at the time Minister of Labour in New Zealand crafted in 1894 a minimum wage law which was based on the idea of conciliation boards.

Conciliation boards grounded in the idea that effective state interference in the field of industrial conflict could not deal with individual arbitrations between man and man, but had to focus on arbitrations between interest groups. Pember Reeves' law thus provided for the establishment of local conciliation boards composed in equal proportion of employers and workers plus an impartial chairman. These stepped in at critical moments of industrial disputes, when strikes or lockouts threatened to erupt. The boards sought to substitute peaceful arbitration for those potentially very disruptive instruments. Thus, while cases were under hearing by the conciliation boards, no strikes and lock outs were permitted. The boards had full power to take evidence and to compel attendance. Pember Reeves' law prescribed that their decisions were legally binding to both sides unless appealed against within a month. For cases which could not be solved by the conciliation boards, the law established a supreme court of arbitration. The supreme court consisted of three members,

\footnotetext{
777 Black, Clementina, Sweated industry and the minimum wage, 1907, p.173

778 Black, Clementina, Sweated industry and the minimum wage, 1907, p.210

779 Black, Clementina, Sweated industry and the minimum wage, 1907, p.230ff.

780 William Pember Reeves (1857 - 1932), was a laywer, journalist and politician. Born in New Zealand, he came to London in 1896. He became friends with G. B. Shaw and the Webbs and joined the Fabian Society. He was also a member of the Rainbow Circle. From 1908 to 1919, he served as director of the London School of Economics.
} 
one independent chairman and one representative of employers' and workmen's associations each. It dealt with insurmountable conflicts in individual cases, enforced compliance with the board's decisions on either side and looked at the issue of minimum wages on a national level.

Although the Act took out of the workers' hands their principal weapon in labour conflicts, the strike, Black nonetheless thought that the law empowered workers in New Zealand to a degree unknown in Great Britain. The Act provided for peaceable and equitable settlement in cases where the parties failed to settle matters for themselves ${ }^{781}$. Also, under the Conciliation Boards Act, any group of seven workmen registered as an industrial union could appeal to their local board for better wages. Even the poorest and most helpless of labourers was thus made an active participant in his or her own emancipation. The employers could no longer play off workers against each other. "Would

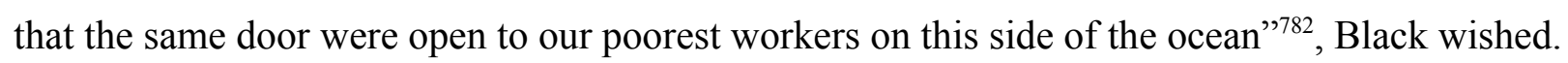

Australia, the other British colony which had already taken steps to deal with the problem of underpayment, had chosen a different model to settle her industrial conflicts. With the Factory and Shops Acts of 1896, the government had provided for the establishment of electory wage boards in the dress-making industries, the baking and butchering trades and the furniture business. These boards consisted of up to ten persons, five from each side in the conflict, who were appointed by their fellows. The boards had power to fix rates of wages and piece work rates, hours of work, rate of pay for overtime and the proportion of apprentices employed. By 1905, thirty-eight such boards existed.

But Black detected a number of problems of the Australian model of wage boards. First, the process of electing the representatives to the wage boards was, in her eyes, "extraordinarily cumbrous" Secondly, the wages and conditions fixed by these boards varied to a remarkable degree, the smallest advances being granted in the worst paid trades. Black detected a marked bias against women in some trades. Thus, the female chocolate coverer in Australia of over 21 had a minimum rate of only $17 \mathrm{~s}$ weekly, her companion below the age of 21 may be paid as little as $14 \mathrm{~s}$ a week, while adult male chocolate coverers earned a minimum of $30 \mathrm{~s}$. In the jam industries, the minimum for females of 18 years and above was $14 \mathrm{~s}$. On the whole, Black found that the decisions and enactments of most boards pointed "to a desire on part of the boards to prevent a further drop of wages rather than to effect a rise to what may be esteemed a 'living wage"'784.

Yet, despite their weaknesses, Black pointed out that without any further prohibitory effort, the wage boards appeared by the mere process of forbidding underpayment to have imposed a check

\footnotetext{
781 Black, Clementina, Sweated industry and the minimum wage, 1907, p.243

782 Black, Clementina, Sweated industry and the minimum wage, 1907, p.241

783 Black, Clementina, Sweated industry and the minimum wage, 1907, p.248

784 Black, Clementina, Sweated industry and the minimum wage, 1907, p.252
} 
upon the most unsatisfactory sorts of, for instance, home work. "Work given out only because it might be sweated naturally ceases to be given out when sweating is stopped"785, Black wrote. The tendency in all trades had through the provisions of the wage boards become to get the work done in factories where supervision was closer and where, with improved machinery, work could be turned out much more cheaply.

Black summarised her discussion of the Antipodean examples that both laws for the regulation of wages, the arbitration courts in New Zealand and the wage boards in Australia had demonstrably helped to raise wages and to diminish underpayment within their respective jurisdictions. Black favoured the Industrial Arbitration Act of New Zealand as a "very remarkable piece of constructive legislation", stressing in particular its "balance, its wide applicability and the simplicity and promptitude of its working" ${ }^{9786}$. Yet, despite their value as objects of study for the British economic legislator, neither Act in its colonial form was altogether suited to the needs of industrial Britain. Black pointed to a strong prejudice against compulsory arbitration among British trade unionists. She also criticised the slowness and cumbrousness of the wage board system which were features too much in accord with English "inertness" and "officialdom" for her liking. Black recommended a mingled version of the two for British application, wage boards to be appointed in the same manner as the New Zealand arbitration boards following the request of seven or more associated workers $^{787}$.

Black envisaged some evasions of the Act: she pointed out that a law which nobody desired to circumvent was superfluous. But to the employer who would be glad to pay better and felt himself hitherto prevented from doing so by the course of free competition, the establishment of a legal minimum wage would come as a great relief. So it would also to the conscience of the public much troubled at present by the problem of sweating. In all of Europe, Black wrote, the movement for the establishment of a minimum wage grew stronger. "As British women”, she proclaimed with her coauthor on The Makers of Our Clothes, Mrs Carl Meyer, "we hope that the credit of making the first step will belong - as the credit of the first Factory Acts belongs - to Great Britain." ${ }^{788}$ At the time of her writing the above in 1909, a Trade Boards Bill was discussed in Parliament in London.

As a social activist Clementina Black considered herself first and foremost an advocate of women's social and economic emancipation, and more particularly, of poor women's rights. But the problem of sweating which she treated in her two major non-fiction publications, was not restricted to female

785 Black, Clementina, Sweated industry and the minimum wage, 1907, p.255

786 Black, Clementina, Sweated industry and the minimum wage, 1907, p.258

787 Black, Clementina, Sweated industry and the minimum wage, 1907, p.259

788 Black, Clementina and Adele Meyer, Makers of our Clothes: a case for trade boards. Being the results of a year's investigation into the work of women in London in the tailoring, dressmaking, and underclothing trades, 1909, p.193 
labour and thus, by extension, her activism touched upon the lives of the poor as a class. She firmly believed that most poverty was economic in origin and thus beyond the influence of individuals. The only conceivable remedy to the evil of sweating as one cause of such poverty in her eyes was a tampering with the workings of the economic system, a check on free competition. Only the community as a whole could decide to change its economic set-up and modify the course of competition by its collective will, the law. Unlike Barnett, Booth or Headlam, Black's primary concern - or at least her argumentative strategy - was not for the individual soul and his or her emancipation, but for the well-being of society as a community. She did argue for an improvement of living conditions among the very poor and did point to the devastation and destitution among the sweated, but did not do so to demonstrate their degradation as much as to stress the cost to both individual and society in economic terms. She thus used the individual and his or her misery as the hub of an economic argument on national efficiency and economic growth.

The thinker to be discussed in the following chapter, the writer and politician Leo George Chiozza Money, leaned heavily on the idea of society as the prime beneficiary of social reform. With his proposals, he sought economic expansions as much as cultural and social growth: in a word, the progress of the entire nation. 


\section{Non-Christian Socialists}

\section{Chapter 7 - Leo George Chiozza Money and the Error of Distribution}

\section{Biographical Data: Leo George Chiozza Money}

The second thinker to be examined in the category of non-Christian reformers is Leo George Chiozza Money.

Sir Leo George Chiozza Money was born on June 13, 1870, in Genoa, Italy, as the son of an Italian naval engineer and an English mother. It is not entirely clear when he came to England, but in 1892, he married Gwendolin Maria Stevenson, daughter of a clerk at Hackney, in London. He made a living as a journalist on social, political and economic subjects. Already in his early work, he displayed a particular ability and liking for statistical analysis, a technique which was to feature prominently in his works on social issues. Between 1898 and 1902, he acted as managing editor of the Commercial Intelligence, a weekly newspaper dedicated to analysing the economic situation of the empire and to advocating free trade. In 1906, he was elected as Liberal MP for North Paddington, a function he exercised for various electoral districts until 1918. During the First World War, however, he grew increasingly discontented with the Liberal Party and became a member of the Labour Party in 1918.

In his first book British Trade and the Zollverein Issue ${ }^{789}$, published in 1902, Money presented himself as a Cobdenite free trade activist. He argued against imperial preference on the grounds that the empire neither presented a market big enough to absorb British export goods, nor did it offer sufficient supplies of re-imports into Britain in food and raw materials. Money followed up the text by a second book, Elements of the Fiscal Problem ${ }^{790}$, published in 1903, where he developed a simple argument in favour of free trade as preventing the growth of unsuitable industries and the development of monopolies. Money popularised his arguments in short instalments in the Daily

${ }^{789}$ Chiozza Money, Leo George, British Trade and the Zollverein Issue, 1902
790 Chiozza Money, Leo George, Elements of the Fiscal Problem, 1903 
News which, in 1903, he collected in a pamphlet entitled 100 Points for Free Trade ${ }^{791}$.

However, Money made his greatest impact on the political world of Great Britain with his book Riches and Poverty ${ }^{792}$, published in 1905, and later re-edited in a popular edition with striking charts and graphs on the inequalities of wealth and income in Britain. Surprisingly, within three years of his first book on free trade, Money had abandoned orthodox Cobdenism and embraced a more regulatory and interventionist view on industry and commerce. Unfortunately, in his surviving writings he gives no indication of what may have instigated this quite spectacular change of mind.

In direct opposition to his earlier arguments on the benefits of laissez-faire, by 1905, Money had come to believe that free trade no longer sufficed to check exploitation, the misallocation of labour and the misappropriation of capital and power. In Riches and Poverty, Money argued for a strong state as regulatory force in the allocation of labour and capital, and for a redistribution of means through taxation among other measures. He went beyond the agenda of New Liberals in his early advocacy in Riches and Poverty of nationalisation and the imposition of minimum wages in the sweated trades.

Money moved into political office as member of various select committees such as the Committee on Home Work in 1907/08, in which capacity he very likely came to know Clementina Black and her work. In 1915, he joined the War Trade Advisory Committee. He acted as parliamentary private secretary to David Lloyd George at the Ministry of Munitions in 1915, as parliamentary secretary to the Ministry of Pensions in 1917 where he drafted the new pensions scheme, as well as to the Ministry of Shipping from December 1916 to January 1919. Leo George Chiozza Money was knighted in 1915. In later life, he moved into the literary sphere, publishing anthologies and long poems such as The Immortal Purpose and Sonnets of Life $e^{793}$.

He died on September 25, 1944 in his home.

\section{Society as the Main Beneficiary of Reform}

In many respects, Leo George Chiozza Money sported the most radical programme of social reform among the thinkers under scrutiny in the present thesis. While the Christian thinkers discussed

${ }^{791}$ Chiozza Money, Leo George, 100 points for free trade, 1908

${ }^{792}$ Chiozza Money, Leo George, Riches and Poverty, 1905

793 Chiozza Money, Leo George, The Immortal Purpose, and other poems, 1924; also Chiozza Money, Leo George, Sonnets of Life, 1932 
above, foremost among them Headlam and Booth, focused on the individual as prime beneficiary of reform, Chiozza Money placed society at the centre of his social thought. Individual man, woman or child figured in his writings but as basic "units" 794 of the larger conglomerate of the social community. Money dreaded the degrading and corrupting effects of both excessive riches and dire poverty not on the individual, but on national life and feared that their negative corollaries endangered the social, economic and cultural health and growth of the British nation. He therefore called upon his fellow-citizens to put an end to the inequality resulting from the present system of private capitalism and to start putting national interests first.

It was the nation, Money stressed, which paid for the personal misery and misfortune of millions of citizens of all ages and abilities through the loss of their potential strength, intelligence and genius. He warned that every malnourished or crippled child, every unemployed workman constituted a dead loss to the community. "Year by year we bill off units of our population who might work good for their kind", Money pointed out. "Year by year we brutalise men who, given the opportunity, might enrich our literature or ennoble our arts." ${ }^{~} 795$ Society, he insisted, needed the service of all its members to the best of their respective abilities in order to expand and prosper.

Money demanded a radical re-organisation of the social and economic system of Great Britain in the interest of national life and growth. In a rich country like Britain, he believed, "poverty need be with us only as long as we care to tolerate it"796. It was within the power of the community to employ the wealth of society towards national ends if only Britain set her mind to it. Money's arguments in favour of a re-organisation of the economic system echo aspects of the contemporary debate on national efficiency as much as they display a deep concern for "social health", for a vigorous community working together to the best of its ability and with the best possible means available towards social, economic and not least, cultural, progress. In order to achieve this, Money called for an end to private capitalism, the nationalisation of all means of large-scale production and an empowered state with far-reaching jurisdictions as the representative and agent of the social body and the guardian of communal welfare.

Money's paramount esteem for society can be traced back to his belief that mankind, like any other species in the animal world, was subject to a process of evolution. Like all other animal creatures, man had to engage in a struggle against the destructive forces of nature, a struggle in which their chances rose immensely if men learned to pool their resources and combine in social communities. Society, to Money, was one form of organisation resulting from the process of mankind conjoining in groups cooperating for the dual aim of, first, survival and, secondly, progress.

\footnotetext{
794 Chiozza Money, Leo George, Riches and Poverty, 1905, for instance p.159ff

795 Chiozza Money, Leo George, Riches and Poverty, 1905, p. 175

796 Chiozza Money, Leo George, Riches and Poverty, 1905, p.155
} 


\section{The Conquest of Nature and Triumph of Civilisation}

With his emphasis on social evolution and mankind's struggle for existence, Money placed himself firmly in the intellectual context of New Liberalism. In his seminal study on the reformist ideology, the historian Michael Freeden argued that there was a strong strand of biologism and evolutionism to be found in New Liberal social thought. Freeden explained that New Liberals commonly resorted to images of nature and the animal world to explain the mechanisms and phenomena of human society. Darwin's theory of evolution and Spencer's idea of the "survival of the fittest" served many of them as analogies and models for explicating what they saw as the course of social progress and cultural evolution ${ }^{797}$.

Among the thinkers examined in the present thesis, Money alongside, as we shall see, John Mackinnon Robertson resorted to arguments and images drawn from biology and evolutionism most frequently. He traced poverty back to nature, arguing that it constituted a normal condition in the animal world. He had no sympathy for social romantics who used nature as a shining example of absolute harmony and universal comfort against which to remodel society. Nature was no Garden of Eden, he argued. Of the millions of tits hatched every year, Money gave as an illustration, the great majority died of hunger, exposure and early desertion or fell prey to wild animals within weeks of being born ${ }^{798}$. Mankind formed no exception to this natural process of selection, he maintained: until today, the majority of mankind, too, lived in a state of dire natural poverty which helped to regulate population growth and genetic quality.

Some of the higher races of man, however, Money pointed out, those who had learned to pool their skills and knowledge and to work together as a social entity, had succeeded in breaking the cycle of death and natural selection. Through their superior intellect and enduring courage, he believed, white men had studied the laws of nature and learned to apply them to their own advantage. Their combined intelligence had taught them to overcome some of the destructive forces of nature such as hunger and cold: they had learned to cultivate crops to counteract scarcities of food supply. They had tamed cattle and horses to help with their labour and provide milk and meat. They wore clothes and built houses against the cold and the rain and had through all of the above succeeded in greatly extending their life expectancy.

In the past one-hundred and fifty years the white races had made a particularly huge leap in their fight for dominance over nature, Money argued. Industrialisation had enabled them to produce

${ }^{797}$ Freeden, Michael, New Liberalism: an ideology of social reform, 1978, see esp. Chapter III „Biology, Evolution and Liberal Collectivism“

798 Chiozza Money, Leo George, Hope for the Worker, 1913, p.2 
goods in unknown quantities, amply sufficient to supply for an exploding population. New methods in agriculture and food processing and progress in the sciences, among them medicine, had made great inroads into mankind's original state of poverty. Money congratulated Western civilisation on its considerable achievements in fighting the destructive forces of nature. A death rate of one in three newborns in the slums of England was indeed too high to be tolerated, Money wrote. Yet, compared to the infantile mortality rate of nine out of ten among the birds in an "apparently healthy wood", he considered it "a triumphant measure of success."799

From that fact, Money drew his hope for the future of the British nation. English civilisation as it existed in 1905, he admitted, had its shortcomings - the slums, the ugliness of industrial plants, the smoke and pollution, the poverty and destitution. But he considered its achievements to be enormous compared to what nature herself provided. "Our right to entertain a legitimate hope for the future", he stated, "is born of contemplation of what has already been done." ${ }^{" 800}$ Man in modern society no longer had to accept destitution and want as the natural condition of his existence. Modern science and the knowledge gathered by generations past and present supplied him with the means to provide a comfortable life for himself and his fellow-men. "The poverty of old days", Money wrote, "was a poverty of ignorance; the poverty of today is a poverty in spite of knowledge." $" 801$

For civilisation to triumph in the continuous fight against the harsh conditions of nature, Money did not tire to stress, it was absolutely essential for all members of society to cooperate. Men had to conjoin their skills and knowledge, their inventive genius, their accumulated strength and enduring courage in order to solve still more of nature's mysteries and to carry society further towards progress and perfection. Money insisted that every single member of society needed to contribute his or her full share to the growth of industry and culture in order that man may conquer the destructive forces of nature and society may flourish.

In Money's eyes, it was therefore a dictate of reason in the interest of national evolution to see to it that all members of society possessed the means necessary to develop to their highest potential. Despite the high degree of physical morbidity and mental stultification to be found among the poor, he maintained, the human material which made up British society was basically good ${ }^{802}$. Nature, Money argued, intended to give everyone a fair and equal chance at survival at birth; at the outset of their life all members of society, whether born into a rich or a poor family, were thence equipped with equal promise and capability. It was only at a later point in life that the chances of the majority

\footnotetext{
799 Chiozza Money, Leo George, Hope for the Worker, 1913, p.4

${ }^{800}$ Chiozza Money, Leo George, Hope for the Worker, 1913, p.6

801 Chiozza Money, Leo George, Hope for the Worker, 1913, p.11

${ }^{802}$ Chiozza Money, Leo George, Riches and Poverty, 1905, p.159
} 
of the British nation were thwarted by malnutrition, exposure and unhealthy homes. Money reminded his readers that in this respect, nature worked into their hands: Britain saw the birth of 1.2 million new lives per annum, 1.2 million new and potentially successful units added to society while the old and faulty stock died out at a rate of seven hundred thousand a year. "Here is nature ever endeavouring to reform the race - ever offering an opportunity" ${ }^{\prime 803}$, he wrote. Money admonished his readers to seize the chance and propel the nation forward in its social and cultural development.

\section{The Error of Distribution}

a) The Maldistribution of Income

The main issue which in Money's eyes needed to be addressed in an attempt to give every member of society a fair chance and help them to develop to their highest potential was the unequal apportionment of wealth in early-Edwardian Britain. It was a state which in his book Riches and Poverty he called the „Error of Distribution“. ${ }^{804}$ Not only was material comfort a necessary precondition of social and cultural growth. Money argued that the only meaningful standard against which a nation's wealth and progress could be measured was the living standard of the majority of that nation's population ${ }^{805}$. For Britain, Money ascertained deplorable conditions for a large part of her thirty-eight million labouring citizens. An analysis of official Inland Revenue data on income tax and death duties revealed to Money a striking inequality of means among the various classes of society. It was this grave imbalance of material wealth which he subsumed under the catchy phrase of Error of Distribution.

Money believed that the annual national income of Great Britain would amply suffice to provide for every member of society if it were divided equally amongst the forty-three million citizens of the British Isles. Based on the Inland Revenue material, he estimated it at about $£ 1.710 .000 .000$. Nearly half of this sum, however, in total $£ 830.000 .000$, went to an estimated five million men, women and children, who together formed but one-ninth of the population ${ }^{806}$. The vast majority of thirty-eight

\footnotetext{
${ }^{803}$ Chiozza Money, Leo George, Riches and Poverty, 1905, p.160

${ }^{804}$ Chiozza Money, Leo George, Riches and Poverty, 1905, p. IX

${ }^{805}$ Chiozza Money, Leo George, Things that Matter. Papers upon subjects which are, or ought to be, under discussion, 1912, p.1

${ }^{806}$ Chiozza Money, Leo George, Riches and Poverty, 1905, p.41
} 
million British citizens divided between themselves but $£ 880.000 .000^{807}$. Even more strikingly, twothirds of that half, or $£ 585$ million, belonged to a mere 250.000 men and their immediate families. In other words, Money calculated, about one third of the yearly national income went to a tiny fraction of one-thirtieth of the entire population ${ }^{808}$. Money found his results confirmed when he examined the accumulated wealth of the United Kingdom. In an average year, he inferred from his study of death duty statistics, 27.500 people died worth $£ 257$ million, while the other 686.500 dead owned the equivalent of $£ 29$ million at the time of their deaths ${ }^{809}$. "About one-seventieth part of the population", he concluded from his study of official data, "owns far more than one-half of the accumulated wealth, public and private, of the United Kingdom." ${ }^{810}$

Money was alarmed by the fact that the divide between rich and poor was still growing. In 1911, he estimated in an article on the recent fall in real wages that the total sum collected through the national income tax between 1895 to 1910 had increased by 55 percent from $£ 678$ million to $£ 1.050$ million. Taking into account a slight increase in the number of income tax payers Money calculated that in the fifteen years under scrutiny, the average income of tax payers had increased by 35 percent, while in the same period, Board of Trade figures showed a rise in money wages among manual labourers of about 12 percent $^{811}$. This difference in income between rich and poor was further aggravated by a rise in retail prices which reduced real wages and affected low incomes more severely than large ones. The 12 percent rise in the money wages of labourers was counterposed by an increase in London retail prices for food by 17.9 percent and similar rises in the costs for clothing, shoes and other necessities ${ }^{812}$.

Money warned that through the maldistribution of income, which he had discovered through his study of death duty and income tax data, millions of hard-working men and women lacked the means to consume even the necessary minimum of goods. They lived in dire poverty. Like most of the writers already discussed in previous chapters, Money made short work of allegations that the poor themselves and their own bad habits had to be held responsible for much of the destitution. Alcohol and gambling, he alleged, were not the problem. If the one-third of the population whom social surveys had shown to be very poor „,could be gifted with all the virtues”, he wrote, "if drink were abolished and every penny spent upon scientific principles, (...) they would still be unable to

807 Chiozza Money, Leo George, Riches and Poverty, 1905, Introductory chart

${ }^{808}$ Chiozza Money, Leo George, Riches and Poverty, 1905, p.42

809 Chiozza Money, Leo George, Riches and Poverty, 1905, p.53

${ }^{810}$ Chiozza Money, Leo George, Riches and Poverty, 1905, p.72

${ }^{811}$ Chiozza Money, Leo George, Things that Matter. Papers upon subjects which are, or ought to be, under discussion, 1912, p.4-6

${ }^{812}$ Chiozza Money, Leo George, Things that Matter. Papers upon subjects which are, or ought to be, under discussion, 1912, p. 2 
command a healthy existence. ${ }^{, 813}$ The men and women at the bottom of the social scale were simply too poor to afford regular meals or a decent home, he wrote. A total annual income through manual work of $£ 655.000 .000$, the figure Money gave for the whole of Britain for the year $1904^{814}$, divided by fifteen million labourers plus their immediate families, did not provide them with means sufficient for a healthy life.

b) The Deleterious Economic and Social Consequences of the Error of Distribution

In Money's eyes, the inequality of means held the nation back in its cultural, economic and social development. The damage was done not only through the effects of mass poverty, but also through the moral corruption effected by great riches, he argued. Money believed that the damage wrecked through the maldistribution of income affected industrial growth as much as it did the nation's cultural progress and political set-up.

To give an example of how poverty harmed national well-being, Money - like Alden and Barnett before him - pointed to the state of housing. He related that a lack of means forced a large part of the population to live in houses which constituted "unfit habitations for a self-respecting people" 815 and were physically and morally damaging. Money estimated that almost 60 percent of the population of England and Wales lived under crowded or overcrowded conditions ${ }^{816}$. Of the tenements of the poor, fifteen years after the passing of the Housing of the Working Classes Act of 1890, he found a considerable proportion to be unsanitary or indecent, and most to be decidedly old, ugly and uncomfortable. Money listed the example of Salford Court, Central Manchester, where eleven houses shared "three wrotten places of convenience, only one of them usable" 817 . Liverpool, Leeds, Sheffield and London proffered similar neighbourhoods.

Like Barnett and Alden, Money stressed that under such conditions, disease and physical degeneracy flourished. He quoted death statistics of Hampstead and Southwark, males only, between 1897 and 1900, to illustrate how the poor were robbed "not of means alone but of life itself": the average expectation of life in Hampstead at birth ranged at around fifty-one years, while in the poor area of Southwark, it lay slightly above thirty-six years ${ }^{818}$. In the same vein as the other housing reformers under discussion here, Money added to the disastrous physical effects of

\footnotetext{
${ }_{813}$ Chiozza Money, Leo George, Riches and Poverty, 1905, p.160

814 Chiozza Money, Leo George, Riches and Poverty, 1905, p.26

815 Chiozza Money, Leo George, Riches and Poverty, 1905, p.194

${ }^{816}$ Chiozza Money, Leo George, Riches and Poverty, 1905, p.196ff

${ }^{817}$ Chiozza Money, Leo George, Riches and Poverty, 1905, p.198

${ }^{818}$ Chiozza Money, Leo George, Riches and Poverty, 1905, p.195
} 
overcrowding the aspects of ugliness and inconvenience and warned against the negative moral results of such an environment. "We have still to learn", he observed "that while the dwellings and surroundings of the people are unlovely we cannot hope for a gifted race." To the ill-distribution of monetary funds was added through slum neighbourhoods an ill-distribution of the means of a beautiful life. "The majority of our people are denied the vision of beauty", Money lamented, "and even those who receive a fair wage perish morally for lack of that vision." ${ }^{819}$ Through forcing the majority of the population to live in ugliness, squalor, dirt and disease, he warned, the nation let go to waste an enormous potential, both in terms of physical strength and industrial efficiency, as well as of creative energy and innovative capacity.

But not only poverty, Money maintained, cost the nation dearly. Like Henrietta Barnett, he pointed to the morally corrupting effects of great wealth on both individual and society. Their capital helped sustain the rich in a wasteful and injurious idleness, he criticised. Money compared the wealthy to drones in a bee hive ${ }^{820}$. They acquired their money not through any form of personal ability or merit, whether in the form of manual labour or inventive genius. Their unduly large share of the national income was allotted to them thanks to the faults in the economic system.

Money pointed, for instance, to the share-holder system and joint-stock companies which helped to cement the unfair distribution of income: using the example of a non-specified gas-work, he explained that all employees of the works, including managers and directors, shared barely one-fifth of the total profits in wages and salaries, while the non-working partners in the joint-stock enterprise divided among themselves the other four-fifth ${ }^{821}$. Money considered it a dangerous perversion that through the system of shares and sleeping partnerships, professional idleness paid much better than manual or mental labour.

Because the rich commanded half of the nation's annual income, their influence on a nation's social and cultural growth was much greater than their limited number merited, Money believed. By way of their expenditure, the wealthy dominated the economic life of society. Capital commanded labour - and true to Adam Smith's classic distinction between productive and unproductive employment, Money lamented that the rich commanded too much labour to be wasted in the production of luxuries, unnecessary service and export goods. Any one person could only consume a limited amount of useful commodities, he explained. Superfluous income either had to be saved and thus withdrawn from circulation or go to waste through the production of goods unnecessary for a comfortable life ${ }^{822}$.

${ }^{819}$ Chiozza Money, Leo George, Riches and Poverty, 1905, p.200f.

${ }^{820}$ Chiozza Money, Leo George, Riches and Poverty, 1905, p.128

${ }^{821}$ Chiozza Money, Leo George, Riches and Poverty, 1905, p.95ff.

822 Chiozza Money, Leo George, Things that Matter. Papers upon subjects which are, or ought to be, under discussion, 1912 , p. 262 
In Money's eyes, the labour expended upon any special Ascot frock, on any unnecessary piece of silverware of furniture showpiece was lost to the nation at large. Worse still, it degraded through its uselessness the people employed in its production ${ }^{823}$. "A working man may resist the temptation to ape the vices which are bred of idleness", he claimed, "but the highest standard of morality cannot save him from degrading his manhood in the service of waste." 824 There was no doubt in Money's mind that given the choice, any honest working man would prefer to erect a solid and comfortable home for a fellow-labourer and his family instead of building a second or third country house or palace, never to be inhabited properly, in the demoralising service of the wealthy ${ }^{825}$. The corruption and self-degradation which Money ascribed to the rich thence formed "not a stagnant pool which we may avoid, but a stream which flows through and pollutes the lives of the majority of our people" $\$ 26$.

Money also detected a political dimension to the maldistribution of means. As a liberal, Money felt particularly outraged by the fact that on top of condemning the vast majority of the population to poverty and destitution, the present social and economic system also took away their basic political rights. Untampered capitalism subjected the working man to a "servitude the shackles of which are as real as those of bondslaves" 827 . To talk of Britain as a democratically governed country was "utter cant" ${ }^{\prime 228}$, Money believed. The lives and labour of the great majority were not regulated at Westminster, but determined by the wealthy classes who acted as employers and chief consumers and thus had the power to decide how a man should spend his life; all too often, it was wasted in the service of luxury and extravagance.

"Let it be clearly understood, as things are, there is only one real form of government that matters, and that is the rule of the employed by the employers, ${ }^{, 829}$ Money wrote. Parliament was very far off indeed from the lives of ordinary men and women. Under the present maldistribution of means, the law had but negative power to decide what a man should not do. It could not grant him liberty and opportunity to take life in his own hands ${ }^{830}$. Money envisaged a state of society where all were liberated from the economic serfdom of capitalism and free to contribute to the life of the community as they saw fit: "The goal before us is to secure national organisation in the shape of truly democratic institutions in which the free election of an educated people shall find its expression and in which every man shall feel that he has a real voice in the government of the

${ }^{823}$ Chiozza Money, Leo George, Riches and Poverty, 1905, p.137

${ }^{824}$ Chiozza Money, Leo George, Riches and Poverty, 1905, p.128

${ }^{825}$ Chiozza Money, Leo George, Riches and Poverty, 1905, p.136

${ }^{826}$ Chiozza Money, Leo George, Riches and Poverty, 1905, p.128

${ }^{827}$ Chiozza Money, Leo George, Hope for the Worker, 1913, p.39

${ }^{828}$ Chiozza Money, Leo George, Riches and Poverty, 1905, p.255

${ }^{829}$ Chiozza Money, Leo George, Riches and Poverty, 1905, p.256

${ }^{830}$ Chiozza Money, Leo George, Riches and Poverty, 1905, p.257 
nation because he has equal power with his fellows." ${ }^{831}$

Money's vision of a truly democratic nation encompassed his demand that the false and evil division of the nation into two groups - one toiling, the other entirely relieved from manual work be abolished. ${ }^{832}$ He shared Stewart Headlam's vision of a society, as detailed in Chapter Two of this thesis, in which everybody would have to do his or her share of labour and contribute to the welfare of the community. Money expected great advantages for society from a universal mobilisation for work. Modern machinery gave enormous results for little labour. Adults would have to work for no more than five hours a day, he estimated, leaving ample time for private pursuits - to the enhancement of culture and beauty and the gain of civilisation, so he hoped. "No man can develop a proper balance of mind and body", he wrote, "who is condemned to mining or machine-minding or any common industrial process for the greater part of his waking hours." ${ }^{833}$ Adults would use their new freedom for tasks agreeable as well as useful to them, Money envisaged, such as sewing and embroidering, carving and painting, writing and studying. Money also hoped for leisure used for the invention of new machinery and production methods in order to further optimise the economic processes of Great Britain.

But the maldistribution of means did not only waste industrial and cultural potential and corrupt the nation morally. Money traced back many of the economic troubles of Great Britain directly to the Error of Distribution. He believed that the maldistribution of means played havoc with trade and commerce. In a vicious circle, he explained, the unequal apportionment of income re-acted on the nation's industry and caused still more misery and poverty. He blamed it directly for the sorry state of employment in Great Britain by preventing the major part of the population to consume their fair share of the nation's produce and thereby hampering the expansion of the nation's economy.

Like Black and Alden and, as we shall see in the next chapter, Robertson, Money recognised the illeffects of underconsumption on British trade. Many industries, he explained, suffered from the lack of spending power among the working classes and their inability to buy, for instance, new clothes or shoes. "The fact is, of course," he pointed out, "that while 6.000 .000 poor householders lack the means to buy boots, some tens of thousands of unduly rich households are squandering those means and in effect commanding men to leave the boot trade." 834 While the rich consumed the means of living of the poor, Money believed, useful trades languished. Money cited the case of the national cotton industries: out of a total annual produce worth $£ 90$ million, only goods worth $£ 18$ million, or an equivalent of 10 s per head per annum, were sold in Great Britain. Money's calculations of actual

${ }^{831}$ Chiozza Money, Leo George, Hope for the Worker, 1913, p.50
${ }^{832}$ Chiozza Money, Leo George, Riches and Poverty, 1905, p.43ff
${ }^{833}$ Chiozza Money, Leo George, Hope for the Worker, 1913, p.38
${ }^{834}$ Chiozza Money, Leo George, Riches and Poverty, 1905, p.135 
need, based on a very moderate standard of comfort, however, indicated that a family of five could easily consume cotton goods worth about $£ 4$ per year if only they had the funds ${ }^{835}$. The cotton industry thus suffered considerable annual loss through the maldistribution of means.

Money believed that it was the prevalent economic system of private capitalism and unlimited competition which had caused and perpetuated the unfair allocation of means. The data examined in the first half of Riches and Poverty and the enduring urgency of the social question convinced Money that the system of private enterprise which condemned the majority of the British people to a life in poverty seriously harmed the nation and held her back in her evolutionary processes.

Part of the problem in Money's eyes was that industry run privately and for personal gain offered too much opportunity for abuse and mismanagement. It accorded more than ample opportunity for work to be ineffectual and wasted. Antiquated machinery or out-dated methods of production, for instance, produced commodities of inferior quality ${ }^{836}$. Other goods were intentionally manufactured cheaply and of bad workmanship in order to sell them to the poor. At the same time, private capitalism aligned itself with wealth and focused on the production not of necessaries, but of luxuries which promised immense profits to the manufacturer.

Also, the competitive system of industrial production resulted in a myriad of manufacturing plants of varying sizes which all required their own sites, machinery and clerical staff - all wasted in Money's eyes. The distribution and marketing of commodities via middlemen, brokers and retail shops resulted in a multitude of unnecessary transactions and superfluous labour. "Underpaid or not paid at all, wrongfully employed or unemployed, overworked or underworked, these conditions are the inevitable accompaniments of a state of society in which individuals make bargains with individuals with a view not to service, but to profit ${ }^{\prime 837}$, Money wrote.

Money believed that modern science had equipped man with the knowledge and resources to produce enough food and consumer goods to offer all citizens of the British nation a comfortable standard of living. The free market policy of the nineteenth century had managed to supply with the means of a comfortable life only an unacceptably small number of citizens. "The fruit of Science is cultivated in arduous and often unnecessary toil by the many, and eaten by the few", Money lamented $^{838}$. Commerce thwarted and denied the work of science and used its gifts unintelligently and sparingly. With reference to his phrase Error of Distribution, Money called this state the grave

\footnotetext{
${ }_{835}$ Chiozza Money, Leo George, Riches and Poverty, 1905, p.135

${ }^{836}$ Chiozza Money, Leo George, Things that Matter. Papers upon subjects which are, or ought to be, under discussion, 1912, p.291f.

837 Chiozza Money, Leo George, Riches and Poverty, 1905, p.256

${ }^{838}$ Chiozza Money, Leo George, Things that Matter. Papers upon subjects which are, or ought to be, under discussion, 1912, p.272
} 
"Error of Production" 839 . In his writings, he therefore set out to offer a plan to re-organise the economy in such a way as to abolish waste, optimise output and even out the standard of living of the British population.

\section{The Limits of Existent Checks on Unrestricted Competition and the Need for a Strong State}

To Money, the present system of unlimited competition and laissez-faire had proven that in the absence of any form of control and coercion, the individual could not be trusted to act in the best interests of the community and work towards its progress and evolution. He lamented that free competition encouraged men to seek their own highest good regardless of their fellow-citizens' fate and the common good of the nation.

In the interests of social growth and cultural development and the triumph of civilisation over the destructive forces of nature, Money thus believed that the solution to the social problems of turn-ofthe-century Britain lay in a very high degree of state control over many central aspects of her citizens' lives. He wanted to install the central government as impartial, representative and commanding agency of a civilising and evolving community whose only interest lay in the progress of the nation and the furthering of the common good. The points on his social agenda thence all aimed at strengthening the state as prime director of the economy as well as of social life.

Money saw no alternative to a strong state. He considered many of the checks on unlimited competition and on the ill-effects of private capitalism which his fellow-reformers discussed in this study advocated to be ineffectual. The strength of trade unionism, for instance, continuously declined in Great Britain in the face of the growing power of employers' federations, he stated. While in Germany, between 1899 and 1909, trade union membership more than doubled from 864.000 to 2.097 .000 , in Britain the figure rose only by a modest 28 percent. In 1909 alone, German trade unions gained 540.000 members, or 25.000 more than British trade unions gained in ten years. ${ }^{840}$ It took Money no wonder that in two simultaneous labour disputes in the shipbuilding trades in Britain and Germany at the end of 1910, the German strikers managed to obtain far better

${ }^{839}$ Chiozza Money, Leo George, Things that Matter. Papers upon subjects which are, or ought to be, under discussion, 1912 , p.273

${ }^{840}$ Chiozza Money, Leo George, Things that Matter. Papers upon subjects which are, or ought to be, under discussion, 1912, p.7 
conditions and a considerable increase in wages, while British unionists eventually had to agree to end their strike after a lock-out on the sole condition that strikers not be punished by their employers $^{841}$.

The conciliation boards advocated by Clementina Black, too, failed in Money's opinion to assist the workers in their fight for a fair share of the nation's produce. Money quoted an estimate of the Board of Trade that in 1912, about two million workers were ruled by conciliation boards. Of the 7508 cases settled by the boards in the ten years between 1900 and 1909 only 104, or less than two per cent, were preceded by a stoppage of work. Money disagreed with the Board of Trade which noted the figure as a sign of success. In Money's eyes, the conciliation boards had not only failed to raise the standard of life among working men. They had even failed to prevent a further decline through the recent fall in real wages. Money cited a settlement negotiated by David Lloyd George as President of the Board of Trade in 1907 between railway companies and their employees to show how conciliation might turn to the disadvantage of workers: the negotiated increase in the rates of already very unsatisfactory wages for the five years following the settlement were exceedingly low, he showed. Workers in receipt of a wage of $23 \mathrm{~s}$ per week or less were awarded an extra shilling, employees with wages of $24 \mathrm{~s}$ or above were to receive an additional sixpence per week under the treaty. Money pointed out that many of the renegotiated wages still fell well below Seebohm Rowntree's primary poverty line of $21 \mathrm{~s} 8 \mathrm{~d}$ a week. ${ }^{842}$

Even social legislation as enacted under the Liberal government since their landslide of 1906 did not go far enough, as Money stated in his book Things That Matter which he published in 1912. In his eyes, the only solution to the social problem was that the state take total control of those aspects of social life which potentially harmed the community. Using the example of the Workman's Compensation Act, introduced in 1906, he showed how leaving the particulars of implementation to private insurance companies undid the potential benefits of the act and cost both employers and employees dearly. "[W]e have set up a great and far-reaching liability, and then have washed our hands of the matter", he criticised. The result was a "scramble of the most unhappy character" 843 where the machinery of private capitalism and unlimited competition between insurance companies inflated the premiums to be paid by the masters and deprived many a workman of his rightful compensation. Money contrasted the "clumsy, unjust, ineffective and costly" private insurance

\footnotetext{
${ }^{841}$ Chiozza Money, Leo George, Things that Matter. Papers upon subjects which are, or ought to be, under discussion, 1912, p. 8

${ }^{842}$ Chiozza Money, Leo George, Things that Matter. Papers upon subjects which are, or ought to be, under discussion, 1912, p.17ff

${ }^{843}$ Chiozza Money, Leo George, Things that Matter. Papers upon subjects which are, or ought to be, under discussion, 1912, p.116
} 
scheme in Britain with a "simple, just, effective and cheap" state-run system in Germany ${ }^{844}$. He called for the British government to take over from private companies. From a system of state insurance against injury through accident Money expected a disinterested administration of the Act, premiums which covered only actual claims and a swift and just distribution of compensation to the workman. Ultimately, Money hoped that a state-run system would help to prevent accidents as employers who mutually insured each other would themselves insist on common rules of safety in the workplace in order to reduce their costs ${ }^{845}$.

\section{The State as Motor of Social Regeneration: Nationalisation and a State-Run Programme of Redistribution}

Only the state, Money never tired to maintain, could be relied upon to act in the best interests of the community. He therefore planned to entrust it with any function and responsibility in the fields of social, political and economic (re-)organisation as well as the running of the nation's everyday life which in his eyes required an impartial eye or an even-handed executor. In Money's understanding these criteria applied also to the field of industrial production.

a) The Nationalisation of All Means of Large-Scale Production

Far ahead of the New Liberal agenda, Money urged for the nationalisation of all means of largescale production, notably of machinery, industrial plants and, a curious addition, the patents for modern production processes. Money called for an end to a system in which individuals without proper understanding and without a sense of communal responsibility could monopolise the great ideas of others and use the nation's inventive genius for private gain ${ }^{846}$. "If we are to abolish poverty for the masses of the people (...)", he wrote, "we must extend collective ownership to those impersonal forms of productive wealth in which the ideas of the inventors are embodied." 847

\footnotetext{
${ }^{844}$ Chiozza Money, Leo George, Things that Matter. Papers upon subjects which are, or ought to be, under discussion, 1912, p. 116

${ }^{845}$ Chiozza Money, Leo George, Things that Matter. Papers upon subjects which are, or ought to be, under discussion, 1912, p.122

846 Chiozza Money, Leo George, Hope for the Worker, 1913, p.28

${ }^{847}$ Chiozza Money, Leo George, Riches and Poverty, 1905, p.28f.
} 
Private ownership of industrial plants and private control of production processes, Money contended, was inconsistent with common welfare. It wasted resources, shunned responsibility towards labourers and consumers alike, and put private interests before communal welfare. On account of this Money aimed at the disowning of private capitalists and at a centralised organisation of industry. He thereby hoped to gradually eliminate the waste in labour and produce which prevailed under laissez-faire capitalism. Nationalisation, he believed, would guarantee the best service and produce at low prices for customers, a proper reward for labour, short hours, ample time for leisure activities as well as a steady income for the public treasury. It would also guarantee that labour be put to its best use in productive employment and that unproductive work - as, for instance, in the provision of luxuries - be gradually eliminated.

Money believed that organisation was the inevitable next step in an ongoing industrial revolution ${ }^{848}$. The alternative to nationalisation, he feared, was the rule of the "combine" or "trust". Already, he detected a tendency towards cartelisation in various economic fields, a trend which could "not be safely tolerated". Combination, he argued, threatened the public welfare in several respects, for instance by monopolising profits, by making it impossible for new capital to enter the field, by killing off trade unionism and increasing unemployment. In Money's eyes, cartelisation signified the wielding of the chief power in the state by monopolists who would use their authority for private ends ${ }^{849}$.

Nationalisation alone, he pressed, was consistent with true economy of labour. Money wished to see all monopoly in the hands of the community for communal benefit, not held by private capitalists for personal ends. Cases of municipal control of gas works, water supply and electricity had shown that the communal management of industry was feasible and profitable. So had the postal services and local sewage disposal systems. While democracy stopped short of the control of industry Money considered it "mocked". "A people cannot in effect govern itself", he held, "unless it has power of command over its own labour, and power to decide by democratic forms how and in what manner and to what ends the work of the nation shall be done. ${ }^{850}$ Money postulated an end to the economic and political serfdom of the working majority.

Nationalisation in Money's eyes also formed a necessary step towards owning up to society's responsibility towards the unemployed. In Insurance versus Poverty, published in 1912 as a popular manual to Lloyd George's national insurance programme, Money explained how all work, or nearly all work, was inherently irregular and would in some measure always remain so ${ }^{851}$. Like Alden,

${ }^{848}$ Chiozza Money, Leo George, Riches and Poverty, 1905, p.241

849 Chiozza Money, Leo George, Riches and Poverty, 1905, p.255

${ }^{850}$ Chiozza Money, Leo George, Hope for the Worker, 1913, p.46

${ }^{851}$ Chiozza Money, Leo George, Insurance versus Poverty. With an introduction by the Right Hon. David Lloyd George, 1912, p.301f 
Money based his arguments on the idea that the trade cycle was governed by factors inherent in the system itself. He, too, believed that man could never hope to reduce industrial production and economic transactions to machine-like regularity. Sudden shortages of material, bad seasons and natural disasters could seriously interfere with trade and commerce. New machinery and production method could leave multitudes of workers suddenly unemployed as had happened with the introduction of ferro-concrete in the building trade. Large scale financial difficulties of a whole state could seriously rock industry as they had done in the US in $1907^{852}$. Most significantly, however, modern trade and industrial production were by necessity international activities and thus depended upon not only favourable conditions within one's own country, but upon like circumstances around the world. Money listed the case of the ship-building industry to show how trade fluctuated internationally: due to no immediately discernible cause, the industry had receded by one-half between 1906 and 1909 in the major shipbuilding nations Great Britain, Germany and the US. "We get a picture of fluctuation so wide and so rapid", he said, "that we realise that the shipyard workers of the world are toyed with by circumstances over which they have no control" ${ }^{\prime 853}$.

Society, Money held, could not rely upon any alleged self-regulating forces of industry, the central policy propagated by laissez-faire liberalism. In its own interest, it must try to interfere with the negative consequences of the natural progression of industry and commerce in order to ensure as much regularity of employment and pay as possible. Work was indeed irregular; yet, maintenance must not be, if the worker was to be kept in usefulness and efficiency, Money argued. He enlisted the case of salaried personnel to demonstrate that steady jobs throughout the various stages of the trade cycle were in fact possible, even though white-collar workers, clerks and shop assistants ultimately lived off the same produce and the same transactions as manual labourers ${ }^{854}$. Through nationalisation Money hoped to achieve a degree of organisation in industry and commerce which would offset some of the determinant factors in economic life such as sudden bankruptcy or regional depressions.

Money foresaw no legal difficulties in disowning the private capitalist. In Hope for the Worker, he explained how modern society adhered to a mistaken concept of possession. Property literally meant "that which is proper to a person - that which is one's own". It implied the possibility of “owning”, of having and holding on one's person and of making it one's own by using it with one's hands or one's senses. If a man had a book which he intended to read, a picture he enjoyed looking

\footnotetext{
${ }^{852}$ Chiozza Money, Leo George, Insurance versus Poverty. With an introduction by the Right Hon. David Lloyd George, 1912, p.303

${ }^{853}$ Chiozza Money, Leo George, Insurance versus Poverty. With an introduction by the Right Hon. David Lloyd George, 1912, p.306f.

${ }^{854}$ Chiozza Money, Leo George, Insurance versus Poverty. With an introduction by the Right Hon. David Lloyd George, 1912, p.311
} 
at, a garment he wore to give him comfort, Money argued - then indeed, did he hold, enjoy, possess. "Such things are truly and literally property - things proper to the person who is their owner" ${ }^{\$ 55}$, he held. A portion of stock, a number of shares, a quantity of government bonds or a large piece of territory were an entirely different story. These were items for the greater part out of the actual possession and out of the actual control of their alleged owner. One could not hold and possess them in any real meaning of the word. Money contended that their ownership was imaginary, sanctioned de jure, but impossible de facto.

The same applied to industrial plants, he held, with their often vast grounds, multitude of buildings and, not least, with all the complicated machinery which by necessity had to be worked by groups or communities of workers and in conjunction with other suitable machinery. "No man can personally own a cycle factory", Money explained, "in the true sense that all the complicated machines are proper to his person, to be used by him. Indeed, it is impossible for a man to possess such an entity in any real sense of possession." 856 There existed things, Money argued, which essentially - through their inherent qualities and the nature of their use - could only be owned collectively by the persons who used them and worked with them. They included ideas and the means of collaboratively operated large-scale production. In some areas, Money believed, only the denial of individual ownership made civilised life possible ${ }^{857}$. He did not, however, demand the abolition of private property as such: "On the contrary, our aim should be to increase and enlarge personal property in its real sense - to make the possession of personal and intimate forms of wealth possible for everyone." ${ }^{958}$ Money's overriding concern in nationalisation, as in most other measures of social reform he proposed, was to rectify the Error of Distribution.

b) Nationalisation of Land as the Solution to the Problem of Housing

The area of housing constituted another field which Money believed should be taken over by the community. Besides entrusting the state with the ownership and management of the nation's industrial plants, Money thus also proposed to make it the main landlord of the nation. Through the appropriation by the government of large stretches of land Money hoped to solve the housing problem of industrial Britain. In 1901, eighty percent of the population lived in towns, and one tenth lived within the tiny area of the county of London. Money proposed to buy up, at a very low price,

${ }^{855}$ Chiozza Money, Leo George, Hope for the Worker, 1913, p.27

${ }^{856}$ Chiozza Money, Leo George, Hope for the Worker, 1913, p.24

${ }^{857}$ Chiozza Money, Leo George, Hope for the Worker, 1913, p.27

${ }^{858}$ Chiozza Money, Leo George, Hope for the Worker, 1913, p.29 
the vast deserted countryside in order to rehouse the population in model villages such as existed, for instance, in Bournville 859 . "We must see to it that the demand for houses, the primary demand of civilised man, is answered not by the speculative builder, but by the nation itself," 860 he wrote. Money recommended that, for reasons of practicability, the municipalities be given adequate funds and be entrusted with organising and supervising local housing schemes.

He disagreed with land reform plans like those proffered by Stewart Headlam who proposed to seize private profits derived from rent for the community by way of a tax on land values. For Money, nothing short of appropriating the land itself would do. Simply to tax land at its renting or selling value as some land reformers postulated would not, Money believed, solve either the land question or the housing question. "There is only one effective way in which the community can keep in its own hands the 'unearned increment' arising from the enhanced value of land created by the presence and work of the community" he believed, "and (...) that effective way is for the community to own the land." $" 861$ The housing question was a national one and thus demanded concerted national effort and the use also of national capital.

By contrast to other reformers with an interest in housing discussed in this thesis, Money did not, however, jump on the band wagon of the back to the land movement. He did not subscribe to a mythical image of rural England. Nor did he believe that the state should use the newly appropriated land to interfere with the now industrialised economy and revive the agricultural sector. Cheap imports and the use of machinery in farming had left agriculture less profitable and less labour-intensive than in pre-industrialised times, he reported. A return to a predominantly agricultural economy was therefore unrealistic.

Besides, although he expected beneficial results from healthy housing in the countryside for the nation's children ${ }^{862}$, Money warned against deluding oneself about the reformability of the degenerate urban adult. "We must not believe", he admonished his readers, "that mature and debilitated town-dwellers can be planted out in rows to gain a living by entire devotion to agriculture. We can hope for but little from farm colonies for the unemployed." ${ }^{863}$ In Money's mind, the nationalisation of land served the sole purpose of solving the housing problem of Great Britain and ensuring that every member of the population lived in decent accommodation.

\footnotetext{
${ }^{859}$ Chiozza Money, Leo George, Riches and Poverty, 1905, p.207

${ }^{860}$ Chiozza Money, Leo George, Riches and Poverty, 1905, p.215

${ }^{861}$ Chiozza Money, Leo George, Riches and Poverty, 1905, p.204

${ }^{862}$ Chiozza Money, Leo George, Riches and Poverty, 1905, p.226

${ }^{863}$ Chiozza Money, Leo George, Riches and Poverty, 1905, p.226
} 
c) Insurance and Pension Schemes as a Safeguard against Impoverishment

Nationalisation of all means of large-scale production and of land formed the most fundamental and radical step in the fight against poverty and for the progress of civilisation, Money believed. But it could not in itself solve all aspects of the social problem. Nationalisation in Money's eyes had to be complemented by a series of redistributive measures designed, first, to assist those who, for whatever reason, could not earn their own keep and, secondly, to equal out some of the lingering injustices of the hitherto extant economic and social system.

Money identified two groups among the adult poor who urgently needed additional support from the community. One group were those among the mass of British labourers who were constantly at risk of losing their jobs, the semi- and unskilled, the casual labourer, the seasonal worker and those employed in trades subject to great fluctuations. Even under a system of national ownership and management, Money stated, there could be no such thing as security of tenure of employment for the majority of the British people. Jobs varied with the seasons, the weather, with fashion or with the state of international trade. Money calculated that an average workman lost eight to ten weeks of wages a year due to periods of non-employment or short time work ${ }^{864}$. For the winter of 1904/05, he estimated that about five to six hundred thousand men and women had been out of work for a considerable length of time. Against such loss of income, some could guard partially by joining private benefit schemes and trade union-run insurance programmes; many, however, could not afford regular contributions to such funds ${ }^{865}$.

In Insurance versus Poverty, Money therefore strongly advocated Lloyd George's compulsory unemployment insurance as a safeguard on a national level against sudden loss of maintenance among workers. "The first duty of a civilisation", he argued, "is to pool its resources and its risks that no man, or set of men, shall be made to endure the consequences of an irregularity which civilisation cannot prevent." ${ }^{\prime 866}$ Industrial life constituted a national affair and the well-being and efficiency of the workers lay in the interests of all who contributed to and benefited from the economic system of Great Britain. In Money's opinion, a state-run insurance system as safeguard against sudden unemployment formed part of the "never ending struggle" 867 for civilisation against the destructive forces of nature.

Secondly, Money felt particularly concerned about the high rate of pauperism among the elderly. Using data on poor relief in England and Wales in 1891, Money showed that one in eighteen out of

\footnotetext{
${ }^{864}$ Chiozza Money, Leo George, Riches and Poverty, 1905, p.26

865 Chiozza Money, Leo George, Riches and Poverty, 1905, p. 111f.

${ }^{866}$ Chiozza Money, Leo George, Insurance versus Poverty. With an introduction by the Right Hon. David Lloyd George, 1912, p.312

${ }^{867}$ Chiozza Money, Leo George, Hope for the Worker, 1913, p.2
} 
the total population, but one in three out of the population aged sixty-five and over, were in receipt of some form of poor relief ${ }^{868}$. Based upon the above data he reckoned that, in 1905, the actual need among the aged was about double the help given out under the Poor Law, amounting to about 1.2 million aged citizens in dire poverty. In Money's estimate, the full wage-earning capacity of the average skilled workman began at twenty-five to thirty and ended at fifty-five at the latest. "After 50-55 the age factor (...) begins to tell, and the workman trembles at thought of the future. Each grey hair is a deadly enemy to his livelihood." 869

In Money's opinion, as in the case of the unemployed, the community should therefore take upon itself responsibility for its elderly members. Through no fault of their own, but simply because of how capitalism functioned, the aged workers found themselves unable to earn their own keep, and reduced to a state of undeserved pauperism. Before Lloyd George's Liberal insurance programme, Money proposed in Riches and Poverty to make a universal pension of about $5 \mathrm{~s}$ a week claimable by those aged sixty-five or over who could not muster an income of more than $£ 1$ a week. Assuming that figure to amount to about 1.2 million aged citizens as he had calculated from Poor Law data gathered since $1891^{870}$, Money believed the burden on society to be light compared to the accumulated wealth of Great Britain. "With the gross assessment to Income Tax at $£ 900.000 .000 ”$, he wrote, "the expenditure of $£ 15.000 .000$ on a small provision of the aged strikes one not as extravagant, but as an exceedingly modest proposal to mitigate the evils of the Error of Distribution." ${ }^{871}$ Care for the aged, he believed, constituted a communal duty and formed an integral part of civilised life.

\section{d) Equality of Sacrifice - A Reform of the System of Taxation}

In order to finance his proposals of national insurance programmes and pension schemes in an attempt to rectify the Error of Distribution, Money propagated a reform of the tax system. Without adequate funds to realise his proposals and impose new policies, he believed, the state would necessarily remain weak and inferior to private capital. Money proposed to start with a remodelling of the income tax.

The present system of proportional taxation based upon Adam Smith's teachings distributed the burden unfairly among the poor and the wealthy and left too many loop holes for evasion. At

${ }^{868}$ Chiozza Money, Leo George, Riches and Poverty, 1905, p. $264 \mathrm{f}$.

${ }^{869}$ Chiozza Money, Leo George, Riches and Poverty, 1905, p.271

${ }^{870}$ Chiozza Money, Leo George, Riches and Poverty, 1905, p.265

${ }^{871}$ Chiozza Money, Leo George, Riches and Poverty, 1905, p.275 
present, from a yearly income of $£ 160$ upwards, the state took ten percent of the annual sum and thereby imposed a crushing burden upon those who owned little, while to the rich the deduction constituted a light matter of no consequence. Money pleaded for "equality of sacrifice" 872 by reforming the present system in three respects.

Firstly, Money called for a substitution of gradation for the present system of roughly proportional taxation and to levy heavy duties upon high incomes above $£ 1000$ a year ${ }^{873}$. Secondly, he advised to distinguish in the matter of taxation between incomes derived from property and those earned by labour. A man who earned $£ 400$ a year by hard work and was taxed at the same rate as one who earned $£ 400$ by house letting, rents and speculation, Money believed, felt rightly irked. "These are real grievances which should be removed", Money held, "and I urge that if we take the trouble to remove them, the Income Tax will be universally recognised as a just instrument of taxation." 874 The exemption limit for increment derived from shares, stock and landed property should in Money's view be lowered from $£ 160$ to but $£ 50$ and burdened with a rate of five percent, more if the income exceeded $£ 1000$ per annum. Thirdly, he demanded that investment abroad be taxed at a heavy rate as it drained capital from home industries and domestic trade.

In addition, Money recommended an abolition of food customs on basics such as tea and sugar. Taxes on food stuff constituted heavy loads upon the poor and ran counter to the principle of ability. The poor should be taxed solely for their luxuries such as tobacco and alcoholic beverages ${ }^{875}$. Only the comfortably off should be burdened with the upkeep of the state as agent of the community. The new system of taxation could further be complemented by revised death duties. Money proposed to increase the percentage levied upon the estate values as well as to decrease the range of estate value per tax rate. Only the protection of the state made the safe inheritance of another man's property possible at all, he argued. The community thus had a justifiable claim to a certain share of the wealth passed on $^{876}$. His new system of gradation for death duties, he calculated, would for the year 1903/04 have more than doubled the income from the above source. Money considered his proposals a fair way of fighting some of the worst excesses of the Error of Distribution. If reformed in the proposed manner, Money estimated, funds derived from income tax and death duties alone would suffice to introduce reforms like the nationalisation of industries or old age pensions ${ }^{877}$.

\footnotetext{
872 Chiozza Money, Leo George, Riches and Poverty, 1905, p.278

873 Chiozza Money, Leo George, Riches and Poverty, 1905, p.301

${ }^{874}$ Chiozza Money, Leo George, Riches and Poverty, 1905, p.301

875 Chiozza Money, Leo George, Riches and Poverty, 1905, p.279

${ }^{876}$ Chiozza Money, Leo George, Riches and Poverty, 1905, p.308

877 Chiozza Money, Leo George, Riches and Poverty, 1905, p.310
} 


\section{The Children: The Nation's Future}

It fits in with Money's faith in the state as the trustee of the community that he proposed to entrust the government with its most important and valuable assets in the evolutionary process, the children of the nation. Infants were born into a family and their immediate carers and role models naturally were their parents and older siblings. Yet, a child belonged not only to its relatives, Money argued. It was also "an integral part of the nation, and entitled to the care of a country which desires strong and healthy citizens" ${ }^{\prime 78}$. At birth, Money believed, a baby constituted an "unsullied page", physically as well as mentally, "upon which we may write what we will" ${ }^{\text {" } 79}$. It was therefore extremely dangerous that the nation let about 400.000 of the 1.2 million newborns per year grow up in conditions of extreme poverty and deprived of a proper chance in life: "One third of the newborns go to feed the ranks of misery and to form, such of them as do not perish in infancy, the raw material of the social problems of those who are to follow us." ${ }^{880}$ Malnutrition, abuse, disease and exposure left them enfeebled and physically degenerate, unequipped to fight for themselves in a labour market built upon the premises of virility and energy.

Money argued that it was absolutely essential to the nation's well-being and progress that it supported and protected future citizens from the very beginning of their lives. He called for the state to start taking care of its children with the mother's pregnancy. Money recommended a scheme instituted by the medical officer of health at St. Pancras, J. F. J. Sykes. Faced with 130 new births per week in an extremely poor neighbourhood, Sykes had built up an army of women inspectors who visited necessitous cases and gave advice on hygiene, breast feeding, infant care and nutrition. All mothers in confinement received by mail a leaflet with information and contact addresses. The women inspectors alerted the Charity Organisation Society and local charitable agencies to cases in need of long-term help. A system along such lines which took care of mothers and infants alike from the moment of birth, Money held, was required "if we are to rescue the poor children of the new generation" $" 881$ and to ensure national growth.

As degeneracy and early death often resulted from neglect, overwork and accidents during pregnancy, Money postulated to prohibit nationally the employment of married women in factories and workshops. In the six months around a child's birth, they should be prevented from working even in home employment. In Money's eyes, the liberty of the individual woman counted less than

\footnotetext{
878 Chiozza Money, Leo George, Riches and Poverty, 1905, p.171

879 Chiozza Money, Leo George, Riches and Poverty, 1905, p.157

880 Chiozza Money, Leo George, Riches and Poverty, 1905, p.160

881 Chiozza Money, Leo George, Riches and Poverty, 1905, p.167
} 
the protection and well-being of the unborn or new-born child who would grow into a future citizen of the British nation. The existing legislation which prohibited the employment of women in factories for four weeks after giving birth was downright useless, he pointed out. It was simply not enforceable as long as there did not exist a national organisation of industry and no security of income. Nothing could prevent a starving mother to seek work with a new employer immediately after confinement without declaring her condition. "There is only one proper place of work for the married woman", Money held, "and that is her home." ${ }^{882}$ He cited the case of the Jewish community in London which produced healthier and stronger offspring than their gentile neighbours. Money ascribed the result to the fact that in Jewish custom, married women looked after their families and houses and did not hold outside employment ${ }^{883}$.

Money was concerned that the children receive the best possible care for their bodies as well as their minds. For preschoolers, he suggested a municipal milk service. Older children should be cared for physically via the agency of the school. Money recommended school meals and the handing out of appropriate clothing. The school should also teach the child basic hygiene and introduce weekly baths. School doctors should screen the children's general health and their progress over the years. Money brushed off arguments that school meals interfered with family responsibility and demoralised the parents. "In cases of defective nourishment, the child must be fed whatever the character of the parent" ${ }^{\prime 884}$, he wrote. Sixteen per cent of elementary school children, he estimated, were seriously underfed. It was from reasons of purest common sense and selfprotection that the state must, in such cases, intervene ${ }^{885}$. "[T]he parents are often already thoroughly demoralised", he explained, "and (...) their demoralisation in the great majority of cases has resulted from the conditions imposed upon them from their births by our social system." ${ }^{886}$ Money was unprepared to let the parents off lightly. He suggested drastic punishments for neglectful mothers and fathers. Yet, he expected to derive great results from the state's involvement with its children: "Nothing, in my opinion, is so likely to encourage the feeling of parental responsibility, and to shame careless mothers, as the knowledge that at school the child is regarded as a valuable commodity." 887

In addition to caring for the child's physical well-being, the state should also provide for its mind and education. "They only mock the masses of the people who flatter them in the belief that they

\footnotetext{
${ }^{882}$ Chiozza Money, Leo George, Riches and Poverty, 1905, p.169

${ }_{883}$ Chiozza Money, Leo George, Riches and Poverty, 1905, p.169

${ }^{884}$ Chiozza Money, Leo George, Riches and Poverty, 1905, p.179

${ }^{885}$ Chiozza Money, Leo George, Riches and Poverty, 1905, p.180

886 Chiozza Money, Leo George, Riches and Poverty, 1905, p.181

${ }^{887}$ Chiozza Money, Leo George, Riches and Poverty, 1905, p.179
} 
have power while they deny their children education," 888 he wrote. The aim of schooling, Money argued, should be to prepare the child for its future role in society. Money postulated that through education, every child should be given an equal chance in life. At present, the children of the working classes were trained to be "bottom dogs" 889 , not to govern themselves, but to be governed by their alleged social superiors. Multitudes of the under-aged went to work in factories and workshops in order that the few could enjoy further education and study how to command the toiling masses.

Money blamed the present system of elementary schooling for cementing the social status quo. In his opinion, the working classes had gained little from the introduction of compulsory schooling with the Forster Education Act of 1870 and the Education Act of 1903. Statistics compiled by the Board of Education showed attendance figures at elementary and higher elementary schools for the year 1906-7 to decrease from 623.000 children aged eleven to but 67.811 aged fourteen and a very meagre 507 scholars aged sixteen and above ${ }^{890}$. Of the 691.000 children of 14 years of age in 1906, only 248.050 or 35.9 percent attended school; the figure included students at night schools. The great majority of children, Money found, were even in 1906, years after the introduction of the earliest education bills, withdrawn from school by their parents at the earliest moment allowed by the law ${ }^{891}$. To the larger part of the population, schools could in the relatively short span of attendance merely provide "a few blunt tools - a limited vocabulary, the power to read indifferently well, a rule-of-thumb acquaintance with a few arithmetical processes, and for the rest, some exceedingly vague ideas about kings and battles, seas and countries, and the ancient Jews" ${ }^{\$ 92}$.

Money showed himself concerned about Britain's international competitiveness while so much "national material" $" 993$ went to waste. Money called for an education which rendered man "not only strong, but artful, not only intelligent, but cunning,(...) not only fit to work, but fit to bargain" ${ }^{\prime 894}$ - all of which were requirements of the modern labour market. Schooling, Money demanded, should prepare the individual for taking up its rightful place in society and enable it to perform the civic duties proper to its station. Ideally, it should equip the child with the skills necessary to contribute to the social, cultural and economic progress of the nation.

\footnotetext{
${ }^{888}$ Chiozza Money, Leo George, Hope for the Worker, 1913, p.50

889 Chiozza Money, Leo George, Hope for the Worker, 1913, p.49

${ }^{890}$ Chiozza Money, Leo George, Things that Matter. Papers upon subjects which are, or ought to be, under discussion, 1912, p. 211

${ }^{891}$ Chiozza Money, Leo George, Things that Matter. Papers upon subjects which are, or ought to be, under discussion, 1912, p.210

${ }^{892}$ Chiozza Money, Leo George, Things that Matter. Papers upon subjects which are, or ought to be, under discussion, 1912, p. 216

${ }^{893}$ Chiozza Money, Leo George, Things that Matter. Papers upon subjects which are, or ought to be, under discussion, 1912, p.218

${ }^{894}$ Chiozza Money, Leo George, Riches and Poverty, 1905, p.174
} 
As a first step, Money suggested to raise the school leaving age to sixteen as was already done in Germany and to introduce compulsory continuation classes. Also with a view to the German system of education, Money recommended to include the study of sciences in the curriculum as a matter of course; only through universal knowledge and understanding of the means of producing wealth, he believed, could society hope to put its inventions to full use, to permanently escape natural poverty and to maintain its international supremacy ${ }^{895}$. School should in Money's opinion include swimming lessons and physical drill in order to improve the nation's health and physique. Above all, however, school should teach to every child the basic lessons of social behaviour and co-operation. With everything taught in school, he demanded, should be associated the moral principle that a child should do harm to no one ${ }^{896}$. By such a system, Money hoped to produce a population which was "clean, neatly clad, healthy, well-nourished, upright, self-respecting and therefore respectful of others, feeling its strength in every limb, well mannered, capable of lucid expression"

Within the limits of the traditional role models assigned to the sexes by Money, he included women in his desire for better training and greater chances in life. In his eyes, girls should be prepared in school chiefly for their future roles as house keepers and mothers. Money proposed to introduce classes in cooking, child care, domestic economy and hygiene. ${ }^{898}$ To leave the training of girls, the mothers of the future, to the soulless and brutal machinations of competitive industry and commerce, he believed, was to deliver the nation to moral and physical decrepitude.

Money proposed to make the costs of continuation schools an imperial charge ${ }^{899}$. An estimated two million continuation scholars would, Money believed, have to be provided for at an average cost of $£ 3$ per head per annum. At an annual national income of 2,000,000,000 Money considered the price of such an undertaking to be insignificant "either in relation to our wealth or in relation to the enormous benefits it would confer" ${ }^{\prime 900}$. He proclaimed the costs to be not so much an expenditure than an investment - an investment in the future of the British nation, her cultural stock and material wealth. Continuation classes, he assured his readers, would "in the course of not many years, (...) yield interest a thousand-fold in raising alike the standard of life and the quantity and quality of British material production" ${ }^{\prime 01}$.

${ }^{895}$ Chiozza Money, Leo George, Riches and Poverty, 1905, p.185; see also Chiozza Money, Leo George, Things that Matter. Papers upon subjects which are, or ought to be, under discussion, 1912, chapter on "The Mockery of Education"

896 Chiozza Money, Leo George, Riches and Poverty, 1905, p.183

897 Chiozza Money, Leo George, Riches and Poverty, 1905, p.183

898 Chiozza Money, Leo George, Riches and Poverty, 1905, p.165

899 Chiozza Money, Leo George, Things that Matter. Papers upon subjects which are, or ought to be, under discussion, 1912, p.225

900 Chiozza Money, Leo George, Things that Matter. Papers upon subjects which are, or ought to be, under discussion, 1912, p.226

901 Chiozza Money, Leo George, Things that Matter. Papers upon subjects which are, or ought to be, under discussion, 1912, p.226 
Money's point of departure for his plans of social reorganisation was the welfare of the British nation and concern for her social, cultural and economic growth. He believed that Britain's social problems held her back in her progress in the evolutionary process. He traced those problems back to faults in the economic set-up of the nation and thus placed a particular emphasis on a reform of the country's economic machinery an his attempt to tackle the social question. Money lamented the inefficiency of the present system of untamed capitalism where labour was wasted and where the Error of Distribution held back the majority of the population in the development of their capacities. Money's proposals for a solution to the social question took him a long way from his ideological origins as an advocate of free trade. He advocated the nationalisation of all means of large-scale production in order to set up a central organisation of industry and the workforce. Only the nationwide organisation of industry would ensure the best possible application of labour to the best available means of production. In addition to nationalisation, Money advocated community- (i.e. state-)run, social security measures such as unemployment insurance, old age pensions and some measures of care for infants and growing children. Central to his thought was also the idea of a proper education under government responsibility for every member of society which would enable the individual to fulfil his or her role as citizen and to contribute his or her share to the constant struggle against nature for comfort and civilisation. His proposals for a reform of the social and economic set-up show that Money believed in a strong state which acted as the agent of the community and representative of the nation's best interests and which held power of coercion over the individual in order to enforce measures necessary for national growth and well-being..

The following chapter explores the social thought of a thinker who falls into the category of antiChristian, the last of the four categories chosen for this study. In the ideas of the rationalist John Robertson, we shall encounter many parallels to the theories and proposals of Leo George Chiozza Money. Like Money, Roberston held a biologistic view of mankind and of society and justified his demands for social reform with his concern for the nation's progress and well-being. By contrast to Money, however, Robertson remained staunchly within the framework of New Liberal social reformism with his own proposals for a solution of the social question. 


\section{Anti-Christian Socialist}

\section{Chapter 8 - John Mackinnon Robertson on Social Progress}

\section{Biographical Data: John Mackinnon Robertson}

The last thinker to be examined for the purposes of this study is John Mackinnon Robertson. He serves as an example of a social reformer who was anti-religious and held that the social situation of Great Britain was some degree due to the impact of Christianity on British society over the past centuries. Robertson firmly believed that the social question could be solved only if measures designed to fight poverty and to stabilize the economy were accompanied by a rethinking in society which would, among other things, put a check on the corrupting influences of established religion. John Mackinnon Robertson was born on November 14th, 1856, at Brodick on the Isle of Arran as the son of John Robertson, a crofter, and his wife Susan Mackinnon. He left school at the age of thirteen to work as a railway telegraph clerk and law clerk. Around 1870 he moved to Edinburgh combining his geographic move with a career change into journalism; by 1878, we find him firmly established as leader writer of the Edinburgh Evening News, an organ of advanced radicalism.

In Edinburgh, Robertson made first contact with the secularist movement and became an ardent supporter of the atheist MP Charles Bradlaugh who at the time stirred up wide publicity by refusing to take the oath on taking up his seat in Parliament. Liberating himself from the shackles of established Christianity may have been a difficult task for Robertson, as his biographer Odin Dekkers suggests ${ }^{902}$ : Robertson grew up in an apparently very religious atmosphere, and his parents were consequently deeply pained by his break with traditional faith. Nonetheless, doubt seems to have beset him as early as his teenage years. As he wrote to a friend in 1906: 'I gave up the 'divine' notion in my teens: when I came to probe thoroughly the 'human' problem I was long past attaching any meaning whatever to the 'divine' conception."

\footnotetext{
${ }^{02}$ Dekkers, Odin, J. M. Robertson: rationalist and literary critic , 1998, p.5

903 As quoted in Dekkers, Odin, J. M. Robertson: rationalist and literary critic, 1998, p.4
} 
Robertson quickly made a name for himself within the secularist movement as an excellent platform speaker and capable exponent of the secularist cause. In 1884, he was called to London by the leading secularist and social reformer Annie Besant ${ }^{904}$ to become assistant editor of Bradlaugh's rationalist paper National Reformer. Upon Bradlaugh's death in 1891, Robertson succeeded to the editorship of the National Reformer until the paper closed down in 1893. During the first three years of his stay in London, Robertson took up lodgings with Annie Besant. There developed an intense working relationship between the two, Robertson contributing articles to and editing not only the National Reformer, but also Besant's publication Our Corner. Under Robertson's influence, Besant moved into the direction of socialism. In her Autobiography she credited her lodger and coworker with persuading her that "the case for Socialism was intellectually complete and ethically beautiful" 905 .

Secularism and freethought were constants in Robertson's life. He served as a lecturer to the South Place Ethical Society from 1899 into the 1920s, co-founded the anti-ecclesiastical Rationalist Press Association which published cheap popular editions of books on natural sciences and freethought, and taught courses in political economy and sociology at Bradlaugh's headquarters, the Old Street School of Science, where he presumably met his co-lecturer Stewart Headlam. Robertson published several important works on the history of freethought. His A Short History of Freethought. Ancient and Modern appeared first in 1899 and went through several editions greatly revised and enlarged during Robertson's lifetime; it remained an important work of reference for historians of the freethought movement well into the twentieth century ${ }^{906}$.

Robertson extended his interests to include questions of social reconstruction and of ethics during the early 1880s. In tackling the problems of industrial society he was not driven primarily by a sense of compassion or righteousness, but by an insistence on logic and science. A student of political economy and sociology, Robertson held that to allow the present divide into a few very rich and a mass of very poor to continue ran diametrically counter to the laws of political and economic science and constituted an affront to common logic. Yet, he cautioned his contemporaries that socialism was a "matter of degree" $" 907$. He rejected violent Marxist ideology on the grounds that

904 Annie Besant (1847 - 1933) was a prominent social and women's rights activist. Besant was a leading member of the National Secular Society and a close colleague of Charles Bradlaugh. She was also an active member of the Fabian Society. Besant played a decisive role in setting in motion the Bryant and May match girls strike of 1888 . In later life, she moved into Theosophy and later Hinduism. She died in India in 1933.

905 Besant, Annie Wood and Geoffrey West, Annie Besant: An Autobiography, 1893, as quoted in Dekkers, Odin, J. M. Robertson: rationalist and literary critic, 1998, p.18

906 A Short History of Freethought. Ancient and Modern, and the sequel A History of Freethought in the Nineteenth Century have both been reprinted in 1969; see also A Short History of Morals, reprinted in 1971. Robertson, John Mackinnon, A history of freethought ancient and modern, to the period of the French revolution, 1969; Robertson, John Mackinnon, A history of freethought in the nineteenth century, 1969; Robertson, John Mackinnon, A short history of morals, 1971

907 Robertson, John Mackinnon, The Great Budget, 1910, p.45 
he found it un-reason-able. He warned against the doctrine of a revolutionary social explosion which by its very nature would be uncontrollable and could not be directed. Besides, he held, the notion of "a violent triumph of one class over another, a setting of the foot of poverty in the neck of wealth" ${ }^{908}$, was incompatible with both the moral as well as the economic stability of socialism and endangered through its propaganda of violence and hatred the whole undertaking of social reform.

Robertson favoured practical, manageable reform through existing institutions and a step-by-step transformation of society over distant utopias, however perfect and appealing they might appear. The attitude is reminiscent of the writings of William Booth and Henrietta Barnett who also preferred practicable, hands-on socialism to dream visions of a just society, although as we shall see in the course of this chapter, in his reform proposals, Robertson was prepared to alter the structure of society and upset the social balance much more fundamentally than either of the two. In view of his belief in gradualism, it comes as no surprise that Robertson was a life-long sympathiser of the Fabian Society, although he never actually became a member.

Robertson felt politically at home in the progressive wing of the Liberal Party among the exponents of New Liberalism. To him, the boundaries between socialism and liberalism were not a matter of political party allegiances, but of the degree of radicalism exhibited by individuals. In Robertson's eyes, socialists and liberals alike joined in a common war on privilege. He considered socialism to be but a further development of liberalism: "All that is conceivably workable in the proposals of British Socialists", he claimed, "while society remains broadly what it is, is only a further development of plans already laid down by Liberalism." 909 He called to socialists and liberals to combine their strengths and work together in order to achieve necessary reforms.

Robertson urged his fellow-party men to reconsider the aims of liberalism. He proposed to replace the time-honoured party principle of "war on privilege" by the more modern phrase "equality of opportunity"910. The main instances of privilege in modern industrial Britain, he held, could be found in the sphere of social inequality, and it was this age-long contrast between wealth and poverty that he believed the Liberal Party should fight against ${ }^{911}$. Liberalism to Robertson meant a movement of "liberation, of sympathetic beneficence, of social readjustment and reconstruction" His membership in the progressive discussion group Rainbow Circle from 1899 onwards offered him a welcome platform among like-minded intellectuals to test and develop his ideas both on the nature and course of liberalism as on the proper set-up of society.

In 1906, Robertson entered Parliament as Liberal MP for Tyneside, a position he would not

\footnotetext{
908 Robertson, John Mackinnon, The Meaning of Liberalism, 1912, p.142

909 Robertson, John Mackinnon, The Meaning of Liberalism, 1912, p.140

910 Robertson, John Mackinnon, The Future of Liberalism, 1895, p.15

911 Robertson, John Mackinnon, The Future of Liberalism, 1895, p.15

912 Robertson, John Mackinnon, The Meaning of Liberalism, 1912, p.28
} 
relinquish until 1918. In 1915 he was appointed Parliamentary Secretary to the Board of Trade, but had to give up the post in 1918, when Asquith formed his coalition government. In the final years of his life, Robertson became increasingly involved with foreign policy, supporting the cause of the Egyptians and denouncing British treatment of India.

Robertson died of a stroke on January 5th, 1933 in his own home.

\section{The End of Human Evolution: Social and Cultural Growth}

a) Progress as the End of Human Evolution

At the basis of Robertson's social thought in a way similar to Chiozza Money's lay a belief in the absolute value and endless possibility of progress. By progress Robertson meant the ever-increasing development and expansion of man's material, social and cultural resources. It was, in Robertson's eyes, the ultimate end of human existence. Like Money, Robertson adhered to the biologistic view that man as much as any other animal creature in the universe was subject to an ongoing process of evolution, a struggle against the forces of nature in which man could hope to succeed only through a continual improvement of his civilising capacities - in other words, through working towards progress.

Evolutionary processes in the animal kingdom, Robertson wrote, dealt with the physical survival of a species. In a constant struggle for existence, the physically fittest triumphed and thereby ensured the continued existence of their kind. Man, too, had once been part of this brutal process of physical selection and elimination ${ }^{913}$. But by contrast to beasts, Robertson pointed out, man was equipped with the vital tools of intellect and creativity, and in the struggle for survival, with their help, he had triumphed over nature and begun to develop the first grains of modern civilisation. Here, then, Robertson detected the fundamental difference between animal and human evolution. Through his superior mental and creative skills, man had managed to work himself out of a struggle for sheer existence. The physical continuance of the human race in the biological world was ensured. The new challenge of human evolution now consisted in the development of men's higher faculties, of civilisation. The new maxim of human evolution, in Robertson's words, read "struggle against the

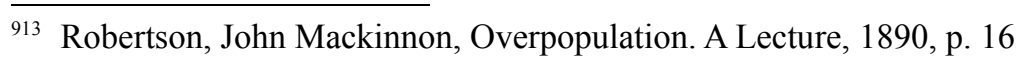


struggle for existence" 914 .

In Robertson's eyes, social reform thus constituted a dictate not only of common sense and logic, but also of human evolution. He compared the nineteenth century liberal formula of unlimited competition to the Darwinian maxim of survival. The very idea of laissez faire ran counter to social and cultural progress, Robertson argued ${ }^{915}$. Survival of the fittest under physically hard conditions, whether in nature or under a system of unrestricted competition in nineteenth century British society, usually meant survival of the strongest in body, not in mind or morality ${ }^{916}$. Those men and women were the fittest for the life of blind instinct only, he believed, for the kind of skill that overreached one's neighbour and insisted on personal advantage. Under the present system of laissez faire, "we are producing plenty of brains fit for stock-broking, for buying cheap and selling dear, for making bad work look good", he elaborated, "for producing inferior literature and art, windy religion and shallow philosophy." $" 917$

Of course, Robertson conceded, some of the skills thus developed were essential to the running of a successful economy and a sound government. But he insisted that national growth depended upon cultural progress as much as on industrial expansion. Great inventions, ground breaking discoveries and great art were the outcome of time and great brains, not of supply and demand. "Great men do not multiply in the ratio of the increase of population struggling for existence" ${ }^{\text {"918, }}$, Robertson held. Conscious progress under a scientific morality such as desired by Robertson worked under different conditions than progress of a Darwinian kind under a system of purely instinctive morality.

The new stage of human evolution no longer aimed at survival, but at cultural development and the growth of civilisation. Robertson based his argument on a very broad definition of culture and civilisation. Culture was not, he laid down, knowledge of a prescribed body of literature, a taste for the arts, a certain standard of living, a clearly defined set of customs and manners. It was not a state of refinement attainable only by the leisured and rich. Robertson defined culture as "the doing something which expands the powers and opens the way to new activity"919. To him, it meant the cultivation of mental and physical faculties, their exercise and expansion, and the enjoyment of their progress and activity ${ }^{920}$. In Robertson's eyes, culture formed an active and developing function of human life. With its changeability and its capacity of growth and expansion, it constituted the prime agent of national growth, in terms of its degree of civilisation as well as its economic success. It had

\footnotetext{
914 Robertson, John Mackinnon, Overpopulation. A Lecture, 1890, p. 17

915 Robertson, John Mackinnon, The Meaning of Liberalism, 1912, p.64

916 Robertson, John Mackinnon, Overpopulation. A Lecture, 1890, p.17

917 Robertson, John Mackinnon, Overpopulation. A Lecture, 1890, p.17

918 Robertson, John Mackinnon, Overpopulation. A Lecture, 1890, p.17

919 Robertson, John Mackinnon, Culture and Action. A Discourse, 1897, p.77

920 Robertson, John Mackinnon, Culture and Action. A Discourse, 1897, p.69
} 
started off the Industrial Revolution as much as the revolution in scientific knowledge since Newton, Leibniz and Darwin, both of which had brought society forward in its progress towards perfection to an unprecedented degree.

Robertson detected a great solvent of prejudice in culture as defined above. "As travel and intercourse with foreigners are sure correctives of the subrational antipathies of race", he declared, "so the rubbing against ideas, even at random, is on a large scale irresistibly destructive of our oldworld superstitions, our class jealousies, our local vanities, our social bigotries, and even to some extent of our hypocrisies." ${ }^{921}$ In Robertson's opinion, it was of immense importance for the future of the entire nation that each member of society be exposed to the world of ideas, to culture, and be enabled to exercise his or her mental faculties and creative skill freely and to the fullest possible extent.

b) Christianity: The Stumbling Block of Progress and Social Evolution

His belief in the world of ideas helps to explain Robertson's antipathy towards established religion. He believed that Christianity had in its long history proven an impediment to the growth of civilisation. In Robertson's eyes, Christianity was not conducive to new developments in the sciences and the arts of mankind. He cited the example of the Byzantine Empire to illustrate his point: in the thousand years of its existence, Robertson could find no appreciable progress in the arts, philosophy or medicine among the Byzantines. "Here, then, Christianity had had the fullest conceivable chance to prove its civilising or progressive powers", Robertson underlined, "and it proved a more absolute failure than we can trace in any previous history." 922 The few developments in arts and science which did take place in the millennium Robertson credited to the Muslim religion. With a certain glee he pointed out that civilisation could proceed further and faster under a religion other than the allegedly humanising and civilising Christian faith $^{923}$, a religion Christians considered backward and barbaric.

By contrast to the Christian thinkers examined in the present study who placed great hopes on their religion as civilising agent in the modern world, Robertson rejected the idea of Christianity as a moral and cultural catalyst. On the contrary, to Robertson Christianity appeared a destructive force. He believed, for instance, that the spread of Christianity within its bounds had caused the collapse of the Roman Empire in antiquity. Unlike the civic religion of the early Romans, he held, other-

\footnotetext{
921 Robertson, John Mackinnon, Culture and Action. A Discourse, 1897, p.79

${ }_{922}$ Robertson, John Mackinnon, What has Christianity Done, 1897, p.4

${ }_{923}$ Robertson, John Mackinnon, What has Christianity Done, 1897, p.5
} 
worldly Christianity had turned men's thoughts and actions away from social and political problems of their times. It had made them believe in a better world in the hereafter, where social wrongs would be righted and injustices compensated for, "and so [had put] everything in such a state as made the Empire fit to come to an end"924.

In Robertson's eyes, Christianity was a violent and disruptive religion, hostile to peace, culture and the growth of civilisation. He pointed to the many armed conflicts and outbreaks of violence committed in the name of religion. The crusades, the inquisition, massacres among unbelievers, religious wars and witch hunts had cost thousands of lives and caused misery for millions ${ }^{925}$. Nor was Robertson prepared to credit Christianity with helping to abolish slavery in antiquity as it prided itself in doing. The ancient system of slavery came to an end not thanks to Christian teachings, but with the collapse of the Roman Empire, he argued; moreover, the medieval feudal system of serfdom in the thoroughly Christianized Western world constituted but a revival of slavery under a different name on yet a larger scale ${ }^{926}$.

For Robertson, religion constituted a workaround of ancient civilisations which sprung from ignorance and superstition and which would inevitably give way to a more rational view of the world in the face of scientific discoveries and the increase of knowledge. He held that religion and any concept of the supernatural originated in man's inability in earlier times to fathom scientifically the many mysterious phenomena of his environment. Failing to grasp the simple laws and processes of nature which ruled everyday life, man had resorted to explaining his existence as caused and controlled by quasi-human extra-natural personalities ${ }^{927}$. Robertson was convinced that the immense increase in scientific knowledge since the middle ages, and especially during the eighteenth and nineteenth century, would gradually free man of these intellectual expedients and liberate him from the constraints of religious dogma and ecclesiastical oppression. Darwin's theory of evolution, Newton's laws of gravity and Lyell's geological findings, he held, all helped to equip men with intellectual tools to fathom the mysteries of existence without resorting to the supernatural.

In fact, throughout history, Robertson saw civilisation advancing in inverse relation to the hold over the masses of Christianity and the established church on the one hand and the spread of scientific knowledge on the other. The principle held true also for modern British society. Robertson argued that the political set-up of English society since the sixteenth century had been marked by a spirit of freedom and toleration which had from the first been predominantly anti-religious. He maintained that the great visionary reformers who had helped to shape contemporary Britain, men like, for

\footnotetext{
924 Robertson, John Mackinnon, What has Christianity Done, 1897, p.3

${ }_{925}$ Robertson, John Mackinnon, What has Christianity Done, 1897, p.6

926 Robertson, John Mackinnon, What has Christianity Done, 1897, p.3

927 Dekkers, Odin, J. M. Robertson: rationalist and literary critic, 1998, p.74
} 
instance, Robert Owen or William Morris, had all rejected established religion and freed themselves of the confines of prescribed dogma. The humanising of British laws in the early parts of the nineteenth century, he pointed out, had been carried out mainly under the influence of the freethinker Bentham ${ }^{928}$. Robertson believed that only through shedding the constrictive bonds of Christian doctrine and prescribed values had they been able to develop their novel and enlightened ideas on social justice.

In contemporary Britain, Robertson reckoned that the majority of the educated would probably consider themselves more or less unbelievers in Christianity. He also pointed to the fact that the religious establishment was losing its grip over the masses. He related that the clergy incessantly complained that the workers did not go to church. Services were empty and the clerics were increasingly forfeiting their role as confidants and authorities among the poor. "Yet", Robertson stressed his point, despite - or exactly because - of this loss of influence of established religion, '“today we are on the whole much more civilised, and certainly we are much more humane, than ever before." 929

The area of modern British society over which religious institutions still held greatest sway and which in Robertson's eyes thence needed to be addressed most urgently in the fight against the hampering impact of Christianity on social growth, was the educational sector. The retarding force in British education was not primarily creed, he specified, but sacerdotal policy. "The harm they do", he wrote referring to the churches, "is strictly in proportion to their social and political influence; and precisely as they are checked or controlled by free public opinion do we find education improve." 930

Robertson cited a study by the lawyer and Liberal politician John Gorst which showed that English schooling was very backward compared to that of for instance Scotland, the Colonies, some continental nations or the United States. Robertson believed that the comparatively better quality of public education in the above named countries could be explained by the absence of a dominant state church. The colonies and the United States could adjust their educational action easily and without the interference of a body dominated by vested interest such as the Church of England. In Scotland, the remnants of influence exercised by an established church were balanced by equally strong dissent, breaking the monopoly over education of the former. In Holland and Switzerland, too, where Catholics and Protestants formed about equal parts of the population, secular education was far ahead of schooling in England. In Switzerland, Robertson reported, the illiteracy rate had

\footnotetext{
928 Robertson, John Mackinnon, What has Christianity Done, 1897, p.7

929 Robertson, John Mackinnon, What has Christianity Done, 1897, p.7

930 Robertson, John Mackinnon, The Church and Education, 1903, p.6
} 
recently fallen below one percent ${ }^{931}$.

Robertson denied that behind ecclesiastical initiative in the field of schooling ever stood a belief in education for education's sake. The schooling provided by the churches had been self-serving. Their primary aim in educating the masses had always been indoctrination, he believed, an attempt to create a mass of faithful churchgoers firmly rooted in the church's doctrines ${ }^{932}$. Robertson reminded his readers of the Roman Catholic Church's unrelenting opposition to and repression of some of the most revolutionary scientific discoveries throughout the centuries. Rome had persecuted and excommunicated great scientists like, for instance, Galileo for fear of losing control over the ignorant masses, he argued. Even the curing of diseases by medicine, a skill immeasurably beneficial to mankind as a whole, was denounced as sinful and of the devil ${ }^{933}$.

The education offered by the Church of England Robertson described as "of the Church, by the Church and for the Church, and ill-managed at that" ${ }^{\prime 234}$. In his eyes, the charity schools which sprang up in England in the seventeenth and eighteenth century served the sole purpose not of lifting charity children from their misery and destitution, but of making them useful labourers in their inferior stations. ${ }^{935}$ With its quasi-monopoly on education, the ecclesiastical establishment had possessed an invaluable means for strengthening its own position of power and influence and for cementing the social order.

Robertson called for a comprehensive, national and compulsory state-run system of education freed of all remnants of ecclesiastical influence as the only system worthy and suited to the needs of a democratic state. Only with a curriculum established independently of vested interest could the social, political and not least the economic needs of the nation be safeguarded and national growth be ensured.

\section{Poverty and Social Fragmentation: The Double Bane of Civilisation}

But somewhat surprisingly in view of his love of science and knowledge, while others of the reformers discussed in this study placed great hopes on education as a means towards social reform,

\footnotetext{
931 Robertson, John Mackinnon, The Church and Education, 1903, p.6

932 Robertson, John Mackinnon, The Church and Education, 1903, p.9

933 Robertson, John Mackinnon, What has Christianity Done, 1897, p.6

934 Robertson, John Mackinnon, The Church and Education, 1903, p.17

935 Robertson, John Mackinnon, The Church and Education, 1903, p.21
} 
Robertson put his faith less in a national system of comprehensive schooling than in measures designed to stabilise and stimulate the economy in order to fight mass poverty.

Robertson shared Chiozza Money's belief that the first and absolutely essential precondition for cultural growth and progress in the standard of civilisation was the material comfort and security of as many members of society as possible. "A great nation's true glory", he appealed to his readers in the years leading up to World War One, "consists not in extent of soil, but in the degree of happiness and goodness [...] of the bulk of its members." $" 936$ The one great line of emulation between nations, he admonished, should not be rivalry in building hideous battle-ships, but a kindly competition in promoting the welfare of the workers whose labour made the state a reality. He argued that it was not war, the compassing of death and destruction, which ensured a nation's safety, growth and wellbeing, but the furthering of construction and life. ${ }^{937}$ The treasure wasted annually on military armaments, he held, would serve the nation's interests much better if spent on measures promoting industry and preventing poverty and destitution among its most valuable assets, its citizens.

But material comfort was only one precondition for a truly successful nation. Robertson aimed not only at an alleviation of poverty and the raising of the living standard of the entire population. He believed that mankind could immeasurably improve its chances in the evolutionary process if it learned to pool its resources and work together as a true community. Robertson therefore strove after a fundamental restructuring of society and a renewal of social relations in order to teach the citizens of the British nation to recognise their mutual dependence and their reciprocal responsibilities one towards the other.

In the area of human relations, state intervention and legislative action had obvious limitations. Robertson therefore argued that the solution of the social question required an approach from two angles. In his eyes, governmental intervention and legislative action had to be complemented by voluntary action and a rethinking within society of its values, customs and habits for social reform to achieve any lasting success. The fundamental re-formation of society and social relations economy required in Robertson's opinion a willingness on the part of the private citizen to make personal sacrifices and to reconsider his or her relations with one's neighbours. In his reformist writings, Robertson thence offered both, a list of redistributive measures such as old age pensions, national insurance systems and tax reform which needed to be implemented by the state in an attempt to ensure the material comfort of all, and on the other hand instructions for individual behaviour and personal rethinking in an attempt to strengthen the sense of community and encourage mutual solidarity within society.

936 Robertson, John Mackinnon, The Future of Liberalism, 1895, p.29
937 Robertson, John Mackinnon, The Future of Liberalism, 1895, p.30 


\section{The Uses and Limitations of State Intervention}

Robertson set out to explain at some length the uses and limitations of governmental intervention and legislative measures. In his eyes, state action was an instrument of reform which had to be applied in a selective and well-targeted manner to specific aspects of the social problem which could conceivably be solved through, or possibly even required, a certain degree of coercion.

Although Robertson considered himself a socialist, he objected to the immediate and universal transformation of all aspects of social, economic and political life through state intervention which was demanded by those whom he called the "neck-or-nothing socialists" $" 938$. Unlike, for instance, Chiozza Money who believed in the state as catalyst of instant social change, Robertson maintained that a sensible and lasting social transformation could only conceivably be brought about in a prolonged course of gradual renewal in which all members of the social community were actively involved. Strengthening the role of the state to the point of turning it not only into the dictator of laws, but also of values and opinion as Chiozza Money was prepared to do, could in Robertson's eyes never achieve an ideal society. Moreover, such power in the hands of the state could even prove harmful and disruptive. The state, in Robertson's eyes, was by its very nature too insensitive an instrument to take into account the many facets of the social and economic set-up and too powerless to change the structures and mechanisms of an economic system which was subject to laws beyond the control of any given community.

Apart from the area of human relations in which legislative coercion was downright useless, Robertson was particularly loath to allow for any form of governmental interference which threatened to upset the delicate workings of the nation's complex economic machinery. He used the proposal for an eight hours law which was widely discussed and campaigned for by the labour movement during the 1880 s and $90 \mathrm{~s}^{939}$ as an example to illustrate how legislative intervention of this kind might rock the balance of industry and prove not only useless in achieving the desired end, but inflict serious harm in seemingly unrelated areas of social and economic life.

Robertson criticised that the proponents of an eight hours law disregarded the most basic teachings of political economy and the most obvious suggestions of common sense. Long hours, he claimed, were not a matter of ill-will and exploitation, but due to pressures inherent in the industrial system. Robertson argued that the masters and capitalists found themselves in the grip of industrial currents as truly as the men. They faced depressions, seasonal fluctuations, shortages of raw materials and

\footnotetext{
938 Robertson, John M., The fallacy of saving: a study in economics, 1892, p.139

939 Robertson, John Mackinnon, The eight hours question, 1893, p.9f
} 
competition as much and with as serious a personal risk as their labourers ${ }^{940}$. The hours of work, Robertson argued, were intricately bound up with the laws of economic science and subject to questions of sound management and cost-effectiveness. They could not be modified by legislative intervention without upsetting the whole balance of industry and commerce.

In this instance, the desire to shorten the hours of work, legislative intervention was in Robertson's eyes an ineffectual instrument, useless to achieve the desired end. He refused to accept alleged precedents such as the Factory Laws of 1834 which proponents of industrial legislation cited in their favour. By contrast to, for instance, Clementina Black, Robertson fiercely denied that early nineteenth century factory legislation had succeeded in shortening the working day for women and children. "The sequelae of Factory Legislation are pointed to without any investigation of cause and effect", he criticized; "and it is assumed that because there has been improvement in the past there must be improvement in the future, given only certain restrictive legislation, no matter what the other conditions may be." 941

Robertson countered that working hours depended among other things upon the supply of hands: the greater the supply of potential labourers, the worse conditions tended to be. The Factory Laws of the early nineteenth century, he recounted, had been followed closely by a wave of emigration which had decreased the number of potential hands competing for employment. ${ }^{942}$ In Robertson's perception it was chiefly due to the consequent decrease in the supply of labour and not, as socialist propagandists made out, to legislative intervention, that a shorter working day for women and children could be carried in the wake of the factory laws. Their departure lessened the pressure on the labour market for the jobs available and thus enabled the remaining men and women to bargain for better conditions, among other things for shorter hours.

But an eight hours law would in Robertson's estimate not only fail to achieve the desired end. It would prove harmful to the delicate balance of an industrial economy in ways not anticipated by proponents of such a law. Industries which faced foreign competition, for instance, would suffer immensely from a compulsory eight hours law, Robertson pointed out. Forced to pay dearly for extra labour, prices for output would necessarily rise and render trades like, for instance, the British chemical industries or clothes manufacturing, unprofitable ${ }^{943}$. On the other hand, however, it was premature to hope that this increase in the costs of production could be used to eliminate specific undesirable trades such as the sweated industries by making them unprofitable. It was true, Robertson conceded, that a shortening of hours would affect output in the low skill trades, making it

\footnotetext{
940 Robertson, John Mackinnon, The eight hours question, 1893, p.4

${ }_{941}$ Robertson, John Mackinnon, The eight hours question, 1893, p.16

942 Robertson, John Mackinnon, The eight hours question, 1893, p.58f

943 Robertson, John Mackinnon, The eight hours question, 1893, p.73
} 
necessary for masters to employ additional labour at considerable extra cost. But even if the underpaid and overworked trades were forced out of business, in consequence of their demise an immense number of hands would be thrown idle. Robertson pointed out that such hands would then seek employment in other trades, increasing the pressure of labour on the available jobs, forcing down wages and worsening conditions ${ }^{944}$.

Robertson thus warned that governmental intervention must not aim at meddling with the processes of industry which ran according to their own inherent laws. Like Percy Alden, Robertson believed that a state could only ever hope to cure the ill-effects of industrial processes, not to prevent or treat them directly by cutting at their roots. Robertson therefore limited his advocacy of state interference to measures designed to balance out the harmful side-effects of an industrialised economy. His focus thereby lay on redistributive provisions which affected the workings of industry and commerce only indirectly by alleviating poverty and maintaining the purchasing powers of the poorer sections of society even in times of distress. Foremost among those in Robertson's mind were the establishment of national systems of insurance against unemployment and sickness and the introduction of old age pensions.

a) The Fallacy of Saving and the Need for a National Insurance System

One of the ways in which state intervention could, in Robertson's eyes, make an impact and contribute to social improvement was through the establishment of a national system of insurance against life's contingencies such as unemployment, sickness, accidents and old age. He believed that providing the workers with a certain degree of security against such instances of sudden need would induce the confidence among the masses needed to encourage spending and stimulate the economy. Like Alden, Black and Money, Robertson rejected the customary recommendation for providing for old age, unemployment and sickness: the belief in thrift and saving propagated by orthodox economists and traditionally-minded social reformers. In Robertson's eyes, encouraging the majority of the population to practice thrift constituted a grave economic mistake. He rejected the traditional view of political economy that parsimony and thrift conduced to the well-being not only of him who practised it, but of the whole social body in an industrialised nation ${ }^{945}$. Part of the problem lay in the nature of saving and "savings" as such. Old school political economists described such saved-up money credit wrongly as "capital". The very idea of capital in that sense

\footnotetext{
944 Robertson, John Mackinnon, The eight hours question, 1893, p.91

945 Robertson, John Mackinnon, The fallacy of saving: a study in economics, 1892, p. 12
} 
was illusory, Robertson countered. The saving of money from income and the accumulation of credits, he argued, could only ever constitute a saving of "claim to wealth"; such claim was not at all represented by any actual wealth, a fact easily recognised if one attempted to exchange the whole mass of money capital or bankers' credits for actual property. Such an undertaking would so immensely raise prices as to prove clearly the very abstract nature of "saved" capital.

To recommend saving as a means of providing for old age may, Robertson conceded, prove a successful policy in individual cases as it had done for much of the middle classes in the past decades $^{946}$. As a large scale plan against pauperism among the aged, however, it was simply absurd. Robertson ridiculed the idea that everybody might accumulate claim over the services of everybody else, and so secure all round the advantages that were enjoyed by the few who at present accumulated claim over the services of the many. ${ }^{947}$ The very universality of such provisions would reduce the purchasing power of private savings to insignificance and leave the problem of old age pauperism virtually untouched. "The economic truth is accurately put by Ruskin in the formula that riches are a power like that of electricity, acting only through inequalities or negations of itself' ${ }^{\prime 948}$, he quoted. The value of a guinea in one's pocket entirely depended upon the default of a guinea in one's neighbour's purse.

Moreover, he pointed out that saving as a panacea for old age pauperism was not only illusory. Robertson believed that to withhold money from circulation on a large scale was positively harmful to the community at large. In his book The Fallacy of Saving he developed an argument of underconsumption which chimed in perfectly with the more renown theory of John Hobson and Albert Mummery in their classic The Physiology of Industry (1889) of which we have heard in the first chapter of this study. The interests of a healthy economy, Robertson asserted, were better served by the regular flow of actual, tangible money which could be exchanged for actual and tangible goods and services than by the amassing of theoretical claim to wealth which was by its very nature fleeting and to some degree imaginary ${ }^{949}$.

Robertson traced the notion of saving as beneficial to an industrialised society as a whole back to Adam Smith's classic text book of political economy, The Wealth of Nations ${ }^{950}$. Smith's personal experience had taught the thinker that money accumulated in the hands of bankers did - under certain circumstances - stimulate industrial growth. But the theory held good only for societies in the early stages of industrialisation, Robertson believed. Smith's argument depended upon the distinction between productive employment in industrial enterprises which was beneficial to the

\footnotetext{
946 Robertson, John Mackinnon, The fallacy of saving: a study in economics, 1892, p.120

947 Robertson, John Mackinnon, The fallacy of saving: a study in economics, 1892, p. 10

948 Robertson, John Mackinnon, The fallacy of saving: a study in economics, 1892, p.93

949 Robertson, John Mackinnon, The fallacy of saving: a study in economics, 1892, p.7

950 Smith, Adam, An Inquiry into the Nature and Causes of the Wealth of Nations: in Two Volumes, 1776
} 
wealth and well-being of a community and unproductive employment, for instance in domestic service or the luxury trades, a distinction we have already encountered in the previous chapter on Chiozza Money. Money saved, and hence not spent on servants or entertainment, Smith argued, constituted resources available for the instigation of new industrial undertakings, and thus of useful, productive employment ${ }^{951}$.

Unlike Chiozza Money who based his argument for nationalisation on the idea that wasteful employment existed and must in a healthy industrial economy be minimised, however, Robertson believed that in a fully industrialised society like end-of-century Britain the distinction between useful and wasteful labour could no longer be maintained. In a society where the supply of industrially manufactured goods was largely sufficient, it was no longer necessarily profitable for employers to extend production or to initiate new undertakings ${ }^{952}$. Also, with the introduction of new machinery, the need for specialisation had increased in industrial production; labourers unskilled in the required tasks could no longer easily be transferred from, for instance, employment as gamekeepers to a job in a factory. Lastly, in end-of-the-century Britain the supply of labour hugely outran demand in the industrial sphere. Under such conditions, any form of employment, whether it fell into the category of what Smith called productive or unproductive, had to be considered conducive to national wealth and welfare.

Industry, Robertson pointed out, was a matter of supplying markets, and the employing class always spoke of the necessity of finding new markets. The nation had even entered upon wars to find them. "And yet", Robertson marvelled, "not only the 'orthodox economists', but this very employing class habitually reason on the assumption that industry depends for its maintenance on abstinence from consumption, that is, the restriction of the market demand for goods." ${ }^{953}$ Smith had argued that if the rich and idle abstain from certain forms of consumption, the money saved would put new members of the community into a position to consume goods and services conducive to industrial health. But the mechanism of balancing out of consumption certainly collapsed, Robertson argued, when labourers, too, the very members meant to be empowered to consume, were then expected to save, or in other words, to abstain from consumption. It was illogical, he pointed out, to expect simultaneously a rise in consumption through new employment and to advocate saving for all..$^{954}$ Industrial growth could obviously only continue when the things produced were bought. In the terms of Smith's doctrine, if applied universally, there ought to be no one to buy them. Thus, in Robertson's thinking, classical political economists propagated as a panacea a principle which

\footnotetext{
951 Robertson, John Mackinnon, The fallacy of saving: a study in economics, 1892, p.14

952 Robertson, John Mackinnon, The fallacy of saving: a study in economics, 1892, p. 16

953 Robertson, John Mackinnon, The fallacy of saving: a study in economics, 1892, p.9

954 Robertson, John Mackinnon, The fallacy of saving: a study in economics, 1892, p.16
} 
verifiably harmed industry by docking consumption.

Robertson postulated that an ideal of consumption be substituted for an ideal of parsimony in order to stimulate "industrial confidence" and boost the creation of national wealth ${ }^{955}$. In a fully industrialised nation, demand for products rather than supply of readily available capital regulated industry and commerce, he held. Consumption was thus of the very essence for economic progress. Robertson provoked contemporaries with the argument that the pauper class, insofar as its members were industrious, but unthrifty workers, had all along done more for the nation's economic health and prosperity than the better-off savers. ${ }^{956}$

But spending, as much as the traditionally recommended habit of saving, was made difficult or even impossible among the poor by irregularity of income, unemployment or casual work, sickness or simply by low pay and long hours ${ }^{957}$. It was therefore imperative in the interest of industrial growth as well as social health, Robertson reasoned, that the consuming power of the most easily depressed sections of the population be extended and maintained. Robertson argued for old age pensions and national insurance against unemployment and invalidity as the most effective means of sustaining the purchasing power of the poor ${ }^{958}$. "[I]t will be the principle service a pension scheme can render, to encourage the workers to consume and not paralyse production by restricting their demand"959, Robertson envisaged.

Besides the economic argument, Robertson also offered a philosophical justification for old age pensions and insurance against unemployment or sickness which reflected his understanding of society as a contractual community. In his eyes, society had a clear duty to provide for all its members. ${ }^{960}$ The basis of said duty was for Robertson the "law of reciprocity" 961 of service. What ultimately maintained a state, as a political as well as as a social whole, was the sum of activities of its members, he suggested. Foremost among those was activity which resulted in the production of goods, material as well as intellectual ${ }^{962}$. In Robertson's eyes, whosoever contributed to the wealth and welfare of the nation, by way of producing its necessaries, furthering its cultural heritage or governing it, was entitled to a return of such service when in need, in other words, to maintenance in old age, invalidity or times of unemployment. The community already accepted and acted upon the idea of state pensions in the cases of civil servants, the military, municipal employees. Why, Robertson asked, should the principle not hold good on a universal scale?

\footnotetext{
955 Robertson, John Mackinnon, The fallacy of saving: a study in economics, 1892, p.90

956 Robertson, John Mackinnon, The fallacy of saving: a study in economics, 1892, p.132

957 Robertson, John Mackinnon, The Future of Liberalism, 1895, p.20

958 Robertson, John Mackinnon, The Meaning of Liberalism, 1912, p.63

959 Robertson, John Mackinnon, The fallacy of saving: a study in economics, 1892, p. 129

${ }_{960}$ Robertson, John Mackinnon, The Meaning of Liberalism, 1912, p.43

961 Robertson, John Mackinnon, The Meaning of Liberalism, 1912, p.47

962 Robertson, John Mackinnon, The Meaning of Liberalism, 1912, p.69
} 
"A State subsists by its industries of all kinds at least as much as by its military and civil service", he pointed out, and every single citizen was as much indebted to the maker of his or her clothes, the producer of food and the builder of houses as to the postman or the tax collector ${ }^{963}$. Robertson considered it a disgrace to civilisation that law-abiding, service-rendering, state-supporting citizens should end their lives in utter penury while the idle rich lived to the end of their days in comfort and luxury ${ }^{964}$. He postulated that "those of the proletariat who had reached old age without contriving an adequate provision for their own maintenance were to be treated rather as worn-out servants of the community than as wrecks and wastrels entitled to mere charity" ${ }^{\prime 965}$. In the case of old age pensions and national insurance, he observed, humanity and economic science joined hands ${ }^{966}$.

\section{b) The Axioms of Just Taxation}

The second measure to be implemented by the government which Robertson advertised was a redistribution of the nation's wealth through changes in the system of taxation. Robertson argued for a reform of the rates and levies, central as well as local, to disperse the burden of the community's upkeep more fairly and to shift a greater part of the encumbrance onto the shoulders of the wealthy. Not least he hoped to be able to pay for the establishment of national systems of insurance and the introduction of old age pension through the additional revenue raised by an improved tax system.

Taxation, Robertson cautioned his fellow-reformers, constituted an ethically complicated matter. Robertson detected a dilemma in the collection of rates and levies: the machine of state could not be run without adequate funds, Robertson pointed out, and the more organised a state became, the more pressing grew the fiscal problem ${ }^{967}$. But Robertson stressed that in discussing the matter, one had to address the fact that taxation amounted to a seizing of another's private property. In order to justify taxation and make the collection of rates and taxes from individuals for use by the state legitimate, it therefore had to rest on a sound philosophical as well as practical basis. Robertson dealt with the problem of fiscal justice at length in The Great Budget, an exposition of the Liberal budget of 1909. In it, he argued that justice, not profitability, had to be the guiding principle of the legislator and the tax collector. "It is the bounden duty of every government", Robertson postulated, "to impose the most just form of taxation in preference to others, where they are both practicable

\footnotetext{
963 Robertson, John Mackinnon, The Future of Liberalism, 1895, p.20

964 Robertson, John Mackinnon, The Meaning of Liberalism, 1912, p.64

${ }_{965}$ Robertson, John Mackinnon, The Meaning of Liberalism, 1912, p.61

966 Robertson, John Mackinnon, The Meaning of Liberalism, 1912, p.63

967 Robertson, John Mackinnon, The Meaning of Liberalism, 1912, p.53
} 
and profitable." $" 968$

Like Leo Chiozza Money, Robertson rested his deliberations on a just system of taxation on the Smith-Millean formula of "equality of sacrifice" 969 . It was a principle which demanded a careful balancing of a person's means and needs, but also of his or her role in society and contributions to communal life. Robertson explained that a just system of taxation was more than the indiscriminate collection of a certain percentage of a person's property or income in the interests of the common good. One aspect to be taken into consideration was the relative wealth or poverty of the taxed: a tax which a rich man hardly felt, for instance, might represent a serious sacrifice to the poor.

It was the very reason why in his eyes food taxes and indirect taxes on necessaries of all kinds should immediately be abolished. The poorer a family, the larger a part of its resources it spent on food and basics ${ }^{970}$. "Taking all of those taxes into account, we find that the share of an average workman's wage absorbed by the state is relatively much larger than the share taken from the rich by those taxes and Income Tax together" ${ }^{\prime \prime 71}$, he observed. As long as food articles were taxed, those at or below the poverty line were taxed on their bare subsistence. The outcome of such indiscriminate taxes was that the state actively curtailed the life and strength of a number of its members, Robertson pointed out ${ }^{972}$. The practice constituted national folly as well as social injustice. If the necessary revenue could be raised without such curtailment of life opportunities, Robertson demanded, it was the plainest duty of any government to arrange its taxation accordingly ${ }^{973}$.

Robertson maintained that direct taxes such as income taxes or property taxes were on the whole much more equitable than indirect taxation on food and necessaries. But Robertson stressed that also in the cases of income and property taxes in any form the government must refrain from an indiscriminate imposition of rates and consider carefully the social and economic consequences as well as all aspects of feasibility and justice before introducing a new kind. Thus, for instance, in the case of income taxes, Robertson saw a marked difference in justifiability and social consequences between taxes on earned versus unearned income. In a vein similar to Chiozza Money, he used the cases of a doctor and a landowner who both had to pay taxes on the same income as an example to illustrate his argument. The doctor, Robertson explained, paid out of an income that he had worked for. He made a sacrifice in terms of labour: to pay so much tax, he had to do a certain number of

\footnotetext{
968 Robertson, John Mackinnon, The Great Budget, 1910, p.15

969 Robertson, John Mackinnon, The Great Budget, 1910, p.4; see also Robertson, John Mackinnon, The Meaning of Liberalism, 1912, p.67

970 Robertson, John Mackinnon, The Meaning of Liberalism, 1912, p.66; see also Robertson, John Mackinnon, The Great Budget, 1910, p.5

971 Robertson, John Mackinnon, The Meaning of Liberalism, 1912, p.66

972 Robertson, John Mackinnon, The Great Budget, 1910, p.44

973 Robertson, John Mackinnon, The Great Budget, 1910, p.15f
} 
days of work. The landlord, Robertson insisted, who paid out of unearned income, made no sacrifice in respect of labour whatsoever. ${ }^{974}$ While the doctor paid twice, in terms of services which contributed to the common good as well as in terms of money, the landlord benefited the community only through the rates levied upon his property. Since he rendered no other useful service to society, Robertson considered it fair that the landowner should be taxed at higher rates ${ }^{975}$.

The 1909 People's Budget of the Liberal government which Robertson set out to explain in his book The Great Budget, had in his opinion for the above reasons justly singled out unearned increment from land values for special taxation to pay for long-needed social reforms. "The land values which the new principle aims at taxing, are the most typically unearned forms of wealth, apart, that is, from inheritance", Robertson explained; "and it is primarily because they are unearned that they are taxed." ${ }^{976}$ By contrast, shareholders in railway companies, banks, industrial or commercial concerns in Robertson's eyes acted as captains of industry, taking part in social undertakings. Shareholders lent their money to the public, at considerable risk to themselves, in order that it might help to increase national wealth. They must therefore be treated differently from landowners, he asserted.

Land, Robertson further elaborated, was uniquely essential to communal life. "Who says community says land", he maintained; "and the fiscal and other control of the land is an essential preliminary to the effectual control by the community of its own destinies."977 Like Stewart Headlam, Robertson doubted the legitimacy of the present system of private ownership in land. Like Headlam, he traced it back to the feudal period where property in land had been tied to certain duties towards the community. All land was then held under the crown for the public good, no man being allowed to have a right to it without rendering some public service in return. The idea of service as attached to ownership in land had been sadly neglected in recent centuries, but in Robertson's as in Headlam's eyes, still held good. The old responsibilities, both argued, should be rightfully transmuted into a duty to pay taxes ${ }^{978}$. Also, the unique significance of land for communal life demanded of the legislature to adjust its fiscal system in such a way as to put some restraint in the public interest on the exploitation of the entire community by the land monopolists; especially when such restraint constituted the most just form of taxation conceivable ${ }^{979}$.

Like Headlam and Percy Alden, Robertson considered land value to be a value created by the community. Property in land was already subject to local rates. Robertson saw no reason why the

\footnotetext{
974 Robertson, John Mackinnon, The Great Budget, 1910, p.10

975 See also, Robertson, John Mackinnon, The Great Budget, 1910, p.18

976 Robertson, John Mackinnon, The Great Budget, 1910, p.11

977 Robertson, John Mackinnon, The Great Budget, 1910, p.26

978 Robertson, John Mackinnon, The Great Budget, 1910, p.25

979 Robertson, John Mackinnon, The Great Budget, 1910, p.27
} 
same principle of taxability could not apply on a national level. "The increment in given land values (...) is a result not solely of the existence and activity of the inhabitants of the parish, town, or locality in which the land is situated" ${ }^{980}$, he claimed. It was a result of the total industrial and social activity of the nation and was even in many cases directly traceable to particular national expenditure or policy, as in the case of dockyard towns. Nothing, he stated, could be plainer than the total gratuitousness of most of the private gain from increment in land values. Much of it arose from social phenomena such as urbanisation, from an expansion of industry or from public improvements such as road building, tramway lines or slum improvements ${ }^{981}$. Robertson considered it rightful and just for the state to tax land values arising from communal activity for national as well as local purposes. In the case of land, he saw the fullest moral justification for the tax as well as the fullest practical justification in respect of the financial, social, and industrial results arising from its imposition. ${ }^{982}$

\section{The Limits of State Intervention and the Need for Voluntary Action}

But in all his writings Robertson stressed that notwithstanding the positive effects governmental action could have through measures such as tax reform and insurance systems, state interference and legal intervention could only assist the process of communal growth and could at best repair the most blatant evils of industrial society. Above all else, Robertson believed, a reform of society required individual initiative and personal dedication to the national cause. In a first step, he postulated, the citizens of Great Britain had to learn to take responsibility for themselves and their own lives if the nation was to prosper and civilisation to expand. ${ }^{983}$ "Let short-sighted Socialists deny it a hundred times over", he wrote, "it remains unalterably true that the one security for human elevation is the consciousness of self-rule, self-reliance, and self-determination." 984 In a second, and possibly even more important step, the individual then had in Robertson's opinion to recognise that he or she was a member of a social community, a body of people who depended one upon the other and who were tied to each other through moral bonds and mutual responsibilities.

\footnotetext{
980 Robertson, John Mackinnon, The Great Budget, 1910, p.14

981 Robertson, John Mackinnon, The Great Budget, 1910, p.22f

982 Robertson, John Mackinnon, The Great Budget, 1910, p.15

983 Robertson, John Mackinnon, The eight hours question, 1893, p.121

984 Robertson, John Mackinnon, The eight hours question, 1893, p.120f
} 
In this sphere of morality and human interdependence, Robertson argued, legislative intervention and state interference showed serious limitations. "Inasmuch as political action takes the form of law, compulsory on all, it cannot give such scope to the principle of self-sacrifice as the "law of love" may dictate to the individual in his private action" $" 985$, he observed. One man may freely give his blood to be transfused into the veins of another, the law could never demand him to do so. Parents may make heavy sacrifices for their children - the law could only ever aim at "equality of sacrifice and reciprocity of service" ${ }^{986}$. National growth and communal welfare, Robertson impressed upon his readers, depended heavily upon a realisation that the present set-up of society was morally wrong and that the interests of the community demanded personal involvement and sacrifice from every single member of the community.

Robertson thus complemented his catalogue of state-run measures with instructions to the individual citizen on how to assist the cause of social reform through changes in everyday behaviour and through modifications in one's attitude towards one's neighbours.

a) Raising the Standard of Consumption

Some of the measures which Robertson recommended to his fellow-citizens were comparatively straight-forward rules of conduct. Thus, he advocated a change in the habits of purchasing and consumption among all sections of society in order raise the standard of consumption and help to stabilise and assist the growth of the nation's economy.

Robertson saw that maintaining the purchasing power of the most easily depressed sections of society, as he hoped to achieve through a national system of insurance against unemployment and sickness and the introduction of old age pensions, would not in itself suffice to boost the economy. Healthy trade depended upon expanding markets he knew; and as quantity of consumption could not be increased indefinitely, Robertson doted on a raised quality of consumption to ensure economic growth ${ }^{987}$ as the second of his recommendations in the fight against poverty.

All classes of society, he believed, had to be encouraged to switch from cheaply and easily produced consumables to goods and services not mechanically facile of production. Already there existed branches of trade notoriously prone to overproduction, a state which tended to produce as much unemployment as did underproduction. Especially industries which produced cheap goods for working class consumption were in perpetual danger of outrunning demand. Other trades ran the

\footnotetext{
985 Robertson, John Mackinnon, The Meaning of Liberalism, 1912, p.47

986 Robertson, John Mackinnon, The Meaning of Liberalism, 1912, p.48

987 Robertson, John Mackinnon, The fallacy of saving: a study in economics, 1892, p.90
} 
risk of overproduction when new inventions such as new machinery or less labour-intensive modes of production, facilitated and speeded up the production of previously expensive goods.

Only by setting labour previously employed in the manufacture of such goods to more skilled and artistic employment, Robertson believed, could overproduction be perpetually avoided ${ }^{988}$. "It is not quantity, but kind of consumption, the setting up a continuous demand which shall withdraw labour from the fatally easy fruitions of the mechanical manufacture of common necessaries, that will prevent chronic depression of trade" ${ }^{989}$, he wrote. Raising one's standard of consumption required, of course, the private initiative of every single member of the community. A "universal diffusion of luxury" ${ }^{990}$ which for Robertson started with basic supplies such as good furniture and ornamented household goods would at the same time ensure employment and steadiness of trade as well as raise the general standard of culture and civilisation among the entire nation.

b) The Need for Population Control

An ever-rising standard of demand, however, Robertson cautioned, was impossible without "such a restraint of the rate of increase of population as shall give scope for the play of higher and subtler needs without fatal encroachment on the part of the simpler and lower"991. The second recommendation which Robertson gave his fellow-citizens to fight mass poverty was thus put an end to the squeamish attitude of British society to matters of family planning and population control and to exercise "procreational prudence" 992.

Robertson carefully stressed that the higher stage of human as compared to animal evolution, the struggle for civilisation rather than survival, did not abrogate the basic laws of nature. Robertson feared the disastrous consequences of overpopulation as envisaged by the economist and demographic theorist Thomas Robert Malthus ${ }^{993}$ towards the end of the eighteenth century. Malthus had formulated a law of population which argued that "population tend[ed] to increase faster than the means of subsistence" $" 994$ which remained highly influential among British intellectuals even almost a century later. Malthus' pessimistic view of human society claimed that any progress in social conditions would result in a growth of population up to a point which would nullify the

\footnotetext{
988 Robertson, John Mackinnon, The eight hours question, 1893, p.67

989 Robertson, John Mackinnon, The fallacy of saving: a study in economics, 1892, p.113/4

990 Robertson, John Mackinnon, The eight hours question, 1893, p.147

991 Robertson, John Mackinnon, The fallacy of saving: a study in economics, 1892, p.114

992 Robertson, John Mackinnon, The fallacy of saving: a study in economics, 1892, p. 128

993 Thomas Robert Malthus (13 February 1766 - 23 December 1834),was an Anglican cleric andeconomist whose main legacy were his theories on the cyclical development of population.

994 Robertson, John Mackinnon, Overpopulation. A Lecture, 1890, p.4
} 
progress achieved. The increase in population would according to Malthus eventually be checked by famine or disease, and the cycle of progress and destruction start anew.

Robertson believed that none of the contemporary arguments against Malthusianism had succeeded in disproving the theorist's law of population. In his eyes, the essence of the law remained untouched even though industrialisation and progress in the natural sciences had made possible a much increased production of wealth; nor was the cycle of population growth and destruction negated by the discovery of new uninhabited territory which provided new living space and additional resources for surplus population, or by the immense capacity of growing wheat exhibited lately by the USA ${ }^{995}$.

Malthus had not denied the possibility of a net increase of population, Robertson pointed out; but even at a time of absolute growth, surplus population among men tended to die off just as did surplus populations in the animal kingdom ${ }^{996}$. Codfish, he argued in a vein similar to Money, produced two million eggs per season, only a fraction of which actually developed into adult fish. "[A] viable species, a species which maintains itself in a state of nature", he stated, "is one that propagates greatly in excess of the possibilities of continued life." ${ }^{997}$ Among humans, too, hundreds of thousands of children had died or would still die in the destitute neighbourhoods of industrial towns from sheer want of proper sustenance and healthy surroundings. Yet, their very disappearance seemed to blind many people to the reality of the development: Robertson observed bitterly that while they died unobserved in the darkness of the slums and the wilderness of huddled houses, the philanthropist and the politician could pretend that there was no problem of over-population among humans ${ }^{998}$.

And yet, in Robertson's eyes, the problem of population was of the essence in all matters of social reform. "[W]hile you effect your reform", he pressed his point, "you must also begin to secure a better control of the instinct which brings about reproduction of the species, because without that reform all other reforms will in the long run be futile." 999 Left to its own devices, the human population tended to be held in check by famine, disease and war. Such destructive checks, however, worked relatively to the degree of civilisation in a given community, and the recent awakening of sympathy in society towards the misery of the poor and the increasing volume of philanthropy and state provisions had begun to counterbalance even the few remaining "natural" checks $^{1000}$.

\footnotetext{
995 Robertson, John Mackinnon, The eight hours question, 1893, p.123

996 Robertson, John Mackinnon, Overpopulation. A Lecture, 1890, p.6

997 Robertson, John Mackinnon, Overpopulation. A Lecture, 1890, p.6

998 Robertson, John Mackinnon, The eight hours question, 1893, p.131

999 Robertson, John Mackinnon, Overpopulation. A Lecture, 1890, p.10

${ }^{1000}$ Robertson, John Mackinnon, Overpopulation. A Lecture, 1890, p.18
} 
In the absence of destructive checks, the superfluous births all too often developed into adults, putting pressure on the limited means of subsistence, degrading the nation as a whole. "Observe", he wrote, "there is a long range of possibilities between comfort and starvation"1001. At present, not only did many die of misery in their childhood or early adulthood, but many more children and adults lived on in misery, physically and mentally maimed through lack of food and space. School meals, charity hospitals, slum improvements, state schools and holiday funds all worked as powerful stimulants to procreation; if unaccompanied by "rational teaching as regards future parentage", Robertson feared, they all amounted to pouring oil on the fire. ${ }^{1002}$ Nothing short of procreational prudence could ultimately save the proletariat from hardship and ensure the physical and moral progress of the nation.

Robertson postulated the introduction of preventive checks to replace the natural destructive checks. If surplus births were no longer killed off by famine and disease, such births had to be prevented in the first place to safeguard the health of the species. In Robertson's eyes, the law of population constituted a natural, not a social or moral law. The public outrage at suggestions for birth control as propagated by neo-Malthusianism was thus, in his opinion, totally misplaced. Here, too, Robertson detected the corrupting and impeding influence of religious establishments which made men believe that birth control was sinful and in essence amounted to murder. He fiercely attacked the bigot attitude of late-Victorians on the issue: "We are so zealous that all germs of life shall be cultivated in order to be indirectly killed and formally buried", he wrote. "We insist that every possible child shall be born; after that, let the devil take the hindermost." ${ }^{1003}$ The means of checking population without crime, vice and misery were known and had been tested; and yet, a large section of the respectable public pretended not to know about them, was shocked when they were alluded to or contrived to put in jail everybody concerned, Robertson wrote ${ }^{1004}$.

Education and the raising of living standards as, for instance, the churches suggested, could not in Robertson's opinion suffice to solve the problem. True, he conceded, the middle and upper classes tended to have fewer children than the poor. But education was too slow a process to be of

${ }^{1001}$ Robertson, John Mackinnon, Overpopulation. A Lecture, 1890, p.5

${ }^{1002}$ Robertson, John Mackinnon, Overpopulation. A Lecture, 1890, p.18; see also Robertson, John Mackinnon, The fallacy of saving: a study in economics, 1892, p. 135

${ }^{1003}$ Robertson, John Mackinnon, Overpopulation. A Lecture, 1890, p. 15

${ }^{1004}$ The most famous case of imprisonment for propagation of birth control at the time of Robertson's writing was without doubt that of Charles Bradlaugh and Annie Besant. In 1877, Bradlaugh and Besant were tried for republishing a pamphlet on birth control by the American Charles Knowlton entitled The Fruits of Philosophy or the Private Companion of Young Married Persons. See Knowlton, Charles et al., Fruits of Philosophy. An essay on the population question... New edition, with notes [by G. R., i.e. George Drysdale, and a preface by Charles Bradlaugh and Annie Besant], 1877. Bradlaugh and Besant were sentenced to heavy fines and six months imprisonment for "obscene libel", but the verdict was overturned in 1878 on a technicality. In court, Besant and Bradlaugh defended themselves with the same arguments enlisted by Robertson, stating that they preferred children to remain unborn rather than to murder them by want of food, air and proper clothing. The trial was widely publicised. 
immediate use. No theory of refinement, Robertson pointed out, could work as long as nine-tenth of the population were unrefined ${ }^{1005}$. He called to his contemporaries to recognise how much misery neo-Malthusianism (as the propagation of birth control was dubbed) had already alleviated. "But for its propaganda", he believed, "the industrial situation in this country at this moment would be much worse than it really is." ${ }^{1006}$ During the years 1886 and 1890, he detected a marked decline in the number of births, along with an increase in the number of marriages. While there were 27.222 more marriages in 1890 in England and Wales than in 1886, there were 33.279 fewer births. While some of the effect was certainly due to the epidemic of influenza in the year 1890, Robertson believed that the spread of neo-Malthusian propaganda had contributed decisively to the decline ${ }^{1007}$.

c) Building up a Spirit of Community

Other tasks to which Robertson wanted to commit his contemporaries were of a more general, less defined nature. They concerned relations with one's fellow-citizen and the recognition of mutual dependence and reciprocal responsibilities.

Robertson believed that society could flourish only if it learned to think of itself in terms of a community. He heavily criticised those sections of the labour movement which flourished on class antagonism and were geared towards class politics ${ }^{1008}$. Like Stewart Headlam, Henrietta Barnett and Percy Alden, Robertson felt ambiguous about the newly forming Labour Party. He welcomed the realisation that English politics had been determined by the vested interests of the upper classes for centuries and urgently needed to be reformed in the interests of justice. But reformers too often acted as if "labour" implied a double share of original righteousness and common sense.

Thinking along lines similar to Headlam's reasoning, Robertson pointed out that the working man was no more immune to class blindness than was the rich. As the rich often failed to see that he was but a man with wealth added, the poor tended to disregard the fact that he was but another without wealth, with the same passions, illusions and endless fallibilities as all other human beings. Being a labourer afforded no superior qualifications in politics. "The need to earn his bread by the sweat of his brow gives no man any special insight into the larger problem of social science" ${ }^{1009}$, Robertson remarked. The motive of simple class sympathy could not of itself conduct men to political wisdom. On the contrary, many socialists were so caught up in their campaigning for working class interests

\footnotetext{
${ }^{1005}$ Robertson, John Mackinnon, Overpopulation. A Lecture, 1890, p.12

${ }^{1006}$ Robertson, John Mackinnon, The eight hours question, 1893, p.128

${ }^{1007}$ Robertson, John Mackinnon, The eight hours question, 1893, p.130

${ }^{1008}$ Robertson, John Mackinnon, The Meaning of Liberalism, 1912, p.141

${ }^{1009}$ Robertson, John Mackinnon, The Meaning of Liberalism, 1912, p.226
} 
that they lost sight of the common good and the well-being of the entire community. Science, rational and logical thinking played no part in revolutionary, the erroneously so-called "scientific", socialism $^{1010}$.

For Robertson, socialism had predominantly moral connotations; its merits lay not in the economic, but in the ethical and interpersonal spheres. He hoped that the vision of a perfect social community as transported by socialism would mobilise and motivate the men and women of Great Britain to work towards more just and equitable conditions. An ideal state presupposed a minimum quota of decently ideal people ${ }^{1011}$, Robertson conceded. At present, human nature, driven by antagonistic feelings like competitiveness and selfishness, was not yet capable of the perfect sense of brotherhood necessary for a harmonious socialist society ${ }^{1012}$ "The amount of co-operative faculty faculty as distinguished from mere aspiration - required to conduct a wholly socialised society is enormously greater than anything yet evolved in any society whatever" ${ }^{\prime 1013}$, Robertson pointed out. But the social body was a living structure subject to change; it could modify itself by will even if the process could not be an instant transformation, but demanded a thousand successive adjustments ${ }^{1014}$. In order to become capable of all-round cooperation as demanded by the idea of socialism, it had to undergo a whole series of experiences in widening cooperation. To replace the fundamental instinct of competition by one of cooperation involved a complete re-adjustment of almost all social functions ${ }^{1015}$, Robertson explained. The vision of a social utopia as conjured up by socialism was in Robertson's eyes a useful guide for men on their possibly tedious way towards social perfection.

Instead of preaching class war and social hatred, socialists would do immensely better to call for "love, sympathy, patience and mutual comprehension""1016, Robertson offered. He rejected a moral hierarchy of classes as set up by Marxist ideology which consigned "whole millions of human beings to odium or promote[d] them to honour on the strength of the mere social classification in itself' ${ }^{\prime 017}$. Ascribing set characteristics and exclusive habits to specific classes was in Robertson's eyes too simplistic. Marxists called for the destruction of a system of rent drawing which, they held, enabled the rich to live idly. But Robertson showed that millions of working class members, too, benefited from rent drawing through membership in friendly societies, private insurance initiatives and cooperatives: the whole system of self-help involved at every stage the process of interest-

\footnotetext{
${ }^{1010}$ Robertson, John Mackinnon, The Meaning of Liberalism, 1912, p.141f

${ }^{1011}$ Robertson, John Mackinnon, The Meaning of Liberalism, 1912, p.182

${ }^{1012}$ Robertson, John Mackinnon, The Meaning of Liberalism, 1912, p. 153

${ }^{1013}$ Robertson, John Mackinnon, The Meaning of Liberalism, 1912, p. 179

${ }^{1014}$ Robertson, John Mackinnon, The Meaning of Liberalism, 1912, p.241

${ }^{1015}$ Robertson, John Mackinnon, The Meaning of Liberalism, 1912, p. 240

${ }^{1016}$ Robertson, John Mackinnon, The Meaning of Liberalism, 1912, p. 180

${ }^{1017}$ Robertson, John Mackinnon, The Meaning of Liberalism, 1912, p.151
} 
drawing. Also, far from necessarily being idlers, many of the rich rendered invaluable service to the community as captains of industry, inventors of machinery, artists or intellectuals, Robertson pointed out. Managers and organisers would under any social and economic set-up of the near future continue to play their part as the brain-workers of the industrial system, albeit hopefully under a series of modifying conditions such as redistributive taxation and social legislation ${ }^{1018}$.

At present, Robertson detected two fundamentally conflicting war cries in English politics. While socialists proclaimed that "all wealth [was] the product of labour", conservatives countered that "all labour [was] maintained by capital" ${ }^{1019}$. Robertson believed neither to be entirely correct; both told only part of the truth. Labour and capital, he pleaded instead, had to finally recognise their mutual dependence one upon the other. Industry and commerce required both, heads as well as hands, and it was essential that both parties work together for the health and progress of the entire nation. Robertson likened the captains of industry and their army of workers to Julius Caesar and his legions. Without Caesar, there would have been no legions, but "merely a helpless series of scattered units, at best capable of extorting a scanty livelihood from an ill-guarded soil" ${ }^{1020}$. The army of workers in turn-of-the-century Britain could not by themselves successfully run a functioning economy, Robertson implied. But Caesar, too, depended upon his soldiers for his own greatness and had responsibilities towards them. Modern capitalists and employers tended to be less enlightened than the leaders of swordsmen in antiquity. "It is because most of the modern captains of industry have never contrived to give their veterans either steady subsistence during their fighting years or security for old age", Robertson stated, "that their legions are in large measure distrustful, semi-hostile, disparaging towards their captains." 1021

Robertson was not surprise to see them bent on evoking a system of state which would provide for the masses of workers at the cost of their social superiors. If the problem of modern civilisation was to be solved, Robertson pleaded, both workers as well as capitalists needed to muster up greater patience and magnanimity towards each other than they did at present, and than revolutionary theories of social change demanded ${ }^{1022}$. His pleading for cooperation between members of all classes mirrored Henrietta Barnett's firm belief that only through mutual understanding, personal contact and friendship between the classes could society hope to thrive. "What is needed to save the cause of progress", Robertson postulated, "is a coalition between all the friends of just taxation, all the masters who care alike for economic science and for the elevation of their workers, and all the

\footnotetext{
${ }^{1018}$ Robertson, John Mackinnon, The Meaning of Liberalism, 1912, p. 250

${ }^{1019}$ Robertson, John Mackinnon, The Meaning of Liberalism, 1912, p.220

${ }^{1020}$ Robertson, John Mackinnon, The Meaning of Liberalism, 1912, p. 220

${ }^{1021}$ Robertson, John Mackinnon, The Meaning of Liberalism, 1912, p.120f

${ }^{1022}$ Robertson, John Mackinnon, The Meaning of Liberalism, 1912, p.221
} 
workers who can discern between practicable evolution and the planning of Utopias on paper."1023 The call was, of course, as much a rallying of support for the Liberal Party in the face of both new conservatism and the Labour Party, as it constituted an earnest appeal for peaceful social reconstruction.

\section{Universal Suffrage as the Only Acceptable System in an Ideal State}

On top of a rethinking of social relations as advocated above, Robertson aimed to cement the new sense of community through a reform of the political system of Great Britain. By contrast to Henrietta Barnett who believed a certain social hierarchy to be natural and useful Robertson ultimately aimed at equality. As long as workers and capitalists found themselves in so obviously unequal situations with regard to material comfort, equality of opportunity and social and political influence, Robertson pointed out, in vain would the labourers be asked to content themselves. Out of the confusion of the phenomena of class life, fed by revolutionary socialist propaganda as much as by old-fashioned conservatism, Robertson drew the conclusion that the only true moral title to membership in a social community, and the best guide to questions of support, sprang from the rendering of service. "Reciprocity of service is the ideal social condition" 1024 , he did not tire to repeat. On top of a certain re-balancing of material conditions which could be achieved through insurance and pensions, the idea of reciprocity also demanded social equality, Robertson argued. A failure to realise the latter, Robertson feared, would eventually lead to the demise of civilisation ${ }^{1025}$. In Robertson's eyes, the principles of reciprocity and equality of sacrifice involved the duty to enfranchise all those who contributed to the well-being of the community ${ }^{1026}$.

If a given adult was a working, wealth-creating, service rendering unit of society, Robertson specified, his non-enfranchisement was sheer inequality and an obvious injustice ${ }^{1027}$. "To exclude any such", he admonished, "is to belie the very principle of community, to refuse the first step towards doing as we would be done by in public life." ${ }^{1028}$ His plea for universal enfranchisement of working adults included women. Women made up at least half of the community. Robertson

\footnotetext{
${ }^{1023}$ Robertson, John Mackinnon, The Meaning of Liberalism, 1912, p.224

${ }^{1024}$ Robertson, John Mackinnon, The Meaning of Liberalism, 1912, p. 152

${ }^{1025}$ Robertson, John Mackinnon, Equality. A Discourse, 1886, p.42

${ }^{1026}$ Robertson, John Mackinnon, Equality. A Discourse, 1886, p.48

${ }^{1027}$ Robertson, John Mackinnon, The Meaning of Liberalism, 1912, p.100

${ }^{1028}$ Robertson, John Mackinnon, Equality. A Discourse, 1886, p.48
} 
considered it to be of the utmost importance that they should be trained to responsible citizenship $^{1029}$. He denounced Gladstone's dictum that a woman's proper sphere lay in the home as an insufferable hypocrisy. In reality, he pointed out, over a million women had no choice between working outside the home and starving. Also, women were already given the vote in municipal matters. Robertson considered it an absurdity that women should be recognised as valid members of the local community and be refused like recognition on a national level ${ }^{1030}$.

But even in this respect, Robertson admonished his readers to supplement state action by voluntary initiative and a private rethinking of values and habits. Total equality could not be enforced by legal measures such as total enfranchisement he maintained. It also required a change in personal attitude and a modification of the forms of intercourse between classes. People very much changed their pitch, Robertson observed, depending on whether they entered relations as buyers or sellers, master or servant, employer or employee. Consider, he invited his readers, the change of tone in a lady talking to her doctor or her maid respectively. "In each case, a service is commissioned, rendered and paid for", he explained; "but how different are the various intellectual and spiritual relations." 1031 The change in attitude was only partly a question of intellectual capacity. The betteroff retained respectful relations with stupid relatives and intellectually unfit members of their own classes in a spirit of equality, Robertson argued. The differential in respect between members of various classes constituted a remnant of feudal relations.

Master-servant relations, for instance, represented an application to the domestic problem of the autocrat theory of government which assumed that the majority of people were incurably unwise and therefore unfit to govern themselves ${ }^{1032}$. The same view tended to determine relations between husband and wife, Robertson pointed out. Unequal relations between people of sound mind and body, Robertson argued, degraded both parties taking part in such intercourse. "[T]hey are off the line of moral evolution" 1033 , he believed. Robertson called to his contemporaries to shed the ingrained prejudices, change their attitudes towards members of other social classes and to accept them as their equals in their capacity as contributors to the well-being of the nation. From such a change of attitude Robertson expected enormous moral and cultural returns: "To see the spiritual gain involved in equality, we have but to turn to the society of the United States and note the difference between it and our own"1034, he wrote. Cultural progress and increase in civilisation formed as important a part in the growth of a nation as did material gain, he reminded his readers.

\footnotetext{
${ }^{1029}$ Robertson, John Mackinnon, Vote for Women, no date, p.8

${ }^{1030}$ Robertson, John Mackinnon, Vote for Women, no date, p.7

${ }^{1031}$ Robertson, John Mackinnon, Equality. A Discourse, 1886, p.45

${ }^{1032}$ Robertson, John Mackinnon, Equality. A Discourse, 1886, p.49

${ }^{1033}$ Robertson, John Mackinnon, Equality. A Discourse, 1886, p.51

${ }^{1034}$ Robertson, John Mackinnon, Equality. A Discourse, 1886, p.52
} 
Robertson's starting point for his agitation for social reform was his belief that man was subject to an ongoing process of evolution and that in order to succeed in the "struggle against the struggle for existence", society needed the resources of all its members. It was in the community's best interest to help its members develop their capacities to the best of their abilities.

He believed that the first and absolutely essential precondition for letting all men fulfil their potential was to ensure that they enjoyed a comfortable standard of living and some degree of material security. At the same time, boosting the spending powers of a large section of the population would in Robertson's eyes also lead to an expansion of industry and commerce and thus produce even greater material wealth for the nation. Robertson therefore advocated a programme of redistribution by way of insurance schemes against unemployment and sickness, old age pensions and tax reform. Like Percy Alden and reminiscent of Headlam's demand for a single tax, Robertson demanded, among other things, a special tax on land values. These were measures which in Robertson's eyes should be handled by the state as agent of the community.

However, in Robertson's opinion, social reform to be successful required more than bureaucratic and mechanistic interference by the state. Like Henrietta Barnett, Robertson believed firmly that a true reform of society required the renewal of a spirit of community and mutual responsibility which had been lost under the present system of unlimited competition and private capitalism. He therefore called for his fellow-citizens to rethink their personal values and habits, to become thoughtful and deliberate consumers and to start treating each other as equals regardless of job, status or income. Robertson campaigned for universal suffrage, including women, as the only acceptable state in a reformed society. Also, he admonished his contemporaries to start taking on responsibility for the well-being of the community and to exercise prudence in family planning, firstly, so as not to strain over the limit the assets of society and secondly, so as not to make suffer and die surplus population for whom resources did not suffice.

In the concluding section of this study, I shall analyse and compare the ideas and arguments proffered by the seven thinkers whose thought we have examined in the foregoing chapters in an attempt to answer the question of whether or not Christian social reformers brought any particular aspects - either in terms of argumentation or policy proposals - to the contemporary debate on social reform. 


\section{Part III}

Conlusion and

Outlook 


\section{Chapter 9 - Conclusion}

Thinking back to the Introduction of the study, we remember that the question we set out to answer in this thesis was: what contribution, if any, did Anglican and Nonconformist theology make to the re-definition of the social question between 1880 and 1914? We went about finding out whether there were any points on which Christian thinkers generally differed from non-Christian reformers. Following an idea by the historian Peter d'Alroy Jones, in order to answer the questions we have in the previous chapters uncovered the social, political and economic thought of seven thinkers, four of them religious, three non-religious, who fell into the four categories of Christian socialists, socialist Christians, non-Christian socialists and anti-Christian socialist. In the concluding sections of the thesis, I shall juxtapose and compare the social theories of these seven thinkers in an attempt to draw out differences and congruencies in their thought, argumentative strategies and policy proposals and to answer the question about possible distinguishing marks of Christian social thinking.

\section{Congruencies and Intersections in the Grievances Addressed and the Proposed Remedies for Social Ills}

a) Intersections in the Grievances Addressed

A first glance at the thought of the seven thinkers reveals that it is difficult to establish a clear profile of Christian social thought, let alone one which could easily and profitably be compared to, and contrasted with, the equally heterogeneous theories voiced by the non-Christian thinkers in this study. Not surprisingly, for instance, the seven thinkers examined here show considerable overlap in the grievances they addressed and often lamented the same social and economic injustices which in their opinion underlay or made up the social problems of their times. These intersections do not allow for a clear differentiation between Christian and non-Christian thinkers.

All of the reformers under scrutiny here, for example, whether inspired by their Christian beliefs or not, in one way or another pointed to the error of distribution in material wealth in Great Britain and 
the destructive effects of mass poverty on national life and grandeur. The most pronounced stand on the question was, of course, taken by Leo George Chiozza Money. Through his analysis of Inland Revenue data, he brought before the public eye the shocking fact that eighty per cent of Britain's population lived in, or on the verge of, poverty. Clementina Black pointed an accusatory finger at wages too low for a worker's subsistence and impressed upon her readers that the practice of sweating had negative effects on the entire nation. A decade before them, John Robertson had noted that the maldistribution of income and material means constituted a grave impediment to economic expansion and therefrom developed his theory of underconsumption.

Among the Christian thinkers, Percy Alden showed himself concerned about the destructive effects of mass poverty on Britain's military and economic hegemony. He warned against building the British Empire on the insecure foundations of a population too poor to afford the most basic necessities. The Christian socialist Stewart Headlam took an ethical view on the problem of maldistribution. He pointed to the injustice of an economic system where the worker was the last in the chain of production to receive a share of his own labour's produce. He also complained of the injustices of a system of private ownership of land, an entity which in his opinion belonged by rights to the entire community. William Booth and Henrietta Barnett showed themselves particularly concerned about the impact of insufficient means on the physical and mental health of the individual. They argued that poverty corrupted the worker's physique as well as his moral strength and spirit.

Secondly, three of the thinkers examined here focused on the state of housing as an indicator of wealth and poverty. Of those, two, namely Henrietta Barnett and Percy Alden, were Christians, while the third, Chiozza Money, was not. All three came to the conclusion that the dens and hovels of the poor constituted as much a symptom as a cause of the great poverty among the majority of the British population. Alden stressed the fact that the system of unlimited competition had failed to provide adequate housing for the poorer sections of society. A serious house famine in great conurbations and exorbitant rents in industrial centres made it impossible for workers on or below a subsistence wage to acquire healthy and sizeable accommodation for themselves and their families. The result were the seriously overcrowded, insanitary and ugly slum districts of central London. Money, too, criticised that lack of resources forced large sections of society to live in houses unfit for human habitation. The insanitary and overcrowded dwellings of poor neighbourhoods affected the health of inhabitants. Alden and Money both pointed to the great discrepancies in death rates between wealthy parts of London and the slum districts of the East End. So did Henrietta Barnett who also stressed the negative effects of unhealthy, dirty, ugly and crowded neighbourhoods on their dwellers' moral and mental health. She held the airless, lightless and joyless housing of the 
poor accountable for the evils of drink, gambling and domestic violence among the working classes. Thirdly, an issue in many ways related to the problem of housing was that of social fragmentation or class divisions which reformers from both sides of the spectrum perceived as steadily increasing in turn-of-the-century Britain. The Christian reformer Henrietta Barnett believed that the geographic division into rich and poor neighbourhoods was accompanied by a cultural division and emotional distancing from both sides of the social spectrum. She feared the decline of communal relations between members of the various classes of society as they had once existed in the pre-industrial village. William Booth, also a religiously inspired reformer, lamented the breakdown of paternalist social relations. He held that mass urbanisation and the introduction of large-scale industrial production had robbed the worker of the guidance, example and protection of his social superiors which had been an integral part of social relations in rural settlements.

But social fragmentation was not only noted and lamented by the Christian reformers under scrutiny here. The a-religious Chiozza Money criticised a social set-up where the community fell into two groups, one toiling and the other idle, a sentiment with which the Christian headlam fully agreed. The obvious injustice of such a division endangered social peace, they both believed, a fact also acknowledged by the anti-Christian John Robertson. Headlam and Money called for a reorganisation of society which abolished the idling classes, demanded equal effort from every member of society and set all to work for the common good.

Fourthly, many of the thinkers under discussion, whether or not inspired by their religious creed, addressed the issue of education in their critique of contemporary British society. The non-Christian Chiozza Money and the Quaker Percy Alden both worried about the poor state of schooling in Britain as compared to her continental rivals, foremost among them Germany. They both drew a direct connection between the superior technical training of students in Germany and her increasing economic prowess. Money and Alden both feared that the present unsatisfactory British system of education produced an ignorant and uninventive workforce and placed Britain at a disadvantage in international competition. The non-Christian socialist Clementina Black expressed her concern about the educational disadvantage from which children suffered who were forced into early industrial employ. The Christian thinkers Stewart Headlam and Henrietta Barnett, too, showed themselves concerned about the level of education and the state of schooling in late-Victorian and early-Edwardian England. The anti-Christian Robertson used the inferior quality of British schooling to campaign for a containment of the influence of religious institutions on British society. The many intersections between Christian and non-Christian thinkers which we have sketched out above with regard to the grievances the addressed thus render the idea of a clear distinction between the two groups on these grounds impossible. 
b) Overlap between Christians and Non-Christians in Policy Proposals

As with regard to the grievances addressed, in their policy proposals and proposed remedies for the social problem, too, the seven thinkers showed considerable overlap which does not allow for a clear differentiation between Christian or non-Christian ideologies. Many policies appear and reappear in the thought of several of the reformers, whether or not they declared themselves inspired by their creed in their reformism.

In the matter of housing, for instance, all three reformers concerned with the issue, namely the Christians Barnett and Alden and the non-Christian Money, lauded the privately built model villages at Bournville, Port Sunlight and Saltaire. The settlements inspired Henrietta Barnett in her dream of Hampstead Garden Suburb, a private enterprise designed to bring the advantages of the village community into the industrial city. Percy Alden and Chiozza Money also considered garden cities and suburbs to be among the best forms of housing for the industrial working classes. But although they were appreciative of private effort such as Barnett's, both believed that poor housing harmed the community as much as it did the individual and that it should ultimately be the responsibility of governmental bodies such as the municipalities to solve the problem. They recommended conferring upon local governments the powers to act as landlords, to buy land, build tenements for the poorer strata of citizens and let them out at affordable rents.

On the issue of education, too, the socialist Christian Percy Alden and the non-Christian socialist Leo George Chiozza Money showed considerable agreement. They both urged their contemporaries to enforce compulsory schooling, raise the school leaving age and to include scientific and technical training in the national curriculum in order to produce a workforce fit for an internationally competitive industrial economy. The socialist Christian Barnett showed herself particularly concerned about the ignorant adult. She proposed a series of educative measures and facilities for grown-ups such as art galleries, libraries and evening schools in order to off-set the stunting and stultifying effects of repetitive machine labour and uniform, ugly neighbourhoods. The Anglican divine Stewart Headlam saw in free, comprehensive and compulsory education a means to remedy some of the excesses and limitations of a hierarchical society. He hoped that common schooling would lift every child into the place in life best suited to its particular gifts regardless of class or wealth. He intended to use the "people's schools" as instruments of social levelling.

Two of the thinkers under discussion, one Christian, one not, proposed to resort to extensive programmes of labour and factory legislation. Percy Alden presented a catalogue of individual policies, among them an eight hours day, compulsory registration in labour bureaux, municipal relief works and the establishment of a central Ministry of Commerce and Industry. Clementina 
Black also believed in the beneficial effects of such legislative measures. She postulated the introduction of a minimum wage and argued for wage or arbitration boards. She also demanded that the provisions of the existing Factory Acts be more strictly imposed and supervised. Both thinkers anticipated that such legislation would have an immediate beneficial effect on the health and material situation of the individual worker.

It is interesting to note, however, that their proposals for factory legislation were strictly opposed by two of the non-Christian thinkers in the present study. John Robertson warned forcefully against interfering directly with the trade cycle and tampering with the natural mechanisms of the economic system through measures such as a minimum wage or compulsory eight hours days. In his eyes, legislative intervention with the workings of industry and commerce was at best useless, and could at worst upset the entire balance of the nation's economy and lead to more misery and squalor. The non-Christian socialist Chiozza Money, too, expressed doubts about the efficacy of factory and labour legislation. He believed measures such as wage boards or labour bureaux to be, although not harmful, but still without effect in the face of the complex mechanisms of the economic machinery. Another proposal which recurred in the writings of Christian and non-Christian thinkers alike was the call for the establishment of a comprehensive national system of insurance against sickness, accidents and unemployment and the introduction of a national pensions scheme to counterbalance the greatest dangers and negative effects of an industrialised economy on the workers. The nonChristians Money and Robertson both argued that such systems would help to maintain spending powers and thus help stabilise the economy. The socialist Christian Percy Alden, too, included a system of insurance in his catalogue of measures against unemployment, although by contrast to Money and Robertson, he was reluctant to make it entirely state-run. The two non-Christian thinkers Robertson and Money favoured the introduction of a comprehensive old age pensions scheme on the grounds that, on top of being an economic asset, it constituted a dictate of social ethics: the worker who had spent his life in the service of the community was entitled to the community's support in times of need. The Christian Henrietta Barnett also called on her contemporaries to support the elderly with a pensions system. She lamented the loss of experience and expertise, the marketable wares of the aged, to the community under the present system where the old and incapacitated were locked away in the workhouse.

One proposal which was, among the limited sample of thinkers analysed here, discussed exclusively by Christian thinkers was the idea of labour colonies which took up much room in the writings of both William Booth and Percy Alden. The two Christian thinkers were also the only ones among our group of reformers who dealt at length with the problem of unemployment. However, it is difficult to ascribe to this fact any significance and employ it as an indicator as to the differences 
between Christian and non-Christian thought. In the Introduction we have seen that the idea of farm and labour colonies was current coin among social reformers at the time and experimented with by, for instance the Poplar Poor Law guardians and the London County Council.

c) Some Examples of Influences Apart from Religious Beliefs on the Social and Political Thought of the Reformers Examined

In the case of some policy proposals it is absolutely clear that it was not the influence or absence of a strong personal faith, but other allegiances and inspirations which caused the thinkers to advocate or reject them. Those among the thinkers in the present study who sympathised with or were members of the Liberal Party, for instance, whether Christian or not, all recommended tax reforms which anticipated or supported Lloyd George's proposals of 1909. Thus the Christian socialist Stewart Headlam called for a Single Tax on land values on a Georgeist model as early as the 1880s. The anti-Christian socialist John Robertson and the socialist Christian Percy Alden both took up the idea of a tax on land values. Like Headlam, they argued that land values were created by society and thus rightfully belonged to the community at large. For the non-Christian socialist Chiozza Money, the idea of a tax on land did not go far enough. He called for the appropriation by the state of large areas of land itself in order to house, feed and employ the population adequately. Robertson, Money and Alden supplemented their proposals for land reform by the idea of a graduated income tax. They aimed at the Smithean formula of equality of sacrifice in the matter of taxation. All four thinkers agreed that indirect taxes on necessities such as bread, tea and sugar were unjust as they taxed the poorer sections of society unduly harshly and should thus be abolished. Money recommended keeping indirect taxes on luxury goods such as tobacco and liquor.

Possibly also influenced by New Liberal ideology, the three thinkers Headlam, Money and Robertson considered the question of electoral reform and legal equality to be of central importance to the question of social reform. They all called for an extension of the franchise to include all working (male) members of the community. They believed that only a society of equals could prosper in the long run. Headlam and Robertson demanded to include women in the electorate. The question of electoral reform was, of course, not limited to members of the Liberal party: Henrietta Barnett and Clementina Black also campaigned for women's suffrage, although the issue did not take precedence in the writings examined in the foregoing study.

Apart from party allegiances, the argumentative strategies and the content of their respective social thought was also subject to variations depending on the period in time when the thinkers formulated 
and presented their theories. The writings examined in the thesis were published over a period of three and a half decades. In the course of this time, the framework of ideas and arguments which helped to shape the thought of these thinkers was modified to accommodate, for instance, the increase in knowledge and changes in the self-perception of society which saw itself increasingly confronted also with pressures from outside. Thus it is indicative of the growing awareness among the British public of continental competition that the three thinkers who made their main contributions to the re-definition of the social problem in the early 1900 s used foreign models of social reform in their analysis of the social question and their proposals for its solution.

Percy Alden, for instance, reported extensively on his continental experiences. He described Dutch and German labour colonies and pointed to Swiss and German models of unemployment insurance as positive examples to be emulated in Great Britain. He also mentioned the German system of technical education which he considered superior to British schooling. So did Leo Chiozza Money. Money saw a direct link between the growing German economic competitiveness and her comprehensive system of technical and scientific training. In 1908, he introduced into the House of Commons a Bill which sought to establish in Britain the Munich continuation schools system ${ }^{1035}$. Clementina Black reported on legislative measures in New Zealand and Australia. She analysed their systems of wage boards and arbitration boards and pointed out their respective advantages and disadvantages for the British cultural, social and economic set-up. Interestingly, William Booth, who gained considerable experience with foreign welfare measures through his internationally expanding Salvation Army in the course of the two decades of his writing, did not resort to the idea of an international policy transfer. He did not refer to, for instance, German, Scandinavian or USAmerican policy models in his writings, but sought a solution to the social question entirely within the British cultural and political context.

The above examples show that with regard to the grievances addressed and the policy proposals proffered it is impossible to delineate specifically Christian or non-Christian lines of argumentation. What is more, influences and allegiances like party membership or the time of writing appear to cause more definitive congruencies among the thinkers studied here with regard to the issues and individual measures discussed than did religious affiliations. In the following section, I will look at their attitudes to the poor and their views on the respective merits of state help or voluntarism which underlay their social reformist thought in order to see whether that these indicators show marked and clearly defined differences between the two groups of thinkers.

1035 Chiozza Money, Leo George, Things that Matter. Papers upon subjects which are, or ought to be, under discussion, 1912, p.223 


\title{
2. Voluntarism and State Help: A Carefully Negotiated Individual Balance
}

\author{
a) The Balance between Voluntary Effort and Governmental Responsibility
}

We remember from the Introduction that the period in question saw a re-balancing in the area of social support of voluntary initiative, whether in the form of self-help and mutual aid or of philanthropic endeavours, and a call for increased governmental responsibilities and state intervention. Maybe their respective preferences for voluntary measures or state aid could serve as a differentiator between Christian and non-Christian social thought? A close look at their reformist programmes as laid out in detail in the foregoing chapters quickly scotches the possibility: their willingness or unwillingness to employ state aid and the extent to which they were prepared to enlarge governmental jurisdictions cannot be used as an indicator to answer our question. When scrutinizing their writings it becomes clear that all thinkers examined here found their own balance between state aid and voluntarism which bears no obvious relation to their attitude towards Christianity.

The thinker who allowed for the greatest increase of responsibility and power on the part of the state and who largely ignored voluntarism in his writings was the non-Christian socialist Leo Chiozza Money. He believed firmly that only the state could be trusted to act in the interests of the entire community and he therefore proposed to entrust it with the ownership and management of the main means of large-scale production, including even the ownership of ideas and patents, as well as of land. His sweeping plans of nationalisation are unparalleled in this study. Modern readers will note, of course, that with his ideas on nationalisation he anticipated the much disputed Clause IV of the Labour Party Programme.

No less radical than his plans for public possession of industrial plants and land, and certainly highly controversial at the time, was the degree to which he was willing to hand over to the state responsibility for the nation's children. His proposals for maternity care, free milk supply, school meals and regular medical checks for children constituted a serious encroachment of the private sphere. Money was prepared to enlarge the powers of the state at the expense of personal rights and responsibilities of the individual citizen, those relating to their private family life, which most other reformers still considered sacrosanct.

The economic proposals of the Christian Socialist Stewart Headlam were also sure to have stirred up much controversy at the time. Headlam shied away from full-scale nationalisation and 
depossession. He did, however, nevertheless aim at getting the land as the main means of production under the control of the community and to restore to the people the whole of the value derived from land. By way of a single tax on land values he proposed to entrust the state with this task. It is interesting to note that the proposal for a single tax in his mind constituted an alternative, superior form of nationalisation, one which circumvented the problem of private property and still appropriated for the people control of, and profits derived from, the land. Headlam did not reject nationalisation as such, but believed that with the appropriation through the community of the land by way of a single tax, many other forms of nationalisation or measures such as the management through the state of mass production might become superfluous.

By contrast to Money, however, Headlam did not believe that extending the powers and responsibilities of the state would suffice to solve the social problem. In his writings Headlam kept admonishing his contemporaries to show personal initiative and to take up a life of active citizenship. Headlam's social programme rested, among others, on the idea that all members of society were tied to each other in Christian brotherhood. Although he did not dwell on specific proposals for voluntary work he therefore called to his audience to recognise their reciprocal responsibilities and to personally work towards a society based on mutual love and respect.

A thinker in the present study who resembled Headlam in his belief that working towards an improved society required both, state-induced reforms as well as personal initiative and a rethinking of social relations, was the anti-Christian John Robertson. Robertson held that the state could only ever hope to assist in the process of change. His policy proposals are therefore limited to specific aspects of the social question which in Roberston's eyes required some degree of coercion, namely the establishment of an insurance system for sickness and unemployment and tax reform to help with the redistribution of the nation's combined wealth. The other part of his social programme was made up by appeals to his contemporaries to change their attitudes and re-think their personal values and habits, for instance with regard to consumption and procreation. A true reorganisation of society could not be enforced by the state, but required personal effort and sacrifice on the part of the individual, Robertson believed.

In many respects, the ideas of the socialist Christian Percy Alden overlapped with Robertson's position on the benefits and limitations of state aid. Alden, too, believed that the state could not be used to tackle the roots of the social problem. It was in Alden's eyes too clumsy an instrument to rectify faults in the complex machinery of the nation's economy. Like his anti-Christian colleague Robertson, Alden believed that the state could only ever hope to assist in the process of change and to alleviate some of the suffering caused by the faulty economic and social systems. He held fast to a strong element of self-help and voluntary initiative. As we have seen, he was hesitant to support 
the idea of an entirely state-run system of insurance. and favoured a scheme where voluntary contributions to, for instance, trade union insurance programmes were augmented and matched by state subsidies.

But compared to Robertson who gave equal weight in his writings to a discussion of voluntary effort and state action, Alden dedicated most space to the discussion of measures to be undertaken by the state and local authorities such as, for instance, municipal housing schemes, the creation of additional employment through the government or a modest tax reform. His insistence, that poverty and unemployment were national problems, caused by flaws in the economic and social set-up of the nation, and therefore merited a national solution, entailed the acceptance of a state more powerful than approved of by Robertson.

By way of different mechanisms, but in a fearlessness reminiscent of Money and Headlam, the nonChristian socialist Clementina Black suggested to hand over to the state an unprecedented degree of control over the economic and social spheres. With her campaigns for a minimum wage she proposed to entrust it with the welfare of the most powerless members of the British workforce. It was a proposal which ran diametrically counter to the deeply ingrained maxim of laissez-faire which advocated that not only should the state refrain from interfering with the nation's economy, but also that in an industrialised economy, the individual be best left to his or or own devices and that each was responsible for his or her own fate.

It is important to remember, however, that at the same time as supporting the extension of state responsibility, in her social and political thought, Black retained a strong element of voluntarism and a belief in the superior value of labour combination and trade unionism. Even her proposals for wage boards and courts of arbitration relied on a certain degree of voluntarism as they required workers' representatives to offer their services on these bodies and thus presupposed a willingness on the part of the labourers to actively work for an improvement of their own situation.

The socialist Christian Henrietta Barnett believed that the social question was in part one of social division which had to be overcome by personal initiative and individual effort. She lamented the fragmentation of society which was in her eyes caused by huge differences in income and the housing situation. She feared the mutual estrangement of members of different classes and one of her declared aims in her reform programme was to close the gaps between the classes and bring the rich and the poor together in personal contact and class-transcending friendships. She called to her fellow-middle class women to organise "at homes" to the poor, and to volunteer in industrial schools in order to establish points of contact between the classes and to contribute to the re-tying of a reliable social network. Her Children's Country Holiday Fund, the Metropolitan Association for Befriending Young Servants, the Whitechapel Art Gallery, even Hampstead Garden Suburb were 
projects which had come into existence though personal initiative and relied heavily on private donations and volunteer work.

At the same time, however, she accepted and advocated an increase in the responsibilities and powers of the state. "We would (...) limit State action", she wrote, "wherever it interferes with the growth of manhood and womanhood in the nation, and enlarge its actions wherever it could assist this growth." 1036 She thus called for a reform of the Poor Law in order to give the state powers to restore the unemployed to industrial efficiency and advocated the introduction of a system of old age pensions. She accepted that the state should be entrusted with the care of the nation's orphans and pauper children and proposed measures such as her ideas on a new central authority commissioned to deal with all children under state care or her notions on a reform of barrack schools designed to improve and perfect such state aid. Barnett appreciated the efficiency, command of resources and persistence of effort shown by impersonal agents such as municipal authorities and government departments and was prepared to use the potential of state aid.

The thinker who appears most measured and reserved about the possibility of extending the jurisdictions of the state was William Booth. Booth believed that in social reform, voluntary agencies should be afforded a strong role and far-reaching influence. He argued for instance that the management of his scheme of labour colonies as proposed in In Darkest England should be entrusted to the Salvation Army. And yet, he, too, came to recognise the value of state help. The social legislation of the first decade of the twentieth century had convinced him that the state could be made a valuable ally to voluntary efforts at social reform. He ascribed to it qualities proper to an educator, caretaker and provider. He called for it to "come in with a stronger hand" 1037 than it had hitherto exhibited in social matters and to restore the poor to respectability and efficiency.

Thus, the degree to which the thinkers examined here were prepared to employ state aid in their social endeavours also appears an inadequate differentiator between Christian and non-Christian thought. There were too many intersections and similarities between individual thinkers, for instance between the non-Christian Money and the Christian Headlam or between the anti-Christian Robertson and the Christian Alden, to allow for any meaningful delineation. If their respective degree of radicalism with regard to their willingness to extend the the jurisdictions of the state seems unsuitable as a distinguishing mark between Christian and non-Christian thought, how about their social radicalism and their readiness to upset the hierarchical system of social classes?

\footnotetext{
${ }^{1036}$ Barnett, Samuel Augustus and Henrietta Octavia Rowland Barnett, Towards Social Reform, 1909, p.13

${ }^{1037}$ Booth, William, The Salvation Army and Poor Law Reform, 1909, p.55
} 


\section{b) Paternalists and Emancipators}

Reading the foregoing chapters, one is struck by the fact that the two thinkers least prepared to upset the balance of the traditional class structure were both Christian, namely Henrietta Barnett and William Booth. Mindful of Robertson's accusations against Christianity as a hoard of conservatism and a check on progress, it seems a possible lead in order to answer our question on the potential differences between Christian and non-Christian social thought to look at the degree to which the thinkers examined here were prepared to alter the hierarchical structure of social classes and whether in their programmes of social reform they aimed at emancipating the poor or at alleviating suffering only to a degree which would ensure social stability under the extant system of social organisation.

It is true that the Christians Booth and Barnett both did not aim at a fundamental restructuring of society, but contented themselves with alleviating the suffering of the individual poor. Both were paternalist in their attitude to the poor. Their aim of reform was not the political and social emancipation of the lowest strata of society, but the lightening of their misery and an improvement of their living conditions within the framework of a clearly hierarchical structure of society.

William Booth considered an authoritarian structure of social classes to be the only form of social organisation which ensured peace and harmonious relations. He adopted a top-down system of authority also for his Salvation Army and recommended it for the running of the labour colonies he proposed to establish. He lamented the demise of the rural village where rich and poor lived within the same community and the poor could draw guidance from the daily encounters with the rich. He saw society as an extended family where the well-off took over the role of parents, providing tutelage and direction through their own example or through gentle and loving disciplining.

Henrietta Barnett compared social classes to the hills and dales in a landscape which gave character and beauty to a country. For her, each class played a vital part in the running of the nation and could not be abolished if society were to remain stable. But although she was not prepared to let the poor rise above their station as she saw it, she actively demanded improved material conditions and better education in order to give them the opportunity to live the happiest and most fulfilled life possible in their social position. Also, Barnett called for an improvement of the situation of women in particular and an extension of their social and political rights.

However, the examples of Booth and Barnett do not suffice to ascribe to Christian social thought an ingrained conservatism and paternalism. Too forceful and vivid were the calls of the Christian Socialist Stewart Headlam for social equality and the social and political emancipation of the worker. In accordance with the non-Christian Money and the anti-Christian Robertson, Headlam 
aimed at a society built on the principle of true equality, an attitude possibly inspired, as we have surmised above, by their New Liberal leanings. Money and Headlam called for a reorganisation of society into a single class, the abolition of privilege and the universal duty to work. The idea of conservative remnants in Christian social thought is further called into question by the fact that Headlam justified his demand for equality with his conviction that equality was a tenet of Christianity which was celebrated and reaffirmed with every act of baptism.

Also, it is important to note that there appear elements in the thought of, for instance, the nonChristian thinker Chiozza Money which to the modern eye seem dated. Money demanded an end to a society where the life of the majority was determined by the idle few and called for a truly democratic country in which all had a say in its running and all would contribute to its upkeep. However, this may only have applied to male members of society as Money appeared reluctant to afford equal rights to women and saw the place of women in the house and family rather than the public sphere. We remember his statement, for example, that "[t]here is only one proper place of work for the married woman and that is her home."1038

\section{Individual versus Society: the Focal Points of Reform as Differentiator between Christian and Non-Christian Social Thought}
a) The Motivational Forces Behind the Social Reformism of the Writers Examined

"When people have asked me what is the difference between Christian Socialism and other Socialism", we remember Stewart Headlam writing, "I have been in the habit of saying that economically, there is no difference: that the motive power often is different and that we appeal to different people and on different grounds, but that the economic basis is the same." ${ }^{1039}$ We have seen in the foregoing sections that there were indeed many intersections between the grievances addressed, the policy proposals offered or their respective willingness to employ the help of the state in their social programmes. But we have also seen that contrary to what Headlam suggested, it is impossible from the sample of thinkers examined here to construct an economic basis of Christian social reformism, let alone one shared with non-Christian social endeavours.

\footnotetext{
${ }^{1038}$ Chiozza Money, Leo George, Riches and Poverty, 1905, p.169

${ }^{1039}$ Headlam, Stewart Duckworth, The Church and Socialism, 1890, p.220
} 
Headlam has, however, touched upon an important point when he wrote that the difference between Christian and non-Christian social thought lay in the motive powers behind it. Of course, the research question and design of this thesis make the idea somewhat obvious. In the following, however, we shall see that this difference between Christian and non-Christian reformers ran deeper than whether or not the thinkers resorted to their beliefs to justify their social endeavours. The articles and books examined here indicate that the values and concepts which the thinkers brought with them to their reformist endeavours impacted on both, the arguments behind their proposals and on the ultimate end at which they aimed with a reform of society and the economic set-up. The material of the present thesis suggests a continuum across the four categories of thinkers which ranged from a strong belief in the sanctity of humanity among Christian thinkers as the main concern in their social endeavours to a preoccupation with the health and well-being of the social body and a paramount emphasis on economic efficiency and expansion among the non-Christians. Stewart Headlam, William Booth and Henrietta Barnett derived their motivation for social reform from their Christian beliefs. Headlam argued that it was a dictate of Christian justice and of humanity that society needed to be reformed and the poor given better chances in life. He believed in the Fatherhood of God and a consequent brotherhood of men and criticised the present state of social, material and political inequality which in his eyes was unworthy of a society of brothers. He also held that by becoming man, Christ had sanctified all things human and had taught his followers that service towards one's fellow-man constituted the best possible service towards God.

William Booth's main motivation for social reform lay in the desire to free men from earthly troubles to liberate their souls and work towards their spiritual salvation. He believed that the material and physical hardship which the masses suffered occupied their minds and stood in their way to God and religion. The alleviation of poverty was thus in Booth's mind but an instrument: he hoped to thereby put the poor into a position to seek salvation and the afterlife. He acted on the simple formula that in order to save the soul, one had to first save the body.

Henrietta Barnett showed herself convinced that religion, the awareness of a force greater than any earthly authority, constituted the only motivational force which could bring man to make personal sacrifices and to engage in hard and possibly frustrating work towards social improvement over an extended period of time. Barnett shared Headlam's view that service towards one's fellow-men constituted the best possible form of service towards God; in her eyes as in Headlam's, a life of active citizenship and persistent toiling on behalf of one's less fortunate neighbours thus was a dictate of the good Christian life.

Headlam, Booth and Barnett all three believed in the sacredness of the individual. The overriding concern and focal point of their reformist endeavours was the empowerment of the individual 
person. We remember the vehemence with which Booth and Barnett in particular aimed at restoring to all men and women the dignity and self-respect of which poverty and destitution had robbed them. All three thinkers, Booth, Barnett and Headlam, pursued their social reform plans in order to enable every member of society to develop his or her potential to the fullest extent. The evolution of personality and individual capacity constituted in their eyes a Christian duty and an end in itself. Educational facilities, the provision of adequate housing and the offer of a place in a labour colony all fit in with the aim of getting the fallen back on their feet and enabling them to develop their full potential.

In Barnett's thought, however, one finds a second set of arguments of an economic nature. Complementarily to her belief in the sanctity and independent value of the individual, Barnett also had in view in all of her policy proposals the needs and the interests of the nation as a social, political and economic entity. She employed arguments which remind the reader of the debate on national efficiency of which we have heard in Chapter One of this thesis. She argued that poverty and its corollaries, the pauperisation of large sections of the population and the geographic, material and cultural fragmentation which attended mass poverty, harmed the nation socially and economically and put in danger its political stability. The disastrous physical condition of many of the poor, for instance, led to real economic loss through sickness, inefficiency, exhaustion and unemployability. We remember that Barnett proposed to replace the Poor Law formula of Less Eligibility with its punitive character with the principle of Industrial Efficiency which was meant to benefit not only the individual, but the whole community.

Poverty, poor health and very low levels of education, Barnett believed, held the nation back in its competitive race for international military supremacy and economic leadership. Barnett admonished her readers to take an interest in the children of the nation and to let them grow up into selfdependent, efficient, well-educated future citizens who could eventually contribute their share to the nation's growth and progress. Barnett aimed at making available the potential of all its citizens for the good of the nation: this is one of the reasons why she campaigned for old age pensions to take the aged poor out of the workhouse and make available to the general population their immense stock of knowledge acquired in the course of a lifetime as workers and parents.

The economic arguments were taken up by Percy Alden, the last among the Christian thinkers discussed in the foregoing chapters. Among the Christian reformers, he was the most economicallyminded and with his arguments on the economic origins of poverty forms an important link in the continuum between Christian humanitarianism and non-Christian belief in progress and social health. Alden believed that the mass poverty of nineteenth century Britain was a result of industrialisation. It stemmed from factors inherent in the economic system, fluctuations of trade, 
changes in production processes, the international state of the economy, rather than from the faults and moral failings of individuals. As a phenomenon of a-personal causation and national dimensions, in his eyes, it merited a national effort at solution.

Like Barnett, Alden's arguments echo some of the points made in the debate on national efficiency. $\mathrm{He}$, too, feared that the position of Britain at the forefront of the nations was threatened through mass poverty. He planned to create for every citizen of the British nation conditions which would allow him or her to play their parts as citizens of the Empire. Alden had travelled widely and in his reform endeavours employed an international frame of reference with an eye on international competition, but also on methods and measures which had been tried and tested in, for instance, Germany, the Netherlands and Switzerland and which had, in his eyes, given these nations an advantage over Britain in the respective areas of social policy. In his proposals, he drew on initiatives and policies which he had encountered during his travels such as the Dutch and German systems of labour colonies or the various Swiss attempts at unemployment insurance which he hoped to adapt and improve for application in Britain.

Clementina Black, the first of the non-Christian thinkers examined in this study, showed herself concerned about the destruction of potential and ability wrought by poverty. She exhibited much sympathy for the situation of individual workers and their families and emphasised the human misery caused by the present economic and social system. But her main argument against underpayment rooted in the notion that the destruction of the ability to work in the individual cost the community dearly, first through the loss of the individual's full labour and, secondly, through the follow-up costs of poor relief or expensive reforms.

In her attempts to justify her agitation for social reform, she introduced a new, biologistic aspect of society as a living organism to the debate. She invoked arguments that underpayment and poverty were detrimental not only to individual health, but also to the health of the body politic. She regarded underpayment as an organic disease of the social body which weakened the constitution of the entire community. Black likened poverty to a miasma which poisoned also the presumably healthy parts of the social corpus. The sweated worker constituted a menace to the health and prowess of the nation and drained resources, human as well as financial, which should be more profitably employed in the expansion of the nation's industry and commerce and its social and cultural growth. She feared that the practice of underpayment undercut the innovative potential and capacity for growth of the body politic and thereby further weakened its entire constitution and threatened not only present, but also future health.

The other extreme of the spectrum is represented in this thesis by the non-Christian and antiChristian thinkers Leo George Chiozza Money and John Mackinnon Robertson. While the Christian 
thinkers Headlam, Booth and Barnett aimed at an empowerment of the individual, Money and Robertson worked towards the empowerment, first and foremost, of society. Both believed that social reform was a dictate of reason in an ongoing process of human evolution in which mankind communally had to mobilise all its resources in the collective fight against the destructive forces of nature. They both held that the aim of human evolution, as well as mankind's best protection against extinction, lay in the growth of civilisation, an expansion of the nation's, rather than the individual's, cultural, moral, social and economic capabilities. Like Black, in their perception of mankind as part of the animal world, subject to the laws and processes of nature, they, too, showed themselves to be influenced by a biologistic view of social life.

By contrast to the Christian thinkers Headlam, Booth and Barnett, the non-Christian Chiozza Money largely excluded notions of the individual and humanity from his arguments. Individual man and woman figured in his writings only as basic "units of society". In Money's eyes, civilisation and its constant expansion constituted men's best insurance against death and extinction in the process of evolution to which all living creatures were subjected. And as civilisation was the outcome of communal life and effort, in his eyes, the community had a better chance at survival and triumph over the forces of nature than had the individual. Communal interests therefore in his thinking topped individual claims and personal rights as is illustrated, for instance, by his willingness to entrust the nation's children to the state and his campaigns for nationalisation.

John Robertson's central concern in his proposals for social reform was also the national community and its capacity for progress, growth and expansion. He believed that mankind had successfully mastered the stage in the evolutionary process where it had to struggle for existence. In his opinion, the new challenge for man now read struggle against the struggle for existence, a combat against relegation back to the primary stage of evolution and a fight for future progress. Man was no longer battling for survival, but struggling to keep his position one step above this elementary fight. In order to achieve the best possible position for the British nation in the struggle against the struggle for existence, Robertson hoped to extinct poverty and to place everyone in a position to develop his or her creative, innovative and wealth-creating potential.

Although Robertson's focal point was clearly society and the aim of reform a maximisation of the community's ability for progress, however, it is important to remember that by contrast to Money, Robertson took into account the individual and his or her role in his proposals for reform. While Money left it to the state to act as the agent of communal interest, Robertson appealed to all members of society to recognise their mutual responsibilities and their dependence one upon the other. He hoped to teach men to abandon their competitiveness and their selfish instincts and to pool their resources in order to work together against the forces of nature and improve their chances in 
the evolutionary process. The maxims underlying his vision of social life read "equality of sacrifice" and "reciprocity of service". Therefore, in his reform proposals, Robertson recognised that the individual not only had duties towards the community, but could insist on a certain amount of reciprocal care in return. This idea inspired, for instance, Robertson's call for old age pensions.

b) The Economic Argument for Reform and the Theory of Underconsumption

The idea of a continuum from an emphasis on the sanctity and independent worth of the individual, as exhibited in particular by the Christian thinkers Headlam, Booth and Barnett, to an overriding concern for the social, cultural and economic progress of society and Britain's international economic and military competitiveness, as shown in increasing urgency by Alden, Black, Money and Robertson, is supported also by the fact that it was the latter four who employed arguments derived from the new developments in economic theory and revealed themselves to be students of new political economy. All four justified their proposals for social reform with, among other ideas, statements and explanations which Robertson merged in his theory of underconsumption, lines of thought which were absent from the writings of Stewart Headlam, William Booth and Henrietta Barnett.

The socialist Christian Percy Alden quoted John Hobson and Albert Mummery's seminal textbook The Physiology of Industry to the effect that the fluctuations in trade and the instability of the market were to a certain extend due to the failure of the majority of the British people to keep up their standard of consumption. He hoped that a reform of the system of taxation coupled with the introduction of insurance against unemployment might help to boost the purchasing powers of the working classes and contribute to a stabilisation of the nation's economy.

Clementina Black employed similar arguments when she campaigned for the introduction of a minimum wage. Underpaid labour, she held, had no resources to consume more than the bare essentials and sometimes not even those. She believed that a rise in the rate of wages would immensely increase the capacity for consumption of a very large section of the population and thereby boost the nation's economy. She even went as far as to denounce thrift, a core value of Victorian society, as harmful to both the individual and the nation as it diverted funds away from consumption and thereby slowed down economic expansion.

Money underpinned his argument for increased consumption with his calculations on the Error of Distribution. The misallocation of material means in British society meant that the majority of the population lacked the resources necessary to maintain their health and strength, while a small 
percentage of the British people commanded more means than they could possibly spend. We remember that Money's calculation that a household of five could easily consume cotton goods worth $£ 4$ a year if only they had sufficient funds while the current imbalance of means meant that on average, such a household bought cotton produce worth only about 40s. The cotton industry, like all other industries producing necessaries, thus suffered immensely and directly from the maldistribution of means and the curtailment of spending power among the poor.

Robertson offered the most elaborate exposition on the problem of underconsumption. We have seen that in Robertson's eyes, saving was both illusory and harmful, both to the individual and to the nation. He countered the Smithean notion that some degree of saving was a necessary precondition of economic growth by claiming that in a fully developed industrialised nation, not the ready availability of additional capital, but the rate of consumption and demand regulated the rate of economic expansion and the stability of trade and commerce. He pointed out that economic progress depended on the opening up of new markets and admonished his readers to start by developing the home market.

The emphasis on the economic aspects of the social question set the above four thinkers clearly apart from the Christian reformers Headlam and Booth who paid little attention in their own writings to the mechanisms of the market.

c) Equality of Opportunity versus Re-Distributive Justice: A Denominator of Christian versus NonChristian Thought?

In the foregoing sections we have made out a continuum among the seven thinkers studied here from the individual to society as focal points and prime beneficiaries of reform and from the idea that reform was a dictate of humanity and the right of those living in poverty to the conviction that its main purpose was to maintain Britain's hegemonic position among the nations and to maximise her potential for progress and civilising growth.

The different emphasis on the individual or the community as basic units and beneficiaries of social reform may have caused a divergence among the thinkers in their respective notions of society. Headlam and Booth, the two clerics among the reformers, envisaged society as a brotherhood of men where each was his or her brother's keeper; the non-religious thinkers, on the other hand, especially Money and Robertson emphasised the contractual character of social relations. For Booth and Headlam, the alleviation of poverty and destitution constituted a moral imperative. Money and Robertson justified social reform with the covenanted principles of "reciprocity of service" and 
"equality of sacrifice". Similarly, while the Christian thinkers, especially Headlam, Booth and Barnett, spoke of the poor in need of reform as individuals, as persons in their own right, the nonChristians Robertson and Money tended to regard them as citizens, as parts of the political body of the British nation and as partakers in a social contract.

The dissimilarities in the focal points and ultimate aims of reform between Christian and nonChristian thinkers may also have influenced their respective views of the state. In the thought of the two non-Christians John Robertson and Chiozza Money, one notices the assignation to the state of the role of administrator, the collector of taxes and manager of insurance systems as well as, in the case of Money, the role of prime capitalist and manager of the nation's economy. In William Booth's writings one encounters a different view of the state. The social legislation of the first decade of the twentieth century had convinced him that the state could be made a valuable ally to voluntary efforts at social reform. He ascribed to it qualities proper to an educator and provider. Henrietta Barnett included in her social writings proposals on how to improve (and personalise) the state's care for orphaned and pauperised children and thence like Booth counted on it as an educator and provider. As with most other aspects discussed so far, the divergence is, however, far from absolute: Clementina Black, too, proposed to entrust the state specifically with the protection of the weakest members of society, the women and children in sweated employment, and thereby ascribed to it to a certain extent the functions of protector and caretaker.

Against the background of these possible differences in the view of society as a brotherhood or a contractual community and of the state as administrator or carer, one may read into their respective catalogues of reform proposals a certain bias towards fiscal and redistributive measures on the part of the non-Christian thinkers and to non-financial benefits and service-based measures on the part of the Christian reformers.

The material analysed in the foregoing chapters offers evidence to support the idea to a certain extent: Stewart Headlam, William Booth, Henrietta Barnett and even Percy Alden gave much room and thought to measures which aimed at empowering the individual, at giving back to the men and women their dignity and humanity and to help them lead an independent, self-supporting life. Stewart Headlam and Henrietta Barnett, for instance, devoted considerable space in their writings to the issue of educational reform. They aimed to equip the children - and adults - of the nation with the skills and knowledge necessary for an intellectually and emotionally fulfilled life and at the same time also required in a competitive labour market. Percy Alden and Barnett ascribed great importance to housing reform. Through sanitary surroundings and humane habitations they sought to restore the workers and their families, especially the children, to health and efficiency and to provide them with dignified surroundings. Through labour colonies and municipal relief works, 
Alden and William Booth proposed to offer work to the unemployed and thereby to enable them live an independent, self-supporting life.

The secular reformers, on the other hand, aimed in many of their proposals at rectifying the error of distribution through fiscal reform. Clementina Black called for a minimum wage in an attempt to distribute more fairly the profits derived from industrial production. John Robertson and Leo Chiozza Money demanded a comprehensive system of insurance against unemployment and a national old age pensions scheme. More radically, Robertson and Money propagated far-reaching reforms in the system of taxation including taxes on unearned increment and a graduated income tax. Money went as far as to postulate the de-possession of the private capitalist and the nationalisation of all means of large-scale production.

However, we have seen earlier that there were considerable intersections between Christian and non-Christian thinkers with regard to policies proposed. The division between Christian thought and a commitment to equality of opportunity on the one hand and of non-Christian thinkers and redistributive measures is by no means absolute. As we have seen, the secular reformer Money concerned himself with the issues of education and housing reform. Although he favoured redistributive measures in reforms designed to benefit adults, he was prepared to offer the nation's children any service-based measure such as medical care, school meals and, very prominent in his writings, education which would improve and enlarge their life chances (and through them, the potential gain to the nation). The Christian socialist Henrietta Barnett, on the other hand, recommended redistributive old age pensions. Percy Alden included in his catalogue of measures against unemployment tax reform and unemployment insurance. Most forcefully among the Christian thinkers, Stewart Headlam also worked for a redistribution of material means through his pioneering campaigns for land reform which, besides the issue of education, formed the main plank of his social agenda.

The possible bias in terms of emphasis on and space devoted to redistributive versus supportive measures in the thought of non-Christian and Christian thinkers respectively thus requires further corroboration (or refutation) through the study of a larger sample of Christian and non-Christian reformers. 


\section{Outlook - Christian Socialism a Hundred Years On}

In Britain, Christian socialism returned to the national news in recent years with the accession to party leadership of two successive Labour leaders who professed themselves indebted to it. The two were John Smith and Tony Blair. Both are members of the Christian Socialist Movement (CSM), the interconfessional Christian socialist body affiliated to the Labour Party which formed in 1960.

Tony Blair claimed a particularly strong commitment to CSM values, ideas and traditions. In the famous interview with Matthew d'Ancona for the Sunday Telegraph's Easter edition of 1996, he mentioned among the intellectual and moral influences on his political ideology not only the present day CSM, but also R. H. Tawney ${ }^{1040}$ and William Temple ${ }^{1041}$, both products of the Christian socialist era examined in the present thesis. Temple and Tawney had both been members of the Christian Social Union during their student days at Balliol. In 1903, they both spent several months at Toynbee Hall, where they became involved with F. D. Maurice's Workers' Educational Association and the Children's Country Holiday Fund of Henrietta Barnett. Both integrated into their selfperception as Christians a strong element of political activism and communal responsibility. In the inter-war period and again after World War Two, they became figureheads of Christian socialism. In 1942, as Archbishop of Canterbury, William Temple presented Britain with a vision of a just postwar society in his book Christianity and Social Order ${ }^{1042}$. His friend R. H. Tawney helped to formulate the policies and positions of the Labour Party in the inter-war period.

When explaining his political creed, Tony Blair frequently resembles the Christian socialist thinkers of turn-of-the century Britain in his choice of subject and phrasing. Blair, and his Christian socialist comrades-in-arms in New Labour, among them John Smith, Jack Straw, Gordon Brown, and Tessa Jowell, set out to re-moralise socialism. Blair frequently testified that a new-found belief in Christ and the Bible during his student days at Fettes, Oxford, prompted him to rid his socialism of Marxist remnants. Socialism to him became "a moral purpose to life; a set of values, a belief in society, in cooperation, in achieving together what we are unable to achieve alone" ${ }^{1043}$. In language reminiscent of Stewart Headlam and William Booth he told the Labour Party Conference in 1995

\footnotetext{
${ }^{1040}$ Richard Henry Tawney (1880 - 1962) was an economist, historian and social critic. From 1917 onwards he was lecturer and later professor for economics at the London School of Economics. He is the author of, among other books, the influential study Religion and the rise of capitalism: a historical study, which he published in 1926. See Tawney, R. H., Religion and the rise of capitalism: a historical study, 1926

${ }^{1041}$ William Temple (1881 - 1944), was an Anglican cleric and Archbishop of Canterbury from 1942 to his death in 1944.

${ }^{1042}$ Temple, William, Christianity and social order, 1942

${ }^{1043}$ Wilkinson, Alan, New Labour and Christian Socialism, 1999, p. 48
} 
that he considered himself "my brother's keeper": "[Your] child in distress is my child, your parent ill and in pain, is my parent: your friend unemployed or helpless, my friend." ${ }^{1044}$ Blair identified equal worth of all members of society, mutual responsibility and a sense of community as the values at the core of his political creed. He manifested the right of every citizen to be treated with equal respect and consideration despite their differences ${ }^{1045}$. In wording that could have been taken straight out of Headlam's writings, he told the public of his belief that the self was best realised in community with others, a "principle the Church celebrates in the sacrament of communion"1046.

Tony Blair's term of office was characterised by a shift from the post-war re-distributive social welfare state to what social policy experts have termed the social investment state. It is a shift which to some extent supports our earlier conjecture that there might be a link between Christian social thought and supportive rather than redistributive welfare measures. With his Third Way, Blair navigated a middle course between neoliberalism and the soon-to-be-bankrupt welfare model of post-war Britain. With his accession to party leadership, he ditched Labour's old commitment to nationalisation and re-wrote Clause IV of the party programme to emphasise his belief in the possibilities of community and, an aim also to be found among the Christian thinkers examined in this study, the empowerment of the individual. New Labour's social state aims at investment in human and social capital, the development of capabilities which "enhance[s] people's capacity to participate" 1047 . The change of focus involves a shift from the maxim of equality of outcome which underlay the post-war re-distributive welfare model to a concept of equality of opportunity focusing on the (re-)allocation of capabilities and life chances ${ }^{1048}$. New Labour aims at combating social injustice not primarily through material redistribution, but by increasing educational and employment opportunities, reforming the eroded National Health Service and strengthening the family and social communities. With its "welfare to work" programme, New Labour has set out to get especially young unemployeds off welfare and into the labour market. Their move away from redistributive measures as central policies of the welfare state, their dedication to drawing out and developing the individual's capabilities, their emphasis on education and their willingness to offer state support in matters of employment, health and housing places New Labour in the ideological vicinity of the Christian thinkers examined in the present thesis and corroborate Blair's claim to a Christian Socialist inheritance.

With the new emphasis on asset-based policies, children and young people moved into the center of focus of the British social investment state. In his Beveridge Lecture of 1999, Blair promised to

\footnotetext{
${ }^{1044}$ As quoted in Wilkinson, Alan, New Labour and Christian Socialism, 1999, p.47

${ }^{1045}$ Blair, Tony, PM's speech to the Christian Socialist Movement at Westminster Central Hall on March 29th, 2001

1046 Stelzer, Irwin M., Christian Socialism in Britain, 1996

${ }^{1047}$ Perkins, Daniel, Nelms, Lucy and Paul Smyth, Beyond neo-liberalism: the social investment state?, 2004, p.3

${ }^{1048}$ Perkins, Daniel, Nelms, Lucy and Paul Smyth, Beyond neo-liberalism: the social investment state?, 2004
} 
eradicate child poverty by 2020 . His chancellor Gordon Brown supported the re-thinking on the primary targets of social expenditure. Abolishing child poverty appeared to him to be "the best antidrugs, anti-crime, anti-deprivation policy for our country"1049. The prevention of material deprivation at an early age, the improvement of social assistance payments for children, the child trust fund, educational reforms and the strengthening of the family through measures like tax credits all aim at obscuring structural distinctions such as class, race or gender and combined to ensure that all "children get a good start in life"1050. The focus on children can be found also in the social thought of several thinkers under discussion here, Christian as well as secular. Headlam, Barnett and Money all placed great emphasis on their well-being. Their concern, and that of many other politicians and reformers since, was taken up by New Labour. In Blair's words, children constituted " $100 \%$ of our future"1051.

It is at this point, however, that Blair's social policy and social thinking appear to depart from the reasoning of the Christian Socialists under discussion here. A Strategy Audit of 2003, drawn up by the government's Strategy Unit, underlines the "cost-effectiveness of targeted investment in children" 1052 . New Labour regards children as the citizen-workers of the future. Future productivity in paid employment is thereby ranked among the primary obligations of citizenship. The social policy expert Ruth Lister, among others, criticises that with its social policy programme, New Labour targets those children and young people who show promise to contribute to national wealth and the growth of the economy in adult life. Children whose future contribution remains somewhat doubtful, such as handicapped children or young asylum seekers, do not benefit to the same degree from the new policy measures. In their emphasis on cost-effectiveness and the future pay-off of policy measures through paid work and contributions to national wealth, New Labour appears closer to thinkers such as Leo George Chiozza Money or John Robertson with their emphasis on communal welfare and national progress. New Labour's slogan of "no rights without responsibilities" reminds the reader of Money's and Robertson's contractual idea of a social community and may suggest analogies to their emphasis on the principles of "reciprocity of service" and "equality of sacrifice".

Lister criticises New Labour for perceiving children primarily as national assets. She demands that "the Government's emphasis on children as investments needs to be balanced by a more explicit appeal to principles of social justice and to the human rights of children qua children"1053. The focus

\footnotetext{
${ }^{1049}$ Lister, Ruth, Children (but not women) first: New Labour, child welfare and gender, 2006, 317

${ }^{1050}$ Childcare Strategy Document 2004, as quoted in Lister, Ruth, Children (but not women) first: New Labour, child welfare and gender, 2006 p.317

${ }^{1051}$ Lister, Ruth, Children (but not women) first: New Labour, child welfare and gender, 2006, p.316

${ }^{1052}$ Lister, Ruth, Children (but not women) first: New Labour, child welfare and gender, 2006, p.317

${ }^{1053}$ Lister, Ruth, Children (but not women) first: New Labour, child welfare and gender, 2006, p.330
} 
on their life chances (and their future contributions to the national wealth) needs in her view to be complemented by an equal concern for their present needs and their well-being as children. From the evidence uncovered in this thesis it appears that Lister's demand for a human dimension to social policy would yet have to be fulfilled in order to truly justify the claims of Blair's New Labour to a Christian socialist heritage. 


\section{Bibliography}

Fabian tracts nos. 1-186; published by the Fabian Society from 1884 to 1918 . London: Fabian Society, 1918.

Oxford Dictionary of National Biography. Oxford et al.: Oxford Univ. Press, 2004.

Alden, Percy. The Unemployed. A National Question. London: King, 1905.

Alden, Percy, and Edward Hayward. Housing. Social Service Handbooks; No. 1. London: Headley Bros, 1907.

Alden, Percy, and Charles F. G. Masterman. Democratic England. New York: Macmillan, 1912.

Ausubel, Herman. "General Booth's Scheme of Social Salvation." American History Review 56.3 (1951): 19-25.

Bailey, Victor. "In Darkest England and the Way Out.: the Salvation Army, social reform and the Labour movement, 1885-1910." International Review of Social History 29 (1984): 133-71.

Barker, Rodney. Politics, Peoples and Government. British History in Perspective. New York: St. Martin's Press, 1994.

Barnett, Henrietta Octavia Rowland. What has the Charity Organisation Society to do with Social Reform. London: 1884

Barnett, Henrietta Octavia Rowland. The Making of the Home. A Reading-Book of Domestic Economy, etc. London: 1885.

Barnett, Henrietta Octavia Rowland. "Science and City Suburbs." Science in Public Affairs. Ed. J. E. Hand. London: George Allen, 1906.

Barnett, Samuel Augustus, and Henrietta Octavia Rowland Barnett. Practicable Socialism. London: Longmans, 1894.

Barnett, Samuel Augustus, and Henrietta Octavia Rowland Barnett. Towards Social Reform. London: T. Fisher Unwin, 1909.

Beilharz, Peter. Labour's utopias: Bolshevism, Fabianism, Social Democracy. London: Routledge, 1992.

Beilharz, Peter and Chris Nyland. The Webbs, Fabianism and Feminism: Fabianism and the political economy of everyday life. Aldershot: Ashgate, 1998.

Bellamy, Joyce Margaret, and John Saville. Dictionary of Labour Biography. ed. by Joyce M. Bellamy and John Saville. Vol. 3. London et al.: Macmillan, 1976. 
Besant, Annie Wood, and Geoffrey West. Annie Besant: An Autobiography. London: Fisher Unwin, 1893.

Biagini, Eugenio F., and Alastair J. Reid. Currents of Radicalism: Popular Radicalism, Organised Labour and Party Politics in Britain, 1850-1914. Cambridge: Cambridge University Press, 1991.

Binyon, Gilbert Clive. The Christian Socialist Movement in England. London: 1931.

Black, Clementina. The Rhyme of the Factory Acts. London: Women's Industrial Council, no date.

Black, Clementina. An Agitator. [A Novel.]. London: Bliss, Sands; Co., 1894.

Black, Clementina. "Some Current Objections to Factory Legislation for Women." The Case for the Factory Acts. Ed. Sidney Mrs. Webb. London: Grant Richards, 1902.

Black, Clementina. Sweated Industry and the Minimum Wage. London: Duckworth, 1907.

Black, Clementina. "Legislative Proposals." Women in Industry from Seven Points of View. Ed. David James Shackleton. London: Duckworth, 1908.

Black, Clementina and Adele Meyer. Makers of Our Clothes: A Case for Trade Boards. Being the Results of a Year's Investigation Into the Work of Women in London in the Tailoring, Dressmaking, and Underclothing Trades. London: 1909.

Blair, Tony. PM's Speech to the Christian Socialist Movement at Westminster Central Hall on March 29th, 2001. 2001. http://www.number10.gov.uk/output/Page3243.asp

Booth, Charles. Life and Labour of the People in London. London: Macmillan and Co., 1892.

Booth, William. In Darkest England and the Way Out. London: International Headquarters of the Salvation Army, 1890.

Booth, William. A Talk with Mr. Gladstone at His Own Fireside. London: The Salvation Army, 1897.

Booth, William. Emigration and the Salvation Army. London: The Salvation Army, 1906.

Booth, William. The Salvation Army and Poor Law Reform. London: The Salvation Army, 1909.

Briggs, Asa, and Anne Macartney. Toynbee Hall. The first hundred years. London et al.: Routledge [and] Kegan Paul, 1984.

Bryant, Christopher. Possible Dreams. London et al.: Hodder und Stoughton, 1996.

Campbell, John L. Institutional Change and Globalisation. Princeton and Oxford: Princeton University Press, 2004.

Carpenter, Edward. England's Ideal. Manchester: John Haywood, 1885. 
Carter, Matt. T. H. Green and the Development of Ethical Socialism. British Idealist Studies, Series 3, Green. Vol. 1. Exeter et al.: Imprint Academic, 2003.

Chiozza Money, Leo George. British Trade and the Zollverein Issue. London: Sell, 1902.

Chiozza Money, Leo George. Elements of the Fiscal Problem. London: 1903.

Chiozza Money, Leo George. Riches and Poverty. London: 1905.

Chiozza Money, Leo George. 100 Points for Free Trade. Socialist and Labour Thought in Britain since 1884. 1908/40. London: 1908.

Chiozza Money, Leo George. Insurance versus Poverty. With an Introduction by the Right Hon. David Lloyd George. London: 1912.

Chiozza Money, Leo George. Things that Matter. Papers upon Subjects which are, or ought to be, under Discussion. London: 1912.

Chiozza Money, Leo George. Hope for the Worker. With An Introduction by Brother Richard. Leeds: 1913.

Chiozza Money, Leo George. The Immortal Purpose, and Other Poems. London: Richard CobdenSanderson, 1924.

Chiozza Money, Leo George. Sonnets of Life. London: R. Cobden-Sanderson, 1932.

Clifford, John. Socialism and the Teaching of Christ. Fabian Tract; No. 78. [S.1.]: Fabian Society, 1906.

Clifford, John. Socialism and the Churches. Fabian Tract; No. 139. London: Fabian Society, 1908.

Collini, Stefan. Public Moralists. Oxford: Clarendon, 1991.

Cox, Jeffrey. The English Churches in a Secular Society. New York; Oxford: Oxford University Press, 1982.

Creedon, Alison. "A Benevolent Tyrant? The Principles and Practices of Henrietta Barnett (18511936), Social Reformer and Founder of Hampstead Garden Suburb." Women's History Review 11.2 (2002): 231-252.

Currie, Robert, and Alan D. Gilbert. Religion. Trends in British Society Since 1900. 1972. 407-450.

Currie, Robert, Gilbert, Alan D., and Lee Horsley. Churches and Churchgoers: Patterns of Church Growth in the British Isles since 1700. Oxford: Clarendon Press, 1977.

Curthoys, Mark C., and Tim Wales. "Percy Alden." Oxford Dictionary of National Biography 1 (2004): 609-11.

Dekkers, Odin. J. M. Robertson.Rationalist and literary critic. Brookfield, Vt et al.: Ashgate, 1998. 
Dell, Edmund. A strange eventful history: democratic socialism in Britain. London: Harper Collins, 2000.

Den Otter, Sandra M. British Idealism and Social Explanation: A Study in Late Victorian Thought. Oxford Historical Monographs. Oxford: Clarendon, 1996.

Desai, Radhika. Intellectuals and Socialism: 'Social Democrats' and the Labour Party. London: Lawrence, Wishart, 1994.

Dicey, Albert Venn., and Emlyn Capel Stewart Wade. Lectures on the Relation Between Law und Public Opinion in England During the Nineteenth Century. Papermac. Vol. 20. London: Macmillan, 1962.

Dobbin, Frank. Forging Industrial Policy: The United States, Britain, and France in the Railway Age. New York: Cambridge University Press, 1994.

Eagar, Waldo McGillycuddy. Making Men.The history of boys' clubs and related movements in Great Britain. London: University of London Press, 1953.

Eden, William Arthur. "Hampstead Garden Suburb 1907-1957." Journal of the Royal Institute of British Architects (1957): 489-495.

Esping-Andersen, Gòsta. The Three Worlds of Welfare Capitalism. Cambridge: Polity Press, 1990.

Flora, Peter, and Jens Alber. "Modernization, Democratization and the Development of Welfare States in Western Europe.", in: The Development of Welfare States in Europe and America. Ed. Peter Flora, and Heidenheimer, Arnold. New Brunswick: Transaction Publ, 1981.

Flora, Peter, and Arnold J. Heidenheimer. „The Historical Core and Changing Boundaries of the Welfare State“, in: The Development of Welfare States in Europe and America. Ed. Peter Flora, and Heidenheimer, Arnold. New Brunswick: Transaction Publ, 1981.

Flora, Peter and Arnold Heidenheimer (eds.). The Development of Welfare States in Europe and America. New Brunswick: Transaction Publ, 1981.

Fox, Stephen N., and Clementina Black. The Truck Acts: What They Do, and What They Ought to Do. London: Women's Trade Union Association, 1894.

Frankel Paul, Ellen. Moral revolution and economic science: the demise of laissez faire in nineteenth-century British political economy. Westport, Conn; London: Greenwood, 1979.

Freeden, Michael. New Liberalism: an ideology of social reform. Oxford: Clarendon Press, 1978.

Freeden, Michael. Minutes of the Rainbow Circle. Camden Fourth Series. Vol. 38. London: Offices of the Royal Historical Society, University College London, 1989.

Freeman, Mark. Social investigation and rural England, 1870-1914. Woodbridge: Boydell Press, 2003.

George, Henry. Progress and Poverty. London: 1881. 
Gilbert, Alan D. Religion and society in industrial England: church, chapel and social change, 1740 - 1914. London: Longman, 1976.

Gladstone, David (ed.). Before Beveridge. Welfare Before the Welfare State. London: Institute of Economic Affairs, 1999.

Glage, Liselotte. Clementina Black: A Study in Social History and Literature. Anglistische Forschungen; Heft 156. Heidelberg: Winter, 1981.

Goldman, Lawrence. Science, reform and politics in Victorian Britain : the Social Science Association, 1857-1886. Cambridge: Cambridge University Press, 2002.

Gore, Charles. Lux Mundi: A Series of Studies in the Religion of the Incarnation. [S.1.]: John Murray, 1890.

Gorsky, Martin. Patterns of Philanthropy. Royal Historical Society Studies in History. Woodbridge et al.: Royal Historical Society et al., 1999.

Gould, Peter C. Early Green Politics: Back to Nature, Back to the Land, and Socialism in Britain, 1880-1900. Brighton: Harvester, 1988.

Grafton Green, Brigid. Hampstead Garden Suburb 1907-1977. London: Hampstead Garden Suburb Residents' Association, 1977.

Green, David G. "The Friendly Societies and Adam Smith Liberalism." Before Beveridge. Welfare Before the Welfare State. Ed. David Gladstone. London: Institute of Economic Affairs, 1999.

Green, Roger Joseph. The Life und Ministry of William Booth. Nashville, Tenn: Abingdon Press, 2005.

Haggard, H. Rider. Regeneration Being an Account of the Social Work of the Salvation Army in Great Britain. London: Longmans Green and co, 1910.

Haggard, Robert F. The persistence of Victorian liberalism: the politics of social reform in Britain, 1870-1900. Westport, Conn., et al: Greenwood Press, 2001.

Hand, James Edward (ed.). Science in public affairs. London: Allen, 1906.

Hannam, June, and Karen Hunt. Socialist Women. London et al.: Routledge, 2002.

Harris, Bernard. The Origins of the British Welfare State. London et al.: Palgrave, 2004.

Harris, Jose. Unemployment and Politics. Oxford: Clarendon Press, 1972.

Harris, Jose. Private Lives, public spirit. A social history of Britain 1870-1914. Oxford: Oxford University Press, 1993.

Harris, Jose. "Political Thought and the Welfare State 1870-1914: An Intellectual Framework for British Social Policy." Before Beveridge. Welfare Before the Welfare State. Ed. David 
Gladstone. London: Institute of Economic Affairs, 1999.

Hattam, Victoria. Labour Visions and State Power: The Origins of Business Unionism in the United States. Princeton: Princeton University Press, 1993

Hattersley, Roy. Blood and Fire: the Story of William and Catherine Booth and their Salvation Army. London: Little, Brown, 1999.

Headlam, Stewart Duckworth. The Service of Humanity, and Other Sermons. 1882.

Headlam, Stewart Duckworth. The Sure Foundation. An Address Given Before the Guild of St. Matthew, at the Annual Meeting, 1883. 1883.

Headlam, Stewart Duckworth. The Secular Work of Jesus Christ, his Apostles and the Church of England. London, 1886.

Headlam, Stewart Duckworth. Lessons from the Cross. Addresses given in Oxhey Parish Church on Good Friday, 1886. 1887.

Headlam, Stewart Duckworth. "The Bryant and May Strike." The Church Reformer VII (1888): 171.

Headlam, Stewart Duckworth. "The Lambeth Conference and Socialism." The Church Reformer VII (1888): 180-182.

Headlam, Stewart Duckworth. "The Taxation of Land Values." The Church Reformer VII (1888): 86-87 and 174-76.

Headlam, Stewart Duckworth. "Land Values and How To Tax Them." The Church Reformer VIII (1889): 177-178.

Headlam, Stewart Duckworth. The Guild of St. Matthew, An Appeal to Churchmen. Being a Sermon etc. 1890.

Headlam, Stewart Duckworth. "The Church and Socialism." The Church Reformer IX (1890): 219229.

Headlam, Stewart Duckworth. The London School Board in 1890: An Address, etc.1890.

Headlam, Stewart Duckworth. "Free Education." The Church Reformer X (1891):123.

Headlam, Stewart Duckworth. "The General Election." The Church Reformer XI (1892): 147.

Headlam, Stewart Duckworth. "The Labour Party." The Church Reformer XI (1892): 195-96.

Headlam, Stewart Duckworth. Christian Socialism. A lecture, etc. [Fabian Tract No. 42.]. 1892.

Headlam, Stewart Duckworth. The Laws of Eternal Life, etc. 1897.

Headlam, Stewart Duckworth. The Meaning of the Mass. Five Lectures, With Other Sermons and Addresses. 1905. 
Headlam, Stewart Duckworth. The Socialist's Church.1907.

Headlam, Stewart D. Fabianism and Land Values: A Lecture Delivered to the Fabian Society on October 23rd, 1908. London: English League for the Taxation of Land Values, 1908.

Headlam, Stewart Duckworth. Socialism and Religion. By the Rev. Stewart D. Headlam, the Rev. Percy Dearmer, the Rev. John Clifford, John Woolman. 1908.

Helmstadter, Richard J, and Bernard V. Lightman (eds.). Victorian faith in crisis: essays on continuity and change in nineteenth-century religious belief. Stanford: Stanford University Press, 1990.

Hill, Clive E. Understanding the "Fabian Essays in Socialism" (1889). Studies in British History. Vol. 37. Lewiston, NY et al.: Edwin Mellen Press, 1996.

Hilton, Boyd. The Age of Atonement. The Influence of Evangelicalism on Social and Economic Thought 1785-1865. Oxford et al.: Clarendon, 1988.

Himmelfarb, Gertrude. Poverty and compassion: the moral imagination of the late Victorians. New York: Knopf, 1991.

Hobson, John Atkinson and Albert F. Mummery. The physiology of industry: an exposure of certain fallacies in existing theories of economics. London: 1889.

Hobson, John Atkinson. Problems of Poverty, etc. Social Questions of To-day. London: 1891.

Hopkins, Eric. Working Class Self-Help in Nineteenth-Century England. London et al.: UCL Press, 1995.

Hunt, Tristram. Building Jerusalem: the Rise and Fall of the Victorian City. London: Weidenfeld, Nicolson, 2004.

Ikin, C. W., and Brigid Grafton Green. Hampstead Garden Suburb: Dreams and Realities. London: New Hampstead Garden Suburb Trust, 1990.

Jevons, William Stanley. The Theory of Political Economy. Science Primers. London.: Macmillan, 1878.

Jones, H. Stuart. Victorian Political Thought. British History in Perspective. Basingstoke et al.: Macmillan et al., 2000.

Jones, Peter d'Alroy. The Christian Socialist Revival 1877 - 1914 . Religion, Class, and Social Conscience in Late-Victorian England. Princeton, NJ: Princeton University Press, 1968.

Kahl, Sigrun. "Religious Doctrines and Poor Relief: A Different Causal Pathway". Religion, Class Coalitions and Welfare States. Ed. Philip Manow and Kees van Kersbergen. Cambridge: Cambridge University Press, 2009.

Knowlton, Charles. Fruits of Philosophy. An Essay on the Population Question. New edition, with Notes by George Drysdale and a preface by Charles Bradlaugh and Annie Besant.1877. 
Koven, Seth. "Henrietta Barnett (1851-1936). The (Auto-)Biography of a Late Victorian Marriage." After the Victorians. Ed. Susan Pedersen, and Mandler, Peter. London [u. a.]: Routledge, 1994.

Laybourn, Keith. The Rise of Socialism in Britain. Sutton Studies in Modern British History. Stroud, Gloucestershire: Sutton, 1997.

Leech, Kenneth. "Stewart Headlam 1847-1924 and the Guild of St. Matthew." For Christ and The People. Studies of Four Socialist Priests and Prophets of the Church of England between 1870 and 1930. Ed. Maurice B. Reckitt. London: S. P. C. K., 1968.

Lenard, Mary. Preaching Pity. Studies in Nineteenth-Century British Literature. New York, NY et al.: Peter Lang, 1999.

Lewis, Jane. "The Voluntary Sector in the Mixed Economy of Welfare." Before Beveridge. Welfare Before the Welfare State. Ed. David Gladstone. London: Institute of Economic Affairs, 1999.

Liedtke, Rainer. Jewish Welfare in Hamburg and Manchester, c.1850-1914. Oxford Historical Monographs. Oxford: Clarendon Press, 1998.

Lightman, Bernard. The Origins of Agnosticism: Victorian Unbelief and the Limits of Knowledge. Baltimore: Johns Hopkins University Press, 1987.

Lightman, Bernard V. "Robert Elsmere and the Agnostic Crisis of Faith." Victorian Faith in Crisis. Ed. Richard J. Helmstadter, and Lightman, Bernard V. Stanford: Stanford University Press, 1990.

Lister, Ruth. "Children (but not women) first: New Labour, child welfare and gender." Social Policy 26.2 (2006): 315-335.

Macclelland, Vincent Alan. English Roman Catholics and Higher Education, 1830-1903. Oxford: Clarendon Press, 1973.

Machin, G. I. T. Churches and social issues in twentieth-century Britain. Oxford, Clarendon Press, 1998.

Manow, Philip and Kees van Kersbergen (eds.). Religion, Class Coalitions and Welfare States. Cambridge: Cambridge University Press, 2009.

Marsh, Jan. Back to the Land. London: Quartet, 1982.

Marshall, Alfred. Principles of Economics. London: Macmillan, 1890.

Maurice, Frederick Denison. The Kingdom of Christ, or Hints to a Quaker, Respecting the Principles, Constitution, and Ordnances of the Catholic Church. London: Rivington, 1838.

McBriar, A. M. An Edwardian Mixed Doubles. Oxford: Clarendon Press, 1987.

McLaughlin, Joseph. Writing the Urban Jungle: Reading Empire in London from Doyle to Eliot. 
Charlottesville; London: University Press of Virginia, 2000.

McLeod, Hugh. Religion and Irreligion in Victorian England. Headstart History Papers. Bangor: Headstart History, 1993.

McLeod, Hugh. Religion and Society in England, 1850 - 1914. Social History in Perspective. Basingstoke et al.: Macmillan, 1996.

McLeod, Hugh. Religion and the Working Class in Nineteenth-Century Britain. Studies in Economic and Social History. Houndmills et al.: Macmillan, 1996.

Meacham, Standish. Toynbee Hall and social reform $1880-1914$. The search forcommunity. New Haven, Conn., et al: Yale University Press, 1987.

Meacham, Standish. Regaining Paradise. Englishness and the early garden city movement. New Haven, Conn., et al: Yale University Press, 1999.

Meadowcroft, James. Conceptualizing the State. Oxford Historical Monographs. Oxford et al.: Clarendon Press, 1995.

Mearns, Andrew. The Bitter Cry of Outcast London, etc. London:1883.

Mill, John Stuart. On Liberty. London:1859.

Miller, Mervyn, and A. Stuart Gray. Hampstead Garden Suburb. Chichester: Phillimore, 1992.

Moore, Robert Samuel. Pit-men, Preachers; Politics. The Effects of Methodism in a Durham Mining Community. London: 1974.

More, Thomas. Utopia. Cambridge Texts in the History of Political Thought. Cambridge: Cambridge University Press, 1989.

Morgan, Kimberley J. "The Religious Foundations of work-Family Policies in Western Europe". Religion, Class Coalitions and Welfare States. Ed. Philip Manow and Kees van Kersbergen. Cambridge: Cambridge University Press, 2009.

Morris, Jeremy N. Religion and Urban Change: Croydon 1840-1914. Royal Historical Society Studies in History; 65. Woodbridge: Royal Historical Society [by] Boydell, 1992.

Morris, William. News From Nowhere. Boston: Roberts Brothers, 1890.

Mumm, Susan. Stolen daughters, virgin mothers. Anglican sisterhoods in Victorian Britain. London et al.: Leicester University Press, 1999.

Murdoch, Norman H. Origins of the Salvation Army. Knoxville: University of Tennessee Press, 1995.

Nicholls, David. Deity and Domination. London et al.: Routledge, 1989.

Nicholls, David. The Pluralist State. St Antony's/Macmillan Series. Basingstoke, Hampshire et al.: 
Macmillan et al., 1994.

Norman, Edward R. Church and Society in England, 1770-1970: A Historical Study. Oxford: Clarendon Press, 1976.

Norman, Edward R. The Victorian Christian Socialists. Cambridge et al.: Cambridge University Press, 1987.

O'Brian, Susan. Lay Sisters and Good Mothers: Working Class Women in English Convents 18401910. London: Basil Blackwell, 1990.

Offer, John. An Intellectual History of British Social Policy. Bristol: Policy Press, 2006.

Oldstone-Moore, Christopher. Hugh Price Hughes: Founder of a New Methodism, Conscience of a New Nonconformity. Cardiff: University of Wales Press, 1999.

Orens, John. Stewart Headlam's Radical Anglicanism. Studies in Anglican History. Urbana, Ill. et al.: University of Illinois Press, 2003.

Page, Martin. Britain's unknown genius: an introduction to the life-work of John Mackinnon Robertson. London: South Place Ethical Society, 1984.

Pedersen, Susan, Mandler, Peter and John Clive. After the Victorians. Private conscience and public duty in modern Britain. London: Routledge, 1994.

Pelling, Henry Mathison. A history of British trade unionism. London: Macmillan Press, 1992.

Perkin, Harold. "Individualism versus Collectivism in Nineteenth-Century Britain: A False Antithesis." The Journal of British Studies XVII.1 (1977): 105-118.

Perkins, Daniel, Nelms, Lucy, and Paul Smyth. Beyond Neo-Liberalism: The Social Investment State?. 2004. http://www.bsl.org.au/pdfs/beyond neoliberalism_social_investment_state.pdf

Phillips, Paul T. A Kingdom on Earth. University Park: Pennsylvania State University Press, 1996.

Pickering, William Stuart Frederick. Anglo-Catholicism: A Study in Religious Ambiguity. London: SPCK, 1991.

Pope, Robert. Building Jerusalem: Nonconformity, Labour and the Social Question in Wales, 19061939. Studies in Welsh History. Cardiff: University of Wales Press, 1998.

Pritchard, Ron E. Dickens's England. Stroud: Sutton, 2002.

Prochaska, Frank K. Women and philanthropy in nineteenth-century England. Oxford: Clarendon Press, 1980.

Prochaska, Frank K. "Body and Soul: Bible Nurses and the Poor in Victorian London." Historical Research 60 (1987): 336-348.

Prochaska, Frank K. The Voluntary Impulse: Philanthropy in Modern Britain. Historical 
Handbooks. London: Faber, 1988.

Prochaska; Frank K. "A Mother's Country: Mothers' Meetings and Family Welfare in Britain, 18501950." History 74.242 (1989): 379-99.

Prochaska, Frank K. Christianity and Social Service in Modern Britain: The Disinherited Spirit. Oxford: Oxford University Press, 2006.

Rapp, Dean. "The British Salvation Army, The Early Film Industry and Urban Working Class Adolescents, 1897-1918." Twentieth Century British History 7 (1996): 157-188.

Reed, John Shelton. Glorious Battle. The cultural politics of Victorian Anglo-Catholicism. Nashville [u.a]: Vanderbilt University Press, 1996.

Roberts, Michael J. D. Making English morals. Voluntary association and moral reform in England, 1787 - 1886. Cambridge: Cambridge University Press, 2004.

Robertson, John Mackinnon. Vote for Women. London: A \& H. Bradlaugh-Bonner, no date.

Robertson, John Mackinnon. Equality. A Discourse. London: E. W. Allen, 1886.

Robertson, John Mackinnon. Overpopulation. A Lecture. London: R. Forder, 1890.

Robertson, John Mackinnon. The Fallacy of Saving: A Study in Economics. London: Swan Sonnenschein and Co, 1892.

Robertson, John Mackinnon. The Eight Hours Question. London: Swan Sonnenschein, 1893.

Robertson, John Mackinnon. The Future of Liberalism. Bradford, 1895.

Robertson, John Mackinnon. What has Christianity Done. London: A. \& H. Bradlaugh-Bonner, 1897.

Robertson, John Mackinnon. Culture and Action. A Discourse. London: E. W. Allen, 1897.

Robertson, John Mackinnon. The Church and Education. London: A. \& H. Bradlaugh-Bonner, 1903.

Robertson, John Mackinnon. The Great Budget. London: The Liberal Publication Department, 1910.

Robertson, John Mackinnon. The Meaning of Liberalism. London: Methuen,1912.

Robertson, John Mackinnon. A History of Freethought Ancient and Modern, to the Period of the French Revolution. London: Dawsons, 1969.

Robertson, John Mackinnon. A History of Freethought in the Nineteenth Century. London:

Dawsons, 1969.

Robertson, John Mackinnon. A Short History of Morals. New York: Franklin, 1971. 
Rowntree, B. Seebohm. Poverty. London et al.: Macmillan, 1901.

Ruskin, John. Unto This Last. London: Smith, 1862.

Ruskin, John. Sesame and Lilies. Sunnyside et al.: Allen, 1888.

Sassoon, Anne Showstack. Gramsci and Contemporary Politics: Beyond Pessimism of the Intellect. Routledge Innovations in Political Theory; 4. London: Routledge, 2000.

Scotland, Nigel. Methodism and the Revolt of the Field. A Study of the Methodist Contribution to Agricultural Trade Unionism in East Anglia 1872-96. Gloucester: Sutton, 1981.

Searle, G. R. The Quest for National Efficiency. Berkeley: University of California Press, 1971.

Shackleton, David James (ed.). Women in Industry from seven points of view. By Gertrude M. Tuckwell, Constance Smith, Mary R. Macarthur, Mary Tennant, Nettie Adler, Adelaide M. Anderson, Clementina Black.. London: Duckworth, 1908.

Shaw, George Bernard (ed.). Fabian Essays in Socialism. London: Fabian Society, 1889.

Sidgwick, Henry. The Principles of Political Economy. London: Macmillan, 1883.

Slack, Kathleen M. Henrietta's Dream: a Chronicle of the Hampstead Garden Suburb 1905-1982. London: K.M. Slack, 1982.

Smith, Adam. An Inquiry into the Nature and Causes of the Wealth of Nations: in Two Volumes. London: Strahan, 1776.

Stack, David. The First Darwinian Left. Cheltenham: New Clarion Press, 2003.

Stanley, Henry M. In Darkest Africa, or, The Quest, Rescue and Retreat of Emin, Governor of Equatoria. Microfiches; No. 33556. New York: C. Scribner's Sons; Toronto: Presbyterian News, 1890.

Stelzer, Irwin M. "Christian Socialism in Britain." Public Interest 124 (1996): 2-11.

Stokes, Winifred. „Politics, Pitmen and Primitive Methodism in the South Northumberland Coalfields“, in: The Journal of Regional and Local Studies 21, 2001: 18-28

Tawney, R. H. Religion and the Rise of Capitalism: A Historical Study. Holland Memorial Lectures; 1922. [S.1.]: John Murray, 1926.

Temple, Frederick. Essays and Reviews. London: Longman, Green, Longman, and Roberts, 1860.

Temple, William. Christianity and Social Order. London: Penguin Books, 1942.

Thompson, Edward Palmer. Making of the English Working Class. [S.1.]: V.Gollancz, 1963.

Vicinus, Martha. Independent Women. Work and community for single women; 1850 - 1920. Chicago et al.: University of Chicago Press, 1985. 
Vincent, A. W. "The Poor Law Reports of 1909 and the Social Theory of the Charity Organisation Society." Before Beveridge. Welfare before the Welfare State. Ed. David Gladstone.

London: Institute of Economic Affairs, 1999.

Walker, Pamela J. Pulling the Devil's Kingdom Down: the Salvation Army in Victorian Britain. Berkeley; London: University of California Press, 2001.

Walsh, Barbara Mary. A Social History of Roman Catholic Nuns and Sisters in Nineteenth and Early Twentieth-Century England and Wales: The Veiled Dynamic.: University of Lancaster, 1999.

Walsh, Barbara. Roman Catholic Nuns in England and Wales, 1800-1937: A Social History. Dublin; Portland, OR: Irish Academic Press, 2002.

Watkins, Micky. Henrietta Barnett in Whitechapel. London: Hampstead Garden Suburb Archives Trust, 2005.

Wearmouth, Robert F. Methodism and the Trade Unions. Wesley Historical Society, The Wesley Historical Lecture. Vol. 25, Methodist Conference 1959. London: The Epworth Press, 1959.

Wearmouth, Robert F. Methodism and the working-class movements in England 1800-1850. Clifton, N. J.: Kelley, 1972.

Weinstein, David. Utilitarianism and the New Liberalism. Cambridge: Cambridge University Press, 2007.

Wiener, Martin J. English Culture and the Decline of the Industrial Spirit, 1850-1980. Cambridge, U.K; New York: Cambridge University Press, 1981.

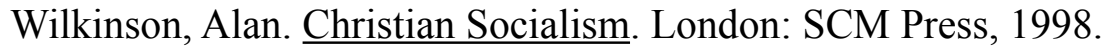

Wilkinson, Alan. "New Labour and Christian Socialism." The Impact of New Labour. Ed. Gerald Taylor. Basingstoke: Macmillan Press, 1999.

Williams, Sarah Charlotte. Religious Belief and Popular Culture: A Study of the South London Borough of Southwark c1880-1939. Oxford: University of Oxford, 1993.

Winston, Diane H. Red-hot and righteous: the urban religion of the Salvation Army. Cambridge, Mass., London: Harvard University Press, 1999.

Woodall, Ann M. What Price the Poor? William Booth, Karl Marx and the London residuum. Aldershot et al.: Ashgate Publications, 2005.

Yates, Nigel. The Oxford Movement and Anglican Ritualism. Historical Association. Vol. 105. London: Historical Association, 1984.

Yates, Nigel. Anglican Ritualism in Victorian Britain, 1830-1910. Oxford: Clarendon, 1999.

Yeo, Stephen and Maurice Benington Reckitt. For Christ and the people. Studies of four socialist 
priests and prophets of the Church of England between 1870 and 1930 : Thomas Hancock, Stewart Headlam, Charles Marson, Conrad Noel. London: SPCK, 1968.

Yeo, Stephen. "A New Life. The Religion of Socialism in Britain 1883-1896." History Workshop Journal 4 (1977): 5-56. 